Szegedi Tudományegyetem

Gazdaságtudományi Kar

Közgazdaságtani Doktori Iskola

Nagy Benedek

\title{
Az optimális szabadalmak elméletének magatartás- gazdaságtani és nemzetközi közgazdasági kiterjesztése
}

Doktori értekezés

Témavezetők:

Prof. Dr. Hámori Balázs CSc Egyetemi tanár Budapesti Corvinus Egyetem
Prof. Dr. Lengyel Imre, MTA doktora Egyetemi tanár Szegedi Tudományegyetem

Szeged

2012 
Eo quod in multa sapientia multa sit indignatio,

Et qui addit scientiam addat et laborem.

(Prédikátor könyve 1:18)

\section{Köszönetnyilvánítás}

Ez a disszertáció, mely most itt fekszik elkészülten, szép formában és tartalommal telve, jóval több időmbe került, mint ahogyan azt a kiinduláskor reméltem, vagy akár terveztem. Valószínüleg még több időbe került volna azonban, hogyha nem kaptam volna segítséget mindazoktól, akiknek most ilyen formán ezt megköszönni igyekszem. Bár számos ember gazdagította a dolgozat tartalmát akarva vagy véletlenül, és sokan rövidítették le az elkészüléshez szükséges időt segítségükkel, vagy növelték meg a rendelkezésre álló szellemi erőforrásokat, mindenki felsorolására nincs módom.

Szakmailag rengeteget köszönhetek Kuba Péternek, aki a matematikai levezetésekben nyújtott felbecsülhetetlen segítséget. A dolgozat matematikai és statisztikai részeiben Szakálné Kanó Izabella és Kovács Péter segítettek kitartóan válaszolva újabb és újabb kérdéseimre. A mikroökonómiai szempontú megjegyzéseivel Mozsár Ferenc emelte a disszertáció színvonalát. Bizonyára mindannyian találnak még mindig olyasmiket, melyekben végül nem hallgattam rájuk. Konzulenseim, Prof. Dr. Hámori Balázs és Prof. Dr. Lengyel Imre fáradhatatlanul ösztönöztek a munkában, és hasznos tanácsokkal láttak el. A disszertáció készültének különböző fázisaiban tartott viták, beszélgetések során sok és hasznos észrevételt, javaslatot kaptam még Bajmócy Zoltántól, Kosztopulos Andreásztól, Vas Zsófiától, Málovics Györgytől, Fenyővári Zsolttól.

Ami a dolgozat elkészítésének idő, erő és lelkesedés-gazdálkodás részét illeti, családom és barátaim kitünő támogatása nélkül bizonyára nehezebben készült volna el a mü. Feleségem és szüleim segítettek át az erő- és lelkesedés-hiányos időszakokon, és Rung András látott el disszertációírás-lélektani tanácsokkal.

Mindannyiótoknak hálás vagyok! A dolgozatban még így is megmaradt hibák miatt csakis magamat vádolhatom. 


\section{Tartalomjegyzék}

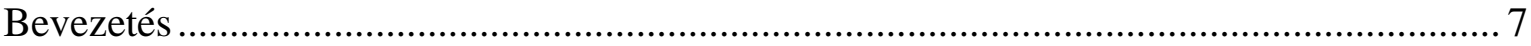

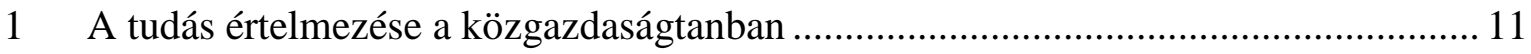

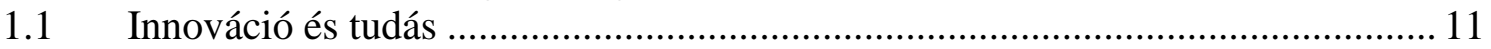

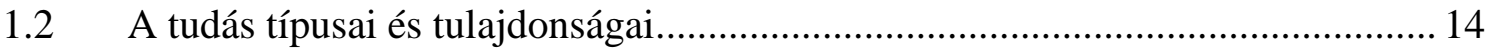

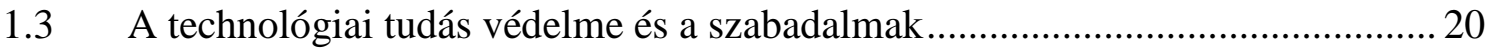

1.4 Az innováció nem modell-szintü megközelítései ................................................. 24

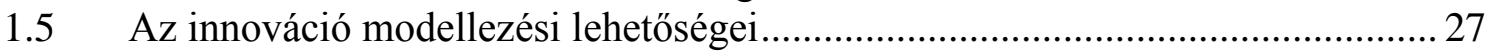

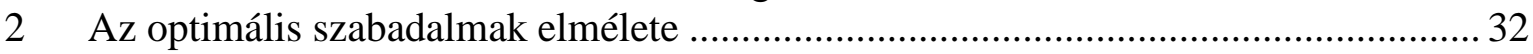

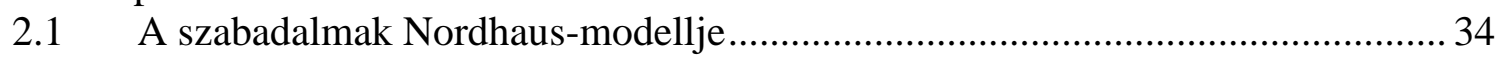

2.2 A modell változatai: új koncepciók és paraméterek ........................................... 39

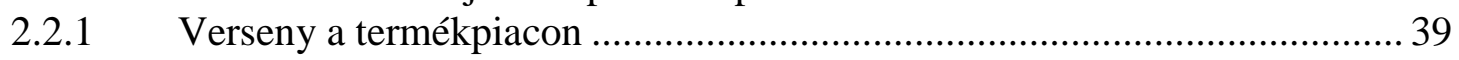

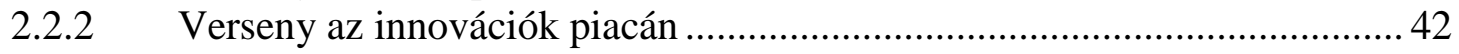

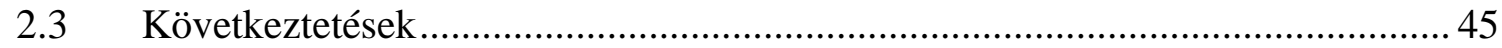

3 A hiperbolikus diszkontálás alkalmazása az optimális szabadalmak elméletére ........ 48

3.1 Az exponenciális diszkontálási modell és alternatívái ........................................50

3.2 Nem-exponenciális diszkontálás a pénzáramok esetében ................................... 60

3.3 A nem-exponenciális diszkontálás alkalmazása az optimális szabadalmak

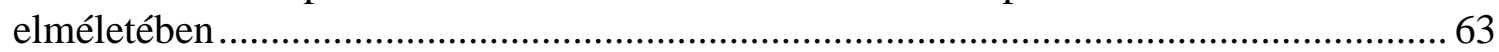

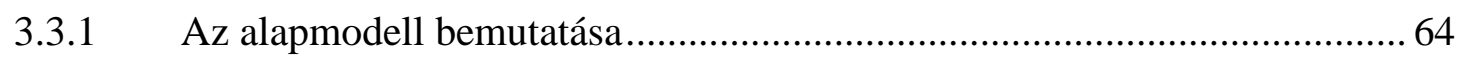

3.3.2 A kvázi-hiperbolikus diszkontálás beillesztése a modellbe ........................ 68

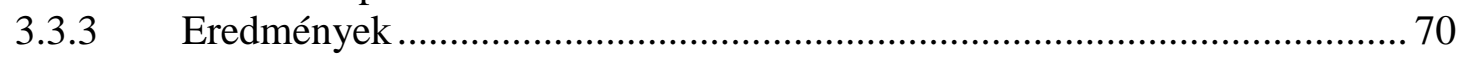

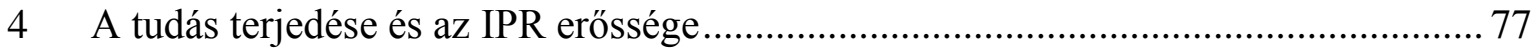

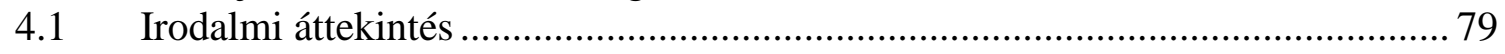

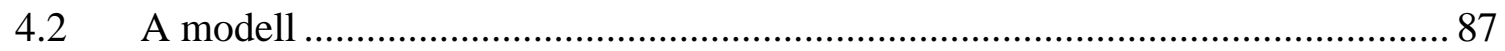

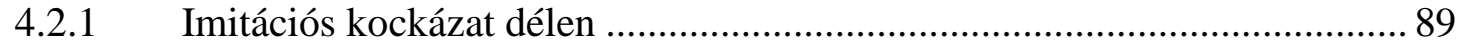

4.2.2 Kettős imitációs kockázat: északon és délen is megjelenhet imitáció......... 92

4.2.3 A relatív IPR védelem ....................................................................... 95

4.2.4 Az IPR szigorodásának iparáganként eltérő hatása .................................. 97

5 A relatív szabadalmi védelmi erősség változás hatása a termékáramlásra................... 100

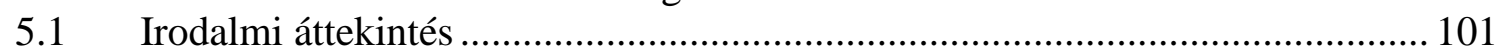

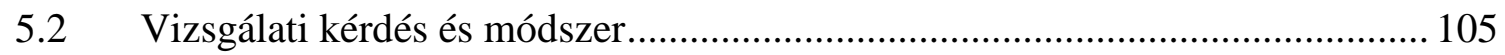

5.2.1 A szellemi tulajdonjog-védelem erősségének mérése ............................. 106

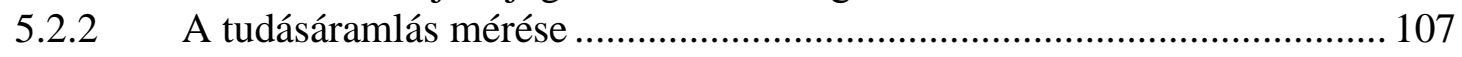

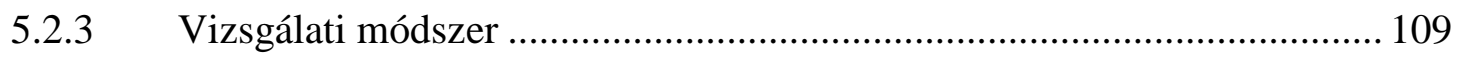

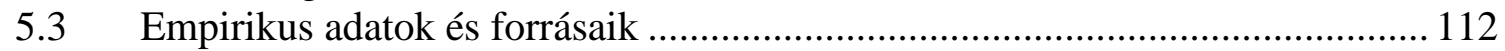

5.3.1 A szabadalmi védelmi erősség relatív változásának mérése .................... 112

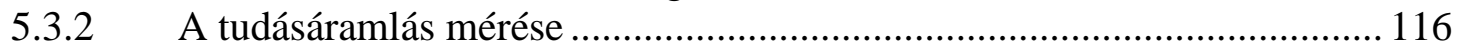

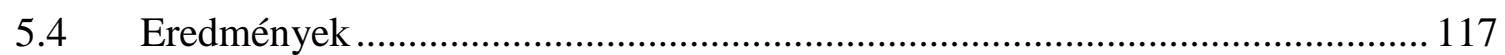

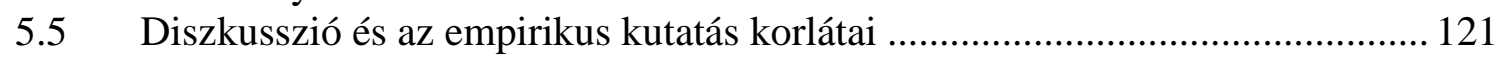

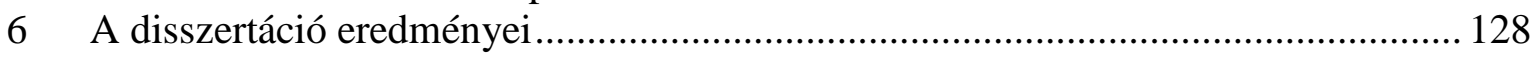

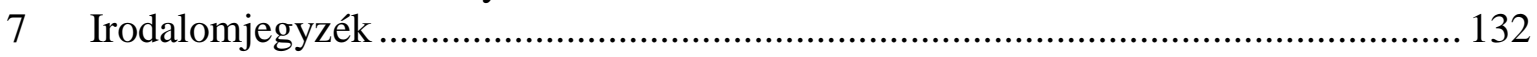

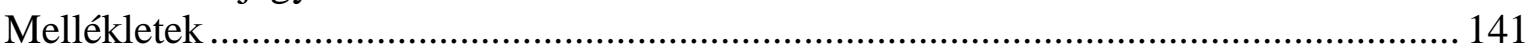




\section{Ábrák jegyzéke}

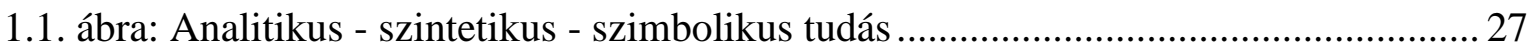

2.1. ábra. A szabadalmak Nordhaus-féle mikroökonómiai modellje ................................ 35

3.1. ábra. Az idő múlásának észlelése az eltelt idő függvényében ......................................55

3.2. ábra. Egy exponenciális és egy kvázi-hiperbolikus diszkontfüggvény ........................58

3.3. ábra. A minimális optimális szabadalmi idő és az optimális szabadalmi idő................ 66

3.4. ábra. Az optimális szabadalmi élettartam hossza exponenciális, illetve kvázihiperbolikus diszkontálás mellett ................................................................................. 72

4.1. ábra. A déli abszorptív kapacitás a termékbonyolultság függvényében........................ 89

4.2. ábra. A déli IPR védelem erősödésének hatása ......................................................... 92

4.3. ábra. A déli és az északi IPR védelem együttes erösödésének hatása .......................... 94

4.4. ábra. Az importőr és az exportőr IPR-védelmi erősségének hatásai ............................ 96

4.5. ábra. Országok abszorptív kapacitásai közti különbségek a modellben....................... 98 


\section{Táblázatok jegyzéke}

3.1a táblázat. $t *$ értéke $\delta_{\text {exp }}=0,952$ esetén (vagyis ha $\left.r_{\exp }=0,05\right) \ldots \ldots \ldots \ldots \ldots \ldots \ldots . .59$

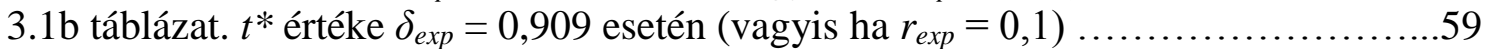

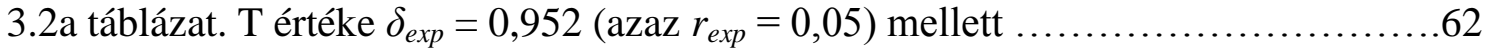

$3.2 \mathrm{~b}$ táblázat. T értéke $\delta_{\exp }=0,909$ (azaz $\left.r_{\text {exp }}=0,1\right)$ mellett ........................62

4.1. táblázat. A kritikus $\hat{G}$ értéke különböző $r_{H}$ és $r_{L}$ mellett ........................97

5.1. táblázat. A különbségek különbsége módszer kimenete .......................111

5.2. táblázat. Az országpárok lehetséges csoportjai a relatív IPR védelmi erősség

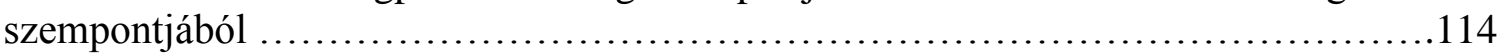

5.3. táblázat. Különbségek különbsége kimeneti tábla: mindkét időszak együtt ........118

5.4. táblázat. Különbségek különbsége kimeneti tábla: az 1. időszak (1997-2002) ......118

5.5. táblázat. Különbségek különbsége kimeneti tábla: a 2. időszak (2002-2007) ......119

5.6. táblázat. Különbségek különbségei fontosabb eredmények .....................120

5.7. táblázat. Szignifikáns DiD értékek száma OECD/WTO tagság szerint ..............122

5.8. táblázat. Szignifikáns DiD értékek száma jövedelemcsoportok szerint .............124

5.9. táblázat. Szignifikáns DiD értékek száma időszakok és iparágak szerinti bontásban 


\section{Bevezetés}

A gazdasági fejlődésben régen azonosított trend a gazdasági tevékenység eltolódása a mezőgazdaságtól az ipar felé, majd az ipar felől a szolgáltatások irányába, és a legutóbbi időkben pedig a tudásintenzív szolgáltatások (vagy éppenséggel termelés) felé. Napjaink tudásalapú gazdaságában a versenyelőny már nem elsősorban a hagyományos tényezőellátottságon múlik, hanem döntően a humán tőke, a tudás tesz versenyképessé vállalatokat, régiókat, országokat. A tudás azonban számos olyan tulajdonsággal rendelkezik, ami miatt máshogy kezelendö, mint a hagyományos erőforrások (nem rivalizáló, nem kimerülő, kumulálódó, rekombinálódó, kontextusfüggő és lokalizált, extern hatások forrása, nehezen transzferálható stb). Előállításának és terjedésének elősegítése ezért a hagyományos piacitól eltérő módszerekkel valósul meg, jellemzően az állam beavatkozásával. Ennek a beavatkozásnak egy megnyilvánulása a szellemi tulajdonjogvédelmi rendszer, melynek különböző „formái” és erőssége különbözőképpen befolyásolja a gazdasági szempontból fontos technológiai tudás előállítását és terjedését. A szabadalmi védelem nem az egyetlen, vagy akár leghatékonyabb módszere a szellemi tulajdon védelmének, vagy elősegítője a technológiai tudás termelődésének, terjedésének. Mégis, míg egyes iparágakban jellemző a nyílt és szabad hozzáférés az új eredményekhez (az open source elv), addig más iparágakban (pl. gyógyszeripar) a szabadalmaknak továbbra is kiemelkedő szerepük van az innovációk elősegítésében és terjedésében. Fritz Machlup már 1958-ban megírta a szabadalom intézményéről szóló tanulmányának konklúziójaként: „ha a szabadalmi rendszer nem létezne, akkor közgazdasági hatásairól meglévő jelenlegi tudásunk birtokában felelőtlenség lenne egy ilyen rendszer felállítását javasolni. Mivel azonban már hosszú ideje rendelkezünk szabadalmi rendszerrel, jelenlegi tudásunk alapján felelőtlenség lenne a megszüntetését javasolni.” (Machlup 1958, 80. o.).

Nyersanyagokban alapvetően szegény országok, mint például Magyarország, számára a tudás, mint erőforrás termelésének és terjedésének elősegítése hatékony eszköze lehet versenyelönyök megszerzésének. Ezért tartom fontosnak ennek a kérdésnek a vizsgálatát.

A kutatásom célja, hogy megvizsgáljam, a szellemi tulajdonjog-védelem, közelebbről a szabadalmi védelem intézménye hogyan befolyásolja a gazdaságilag hasznosítható technológiai tudás termelését az innovátoroknál, illetve az ilyen jellegü tudás terjedését országok között. 
A dolgozatomban alapvetően deduktív, elméleti megközelítést alkalmazok, és közgazdasági modellekből kívánom levonni következtetéseimet. A közgazdasági szakirodalomban a modellek egy széles csoportja foglalkozik a szabadalmi rendszernek a technológiai tudás elöállítására (a modellek kutatás-fejlesztés és innováció formájában jelenítik meg) vagy nemzetközi terjedésére (a modellek ezt termékek, vagy müködő tőke országok közti áramlásaként kezelik) gyakorolt hatásainak vizsgálatával.

A dolgozat alapvetően a neoklasszikus közgazdaságtan talaján áll. Mindazonáltal a neoklasszikus modellt egy endogén módon meghatározódó intézményi változóval bővítem ki, a szabadalmi védelem intézményével. Míg a neoklasszikus közgazdaságtan külső adottságként kezeli a játékszabályokat, melyek mentén a gazdasági szereplőknek optimalizálniuk kell, például a tulajdonjogok intézményét, a dolgozatomban a kérdés éppen az, hogy a szerplők viselkedésére reagálva hogyan lehet kialakítani egy ilyen intézményt. Ennyiben a dolgozat az új intézményi közgazdaságtanból is építkezik.

A tudástermelést- és terjedést legjobban elősegítő intézményi rezsim vizsgálatánál általában normatív megközelítést alkalmazok. A modellek kiterjesztéseként alkalmazott, a kísérleti közgazdaságtan által használt hiperbolikus diszkontálással helyettesítve az exponenciális diszkontálási módszert azonban a dolgozat pozitív megközelítésben vizsgálja meg az intézményi rezsim jóléti hatásait.

A dolgozat része egy empirikus kutatás is, amelyben a tudásterjedés normatív modelljeinek következtetéseire építve nemzetgazdasági szintü adatok elemzésével vizsgálom meg a szellemi tulajdonjogi-rendszerekben bekövetkező változásoknak a hatását a technológia-intenzív termékek nemzetközi áramlására.

A dolgozat kiinduló gondolata, hogy a tudás egy kvázi közjószág, mely esetében nem valósul meg a maga természete szerint a rivalizálás. Ezért amennyiben a kormányzat nem biztosítja, hogy a tudás előállítói az általuk előállított gazdaságilag hasznosítható tudásból származó gazdasági előnyöket élvezhessék, vagyis ha nem oldja meg a nem fizetők kizárását, a potyautas magatartás potenciális megjelenésétől tartva a vállalatok jóval kisebb mennyiségü erőforrást fordítanának új technológiai tudás elöállítására (lényegében innovációra), mint ha ez a kizárhatóság megvalósítható. Az állam által biztosított kizárólagos jogok - szellemi tulajdonjogok -, mint egyfajta lehetséges megoldás ennek a kizárásnak a megvalósítására, ugyanakkor negatív hatásokkal is járnak, amennyiben az eredeti tudástermelőnek monopol pozíciót biztosítanak, és az ezzel járó ideiglenes holtteher-veszteség a társadalom számára éppúgy káros, mintha nem állítódna elő új tudás. 
Így hát feltételezve a szellemi tulajdonjogok intézményét, mint választ a kizárhatóság hiányának problémájára, szükséges megvizsgálni, hogy hogyan biztosítható a tudástermelés optimális mértéke egy gazdaságban. A szabadalmi védelem kettős funkcióval rendelkezik. Egyfelől a potenciális jövőbeli innovátoroknak ígéri az innovációikból származó hasznok elsajátítását, így innovatív erőfeszítésekre késztet. Másfelől pedig, nyitott gazdaságokat feltételezve a szabadalmi védelem a már meglévő innovációk elterjesztését is elősegíti, amennyiben egy már meglévő innováció számára biztosít védelmet egy új piacon. A dolgozatban ezt a két funkcióját vizsgálom meg, és nyújtok hozzájuk kiterjesztéseket.

A dolgozat első része egy elméleti megközelítése a technológiai tudás termelésének és bevezetésének, az innovációnak. Az első fejezetben a különböző elméleti irányzatokat áttekintve határolom körül, hogy mit értek tudás alatt a dolgozat szempontjából. Szükséges a tudás fogalmának operacionalizálása, hiszen csak e mentén értelmezhetők a későbbiekben a tudás termelésére és terjedésére tett kijelentések.

A második fejezetben neoklasszikus alapokon nyugvó modelleken keresztül mutatom be a tudástermelés társadalmi jóléti hatásait. Ugyanakkor az állam által szabályozható szellemi tulajdonjog-védelem, szükebben a szabadalom intézménye, mint endogén változó szerepel a hagyományos neoklasszikus vállalati optimalizáló modellben, ilyen módon közelítve az intézményi közgazdaságtani elemzésekhez. E fejezetben arra keresem a választ, hogy a szellemi tulajdonjogi védelem állam által kialakított és betartatott intézménye hogyan hat a tudástermelésre és az ennek nyomán elöálló jólétre. A fejezet erőteljesen épít W. D. Nordhaus 1967-es „The Optimal Life of a Patent” címü cikkére, mely egy normatív modelljét állítja fel a szabadalmi védelem intézményének és azt vizsgálja meg, hogy a kormányzatnak a modellben szereplő egyetlen intézményi változót, a szabadalmi védelem időtartamának hosszát hogyan kell megállapítania a maximális jólét eléréséhez. Ebből az ötletből (innovációból?) aztán egy egész kutatási irányzata indult ki e normatív modelleknek, a fejezet ezeket kívánja összegezni, csoportosítani és áttekinteni. A bemutatott modellek középpntjában az időtényező áll: hogyan hat a szabadalmi védelem hossza a tudástermelésre, az innovációra és a jólétre.

A harmadik fejezetben a tudástermelés témakörét egy magatartás-gazdaságtani nézőponttal gazdagítom. A szabadalmi élettartam azért fontos az optimális szabadalmak elméletében, mert a szabadalmi védelem miatt előálló jelenbeli piactorzításból eredő holtteher-veszteséget veti össze az időben később megjelenő fogyasztói többletnövekedéssel (valamint a szabadalmi élettartam alatt realizálható profitokkal). Ennek az 
összevetésnek egy fontos eleme a diszkontálás, a különböző időben jelentkező hasznok és költségek jelenbeli értékelése. Még mindig a szabadalmi védelmi rendszer elméleti és intézményi közgazdaságtani megközelítésénél maradva, a hiperbolikus diszkontálás mint leíró modell következményeit kívánom alkalmazni az optimális szabadalmak elméletében. Ebben a részben azt vizsgálom meg, hogy a modellalkotásnál használt exponenciális diszkontálási modellt a deskriptíven nagyobb erejü (kvázi)hiperbolikus diszkontálási modellekkel helyettesítve mennyiben módosulnak a normatív modellek jóléti következtetései.

A dolgozat második részében azt vizsgálom meg, hogy miként hat a szellemi tulajdonjogi védelmi rendszer erőssége a tudás nemzetközi terjedésére. Először a negyedik fejezetben szintén modelleken keresztül vizsgálom meg az összefüggéseket. A bemutatott modellek a nemzetgazdaságok közötti tudásáramlásnak egy lehetséges operacionalizálását adják meg: az új technológiai tudás technológia-intenzív termékek illetve szolgáltatások áramlásával, illetve tudás-intenzív müködőtőke-áramlással mozoghat országhatárokon át. Áttekintem, hogy a különböző makroökonómiai modellek segítségével milyen összefüggések találhatók a termékek nemzetközi forgalma formájában megvalósuló tudásáramlás és a szellemi tulajdonjog-védelem erössége között. Az exportálási döntést mikroszinten vizsgálva egy modell segítségével mutatom meg, hogyan hat a termékek nemzetközi áramlására az, hogy a kereskedelmi partnerek szabadalmi-védelmi szabályozásai erösségben egymáshoz képest hogyan változnak.

A második rész tartalmaz egy empirikus vizsgálatot is. Az empirikus kutatás a negyedik fejezet modellje által megvilágított összefüggéseket kívánja tesztelni. Korábbi kutatások során statisztikai összefüggést találtak egy ország szellemi tulajdonjogi rendszerének erőssége, szigorúsága, illetve az országba beáramló technológia-intenzív termékek mennyisége között. Az ötödik fejezetben empirikusan vizsgálom meg, hogy befolyásolja-e az x országba y országból érkezö termékimport alakulását x ország szellemi tulajdonjog-védelmi rendszere erösségének y országéhoz képesti relativ változása. Regressziós modell helyett a „különbségek különbsége” statisztikai módszer használatával vizsgálom az összefüggéseket. A kereskedelmi partnerekből csoportok képezhetőek például a mentén, hogy az importőr országban a szabadalmi védelem erősebbé vagy gyengébbé vált az exportőr szabadalmi védelméhez képest. A következtetés újfent az, hogy a kormányzati beavatkozás a szabályozási környezetbe elősegítheti, vagy éppen hátráltathatja a tudásterjedést. 


\section{A tudás értelmezése a közgazdaságtanban}

Mindannyian ismerjük a mondást: „a tudás hatalom”. A közgazdasági irodalomban azonban a tudás leginkább olyan kifejezésekkel kapcsolódik össze, mint növekedés, jólét, profit. Az innováció, gazdaságilag hasznosítható új tudás előállítása és alkalmazása a közgazdaságtanban régóta felismert és elismert módja vállalati szinten a piaci erő megszerzésének és többletprofit elérésének, valamint hosszú távú fennmaradásnak, makroszinten pedig a társadalmi jólétnövekedésnek, és általában véve a gazdasági növekedésnek.

A fejezet első részében a teljesség igénye nélkül az innováció néhány definícióját gyüjtöm össze, és kiemelem belőlük azt a közös tényezőt, amely disszertációm szempontjából összeköti őket. A második részben az innovációs definíciókban implicite meghúzódó, és azok alapját képező tudás, mint speciális terméket állítom a középpontba. Összegyüjtve néhány különleges tulajdonságát, azt igyekszem bemutatni, hogy máshogyan kezelendő, mint a közgazdaságtan hagyományos tárgyát képező javak. A harmadik alfejezteben néhány lehetséges választ mutatot be a tudás korábban említett különleges tulajdonságai által felvetett problémák kezelésére, kiemelve ezek közül a szabadalmi védelem intézményét. A negyedik alfejezetben, lehatárolandó a disszertációban később alkalmazandó gondolati körtől azkat a meglehetősen nagy hagyományokkal és kiterjedt szakirodalommal rendelkező irányzatokat mutatom be röviden, melyek tudásteremtéssel és innovációval foglalkoznak ugyan, de nem matematizált vagy modellekben gondolkodó módon. A fejezet végén az ötödik részben pedig azokat az irányzatokat tekintem át, melyek modelleket használva mutatják be az innováció és a technikai fejlődés fontosságát, gazdasági növekedésben betöltött fontos szerepét. A disszertáció későbbi részeiben magam is ilyen módon vizsgálom meg a tudás termelésének és terjedésének egyes problémáit.

\subsection{Innováció és tudás}

Az innováció egy meglehetősen multidiszciplináris kifejezés, és egyetlen önálló diszciplína sem tudja önmagában az innovációt minden részletére és aspektusára vonatkozóan tárgyalni, még kevésbé definiálni.

Az innovációs irodalom egyik legfontosabb korai alakja, Joseph Alois Schumpeter. Az ő innovációs elméletét foglalja össze röviden Witt (2002) az alábbi módon: „A változást, mely endogén módon következik be a gazdaságban a vállalkozók innovatív 
tevékenysége hozza létre; ők az egyedüli szereplők, akik képesek meglévő erőforrások új kombinációit előállítani vagy szervezeti formákat megváltoztatni” (Witt 2002, 13. o.) Az innováció tehát nem más, mint meglévő erőforrások új kombinációja, vagy szervezeti formák új összetétele. A schumpeteri innovációk egy teremtő romboláson (creative destruction) keresztül folyamatosan formálják át a gazdaságot. Új vállalkozók jelennek meg új innovációkkal, a piac pedig a maga természete szerint a verseny körülményei között elvégzi a szelekciót: versenyelőnyre tesz szert és profitot érhet el a leghasznosabb innovációt bevezető vállalat, azok a vállalatok, akik innovációi kevésbé hasznosak, vagy éppen meghaldottak, hátrányba kerülnek a versenyben, alacsonyabb profitot érhetnek el, vagy akár csődbe is mehetnek. Az egymást követő innovációk sora egy bizonytalansággal terhes, nem egyensúlyi piaci helyzeteken keresztül lezajló evolúciós folyamat. Az új tudáselemek a régebbieken építkezve egy történelmileg meghatározott pályán haladnak elöre: a technológiai fejlődés útfüggőséget mutat.

Ács Zoltán és Varga Attila egy az innovációs rendszerek irányzatának gondolati keretén belüli definíciót ad az innovációra: „A technológiai innováció lényegében új tudás létrehozása, vagy már létező tudáselemek kombinálása új módokon, és ezek transzformációja gazdaságilag szignifikáns termékekbe vagy gyártási folyamatokba" (Ács - Varga 2000, 33. o.). Az innovációs folyamat részei a tudományos ismeretek bővülése (itt főleg természettudományos ismeretekre gondolnak, a világ törvényszerüségeiről alkotott tudásunk halmazának növekedése értendő alatta), a technológia kifejlesztése (a meglévő tudásunk alkalmazása valamilyen gyakorlati célt szolgáló technikai módszer megalkotására), és a termék kidolgozása és piacra vitele (a termék a meglévő technológia felhasználása egy konkrét funkció elvégzésére alkalmas fizikai tárgy megalkotására) (Varga 2006). Ez a megközelítés nagy hangsúlyt fektet arra, hogy az innovációk egy sokszereplős, komplex és interaktív rendszerben jönnek létre, ahol a tudásteremtéssel párhuzamosan tudásterjedést is magába foglal az innovációs folyamat.

Az innováció egy olyan folyamat, amelynek során új tudás, vagy régi tudás új kombinációi öltenek testet termékekben vagy termelési folyamatokban, és jelennek meg a piacon (Monore - Taylor 2010, 7. o.). Az innováció fontos része tehát a már meglévő tudásbázis, mint input, és a képesség új tudás előállítására vagy befogadására. A hosszú távú versenyelőnyök kulcsa a vállalati tudásbázis bővítésének képessége.

Rogers (2003) megfogalmazása szerint az innováció „,egy ötlet, gyakorlat vagy tárgy, amelyet egy személy vagy egyéb felhasználó szervezeti egység újként érzékel” (12. o.). Ez a definíció tartalmazza azt az elemet, hogy az innováció valami újdonság az alkalmazó 
szempontjából. Ugyanakkor expliciten is kifejti, hogy ahhoz, hogy innovációról beszélhessünk, nem szükséges objektív újdonságnak lennie. Elegendö, hogy a felhasználó számára eddig ismeretlen, nem alkalmazott dologról legyen szó Az innováció szokásos definíciói általában ennél szükebb értelemben határozzák meg az innovációt.

Fontos különválasztani az invenciót az innovációtól (Szabó 2012). Az invenció valami újdonságnak a feltalálása, míg az innováció pedig ennek üzleti alkalmazása. Az invenció és az innováció elválhatnak egymástól időben (sokszor hosszú időnek kell eltelnie, mire egy technikai újításból piacra vihető termék lesz), vagy alanyában (egészen más képzettség szükséges a feltaláláshoz, mint az üzlethez. Aki rendelkezik a megfelelő technikai szaktudással, amelynek segítségével a jelenlegi technikai szintet meghaladó termékeket vagy eljárásokat tud megalkotni, egyáltalán nem biztos, hogy rendelkezik a megfelelő gazdasági ismeretekkel vagy vállalkozói készségekkel ahhoz, hogy találmányából profitot szerezzen). Inzelt (2011) egy magyarországi e-felmérésben számos olyan vállalatot talál, amelyek rendelkeznek saját szabadalommal, vagyis invencióval, viszont nem innovatívak, nem vezettek be újításokat.

Innovációt több területen is bevezethetnek a vállalatok. Schumpeter még az innovációknak öt típusát említi: új termék, új termelési módszer, új beszerzési források, új piacok kihasználásának felfedezése és új módszerek a gazdasági tevékenység szervezésére (Witt 2002). A jelenleg mértékadó, az OECD által kidolgozott Oslo Kézikönyv innovációdefiníciója szerint „Az innováció (1) új, vagy jelentősen javított termék (áru vagy szolgáltatás), (2) új eljárás, (3) új marketing-módszer, vagy (4) új szervezési-szervezeti módszer bevezetése az üzleti gyakorlatban, a munkahelyi szervezetben vagy a külső kapcsolatokban.” (OECD 2005, 46. o., sorszámozás tőlem). A kézikönyv szerint az innovációnak egy minimum-követelménye, hogy az innovációt végrehajtó vállalat számára újdonságról, vagy jelentős javításról legyen szó, és fontos eleme, hogy valóban be legyen vezetve, alkalmazásba legyen véve.

Az általam felhasznált és kiterjesztett modellek azonban ennél szükebben értelmezik az innovációt, és ezek közül csupán az első kettőre koncentrálnak. Ezt a kétfajta innovációt összefoglaló néven technológiai innovációnak hívjuk (OECD 2005, Inzelt 2011).

Mint ahogyan az összes fenti definícióból kitünik, az innovációnak központi eleme a tudás, az új tudás megszerzése, vagy meglévő tudás új módokon való összekombinálása. „Az innováció által új tudás keletkezik és terjed szét, mely kiterjeszti a gazdaság új termékeket hatékonyabb müködési módszereket kifejlesztő potenciálját.” (OECD 2005, 33. o.) A technológiai innováció két fajtájához is különféle tudás köthető. A termék-innovációt 
értelmezhetjük úgy, mint arra vonatkozó tudást, hogy mit termeljünk: milyen új termékeket hozhatunk létre, vagy milyen fejlesztéseket hajthatunk végre a már meglévő termékeken. A folyamat-innováció ezzel szemben olyan tudás, ami arra vonatkozik, hogy hogyan termeljük a már meglévő, az új, vagy a továbbfejlesztett termékeket. Ezeket a vállalati innováció során felhasznált tudásokat nevezhetjük technológiai tudásnak, szemben a tudományos tudással. Míg a tudomány célja, hogy megértse a természetet, és e célból tudást állít elő, addig a technológia célja, hogy befolyásolja a természetet, amely célból mesterséges eszközöket (artifact) állít elö (Faulkner 1994). Az innovációk kapcsán nem akármilyen fajta, vagy általános értelemben vett tudásról, hanem technológiai tudásról van szó. Az innováció a technológiai tudás megváltozása.

A következő alfejezet ennek a technológiai tudásnak a közgazdaságilag fontos tulajdonságait tekinti át.

\subsection{A tudás típusai és tulajdonságai}

A (gazdaságilag hasznosítható) tudás rendelkezik bizonyos tulajdonságokkal, melyek megkülönböztetik más egyéb, hagyományos termékektől vagy termelési eröforrásoktól. Először azonban magát a tudást kell megkülönböztetnünk az adattól és az információtól. Ezt a klasszikus hármas bontást illetve értelmezést használja Boisot - Canals (2004). Az adat „a világ fizikai állapotában észrevehető és megkülönböztethető különbségekből származik" (Boisot - Canals 2004, 46. o.). Az embereket a mindennapi életük során folyamatosan érik külvilágból származó ingerek, de nem minden inger lesz azonban adat, mert nem minden inger különböztethető meg minden ember számára. Disszertációm későbbi témáját előrevetítve számomra például egy adat az, hogy Algéria 1995-ben Ausztráliából 4297 dollár értékben importált high-tech termékeket. Az információ az adatokban rejlö értelmes összefüggés. Az adatból úgy lesz információ, hogy az emberek átszűrik az általuk érzékelt adatokat a már meglévő tudásukon, és megpróbálják kinyerni belőle az értelmet. Az információ tehát nem más, mint értelmezett adat. Ugyanazt az adatot különböző emberek különbözőképpen értelmezhetik, tehát egy adat más-más ember számára más-más információt hordozhat. Az információ már kontextusfüggő. Ugyanaz az adat valaki számára lehet életmentően hasznos, más számára értéktelen, megint más számára akár teljességgel érthetetlen - éppen ez adja a titkosítás, a kódolás létjogosultságát. Tovább füzve a fenti példát, az említett adat úgy lesz számomra információ, hogyha megtudom, hogy mely termékek számítanak egyáltalán high-technek, 
vagy azt, hogy mekkora volt Algéria és Ausztrália között a high-tech termékforgalom 1996-ban (154819 dollár) vagy 1997-ben (51787 dollár). Az adat immár információ, informál valamiről, üzen valamit (Davenport - Prusak 2001). A tudás pedig a cselekvő által birtokolt várakozások egy halmaza: ezen várakozások alapján fogja döntéseit meghozni. A cselekvő várakozásait a beérkező új információk folyamatosan módosítják, az adatok megfelelő értelmezésével a cselekvő a döntéshozatalban jobb eredményeket érhet el. A nagyobb tudás tehát jobb várható eredmény. Az egyes országok közötti termékáramlásra vonatkozó információk alapján lehetségessé válik számomra feltételezések tesztelése és következtetések levonása. A felépített elmélet (tudás) alapján pedig végezhetőek akár jövőre vonatkozó predikciók. A tudás azonban sosem teljes, a döntéseinket valószínűségi eloszlások alapján hozzuk meg és ezek az eloszlások időben változnak. Az információk folyton arra késztetik a döntéshozót, hogy ezekről a releváns valószínűségi eloszlásokról való várakozását módosítsa. ${ }^{1}$

A közgazdasági elmélet néha egyenlőségjelet tesz az információ és a tudás közé. Amikor a neoklasszikus közgazdaságtan a tudásról beszél, azt többnyire ebben az értelemben teszi. Ebben az értelemben használja a tudást például akkor, amikor a fogyasztók/vállalatok „hiánytalan tudásáról”, vagyis szinonimákkal fogalmazva tökéletes informáltságáról beszél. A neoklasszikus közgazdaságtan a gazdasági történéseket a statikus egyensúlyi elemzés keretein belül vizsgálja. A fogyasztók és vállalatok a döntéseiket a piac által szolgáltatott információk alapján hozzák meg. A piac az árjelzések mechanizmusával valójában egy információ-szolgáltató rendszer, és a piac által szolgáltatott információkhoz a gazdasági szereplők azonnal és hibátlanul képesek a modell szerint alkalmazkodni. A piac pedig az egyes egyének döntéseiből azonnal előállítja a többiek számára releváns új információkat, amelyek a működési mechanizmusból eredően mindenki számára költségmentesen rendelkezésre állnak. Vagyis a neoklasszikus modell gazdasági alanyainak „tudása” leginkább a társadalom egészének (illetve a többiek) preferenciájának, a termelésben leghatékonyabb technológiáknak valamint a modell és a döntéshozás szempontjából fontos paramétereknek a mindenkori ismeretét jelenti.

\footnotetext{
${ }^{1}$ A tudást ilyen értelemben használja például a játékelmélet, amikor a játékosok aszimmetrikus tudásáról vagy közös tudásáról beszél. Az ismételt játékokban előfordul, hogy az újabb és újabb játszmák eredményei, mint információk módosítják a játékosok tudását, és amit eleinte kizárólag az egyik vagy néhány játékos tudott, az közös tudássá válhat, vagy a közös tudásból lehet egyéni tudás.
} 
Hayek - és az osztrák iskola általában - felvetnek egy fontos kiegészítést még az ilyen értelemben vett tudás kapcsán is: Egyrészt, hogy „,a tudás, amely az egyensúlyi állapotot meghatározza, az egyensúlyhoz vezető folyamat közben alakul ki” (Boettke 2002, 267. o.), vagyis nem exogén adottság a modell szempontjából, hanem inkább egy endogén változó. Másrészt, hogy „... tudás az összes körülményre vonatkozóan, amelyet fel kell használnunk, sosem létezik koncentrált formában, hanem szétszórt, részleges és gyakorta egymásnak ellentmondó darabkák formájában, amit a különálló individumok birtokolnak” (Hayek 1945, 520. o.). Hayek tehát hangsúlyozza, hogy az egyes gazdasági szereplők speciális és kontextusfüggő tudása egyáltalán nem biztos, hogy mindenki számára ismert. Hayek külön megemlíti a tudományos tudást, és azt mondja róla, hogy annak a kezelése kisebb probléma, hiszen a releváns (hasznosításra érdemes, legtermékenyebb, legértékesebb?) tudás birtokosait könnyebb összegyüjteni, mint a fentebb említett tudásdarabkák birtokosait. Amikor azonban a tudás-társadalom alapjaként értelmezett tudásról beszélünk, akkor nyilvánvalóan nem ezekre az egyébként valóban a mindennapi döntésekhez fontos tudás-töredékekre - valójában információkra - gondolunk, igazából nem ezeknek a termelése és terjesztése állít minket nehéz helyzet elé. Az innovációk nem erre a fajta tudásra alapoznak, hanem a gyártott termékekkel, a termelési eljárással, a vállalat szervezeti felépítésével kapcsolatos technológiai tudásra.

Disszertációm további tárgya tehát a technológiai tudás, mely számos olyan tulajdonsággal rendelkezik, ami megkülönbözteti más, hagyományos termékektől, illetve szolgáltatásoktól. Az alábbiakban szeretném végigtekinteni ezeket a fontos tulajdonságait. A tudás lehet explicit, vagy rejtett, képes kumulálódni és rekombinálódni, fontos pozitív és negatív extern hatások forrása, nehezen mérhető és értékelhető, valamint kváziközjószágként jellemző rá a rivalizálás és a kizárhatóság hiánya.

\section{Explicit és rejtett tudás}

A technológiai tudás megjelenési formája szerint lehet explicit, kifejezett vagy kodifikált tudás, illetve lehet tacit, hallgatólagos vagy rejtett tudás. A hallgatólagos tudás először Polányi Mihály munkásságában jelenik meg, aki ezt írja róla: „többet tudunk, mint amit szavakba tudunk önteni” (Polányi 1966, 4. o.). Az explicit tudás esetében a tudást le lehet írni, rajzolni, hang- vagy képfelvételt lehet róla készíteni, és ez a tudás eredeti birtokosától elválasztva hordozza magában a tudást, ami térben és időben alacsony 
költséggel átvihető. Az explicit tudás könnyen kommunikálható. A hallgatólagos tudással az a legnagyobb probléma, hogy nehezen adható át, nehezen transzferálható személyek vagy vállalatok között. Átadása jóval nehezebb és költségesebb, mint az explicit tudásé, mert a tudás eredeti birtokosának aktív közremüködése, akár időleges jelenléte szükséges hozzá. ${ }^{2}$

A vállalatok által használt technológiai tudás erősen kontextusfüggő, ezért lokális (Foray 2004, 17. o.). Érvényes ez az explicit tudásra is, de sokkal erősebben a tacit tudásra. Az a tudás, ami egy helyen az adott körülmények között és az adott intézményi környezetben értékes, másutt nem biztos, hogy használható vagy értékes. A tudás átvitele egyik helyről a másikra ennél fogva nagyobb akadályokba ütközhet, nagyobb költségekkel járhat, mint akár a tőkejavak, akár a munka vagy más termelési tényezők esetében. A transzferáláshoz megfelelő intézményi, kulturális és kognitív távolságra van szükség (Lengyel - Fenyővári - Nagy 2012).

\section{A tudás kumulatív és rekombinatív tulajdonsága}

A tudás képes kumulálódni, vagyis felhalmozható. Mint a korábbi alfejezetben az innováció definícióinál láttuk, a tudásteremtés magába foglalja már meglévő tudáselemek új kombinációit is. A már meglévő tudáselemek közötti kiegészítő viszony fontos meghatározója a jövőbeli innovációknak. „Ha messzebbre láttam volna, csak azért volt, mert óriások vállán álltam” - idézi Sir Isaac Newtont Scotchmer (1991, 29. o.) a szekvenciális innovációkról szóló cikkében.

Az előzővel szorosan összefüggő tulajdonsága a tudásnak a rekombinálódási képessége. A tudás ugyanis helyettesíthető (fungible), abban az értelemben, hogy sokféle különböző irányban lehet egy adott tudáselemböl kiindulni (Antonelli 2004). A tudás kumulálódó és rekombinálódó tulajdonságai adják meg a jövőbeli kutatás és új tudás előállításának lehetőségét és irányait.

A tudás alacsony reprodukciós költségekkel átvihető más területekre (Nordhaus 1967). Ennek nagy jelentősége van az imént említett rekombinálódó és kumulatív tulajdonságai miatt. Mindezekből fontos további tulajdonságai származnak. ${ }^{3}$

\footnotetext{
${ }^{2}$ Bizonyos kritikák azonban a tudásnak az egyik meghatározó tényezőjéül éppen a kommunikálhatóságot jelölik meg, ami kizárja, hogy a hallgatólagos tudást is tudásnak tekintsük. Alternatív megoldásként a Polányi által hallgatólagos tudásnak nevezett jelenséget hívhatnánk képességnek vagy képzettségnek (Schreyögg, 2002).

${ }^{3}$ Ezen kedvező tulajdonságainak természetesen gátat szabhat az előzőleg említett kontextusfüggőség. A rekombinálódás és az alacsony költséggel való reprodukció a tudás tacit és erősen kontextusfüggő részénél nem, vagy csak kevésbé érvényesülhet.
} 


\section{A tudás extern hatások forrása}

A tudás fontos extern hatások forrása lehet. A pozitív oldalon azt figyelhetjük meg, hogy az egyes vállalatok által folytatott kutatások, illetve az azok nyomán előálló tudás növeli a más vállalatoknál folytatott kutatások hatékonyságát (Ács - Varga 2000). Ebben az értelemben a tudásból származó pozitív externhatások hasonlatosak a hálózati externáliákhoz (Katz - Shapiro 1985). Mivel az új tudáselemek jövőbeli kutatási irányok egész sorát nyithatják meg, ezért értékük annál nagyobb, minél többen használják őket.

A hagyományos erőforrásaink esetében a cél az optimális felhasználás, a meglévő készletekkel való minél jobb gazdálkodás. A tudás azonban a rekombinálódás és a kumulálódás kapcsán növekvő hozadékot biztosít, és gyakorlatilag kimeríthetetlen erőforrás. A tudástermelés esetében nem arról van szó, hogy egy rögzített mennyiségü össztudás egyre nagyobb része válik ismertté. Az új tudás nem csökkenti, hanem kiterjeszti a jövőbeli felfedezési lehetőségeket: ${ }^{4}$ minél nagyobb a tudás szigete, annál hosszabb a tudatlanság partvonala.

Az új tudásnak azonban negatív extern hatásai is vannak. A tudás idővel veszít értékéből. Nevezhetnénk ezt akár amortizálódásnak is, bár ez esetben az érték időbeni csökkenése nem az erőforrás fizikai értelemben vett elhasználódásából, elkopásából származik. Rogers (2003) az innovációk terjedéséről írott könyvében bemutatja, hogy hogyan jut el egy innováció a korai adoptálóktól a késői adaptálókig. Ahogy az újítás egyre elterjedtebb lesz, ahogyan mindenki számára ismerté válik egy új termék vagy termelési eljárás, a közös tudásnak a gazdasági értéke egyre csökken: a tudás amortizálódik. A tudás amortizálódásának másik lehetősége az, amikor a meglévő tudás bázisán történő új tudás előállításának állandó körforgásában az új, magasabb rendủ tudás a korábbit feleslegessé teszi: ez a minőségi lépcsők elmélete a kutatás-fejlesztésben (Grossman - Helpman 1991a). A tudás értéktelenedésének egy másik formája a felejtés: a tartósan nem használt tudás elvész.

\section{A tudás nehezen mérhető és értékelhető}

Nincs olyan általános mértékegység (mint az információ esetében a bit), amely a tudás különböző dimenzióit közös nevezöre tudná hozni, és így összehasonlíthatóvá, összemérhetővé tudná tenni. Ezzel párhuzamosan a tudás értékét a későbbiekben is nehéz

\footnotetext{
${ }^{4}$ Az útfüggőség miatt valójában lehet, hogy egy-egy új felfedezés vagy innováció egy technológiai pályára késztet. Az új tudás kinyit ugyan néhány ajtót, másokat viszont bezár, vagy inkább elfordul tölük.
} 
meghatározni, hiszen egy több tudás-darabból álló új tudásegység előállításánál nehéz meghatározni, hogy melyik alkotóelem pontosan mekkora résszel járult hozzá az új egység előállásához. Egy alapkutatásbeli eredményt értékben nehéz összevetni egy alkalmazott kutatásbeli eredménnyel.

Ex ante egy kutatási eredményről nehéz eldönteni, hogy mekkora tudás-értéket képvisel, ezt nagyban befolyásolja az, hogy milyen későbbi rekombinálódási potenciállal bír. Ahhoz, hogy egy potenciális vásárló egy tudás-elemről eldönthesse, hogy megvásárolja-e és hogy mennyit adjon érte, tudnia kell, hogy mit vásárol. Ha azonban már tudja, akkor nem áll érdekében fizetni érte.

\section{A tudásra jellemző a rivalizálás és a kizárhatóság hiánya}

A tudás ezen különleges tulajdonságával áll összefüggésben két, a későbbiek szempontjából döntő fontosságú tulajdonsága: a rivalizálás és a kizárhatóság hiánya.

A tudás esetében, ha egyszer már előállt egy új tudás-elem, akkor a gazdasági felhasználása során nincsen rivalizálás. A rivalizálás hiánya (non-rivalry) a tudásnak, mint egy gazdasági döntés tárgyának az a tulajdonsága, hogy ha valaki felhasználja valamilyen célra a már meglévő tudást, ezzel senki más lehetőségeit nem korlátozza, hogy ugyanazt a tudást felhasználják. Romer megkülönböztet a tudáselemek között is olyanokat, amelyek emberhez kötöttek (mint az a tudás, hogy valaki képes összeadni), és olyanokat, melyek nem emberhez kötöttek (mint például egy design). Az előbbit rivalizálónak nevezi, mivel ha az ember éppen összead, akkor közben nemigen tud mással foglalkozni, míg az utóbbi kategória nála a tisztán nem rivalizáló, mert ugyanazt a design-t egyidejűleg sok helyen és sok mindenki felhasználhatja (Romer 1990, S74. o.). A rivalizálás hiánya, mint korábban bemutattam, csak technikai értelemben valósul meg, gazdasági értelemben létezik rivalizálás a tudás felhasználói között. Ha más is tudja azt, amit én, attól én még ugyanúgy tudhatom, de a tudásomnak az értéke csökkenhet ezáltal.

A kizárhatóság hiánya (non-excludability) azt jelenti, hogy az új tudás előállítói csak kisebb-nagyobb költségek árán tudnának az általuk létrehozott új tudásért ellenértéket szedni mindazoktól, akik használni akarják. A tudás bizonyos elemei esetében a kizárhatóság legalábbis részlegesen megoldható. A tudás nem kodifikált, rejtett része képes lehet megvalósítani a kizárhatóságot, amennyiben speciális know-how nélkül a tudás nem transzferálható a gazdasági szereplők között. Az információ esetében ilyen módszer például a titkosítás, kódolás. A kizárhatóság megteremtésének egy másik lehetséges útja a jogi út: amikor is jogi korlátozásokat vezetünk be arra, hogy ki használhatja fel a tudást és ki nem. Erre a célra születtek meg a tudás (legalább részben) magántulajdonná tevését szolgáló különböző szellemi tulajdonjogi intézmények. 


\subsection{A technológiai tudás védelme és a szabadalmak}

A technológiai tudás nem rivalizáló jellegéből adódóan nem érdemes kizárni a használatából senkit, a nem kizáró természete miatt pedig gyakorta nem lehetséges kizárni senkit (Stiglitz 1999). A nem rivalizáló tulajdonságból eredő pozitív externhatások illetve az alacsony reprodukciós költségek miatt a tudásnak ${ }^{5}$, ha már egyszer előállt, zérus áron hozzáférhetővé kellene válnia mindenki számára. A kizárhatóság bármilyen megvalósítása meggátolná a tudás minél szélesebb körü, minél megtermékenyítőbb felhasználását. A kizárhatóság hiánya azonban potyautas magatartást szülne: mindenki úgy akarná használni a tudást, hogy ne kelljen fizetnie érte. A tudás előállítása azonban az esetek nagy részében költségekkel jár. Ha a költségeket nem lehet a későbbi felhasználókkal megtéríttetni, akkor a tudás potenciális előállítói nem lesznek érdekeltek a költségek vállalásában.

Ez az érdekellentét a legnagyobb akadály a tudás előállítása előtt. A kutatásfejlesztéssel járó költségeket csak abban az esetben lesznek hajlandóak vállalni a profitorientált vállalatok, hogyha lehetőségük nyílik az eredményből profitot húzni.

Részleges kizárhatóság megoldható jogi eszközökkel. A jog erre a feladatra találta ki a szellemi tulajdonjogi védelem rendszerét. A szellemi tulajdonjog-védelem két fô eleme a szerzői jogvédelem és az iparjogvédelem. Ez utóbbin belül beszélhetünk szabadalomról, formatervezésiminta-oltalomról, használatiminta-oltalomról, növényfajta-oltalomról, kiegészítő oltalomról, földrajzi árumegjelölésröl és védjegyoltalomról.

Disszertációmban a szabadalom, mint iparjogvédelmi forma közgazdasági hatásairól, illetve a hatásait befolyásoló külső tényezőkről kívánok írni. ${ }^{6}$ A szabadalom és a szerzői jog közötti legfontosabb különbség, hogy míg az előbbi esetében a védelem a benne foglalt találmány lényegére, tartalmára vonatkozik, addig az utóbbi esetben a védelem a konkrét megjelenési formát érinti.

Röviden áttekintve elöször a szabadalmak kialakulásának történetét és okatit, utána a disszertáció témájának lehatárolása érdekében bemutatom a szabadalmi védelemmel párhuzamosan, vagy annak helyettesítőjeként alkalmazott nem szellemi-tulajdonjogi védelmi módszereket.

\footnotetext{
${ }^{5}$ Míg az új tudás előállítása gyakorta hosszú időn át magas költségekkel jár, a már meglévő, működő, kipróbált technológia „lekoppintása”, adaptálása jóval alacsonyabb költséggel megvalósítható (Meyer 1995).

${ }^{6}$ A szabadalmak esetében disszertációmnak nem célja a jogi szabályozásnak a precíz ismertetése, vagy a szabadalmaztatás menetének bemutatása. A bemutatandó elemzéseket egy absztrakt, modell szintü szabadalmi intézményrendszer segítségével mutatom be.
} 


\section{A szabadalmak kialakulásának történetéről és okairól}

A szabadalmak intézményének illetve annak különböző gazdasági vonatkozásainak kutatása azzal párhuzamosan kap egyre nagyobb hangsúlyt, minél inkább növekszik a tudás-alapú gazdaság jelentősége a világgazdaságon belül. A szabadalmak kialakulása és fejlödése azonban természetesen következménye és nem pedig oka az említett változásoknak. A „patent” szó, a szabadalom angol megfelelője melléknévként „nyitott”-at jelent, főnévként pedig a latin „litterae patentes” fordítása, ami nyitott levelet jelent. A levél nyitottsága arra utalt, hogy ebben az uralkodó bizonyos előjogokat vagy címeket biztosított, és hirdetett ki, a mai konnotáció a szabadalmaztatott tudás nyilvánosságra hozatalával csak egy jóval későbbi állapotot tükröz (David 1992). A mai szabadalmakhoz hasonló előjogokat már az 1330-as évektől biztosítottak Angliában, azzal a céllal, hogy a kontinensről érkező különböző foglalkozású mesteremberek meghonosítsák a szigetországba még el nem jutott technológiákat. Előjogaik szerint 14 évig egyedül gyakorolhatták mesterségüket egy adott területen (amely idő a tanoncok két generációjának kinevelésére elegendő volt). Ugyanebben az időben a Velencei Köztársaságban olyan jogokat adtak ki a város kormányzói, amelyek a kívülröl származó mesterembereket ösztönözték arra, hogy országukban használt gépeket és módszereket honosítsanak meg Velencében. Vagyis a 14. században a szabadalom-jellegü jogok inkább a már meglévő tudás transzferálását segítették, nem pedig az új tudás előállítását.

A velencei szenátus az első szabadalmakat általánosan szabályozó törvényt 1474. március 19-én hozta meg. Ezen törvény szerint ha valaki egy korábban ismeretlen szerkezetet épít meg, vagy valamilyen más hasznos újítást talál fel, és ezt bejelenti a megfelelő hivatalnál, 10 évre szólóan jogot formálhat arra, hogy találmányát más az ő engedélye nélkül ne használhassa fel. „A szabadalom engedély az információ monopolizálására” (Nordhaus 1967, 1. o.) A szabadalmi oltalom - és általában a szellemi tulajdonjogok - szerepe az, hogy mesterségesen szükössé tegyenek egy olyan jószágot, amely esetében a szűkösség a jószág jellegéből fakadóan szükségszerüen hiányzik (May, 2005). Ez a mesterségesen megteremtett szükösség szolgál alapjául a szellemi termékek esetében a (legalább részleges) kizárhatóságnak és teszi lehetővé a belőlük származó hasznok (ismét csak legalább részleges) elsajátítását. A szellemi tulajdonjogi védelem különböző eszközeinek - mint például a szabadalmak, a védjegyek és a szerzői jogok másik célja tehát az, hogy racionálissá tegye az erőforrások beruházást a szellemi termékek 
termelésébe ${ }^{7}$, amely „előmozdítja a tudomány és a művészetek fejlődését” azáltal, hogy „meghatározott időre a szerzőknek és feltalálóknak kizárólagos jogot biztosít írásaik, illetve találmányaik felett” (David, 1992, az Egyesült Államok alkotmányát idézi).

Angliában például olyannyira bőkezüen és széleskörüen osztogatták ezeket a fentebbi értelemben vett monopóliumokat, hogy az 1600-as évekre gyakorlatilag a teljes gazdaság monopoljogokkal súlyosan terheltté vált. 1623-ban aztán a parlament által elfogadott Statute on Monopolies kimondta, hogy minden korábban adományozott uralkodói monopol-engedély (azaz szabadalom, patent) törvénytelen, kivéve azokat, amelyeket egy első és valódi feltalálónak biztosítottak (David 1992). A rendelet egységesen 14 évben határozta meg a védettség időtartamát.

A szabadalmaknak ebben a megfogalmazásában már egyszerüen, de benne van az a két alapelv, ami a modern kori szabadalmak két fö eleme: a találmány újszerüsége és az első benyújtó elve. Az előbbi azt jelenti, hogy csak olyan találmány szabadalmaztatható, ami abszolút újdonság, nem nyilvánvaló (vagyis kreatív emberi közremüködés kell a felfedezéséhez) és kereskedelmileg hasznosítható (kizárandó a tisztán tudományos eredményeket a szabadalmaztatható tudás köréből) (Foray 2004, 132. o.).

Bár a szabadalmi védelem számos vita forrása lett a későbbiekben, és még a nem vitás esetekben is jótékony hatásai mellett társadalmi jóléti veszteséget is okoz, mégis „olyan ösztönzést jelentett, amely nélkül a kapitalizmus kibontakozása szempontjából döntő XVIII. századi textilipari találmányok nem jöhettek volna létre” (Weber 1979, 250. o.). A szabadalmi védelmi szabályozás csökkentette a feltalálással és innovációval, valamint a szellemi alkotásokkal kapcsolatos tulajdonjogi kockázatot (Czeglédi 2009) és így a tranzakciós költségeket is. Ez nagyban elősegítette, hogy az újítások a modern gazdaság hajtóerőivé váljanak (Takalo 1999).

\section{Alternatív módok a kizárhatóság megvalósítására}

A kizárhatóság, különböző mértékben, egyéb módokon is megvalósítható. Egy, talán a szabadalmi védelemhez leginkább hasonlító mód az üzleti titok (trade secret). Az üzleti titokként kezelt tudást nem kell nyilvánosságra hozni, mint a szabadalom esetében, viszont ha végül ismertté válik, nem lehet megakadályozni a tudás felhasználását. Az üzleti titok kiszivárogtatásának jogi következményei vannak, kártérítés formájában, de a szankció nem

\footnotetext{
${ }^{7}$ A szükösség a tudás esetében valójában az első előállításnál áll fenn, míg a későbbi felhasználásnál nem (Szabó - Hámori 2006). Míg egy hagyományos termék esetében a sokadik darab értéke is ugyanakkora, mint az elsőé, a tudás esetében az újraelőállítás haszontalan.
} 
az üzleti titokkal védett tudást felhasználó versenytársat, hanem az üzleti titkot kiszolgáltatót sújtja.

Fontos megjegyezni ugyanakkor, hogy innovációk keletkeztek a szellemi tulajdonjog-védelmi rendszer (ami maga is egy innováció volt!) intézményesülése elött is. ${ }^{8}$ A tudás például néha magában hordozza a jutalmát. A feltaláló számára a jutalom nem csak anyagi lehet: az új tudás ellenértékének egy része lehet például az elismertség, a reputáció, a tudományos megbecsülés. Az „Open Source” és a „Copyleft” mozgalmak az ilyen fajta jutalmakra építve magyarázzák meg, hogy a kizárás megvalósítása nélkül is lehet innoválni. ${ }^{9}$

Nem jogi jellegü módszer a kizárásra az átfutási idő (lead time). Ebben az esetben a kizárás szintén csak időlegesen valósul meg, amennyiben nem lehet azonnal lemásolni az új tudást. Még ha az innovációt nem is védi semmilyen szellemi tulajdonjog-védelmi mechanizmus, időbe kerülhet, amíg az innovációt a versenytársak megfejtik. Termékek esetében ez történhet ún. reverse engineering által, amikor a versenytársak az innovatív terméket tanulmányozva jutnak el az innovatív technológiához. Az ehhez szükséges idő függhet attól, hogy a lemásolni kívánt technológiai tudás mekkora részben hallgatólagos. A nem kodifikált tudás, mint korábban bemutattam, szükségesség teszi a tudás eredeti birtokosának aktív közremüködését a tudástranszferálásban, annélkül pedig a folyamat időben elhúzódhat. Bizonyos innovációk esetében ez az idő éppen elég ahhoz, hogy a kutatás-fejlesztés költségei megtérüljenek. Cohen et al. (2000) egy felmérésben megvizsgálta, hogy az innovációk védelmére alkalmazható különböző módszereket az egyes iparágakban mennyire tartják effektívnek. A lead time számos iparágban bizonyult hatékonyabbnak vélt innováció-védelmi mechanizmusnak, mint a szabadalom. A disszertációban ezzel a fajta védelemmel mégsem foglalkozom, mivel ez nem jogi jellegü védelem, a „mekkora kell, hogy legyen az optimális méretű átfutási idő” kérdés így nem is értelmezhető. A lead time erősen iparág- és akár konkrétan találmányfüggő, valamint meglehetősen bizonytalan, hogy mekkora előnyt biztosít a feltalálónak a versenytársakkal szemben, mennyi ideig tevékenykedhet mintegy természetes monopóliumként.

\footnotetext{
${ }^{8}$ Sőt azóta is léteznek olyan iparágak, szabadalmi védelem nélkül is jelentős innovatív tevékenység zajlik. Boldrin és Levine (2005) tanulmányukban amellett érvelnek, hogy versenyzői piac esetében, szabadalmi védelmen alapuló monopoljogok híján is érdekeltek a szereplők az innovációban, sőt, ez a piacforma megfelelöbben ösztönzi a tudáselöállítást.

${ }^{9}$ Az Open Source közgazdaságtanáról lásd pl. Lerner - Tirole (2002).
} 


\subsection{Az innováció nem modell-szintü megközelítései}

Az innováció definícióiból kiderült, hogy az innovációnak fontos eleme az új tudás. A tudás tulajdonságait áttekintve azonban egy konfliktust fedeztünk fel, amely hátráltathatja az új tudás keresését: a rivalizálás hiánya miatt érdemes mindenki számára hozzáférhetővé tenni az új tudást, de ha a nem fizetők kizárását nem tudjuk megoldani, akkor a tudás potenciális előállítóinak nem áll majd érdekükben az új tudás megtermelése. Ennek a konfliktusnak egy lehetséges feloldását kínálja a szabadalmi védelem. Mielőtt a tudástermelés, innováció modelleket használó megközelítéseire térnék rá, szükségesnek érzem a nem modell-szintü megközelítéseket bemutatni. Ezek az elméletek az innovációs folyamatra, annak lépéseire, szereplöire koncentrálnak, melyeket a későbbi modellek fekete dobozai sokszor adottságnak kezelnek majd. Találkozunk azonban itt is olyan fogalmakkal, melyek a későbbiek szempontjából fontosak lesznek.

Először az innovációk két alapvetően különböző formáját, az inkrementális és radikális innovációt mutatom be. Ezek után e két féle innovációhoz kapcsolva az új tudás megszerzésének, a vállalati innovációnak egy módját, a tanulást és azzal összekapcsolva a know-how/know-what/know-why megkülönböztetést vezetem be. A különböző fajta tanulást a vállalatok különböző tudásbázison teszik meg: ezeket a tudásbázisokat azonosítom az analitikus/szintetikus/szimbolikus megkülönböztetéssel.

\section{Inkrementális és radikális innováció}

Kiindulási pontként fontos különbséget tennünk úgynevezett radikális és inkrementális, vagy más néven fokozatos, járulékos innovációk között (Asheim - Coenen 2006). Az inkrementális innováció úgy határozható meg, mint a növekedést szolgáló és azzal együtt járó fokozatos tanulási folyamat eredménye, amelynek során a szervezetek cselekvés és használat közben tesznek szert számukra új tudásra. Kétségtelen, hogy a felzárkózó innováció fontos, kisebb kutatás-fejlesztési potenciállal bíró vállalatok, régiók számára biztosíthatja, hogy versenyben maradhassanak. Az innováció ekkor nem annyira a kreativitástól, hanem az abszorptív, tudás-befogadó kapacitástól függ (Zahra - George 2002). A vállalatok, illetve régiók számára a hosszú távú növekedést azonban a radikális innovációk, a valódi újítások hozzák meg (Asheim - Coenen 2006, 117. o.). Az Oslo Kézikönyv radikális innovációnak nevez egy innovációt, ha annak ,jelentős hatása van a piacra, és a piacon jelen lévő vállalatok viselkedésére” (OECD 2005, 58. o.). 


\section{Know-how, Know-what, Know-why}

Az új tudás megszerzésének egyik lényeges módja a tanulás. A vállalatok közti versenyben felértékelödik a tudás szerepe, és amelyik vállalat hatékonyabban tud tanulni, az versenyelőnyre tehet szert a többiekkel szemben. „A tudásalapú gazdaság központi folyamata lényegében az innovációk sorozatából álló technológiai változás” (Bajmócy 2008, 28. o,). Amennyiben az újítást, innoválást úgy fogjuk fel, mint a tanult és megszokott dolgokon való túllépést, akkor akár azt is mondhatjuk, hogy a tanulás és az innováció éppen egymás ellentétei, de a tanulás és innováció kapcsolata ennél sokrétübb (Hámori 2012). Például az iménti szakaszban említett inkrementális/radikális megkülönböztetés segítségével a két fogalom könnyedén összekapcsolható.

Az úgynevezett learning-by-doing és learning-by-using nagyon fontos része az új technológiai tudás előállásának, de ez az új tudás nem valami gyökeresen új dolog megalkotását jelenti, hanem vagy már objektíve létező dolog új bevezetését egy szervezetnél, vagy valami szintén már objektíve meglévő termék, folyamat adaptálását. A learning-by-doing az első lépése volt a tudás és a technikai fejlődés endogenizálásának a közgazdasági modellekben (Arrow 1962a). Ehhez a fajta tanuláshoz a tudás egyik leggyakoribb használata, a know-how tartozik. Ez a fajta, a használattal és gyakorlás által megszerzett tudás aztán különbözö formákban tárolódik el, akár emberi tőkében, akár szervezeti rutinokban. A Nonaka-féle tudásspirál, más néven a szervezeti tanulás SECI modellje (Lengyel 2012) részletesen leírja, hogy hogyan zajlik a szervezetben ennek a többnyire implicit tudásnak a továbbadása. A learning-by-using tanulási módhoz a tudás egy másik fajtája, a know-what tartozik. Ez a fajta tudás vevők és eladók közötti interakciókból származik és a vállalatok sokoldalú és komplex kapcsolatrendszerében generálódó információk alapján adaptációkat hoz létre (Garud 1997).

A radikális innovációk megalkotásának módja pedig a tanulmányozás általi tanulás, vagy a learning-by-studying (Garud 1997). A tanulmányozás általi tanulás szisztematikus keresést, kontrollált kísérletezést és szimulálást tartalmaz, aminek eredményeként valamilyen termék, termelési eljárás müködésének elvére, mikéntjére vonatkozó tudás, know-why, áll elő. ${ }^{10}$ Nordhaus gyakran idézett cikkében egy általános kifejezést használ az innovációra, mint „mindazon tevékenységekre, amelyek kiterjesztik a techikai tudás szintjét” (Nordhaus 1969, 18. o.). Disszertációmban az innovációkra, mint új technológiai tudás előállítására, a nordhausi értelemben kívánok koncentrálni. ${ }^{11}$

\footnotetext{
${ }^{10}$ Nem minden originálisan új tudás áll elő szándékolt és célzott tanulmányozás általi tanulás kapcsán, hanem a felfedezés lehet akár egy más célú kutatás „mellékterméke”, véletlen eredménye is.

${ }^{11}$ Az idézett helyen Nordhaus ugyan az „invention” kifejezést használja, de a későbbiek alapjául szolgáló írásában már innovációról beszél.
} 


\section{Analitikus, szintetikus és szimbolikus tudás}

A radikális innovációkkal és a szabadalmaztatással kapcsolatban érdemes a tudásnak egy további csoportosítását bevezetni. Nem mindenfajta iparágban bír ugyanis azonos jelentőséggel az új technológiai tudás szabadalom általi védelme, ezért ez a témám szempontjából egy további szükítést jelent.

A tudásnak három fajtáját különbözteti meg Asheim et al. (2005), és az iparágakat az alapján sorolja be, hogy tudásbázisuk melyik fajta tudáshoz áll legközelebb a három fó típus közül. Az elsőféle tudás az analitikus tudás. Ez a fajta tudás leggyakrabban tudományos tudás, ahol az új tudás többnyire szisztematikus, kutatómunkával áll elö, kognitív és racionális folyamatokon a deduktív tudományos módszertanon keresztül. Az analitikus tudás előállításához magason képzett kutatók kellenek, amennyiben vállalatoknál folyik a kutatás, akkor saját $\mathrm{K}+\mathrm{F}$ részleg végzi az analitikus tudás előállítását, de a speciálisabb kutatásokban nagy jelentősége van az egyetem-ipari kapcsolatoknak is. Az analitikus tudás esetében a végeredmény nagyrészt explicit, leírható tudás, nem ritkán publikációk, szabadalmak formáját ölti. A tudás alkalmazása radikális újdonságokban nyilvánul meg, új termékekben vagy termelési eljárásokban.

A másodikféle tudás a szintetikus tudás. A szintetikus tudás lényege a már meglévő tudásdarabok új módon való összekombinálása, egy gyakorlati probléma hatékony megoldására. Az innováció előállítási folyamata itt inkább induktív, kísérletezésen, modellezésen vagy szimulációkon keresztül történik. Az előálló tudás jelentősebb része hallgatólagos tudás, kötött az adott céghez vagy problémához. Mivel maga a problémafelvetés is kontextusfüggő, ezért ennek a fajta tudásnak az előállításánál nagyobb szerepet kap a beszállítókkal vagy a vevőkkel való kooperáció, a tanulva, használva illetve interakciókon keresztüli tanulás. Ez a fajta tudás kevésbé radikális, inkább inkrementális innovációkban ölt testet, módosítva, javítva a korábbi tudást, termékeket, eljárásokat.

A harmadik tudásféle a szimbolikus tudás. Ebben az esetben a hangsúly az új ötletek, megjelenés, forma, design előállításán van, semmint új termékekén vagy eljárásokén. Az új tudás előállításánál az információknál nagyobb szerepet kapnak a jelzések, a képzettségnél nagyobb szerepe van a képzelőerőnek. Az eredményként megszülető tudás erőteljes hallgatólagos komponenssel bír.

Különböző iparágak esetében az egyes tudásfajták más és más jelentőséggel bírnak (1.1. ábra). A gépjárműiparban például a szintetikus és az analitikus tudásnak van nagy jelentősége, a szimbolikus tudásnak jóval kevésbé, míg a reklámipar főleg a szimbolikus tudásra épít. 
1.1. ábra: Analitikus - szintetikus - szimbolikus tudás

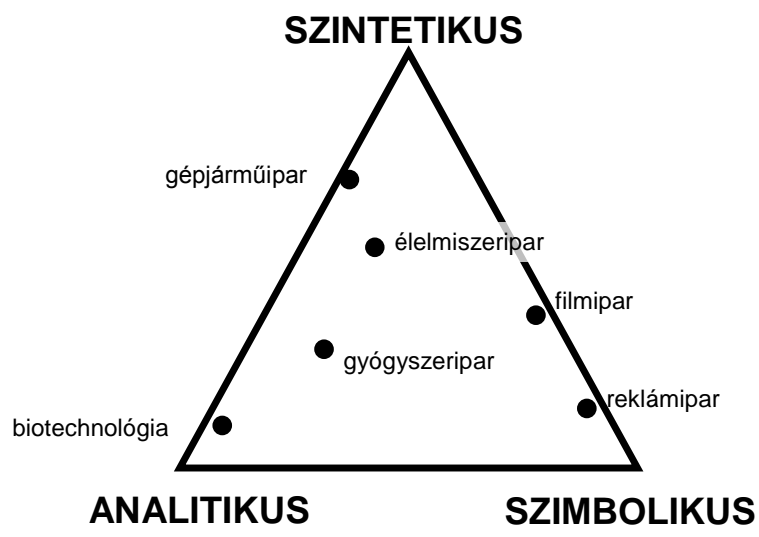

Forrás: Asheim et al $(2005,10$. o. $)$

Disszertációm szempontjából azért fontos ez a fajta megkülönböztetés, mert a tudás szellemi tulajdonjogokkal, szabadalmakkal történő védelme sem egyforma jelentőségü az össze iparágban. Cohen et al. (2000) kérdőíves felmérésben vizsgálta meg, hogy mely iparágak esetében mely szellemi tulajdonjog-védelmi mechanizmusok bírnak legnagyobb jelentőséggel. Termék innováció esetében magas jelentőséget jelentettek a megkérdezésben az orvosi berendezések, a gyógyszerek, a gépjármü-alkatrészek és a számítógépek gyártói. Folyamat innovációnál az üzemanyaggyártás, a gyógyszerek és az orvosi berendezések álnak a vezető helyen. Úgy látszik tehát, hogy a szabadalmak föleg az analitikus és szintetikus tudás védelmében játszanak fontos szerepet.

\subsection{Az innováció modellezési lehetőségei}

A növekedéselméletek egy fontos tanulsága, hogy hosszú távú növekedés csakis a technikai haladáson keresztül lehetséges. A technikai haladás pedig innovációkon keresztül valósulhat meg. A különböző közgazdaságtani irányzatok jelentős különbségeket mutatnak azonban atéren, hogy honnan származnak ezek az innovációk, milyen törvényszerüségek mozgatják őket. A növekedési modellek időbeli változását részletesen bemutatja Aghion Howitt (1998), disszertációm szempontjából egy rövid összefoglalás elegendő.

A hagyományos kiindulópont az 1950-es évek végén kidolgozott Solow-Swan féle neoklasszikus növekedési modell. Ebben a modellben a növekedést a tőkeállománynak a megtakarításokból finanszírozott beruházások általi bővülése eredményezi. A növekedés azonban csak egy bizonyos szintig tart, mivel változatlan munkáslétszám mellett a tőke csökkenő hozadékot mutat. A tőkeállomány növekedése növeli ugyan a kibocsátást, ezáltal 
a megtakarításokat és a beruházásokat is, azonban csak csökkenő ütemben, ugyanakkor a tőkeállomány növekedésével állandó ütemben nő a tőke elhasználódása is. A tőkeállomány csak addig nőhet, amíg az amortizáció meg nem egyezik a beruházások nagyságával: ekkor a tőkeállomány bővülése és a gazdasági növekedés megáll. A munkások számának növekedése a tőke csökkenő hozadékán nem változtat, így a növekedésnek ismét lesz egy felső korlátja. A tőkeállomány bővülése továbbra is csökkenő mértékben növeli a kibocsátást és a beruházásokat, a tőkeállomány viszont most már nem csak az amortizáció állandó ütemével csökken, hanem a növekvő munkáslétszám miatti hígulás ütemében is.

Mindezek a növekedésre nézve elkeserítő eredmények azonban csak egy adott, változatlan technikai színvonal mellett érvényesek. Változatlan technikai színvonal (a modellben a teljes tényezőtermelékenység, TFP által leírt nagysága) mellett a skálahozadék állandó, a munka és a tőke parciális hozadékai pedig csökkenőek. A technikai haladás, új technológiai tudás előállítása azonban megváltoztatja a termelési függvényt. A munkások számának minden határon túli növekedése nem lehetséges, a tudás azonban, mint láttuk, kimeríthetetlen erőforrás, így a növekvő tudásállomány növekvő hozadékot eredményez, és ezáltal folyamatos gazdasági növekedést tesz lehetővé. A neoklasszikus növekedési modell azonban külső adottságként kezelte a technikai haladást, hatásait meg tudta mutatni, arra azonban nem tudott magyarázatot adni, hogy milyen módon jön létre. A technikai szint növekedése azonban ugyanúgy gazdasági döntések eredménye, mint a tőkeállomány bővülés, ezért érdemesnek látszott bevinni a modellen belülre, vagyis endogenizálni.

Egy korai kísérlet a technikai haladás eredetének magyarázatára Arrow (1962) magyarázata, amelyben a technikai fejlődést egy tanulási folyamat elöre nem látott következményeként, a learning-by-doing jelenségével magyarázta. Erre a fajta felfogásra már az inkrementális innovációknál utaltam. Arrownál ez a fajta technikai haladás a tőkeállomány nagyságától függ. Más modellekben a technikai haladás hol a humán tőke, hol pedig az ipari kutatásokból származó spillover-hatásoktól függően következik be (Ács - Varga 2000). Mindezeknek a modelleknek közös tulajdonsága, hogy az új tudást mindenki számára hozzáférhetőként, közjószágként kezelik, méghozzá a már korábban említett két fontos tulajdonsága, a rivalizálás és a kizárhatóság hiánya miatt. Az endogén növekedéselméletek, mint például az AK modellek (Aghion - Howitt 1998) a technikai fejlődés ütemét a modellen belül meghatározódóvá teszik, racionális gazdasági szereplők döntéseinek eredményeként magyarázzák, és kiküszöbölik a tőke csökkenő hozadékából eredő növekedési korlátot. 
Az endogén növekedési elméleteknek négy csoportját említi Menell és Scotchmer (2007), ezek az evolúciós modell, az indukált technikai változás modellje, az ötletalkotás exogén folyamata modell és a tudástermelési függvény modell.

Az evolúciós modell szerint, melynek megszületését Nelson és Winter 1982-ben megjelent „A gazdasági változás evolúciós elmélete” címü könyvéhez kötik, a technológiai fejlödés egy evolúciós folyamat szerint zajlik, melyet bizonytalanság, útfüggőség, nem egyensúlyi helyzetek és állandó változás jellemez.

Az indukált technikai változás modelljében a technológia változását, illetve az új technológiák iránti kutatást a tényezőárakban bekövetkező változások idézik elő. A kutatás-fejlesztés olyan területek felé irányul, ahol a fontos erőforrás megdrágul.

Az ötletalkotás exogén folyamata modell a kutatási ötletekre, mint szükös erőforrásra koncentrál, és a modell szerint a sikeres innovációhoz egyrészt motiváció (például a prospektív profit általi), másrészt pedig szükösen rendelkezésre álló innovatív ötlet szükséges.

A tudástermelési függvény modellek függvényszerü kapcsolatot tételeznek fel a kutatás-fejlesztési projektek inputjai (pénz, kutatók száma, munkaórák stb.) és outputjai között (az innováció minősége, fontossága vagy a valószínűség egy innováció megalkotására). A legutóbbi két elméletben a kutatás-fejlesztési befektetések végső mozgatója a profitlehetőség, amely profitlehetőség a szereplők számára ismert, és az innovációból eredő tökéletlen versenyből ered.

A disszertációmban vizsgált és kibővített modellek a tudástermelési függvény modellek családjába tartoznak. A tudástermelési függvények megadhatóak egészen bonyolult, sokváltozós formában is, mint például Varga (2009) esetében, de az általam vizsgált egyszerü modellekben a tudástermelési függvény esetében a tudástermelés inputja kizárólag a kutatás-fejlesztésre fordított kiadás, az outputja pedig egy termelési költségmegtakarítás formájában megnyilvánuló folyamat-innováció. Az általam alkalmazott modell az innovációs folyamatra magára nem fordít figyelmet, hanem azt egy fekete dobozként kezeli, melybe beledobva a kutatás-fejletsztési forrásokat, determinisztikusan előáll egy költségelőnyt jelentő innováció. Magának az innovációs folyamatnak a megértése nem tárgya ennek a fajta modellnek. Az innovációs modellek különböző generációit mutatja be Bajmócy (2008), melyek az általam vizsgált modellben nyitvahagyott némely kérdésekre keresik a választ az innovációs folyamat részletesebb vizsgálatával. 
Fontos megkülönböztetnünk, hogy milyen keretek között megy végbe a kutatásfejlesztési tevékenység a gazdaságban.

Radikális innovációk szervezett keretek közti elöállításának történetében Antonelli (1999) négy nagyobb szakaszt különböztet meg az ipari forradalom óta: vállalkozók általi innovációk, intézményi változatosság, vertikális integrációk és technológiai kooperációk szakasza.

Az első szakasz a kreatív vállalkozók és vállalkozások általi innovációk. Az újdonságok bevezetésének alapvető módja a schumpeteri hagyományok alapján az új vállalkozások indítása. Az innovatív vállalkozó innovatív termékével vagy termelési eljárásával új vállalkozásként megjelenik a piacon, a piac pedig a maga természete szerint szelektál, és a nem életképes, kevésbé hasznos, vagy éppen meghaladott innovációkat kiszelektálja, és csak a legjobb, legnagyobb hasznosságot eredményezö, legkorszerübb innovációk maradnak versenyben.

A második szakasz az intézményi változatosság szakasza. Erre a szakaszra az egyetemek és az ipar közötti együttmüködés és munkamegosztás a jellemző. Főként az egyetemek azok a helyek, ahol magasan kvalifikált kutatók az újdonságokat létrehozzák, kutatómunkájukat közösségi forrásokból finanszírozzák. E mögött az elképzelés húzódik meg, hogy a tudás közjószág. Ha azonban így van, akkor mivel pozitív extern hatásokat generál, mindenki számára elérhetőnek kell lennie, amely esetben a magánfinanszírozása kevésbé kivitelezhető. Az előállt új tudás túlcsorduló hatásokat generál az ipar számára, aki az újítások ipari alkalmazásait fejleszti ki.

A harmadik szakaszt vertikális integrációnak nevezi. Ebben a szakaszban a kellően nagy vállalatok saját $\mathrm{K}+\mathrm{F}$ részleget hoznak létre, és a kutatást kapun belülre hozzák. A saját maguk számára végzett kutatás-fejlesztést hatékonysági megfontolások vezetik, és nagy jelentőségű a már meglévő technológia, a belsőleg felhalmozódó tacit tudás és a kifejlesztett új technológiák közti folyamatos kölcsönhatás.

A negyedik szakasz elnevezése technológiai kooperáció. Ebben a szakaszban különböző vállalatok közötti kooperációk jelentik az új tudás előállításának domináns terét. $\mathrm{Az}$ egyes vállalatok szerteágazó specializált tudásának kombinációja szükséges az innovációk előállításához. A vállalati együttmüködések mind változatosság- mind pedig méretgazdaságosságot eredményeznek. A vállalatok egyszerre több kutatási projektben is részt vehetnek, ugyanakkor a költséges kutatási infrastruktúrát pedig közösen használhatják. A vállalatközi együttmüködések jelentős előnye, hogy az innovációhoz 
kapcsolódó tacit tudás a projekt végeztével több vállalatnál oszlik el és használható fel a későbbiekben.

A kutatás-fejlesztés jelenlegi leggyakoribb formája a vállalatok széles hálózata által müködtetett technológiai kooperáció (Lengyel 2012). A tudástermelésnek ez a fajtája a tudás kvázi-közjószág tulajdonságaira épít, és mint láttuk, iparáganként különböző jelentőséggel használja fel a tudásból származó piaci hatalom megvédésére a szabadalmi védelem intézményét.

Disszertációm első fejezetének célja az volt, hogy kutatási területet, az innováció és a szabadalmi védelem összefüggését egyrészt tágabb kontextusában mutassa be, másrészt körbe is határolja. A tudást számtalan módon lehetséges értelmezni, és még a közgazdaságtani vizsgálatokba is sokféle módon építhető be. Dolgozatomban én azonban ezek közül a technológiai tudással fogok foglalkozni, elválasztva azt például a tudományos tudástól, vagy a fogyasztók fizetési hajlandóságának ismeretétől, tudásától. A technológiai tudás előállítása és vállalati bevezetése innovációt eredményez. Az innováció komplex folyamata szintén nagyon sok oldalról megközelíthető, más aspektusaira koncentrál például az evolúciós elmélet, és másra az innovációs rendszerek elmélete. Disszertációm szempontjából a cél az innováció és a szabadalmi védelem intézménye közti kapcsolat megértése, így azt az irányzatot választottam ki, amely ezt a befolyásoló tényezőt helyezi előtérbe.

A következő fejezetben bemutatott modellek a vállalatok innovációira, a technológiai tudás termelésére, mint vállalati optimalizációs döntésre koncentrálnak. A vizsgálat középpontjában az áll, hogy a szabadalmi védelem intézménye hogyan befolyásolja a profitmaximalizáló vállalatok kutatás-fejlesztési döntéseit. A modellek ezen kívül állításokat fogalmaznak meg a szabadalmi védelem hatásáról az innovációkra, a vállalati profitra és a társadalmi jólétre is. Elöször ezeket a modelleket tekintem át, majd az optimális szabadalmak elméletének egy továbbfejlesztését mutatom be. 


\section{Az optimális szabadalmak elmélete}

Az innováció és a tudástermelés rendkívül kiterjedt irodalmának egy szelete tehát az, amely tudástermelési függvények formájában igyekszik megragadni a tudás előállítását. A tudástermelési függvények esetében általánosan arról van szó, hogy az előálló tudás, technikai fejlödés nem exogén a modell szempontjából, hanem valamilyen változó hatására határozódik meg. Az előállt tudást valamilyen outputmutatóval mérik (például éppen a szabadalmak számával), míg az inputoldali ráfordítások között olyan tényezők szerepelnek, mint a magán vagy az állami $\mathrm{K}+\mathrm{F}$ kiadások vagy a kutatás-fejlesztésben alkalmazottak száma.

Az általam felhasznált modellek esetében, még specializáltabban, a tudástermelési függvény úgy jelenik meg, hogy egy adott nagyságú kutatás-fejlesztési befektetés előállít valamilyen nagyságú, értékü tudást, ami a modellben költségelöny formájában jelenik meg. Ezt a termelésben felhasználva makroszinten gazdasági növekedés, mikroszinten pedig vállalati piaci előny lesz az eredménye. Ez a tudáselőállítás lehet akár determinisztikus, vagyis olyan, hogy a nagyobb befektetés biztosan elöállít valamilyen nagyobb eredményt, vagy pedig sztohasztikus, vagyis olyan, hogy a növekvő befektetéssel egyre nagyobb és nagyobb valószínűségü sikert „,vásárolunk”.

A vállalatok azonban csak akkor lesznek hajlandóak pénzt áldozni a kutatásfejlesztésre, ha annak eredményeiből profitálnak. Ennek egyik, ha nem is egyetlen módszere, hogyha szabadalmi védelem formájában elsajátíthatóvá tesszük a vállalatok számára az innovációjukból származó hasznokat, vagy legalábbis azoknak egy részét. A szakirodalomnak azzal a szeletével foglalkozom most, amely a szabadalmi védelem intézményének, mint ösztönzőnek hatását explicit módon vizsgálja az innovációra: a szakirodalom ezen ága optimális szabadalom elmélet (theory of optimal patents), vagy szabadalom desing (patent-design) elmélet néven ismert.

A jelen fejezet kiindulópontjaként az első alfejezetben bemutatom azt a modellt, amely a szabadalom intézményének a tudástermelésre gyakorolt hatását vizsgáló mikromodellek közül az első és legegyszerübb, William Dawbney Nordhaus 1967-es írása alapján. A későbbiekben ez a modell szolgál alapul, hogy megvizsgálhassuk a szabadalom intézményének lehetséges változatait és a különböző irányú kiterjesztések hatásait. 
A második alfejezet a Nordhaus-modellből kiindulva bemutatja, hogy a szabadalmi rendszernek milyen további, az eredeti modellben nem vizsgált paraméterei lehetnek, melyek az innovációra - új technikai tudás előállítására - és ezen keresztuil a társadalmi jólét szintjére befolyással bírnak. Ezek a tényezők mind potenciális eszközök lehetnek a gazdaságirányítás kezében, mikor az optimális szabadalmi rendszer megalkotására törekszik. A fejezet igyekszik egyfajta áttekinthető rendszerezését nyújtani a modellváltozatoknak.

Az utolsó alfejezet pedig konklúzióként kitekintést nyújt a tekintetben, hogy a modellek milyen irányú további finomításai jelentek még meg a szakirodalomban.

A szabadalmi védelem esetében valójában egy mesterséges tulajdonjogról van szó. Ha valaik előállít egy olyan új tudáselemet, amit a termelésben fel tud használni, akkor az újítás nyilvánosságra hozatala ellenében jogot kap arra, hogy másokat kizárjon az innováció felhasználásából. Az új technológiai tudást más a feltaláló engedélye nélkül nem használhatja fel, és ilyen módon ő egyedül sajátíthatja el annak hasznait. Nordhaus ezt így fogalmazza meg: „A szabadalom engedély az információ monopolizálására” (1967, 1. o.). A szabadalom által megtestesített tulajdonjogokat azonban érdemes korlátozni időben, tárgyukban valamint térben egyaránt. A szabadalmak esetében az exkluzivitás nem olyan tökéletes módon valósul meg, mint a fizikai tulajdon esetében. A szellemi tulajdonjog korlátozott időben, amennyiben a kizárólagos felhasználás joga csak meghatározott ideig jár (Európában és az Egyesült Államokban ez az idő egységesen 20 év a gyakorlatban). Korlátozott ugyanakkor tárgyában is, amennyiben egyrészt a szabadalmaztatható dolgok köre korlátozott (nem szabadalmaztatható például valamilyen felfedezett természeti törvényszerüség ${ }^{12}$ ), másrészt változó, hogy egy újítást mennyire konkrétan vagy absztraktan értelmezve lehet szabadalmaztatni. Korlátozott a tulajdonjog térben is (amennyiben a védelem csak az adott országban érvényes). A szellemi tulajdonjog védelme tehát nem korlátlan, nem feltétlenül tökéletes, így különböző módokon (lásd lentebb) a tudás mégis kiszivároghat további felhasználókhoz. Még ha a védelem tökéletes is, akkor sem biztos, hogy a végső kimenetel a feltaláló monopóliuma lesz, hanem megvásárolható az engedélye a tudás felhasználására.

A következőkben áttekintem, hogy az optimális szabadalmak elmélete hogyan teremt kapcsolatot a szabadalmi védelem időtartama és a vállalati innováció, vagyis a disszertáció

\footnotetext{
${ }^{12}$ A szabadalmaztathatóság szempontjából fontos különbségtétel tehát a felfedezés (discovery) és a feltalálás (invention). Dolgozatomnak nem célja a szabadalmi jog részletesebb ismertetése, így a szabadalmaztathatóság kritériumairól részletesebben lásd Risch (2008) vagy Putnam (2008).
} 
értelmezésében új technológiai tudás előállítása között. A bemutatott modellek normatív jellegűek, amennyiben azt keresik: milyen élettartamat kell meghatározni a szabadalmaknak ahhoz, hogy a vállalati innovációnak a társadalom szempontjából optimális nagysága áljon elő?

\subsection{A szabadalmak Nordhaus-modellje}

Nordhaus korai írásai közül sok foglalkozott a növekedés és a technológiai fejlödés témaköreivel. Leggyakrabban idézett müve e témában az 1969-es Invention, Growth and Welfare. Ennek egy időbeli előzménye az 1967-es cikke, melyben az innovációt és a jólétet elegánsan összekapcsolva rendkívül leegyszerüsítve mutatja be a szabadalmak jóléti hatásait. Mivel írásában a szabadalmi védelem intézményének a társadalmi szempontból optimális megkonstruálása volt a témája, az ezzel elindított irányzat a szakirodalomban az optimális szabadalmak elmélete néven vált ismertté. A szabadalmi védelem az innovátor és a társadalom közötti érdekellentétet igyekszik megoldani, a társadalom szempontjából optimális ösztönzést nyújtva a vállalatnak az innováláshoz.

Az alfejezet legelső részében bemutatom Nordhaus modelljének feltevéseit, és hogy hogyan értelmezi ő a modellben az innovációt. A második részben ezután rámutatok, hogyan jelenik meg a modellben az innováció kvázi-közjószág tulajdonságaiból adódó érdekellentét az innovátor és a társadalom között. A harmadik részben megmutatom, hogy az alapmodell milyen megoldást talál erre az érdekellentétre a szabadalmi idő segítségével, és hogy milyen tényezők befolyásolják ennek a szabályozóeszköznek a használatát.

\section{Nordhaus modelljének feltevései és az innováció értelmezése}

Nordhaus modellje az első fejezetben említett Solow-Swan, illetve endogén növekedéselméletekkel szemben egyértelmüen neoklasszikus alapokon nyugvó mikro szemléletben igyekszik vizsgálni a technikai fejlődés, az innováció, és végső soron a tudástermelés ${ }^{13}$ jóléti hatásait a szabadalom intézményén keresztuil. A kiindulópontja egy tökéletesen versenyző iparág konstans termelési határköltséggel és lineáris keresleti függvénnyel. Egy vállalatnak lehetősége van innovációra. Az innováció úgy jelenik meg a modellben, hogy valamekkora $(R)$ erőforrás-felhasználással egy $B(R)$ nagyságú termelési költség-csökkenés érhető el. Ezt a modell „feltalálási lehetőség függvénynek” nevezi, az általam használt értelemben valójában egy tudástermelési függvényről van szó. A modellben a feltalálás folyamata nem igényel időt, csak erőforrás-ráfordítást. A vállalat által elhatározott optimális nagyságú invencióra fordított erőforrás azonnal és determinisztikusan előállítja a megfelelő költségcsökkentő innovációt, de a

\footnotetext{
${ }^{13}$ A tudástermelést és az innovációt a későbbiekben szinonimaként fogom használni. Emlékezzünk az első fejezteben alkalmazott egyik definícióra: „A technológiai innováció lényegében új tudás létrehozása, vagy már létező tudáselemek kombinálása új módokon, és ezek transzformációja gazdaságilag szignifikáns termékekbe vagy gyártási folyamatokba" (Ács-Varga 2000, 33. o.).
} 
költségcsökkenés mértéke az erőforrás-ráfordítás csökkenő ütemben növekvő függvénye. A csökkenő hozadék elve tehát a tudástermelésben is érvényesül. $B(R)$-et nevezhetjük az innováció fontosságának: nagyobb befektetéssel egy nagyobb költségmegtakarítást eredményező, fontosabb innováció, egy nagyobb technikai lépés tehető meg a modell szerint.

Nordhaus beszél termék- és folyamat-innovációról, illetve megkülönböztet drasztikus és átlagos, közönséges (run-of-the-mill) innovációkat. Az itt bemutatásra kerülő modell egy átlagos folyamat-innováció modellje. A modellben használt közönséges/drasztikus innováció megkülönböztetés nem feleltethető meg egyértelmüen az 1.4. fejezetben említett inkrementális/radikális megkülönböztetésnek. Ha az inkrementális innovációt cselekvés és használat közbeni tanulás révén elért költségcsökkentés, akkor Nordhaus mindkét típusú innovációja inkább radikális, tudatos kutatás révén elért újítás. Közönséges és drasztikus innováció között a különbséget csak a költségcsökkentés mértéke adja meg. Az alapmodellben egy már meglévő termelési folyamaton történik változtatás, fejlesztés, költségcsökkentés formájában, de ez a költségcsökkenés nem elegendően nagy ahhoz, a tudást monopolizálva a termelő növelje a piacra kerülő mennyiséget. Fontos feltételezés, hogy az innováció, ha egyszer előállt, onnantól kezdve a végtelenségig használatos az iparban, vagyis nem avul el, és nem befolyásolja a jövőbeli innovációk keresletét vagy kínálatát.

A 2.1. ábra mutatja be a innovátor vállalat termékének piaci keresletét, a termék kezdeti előállítási határköltségét $\left(c_{0}\right)$, az innováció utáni csökkentett előállítási költséget $\left(c_{1}=c_{0}-B(R)\right)$, és a termelt mennyiséget.

2.1. ábra. A szabadalmak Nordhaus-féle mikroökonómiai modellje

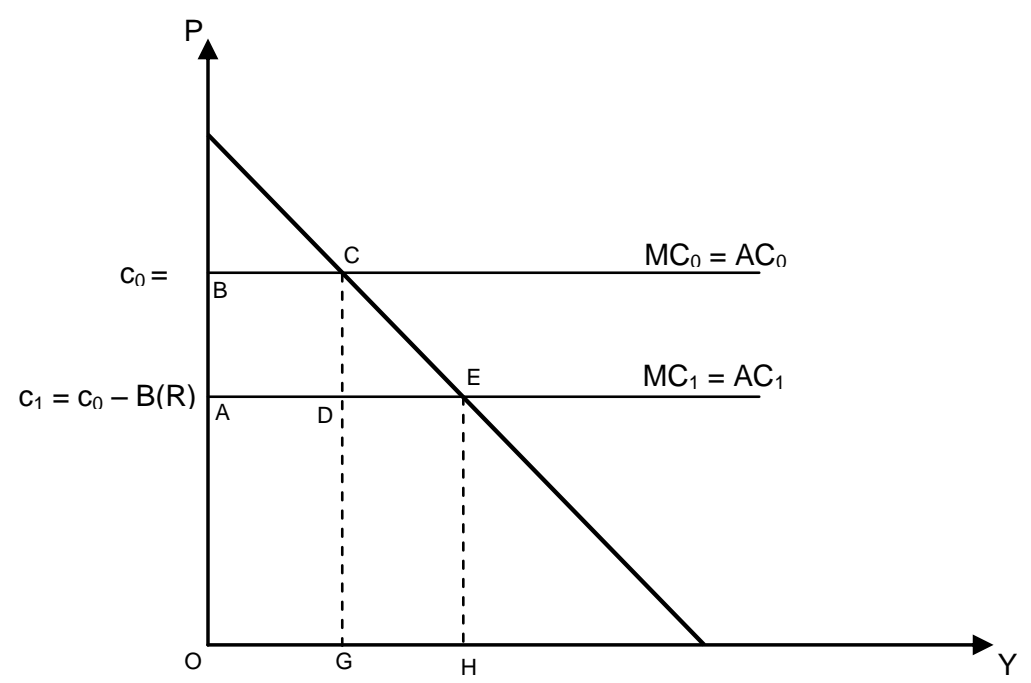

Forrás: Nordhaus $(1967,4$. o.) 
Ha mindenki az eredeti termelési határköltség mellett termel, a megtermelt kompetitív kibocsátást a vízszintes tengelyen $\mathrm{G}$ jelöli. Ha mindenki számára az alacsonyabb termelési határköltség az érvényes, akkor a kompetitív piac a H pontbeli mennyiséget állítja elő.

\section{Érdekellentét az innovátor és a társadalom között: a szabadalom élettartama}

A tudás, ha egyszer előállt, mindenki számára költségmentesen hozzáférhető szellemi tulajdonjogi védelem hiányában. Amennyiben a tudás elöállta után mindenki szabadon felhasználhatja, akkor a termék piaca egy alacsonyabb költségszint és nagyobb termelt mennyiség mellett újra egyensúlyba kerül, és a vállalatok profitja beáll a hosszú távon egyensúlyi nulla szintre. Ez a nulla profit nyilvánvalóan nem elegendő ösztönzés az innovátor számára a tudás előállításával kapcsolatos költségek viselésére, ezért lehetőséget nyújt neki az állam arra, hogy elöre meghatározott $t$ ideig az engedélye nélkül ne használhassa senki az általa előállított tudást. Ez a monopolhatalom a társadalom számára egy azonnali, de ideiglenes jóléti veszteséget eredményez: egy a tökéletes verseny feltételei mellett potenciálisan megszerezhető társadalmi többletről $t$ ideig le kell mondanunk. Ugyanakkor az innovátor számára biztosított exkluzív jogok teszik egyáltalán lehetővé azt, hogy a társadalom végül (a $t$ idő lejárta után) hozzájuthasson ahhoz a fent említett társadalmi többlethez, ami ezen exkluzív jogok hiányában az innováció elmaradása miatt elő sem állt volna: ez a szabadalomnak köszönhető később, hosszú távon előálló jóléti nyereség. A szabadalmi rendszer megalkotójának, a gazdaságirányító hatóságnak a feladata az, hogy megfelelő módon állítsa be a szabadalomnak ezt a döntő fontosságú $t$ paraméterét, vagyis a szabadalmi időt úgy, hogy kiegyensúlyozza a fenti értelemben vett ideiglenes jóléti veszteségeket és a hosszú távon megjelenő jóléti nyereségeket az innovátor profitmaximalizáló viselkedését is figyelembe véve. Az optimális szabadalmak elméletében a szabadalmi védelmi idő, a szabadalom hossza kulcsfontosságú tényező.

A szellemi tulajdonjogi védelem lehetővé teszi az innovátor számára, hogy a találmányából eredő hasznokat el tudja sajátítani. Versenytársai számára $c_{0}-c_{1}$ összegü royalty ellenében hozzáférhetővé teszi az általa előállított tudást addig, amíg a szabadalmi védelem le nem jár. Onnantól kezdve minden vállalat termelési határköltsége lecsökken. Ha az innovátor el tudja sajátítani royalty formájában a találmányának a hasznait, akkor a (tökéletes) szabadalmi védelem időtartama alatt profitként az ADCB négyszöget nyeri meg, $R$ összegü befektetés árán: minél hosszabb a szabadalmi védelem időtartama ceteris 
paribus, az annál jobban ösztönöz innovációra. ${ }^{14}$ Ugyanakkor adott $t$ szabadalmi védelmi hossz mellett annál inkább érdekelt az innovátor a kutatás-fejlesztésben, minél nagyobb költségcsökkenés érhető el $R$ befektetés árán, illetve a pótlólagos erőforrás-ráfordítás minél inkább növekvő mértékü költségcsökkenést jelent. ${ }^{15}$ Másrészről pedig az innovátor monopol-hatalmából eredő piaci torzítás a DEC holtteher-veszteséget jelképező háromszög: minél nagyobb a $t$ ceteris paribus, annál tovább kell várnia erre a jóléti többletnövekményre a társadalomnak. Ennek az elhalasztott jóléti többletnek a nagyságát pedig (konstans $t$ mellett) szemmel láthatólag a keresleti függvény meredeksége határozza meg.

\section{Az optimális szabadalmi élettartam befolyásoló tényezői}

Nordhaus egyik következtetése, hogy fontosabb innovációk esetében (ahol $B$ nagy) az optimális szabadalmi védelmi idő rövidebb kell, hogy legyen, és ahogyan a kérdéses jószág keresletének árrugalmassága növekszik, úgy az optimális szabadalmi élettartalom csökken. Egy rögzített díjas kötelezö licencbe adás soha nem vezethet társadalmi értelemben jobb eredményhez, mint egy egyszerü szabadalmi rendszer (1967, 9. o.). Formalizálva mindezeket, az optimális szabadalmi időre a következő képletet találja Nordhaus:

$$
\varphi(t) \equiv 1-e^{\rho \cdot t}=\frac{d \cdot B+1}{d \cdot B \cdot\left(1+\frac{\sigma}{2}\right)+1}
$$

A képlet alapján ${ }^{16}$ megnézhetjük, hogyan reagál az optimális szabadalmi idő a paraméterek változására: az optimális szabadalmi idő annál kisebb, minél fontosabb innovációról van szó, annál rövidebb, minél nagyobb a kereslet árrugalmassága, illetve minél kisebb $\sigma$ (ami egyébként a tudástermelési függvényben a tudástermelés ráfordítás szerinti rugalmasságának csökkenésével jár). Nordhaus becsléseket is ad az optimális

\footnotetext{
${ }^{14}$ Ha a költségcsökkentés kellően nagy mértékủ, legalább akkora, hogy a 2.1. ábrán az OH szakasz kétszerese az OG szakasznak, akkor drasztikus innovációról beszélhetünk. Ekkora költségcsökkentés lehetỏvé teszi az innovátor számára, hogy monopóliumként tevékenykedve növelje a piacra vitt mennyiséget, és alacsonyabb áron kínálja, mint a magasabb költséggel termelő versenytársai. Ennél kisebb költségcsökkenést jelentö innováció esetében viszont a legjobb, amit tehet, hogy ugyanolyan áron értékesít, mint a többiek, csak alacsonyabb költséggel, vagy a költségcsökkentés mértékének megfelelő díjért mindenkinek licencbe adja a találmányt. Mindkét esetben az elérhető legnagyobb profit az ADCB négyszög (Nordhaus 1967).

${ }^{15}$ Az előbbire Nordhaus az „innováció fontossága” néven hivatkozik, ez valójában $B$ értékét jelenti, az utóbbi pedig ennek a „feltalálási lehetőség függvénynek” a görbületére utal (Nordhaus 1967, 8. o.).

${ }^{16}$ A képletben $\sigma=-\frac{B^{\prime \prime} B}{B^{\prime 2}}$, vagyis a $B$ függvény görbületének mértéke, $\rho$ a diszkontráta és $d$ a keresleti függvény meredeksége.
} 
szabadalmi időtartamra a fenti képlet alapján. $d$ értékét 1-nek véve (egyfajta átlagosan rugalmas piaci kereslettel számolva), $\rho$-t pedig 0,2-nek (20\%-os piaci kamatláb), ha $\sigma=9$ (a tudástermelési függvény által meghatározott), akkor az optimális élettartam a találmány fontosságától függően változhat, , 27 év nagyon triviális találmányok esetében $(B=0,001)$ és 1,5 év a legfontosabbak esetében $(B=1,0)$ " (Nordhaus 1967, 28. o.). A tanulmány megírása idején az Egyesült Államokban a szabadalmi védelem hossza egységesen 17 év volt.

A modellel kapcsolatban felvetődnek kiegészítési lehetőségek, a legfontosabb közülük a szabadalmi védelem szélessége. A szélességet Nordhaus úgy definiálja, mint az innováció költségcsökkentő hatásának az a hányada, amely spilloverként megjelenik más vállalatoknál költségcsökkenés formájában. ${ }^{17} \mathrm{Ha}$ a szélesség nulla, akkor az egész költségcsökkenés átszivárog, és ha egy, akkor az innováció mások költségét semennyire nem csökkenti (tulajdonképpen ez a szélsőséges eset az eredeti modell). A szabadalmi szélességről azt találja, hogy teljesen hasonlóan müködik a szabadalmi élettartammal, annak helyettesítő eszköze lehet a szabadalmi szabályozásban. Szabadon változtatható élettartam esetén ha a szabadalmi idő hosszabb, akkor a szélességnek kisebbnek kell lennie, ha viszont rövidebb, akkor nagyobbnak. Mivel azonban a szabadalmi idő rögzített, és nem változik innovációról innovációra, egy elöre beállított átlagos $t$ időtartam mellett a szélességnek a fontosabb innovációk esetében kisebbnek, a kevésbé fontosak esetében nagyobbnak kellene lennie. A szabadalmi védelem szélességének kérdését a későbbi modellek extenzíven kidolgozzák.

Egy másik problémája Nordhausnak, amelyet maga még csak érintés szintjén tárgyal, de utódainál formalizálva is megjelenik, a szabadalmi verseny, vagyis hogy nem feltétlenül csak egy vállalat dolgozik egy szabadalmon egyszerre. Ekkor a „győztes mindent visz”féle szabadalmi védelem esetében az erőfeszítések fölösleges duplikálódása lehet az eredmény. Ezt a társadalmi szintü veszteséget is ki kellene a szabadalmi rendszernek küszöbölnie valahogyan.

Nordhaus további két problémája azzal kapcsolatos, amit már az elején egyszerűsítési feltételként kikötött: hogy a jelenbeli és a jövőbeli innovációk között igenis fontos, de tisztázatlan globális és lokális interdependenciák vannak. Egyszerüen fogalmazva az interdependenciák az ő szóhasználatában lehetnek lokálisak abban az értelemben, hogy egy innovátor megkönnyítheti az őt követő feltalálók munkáját, mert ad egy alapot, amit

17 Erre a szélesség-definícióra látszik rímelni Romer (1990) kizárható és nem kizárható tudás megkülönböztetése. 
fejleszteni lehet, és globálisak abban az értelemben, hogy az innovátor megnehezítheti az őt követő feltalálók munkáját azáltal, hogy hamarabb kitalálja, amin ők dolgoztak vagy dolgozhatnának. Ez a két probléma az utóbbi évtizedben kiterjedt figyelmet kapott a kutatók részéről, a lokális interdependenicákat a szekvenciális (azaz időben egymást követő, egymásra épülő kutatások) innovációk, a globális interdependenciákat pedig a szabadalmi verseny (többen versenyeznek ugyanazért a szabadalmaztatható innovációért) témakörének a szabadalmi védelem intézményrendszerével kapcsolatosan vizsgálták.

\subsection{A modell változatai: új koncepciók és paraméterek}

Nordhaus modellje az optimális szabadalmak elméletének kiindulópontja lett, és az elkövetkezendő évtizedekben számos kiegészítést végeztek rajta. Ezek a kiegészítések, vagy változatok részben pontosítani, újraértelmezni vagy általánosítani akarták az eredeti modellt (pl. Scherer 1972), vagy újabb elemekkel egészítették ki, amelyek a szabadalmi rendszeren keresztüli gazdaságirányításban segítségül lehetnek (szabadalmi verseny: Denicoló 1996, vagy költséges imitáció: Gallini 1992), vagy a szabadalmi rendszer lehetséges fejlődési irányait kutatták (Hopenhayn és szerzőtársai 2006). A modellváltozatok közös pontja a szabadalmi védelem időtartamának fontossága. Az alábbiakban a Nordhaus-modellből kiinduló modellváltozatok két fontosabb csoportját szeretném felvázolni, néhány példával illusztrálva a közöttük lévő legfontosabb különbséget. A két csoportot az alapján állítottam fel, hogy a szabadalmi védelem miatt a termékpiacon, vagy az innovációk (végső soron: a szellemi termékek) piacán elöálló versenyhelyzetre koncentrálnak-e.

\subsubsection{Verseny a termékpiacon}

A szabadalom, még ha optimális is a nordhaus-i értelemben, monopóliumot állít elő a termékpiacon. A találmány következtében a szabadalom tulajdonosa egy alacsonyabb költségű monopol előállítója lesz a termékének. A tökéletes versenyző kiindulóponthoz képest tehát az egyik szereplő extra piaci hatalomra tesz szert, és ez a versenytársakat automatikusan relatív versenyhátrányba hozza. Az innovátor számára természetesen pont ez jelenti az ösztönzést a kutatás-fejlesztés végrehajtására. A profit csökkenése miatt azonban a versenytársak megpróbálnak módot találni arra, hogy a szabadalom birtokosának monopol hatalmát „megkerüljék”, távolabbi helyettesítőket vezetnek be a piacra, azaz termékdifferenciálást hajtanak végre, vagy egészen közeli helyettesítőkkel szállnak versenybe, vagyis imitálják az innovátort. Mindezeket a reakciókat a szabadalom 
intézménye hívja elö, ezért a szabadalmi védelmi rendszer testreszabásánál, annak társadalmi hatásainak vizsgálatánál e lépéseket figyelembe kell venni.

Az alábbiakban a termékpiaci verseny három fajtáját bemutató modelleket vizsgálom meg: a térbeli termékdifferenciálás, a költségmentes, illetve a költséges imitációt, és ezek hatásait az optimális szabadalmomra.

\section{Szabadalmi szélesség és térbeli termékdifferenciálás}

A termékdifferenciáló megoldásnak az optimális szabadalom „alakjára” gyakorolt hatását vizsgálja Klemperer (1990) cikke. Az optimális alak, szabadalmi design két eleme, a szélesség és a hossz nem egyenrangúak, mint Nordhausnál, hanem Klemperer a szélességnek nagyobb jelentőséget tulajdonít. Ennek alátámasztásául az úgynevezett ekvivalencia-doktrínából indul ki, amely azt mondja ki, hogy ha egy termék ugyanolyan funkciót lát el, mint egy másik, szabadalmazott termék, akkor az előbbi megsértheti ez utóbbinak a szabadalmi jogait. Modelljében a vállalatok termékvariánsokat gyártanak, és minél szélesebb egy szabadalom, a (tökéletesen versenyző) versenytársak az ekvivalenciadoktrína érvényesülése miatt a szabadalom megsértése nélkül csak annál távolabbi helyettesítőket termelhetnek. Modelljében ez a távolság tényleges fizikai távolság formáját ölti, és így szállítási költségekkel növeli meg az egyes termékváltozatok árát. A szabadalmak szélessége kétféle veszteséget okozhat a társadalomnak. Egyrészt ha a szabadalom miatt a fogyasztók kénytelenek kevésbé preferált termékváltozatot vásárolni, pusztán azért, mert azt versenyző körülmények között (alacsonyabb áron) állítják elő, másrészt ha a szabadalom miatt egyes fogyasztók egyáltalán nem vásárolnak inkább a termékből. A széles szabadalom csökkenti az első fajta veszteséget, hiszen szükülnek a választási lehetőségek, ugyanakkor növelik a második fajtát. A szabadalmak optimális szélességének meghatározásakor e két hatás egyensúlyát kell elérni. A szabadalom szélessége azt befolyásolja, hogy az innovátor egy egységnyi profitjára hány egység holtteher-veszteség esik. Első lépésként az optimális szabadalmi szélesség beállításával azt kell tehát elérni, hogy a társadalom szempontjából leghatékonyabban generáljunk profitot az innovátornak. Ezután, második lépésként, a szabadalmi idő meghatározásával felskálázható ez a profit az innovációt ösztönző kívánt nagyságúra. Eredményül Klemperer azt találja, hogy ha a szállítási (utazási) költségek minden fogyasztónál egyformák, akkor a lehető legkisebb szélességü, és végtelen élettartamú szabadalmak lesznek optimálisak. Ha azonban a fogyasztók rezervációs árai egyformák, akkor végtelen (maximális) szélességü, rövid élettartamú szabadalmak lesznek optimálisak. ${ }^{18}$

18 Számos további modell létezik, melyben a térbeli termékdifferenciálás és a szabadalmak összekapcsolódnak, például Poddar - Sinha (2004) vagy Matsumura - Matsushima (2008). Ezekben azonban a kulcsváltozó nem a szabadalmi intézményrendszer optimális tulajdonsága. 


\section{Szabadalmi szélesség és költségmentes imitáció}

Gilbert és Shapiro (1990) cikkükben Klempererrel ellentétben a termékpiaci versenynek azt a fajtáját vizsgálják, ahol közeli (tökéletes) helyettesítővel jelenthetnek meg a versenytársak olyan formában, hogy imitálják az innovátor termékét. A másfajta verseny feltételezésével ők pontosan ellentétes következtetésre jutnak, mint Klemperer: szerintük kis szélesség de végtelen élettartam az optimális.

A szabadalom szélességét úgy definiálják, mint egyfajta piaci hatalom az árak meghatározására, vagyis a szabadalom élettartama alatti profit-áramok nagysága az innovátor számára. A szabadalom szélességének, az innovátor monopol piaci hatalmának növelése növekvő mértékben költséges a társadalom számára, a keletkező holtteherveszteség miatt. Az élettartam növelése azonban mindig állandó mértékü társadalmiköltség-növekedést eredményez, a disztkontrátának megfelelően. Ebből kifolyólag Gilbert és Shapironál a innovációt ösztönző jutalom előállításának hatékony módja az élettartam növelése: a kis szélesség hatékonyan véd az imitáció ellen, a végtelen élettartam pedig konstans mértékü társadalmiköltség-növekedés mellett teszi lehetővé a megfelelő ösztönzést nyújtó jutalom elérését. A konklúziójuk Klempererétől való eltérésének oka, hogy a szabadalom szélessége náluk nem hat a helyettesítő termékekre, mivel homogén terméket feltételeznek. Az innovátort fenyegető veszély az, hogy tökéletes imitációk jelennek meg, amennyiben az általa meghatározott túl magas monopolár elegendő ösztönzés erre.

\section{Szabadalmi szélesség és költséges imitáció}

Gallini (1992) cikkében annak a lehetőségét veti fel, hogy a szabadalmazott terméknek az imitációk költséges, de tökéletes helyettesítői. Amennyiben fennáll a tökéletes helyettesítők megjelenésének veszélye, ez a szabadalom optimális idejét kellően le kell rövidítse ahhoz, hogy ne történhessen imitáció. A csökkenő szabadalmi idő kívánatos a társadalom számára is, ugyanakkor csökkenő ösztönzést nyújt az innovációra. Éppen ezért szükséges egy másik gazdaságirányítási eszköz, a szabadalom szélessége. A szabadalom szélességét ő is, Gilbert és Shapirohoz hasonlóan, az innovátor által a szabadalmi védelmi idő alatt elsajátított flow profitokkal azonosítja. A szabadalom szélessége alkalmas eszköz arra, hogy segítségével megakadályozzuk a költséges (és társadalmilag pazarló) imitációk elóállását, és a szabadalmi védelem hossza pedig beállítja a kívánatos nagyságúra az innovációra ösztönző jutalmat. Gallini tehát a nagy szélességü és rövid szabadalmak mellett érvel. Ez az eredménye ugyanakkor ellentétes a fenti kettő 
következtetéstöl. Az elétérés oka Gallini meglátása szerint az, hogy a fenti modellekben az imitáció, ha már egyszer a szabadalom szélessége beállíttatott, semmilyen hosszú idő alatt nem következik be, nála azonban rögzített szélesség mellett is a szabadalom növekvő hossza növekvő ösztönzés az imitációra. A költséges imitáció realisztikusabb feltételezését követi később a szakirodalom, például Takalo (1998) és Wright (1999). A költséges imitáció mindegyiküknél a szélesebb de rövid szabadalmak irányába mutat.

\subsubsection{Verseny az innovációk piacán}

A szabadalmi védelem monopol helyzethez juttatja az innovátort, így előnybe kerül a termékpiaci versenytársaival szemben. A sikeres innovátor ugyanakkor megnyeri a magáért az innovációért a potenciális innovátorokkal folytatott versenyt a szabadalom megszerzésével. Az innovációs piacon folyó versenynek is több formája jelent meg különböző modellekben, melyeket szeretnék bemutatni: az egylépcsős szabadalmi versenyt, a többlépcsős szabadalmi versenyt és a szekvenciális innovációk modelljét. Egy negyedik részben a szabadalmi versenyt kezelő alternatív megoldásokat szeretném megemlíteni.

\section{Az egylépcsős szabadalmi verseny}

A szabadalmi verseny esetében (Denicoló 1996) arról van szó, hogy a vállalatok versenyben állnak egymással a lehetséges innovációk piacán is, vagyis hogy egyidejüleg több vállalat is kutathatja ugyanazt a találmányt. Ebben az esetben, mivel csupán az egyikük lehet az első, aki megkapja a szabadalmat, de a dollárárveréshez hasonlóan a vesztes is majdnem a teljes árat megfizeti az innovációs költségekben mérve, ez a társadalom számára veszteséges ún. duplikációs költség.

Az innováció megfelelő szintjének eléréséhez az ösztönzőknek egy bonyolultabb rendszerét kell figyelembe venni az optimális szabadalmi szabályozás megalkotásánál. Az egy innovátoros modellekben az egyetlen ösztönzés a kutatás-fejlesztésre az előálló tudás birtokosaként elsajátítható profit volt. Denicoló ezt nevezi „profit-ösztönzőnek”. Amennyiben azonban több cég kutat párhuzamosan egy találmány után, akkor az ösztönzésnek egy újabb elemeként megjelenik az attól való félelem, hogy én magam költségeket vállalok, de valamely másik vállalat szerzi meg a szabadalmat és vele együtt a monopol piaci hatalmat, én pedig a költségeim ellenére hátrányosabb, versenyző pozícióba kerülök. Denicoló ezt „kompetitív fenyegetés”-nek nevezi (Denicoló 1996, 255. o.). A 
kompetitív fenyegetés erőssége attól függ, hogy a győztes mennyire kerülhet előnybe a vesztesekkel szemben, vagyis hogy a vesztesek mennyire tudják visszanyerni a kutatásba beleölt költségeiket későbbi magasabb (természetesen a győztes innovátorénál alacsonyabb) profitok formájában: Denicoló ez alapján definiálja a szabadalom szélességét. A szabadalom szélessége hatással van mind a győztes profitjára, mind a vesztesekére, ezáltal a társadalmi jólétre valamint az innovációs ösztönzésre is. ${ }^{19}$ Ha a társadalmi jólétet a szabadalmi szélesség csökkenő ütemben csökkenti, az innovációs ösztönzőt pedig csökkenő ütemben növeli, akkor a maximális szélesség és egy meghatározott minimális hosszúság optimális. Amennyiben viszont a társadalmi jólét a szabadalmi szélességben növekvő ütemben csökken, és az ösztönző növekvő ütemben nő, minimális meghatározható szélesség és végtelen élettartam lesz optimális. Megállapításai között Denicoló bemutatja, hogy az általam fentebb bemutatott három modell eredményei az ő általános modelljének határesetei (Denicoló 1996, 263. o.). Minél kevésbé hatékony a versengés a termékpiacon, annál valószínübb, hogy a társadalmilag hatékony szabadalom széles de rövid élettartamú.

A szabadalmi versenynek a Denicoló-féle modelljében a verseny vesztesei is vissza tudták nyerni befektetéseik legalább egy részét. Ha azonban a vesztes egyáltalán nem tudja a versengésre fordított erőforrásait visszaszerezni, akkor ez a „győztes mindent visz” szabály (Loury 1979) túlhajtott versengéshez vezethet: a szereplők inkább a maximális, mint az optimális erőfeszítésre törekszenek a veszteségektől való félelmükben (Hámori 2005).

\section{Verseny több lépcsőben: az újítás újítása}

Denicolónak a kétlépcsős szabadalmi verseny modellje (2000) egy újabb koncepcióval bővíti a szabadalmak elméletét: a visszatekintő és az előretekintő védelem fogalmaival. A visszatekintő védelem a már előállított tudás előállítóját védi az imitátorokkal szemben, és a tudáselemet mintegy saját jogán igyekszik jutalmazni. Az előretekintő védelem esetében azt is jutalmazzuk a tudás előállítója felé, hogy az ő innovációja további kutatások elött nyitja meg a kaput. ${ }^{20} \mathrm{~A}$ második lépcső az eredeti szabadalmon történő javítások potenciális szabadalmaztatásáért folyó verseny lépcsője. A

\footnotetext{
${ }^{19}$ A győztesek profitja a szabadalmi szélességben növekvő, a veszteseké pedig csökkenö. Ilyen módon a társadalmi nyereség csökkenő, az innovációs ösztönzés (a profit-ösztönző és a kompetitív fenyegetés együttese) azonban növekvö a szabadalmi szélességben.

${ }^{20}$ Ez már említés szintjén Nordhausnál is megjelent, mikor a lokális és globális interdependenciákról beszélt a kutatás-fejlesztés során.
} 
modellben a döntő fontosságú immár az előretekintő védelem mértéke. Ezt a modell úgy definiálja, mint az első lépcsőben győztes feltalálónak a tárgyalóerejét. Szélsőséges esetben vagy maximálisan erős ez a tárgyalási pozíció, és akkor az első szint győztesének joga van elsajátítani a második szinten győztes találmány összes hasznát, vagy minimális erősség esetében a második találmány hasznaiból az első lépcső győztese semmit nem kap. Az első eset plusz ösztönzés az első lépcsőben, de negatív ösztönzés a másodikban, míg a második eset éppen fordítva. A modell tanulsága szerint az elöre tekintő védelem optimális nagysága a két tudáselem egymáshoz képesti relatív profitabilitásától, költségességétől és a nem elsajátítható hasznosságától (lényegében a holtteher-veszteségtől) függ. Annál erősebb előretekintő védelem kívánatos társadalmi szempontból, minél profitabilisabb, minél kevésbé költséges és minél kisebb a nem elsajátítható érték a második lépcső esetében, az elsőhöz képest. A modell fő változója itt azonban az előretekintő védelem erőssége, és konstans szabadalmi időtartamot feltételez.

\section{A szekvenciális innováció modellje}

A kétlépcsős szabadalmi verseny modellje átvezet az innovációs piacon történő versenyzés egy realisztikusabb modelljéhez, amikor is egy kezdeti találmányon folyamatos javításokat, módosításokat, potenciálisan szabadalmaztatható fejlesztéseket hajtanak végre: ez a szekvenciális innovációk esete. Amikor egy kezdeti találmány egy egész későbbi kutatási irányt jelöl ki, akkor a feladat az, hogy „,a korai innovátorokat teljes mértékben meg tudjuk jutalmazni a technológiai alapokért, amelyeket az őket követő innovátorok elött raknak le, miközben a későbbi innovátorokat is megfelelőképpen jutalmazzuk a nekik köszönhető fejlesztésekért és új termékekért” (Scotchmer 1991, 30. o.).

Az idézett cikkben a szekvenciális innováció jelenségét is figyelembe vevő optimális szabadalom megalkotásakor a szabadalom szélessége hivatott arra, hogy a korai innovátorokat védje a „származékos termékek” versenyével szemben. Scotchmer megjegyzi egyrészt, hogy ez a szabadalmi védelem, vagyis a tudásból származó többletprofit szűkös jószág, amelyet intertemporálisan, különböző generációk között kell elosztanunk. A szükösségből adódóan vagy a korai innovátorokat jutalmazzuk vele, és a későbbieket pedig demotiváljuk, vagy fordítva. Megjegyzi azt a fontos momentumot is, hogy a gazdaságszabályozó hatóság nem rendelkezik megfelelő információkkal a $\mathrm{K}+\mathrm{F}$ projektek költségeit és hasznosságát illetően, ezért az egységesen minden feltalálóra vonatkozó szabadalmi rendszer szükségszerüen nem lesz hatékony. 


\section{Alternatív módok az innovátorok jutalmazására}

Már Wright-nál (1983) megjelenik az az ötlet, hogy a szabadalmi rendszer nem az egyetlen, de még csak nem is biztos, hogy a legjobb módszer az innovátorok jutalmazására: díjak illetve kutatási megbízások lehetnek például az alternatívák. Hopenhayn et al. (2006) egy másik alternatívát, a kivásárlási rendszerrel kibővített szabadalmi rendszert javasolja. A feladat a szabadalmi rendszer olyan átalakítása, amely a folyamatos fejlesztések mellett megfelelően jutalmazni tudja a hasznos fejlesztéseket, viszont megvédi az eredeti feltalálót a kisebb, lényegtelen változtatások szabadalmaztatásából származó potenciális veszteségtől, miközben a szabadalmi védelem szükös erőforrás mivoltát figyelembe veszi.

A szerzők Scotchmerhez hasonlóan szintén onnan indulnak ki, hogy a kormányzatnak nincsenek megfelelő információi ahhoz, hogy kiválogassák a kellően hasznos innovációkat illetve második, harmadik generációs fejlesztéseket. Ezért egy olyan módszert dolgoznak ki, ahol az innovátorok önmaguk előszürik magukat, hogy csak azok az innovációk részesedhessenek a szükösen osztogatható szabadalmi védelemben, amelyek a társadalom számára elegendően hasznosak. Ez a módszer pedig a kivásárlási rendszer. A kivásárlási rendszer lényege, hogy a találmány rögzített időre szabadalmi védelmet élvez, de úgy, hogy kivásárolható a későbbi potenciális újítók által, méghozzá az eredeti feltaláló által a szabadalom odaítélésekor meghatározott ár ellenében. Minél magasabb árat határoz meg az eredeti feltaláló, az újításnak nyilván annál hasznosabbnak kell lennie, hogy megérje megfizetni ezt az árat. Ugyanakkor a magasabb kivásárlási ár csak a szabadalmi hivatalnak fizetett magasabb kezdeti díj mellett állapítható meg, amelyet pedig az eredeti találmány hasznosságának függvényében határoz meg a racionális innovátor.

\subsection{Következtetések}

Ebben a fejezetben igyekeztem bemutatni az optimális szabadalmak elméletének fejlődését, amely abba az irányba mutat, hogy egyre inkább kezelni tudja a mai korban meghatározó folyamatos innovációk által felvetett problémákat. ${ }^{21} \mathrm{Az}$ elmélet fejlődése közben úgy tűnik, egyre inkább figyelembe veszik a Nordhaus által már a kezdeteknél felvetett és az utóbbi időkben egyre nagyobb jelentőségű lokális és globális extern hatásait a kutatás-fejlesztésnek. A lokális externáliák alatt Nordhaus azt érti, hogy az azonos

\footnotetext{
${ }^{21}$ A fejlödés bemutatása közben szükségszerüen eltekintettem jó néhány egyéb kiterjesztésétől az eredeti modellnek, mint például az üzleti titok versus szabadalmazás kérdése, a bírósági eljárás a szabadalmi jogok elismertetésénél, a business stealing vagy a lead time jelensége.
} 
területen folyó kutatások esetében a tudáselemek közötti rivalizálás nagyobb mértékben csökkentheti a jövőbeli kutatások hatékonyságát, mint amennyire a tudáselemek egymás közötti komplementaritása növeli azt. A globális externáliák esetében egymástól jelentősen különböző területeken folyó kutatások esetében éppen jobban érvényesül a komplementaritás miatti hatékonyságnövekedés, mint a rivalizálás miatti hatékonyságcsökkenés. Scotchmer (1991, 31. o.) megemlíti, de nem vizsgálja meg részletesen, milyen módokon járulhat hozzá az eredeti találmány a jövőbeli innovációkhoz: ha az eredeti találmány nélkül a későbbi nem is jöhetne létre, ha az eredeti találmány a későbbit alacsonyabb költség mellett teszi lehetővé, és ha az eredeti találmány a későbbi létrejöttét változatlan költség mellett időben elörébb hozza. A szabadalmi rendszer optimális formájának kialakításakor illetve az innováció optimális szintjének elősegítésekor mindezen hatások részletesebb figyelembe vételére lenne szükség.

Ha a gazdaságpolitikának a tudástermelés elősegítése a célja, akkor hasonlóan ingoványos talajon kell egyensúlyoznia, mint a versenyszabályozás esetében. Ugyanúgy, ahogy a versenyzők védelme nem egyezik meg a verseny védelmével, az innovátorok védelme sem ugyanaz, mint a tudás maximalizálása. Lehetséges, hogy az innovátorok és feltalálók (jogos) védelme bizonyos szabályozási-intézményi környezetben inkább visszafogja a tudástermelés ütemét, semmint elősegíti azt. Felmerül a Samuelson-féle trade-off gondolata: vajon mekkora részét áldozzuk fel a tortának annak érdekében, hogy igazságosabban osszuk el?

Ugyanakkor a másik szélsőség sem biztos, hogy jobb eredményre vezet. Az innovációk nyilvánosságra hozása hasonlatos a bizalomjátékhoz. Megtehetem, hogy az általam előállított tudást nem monopolizálom, hanem mindenki számára szabadon hozzáférhetővé teszem, bízva abban, hogy az ilyen módon megnövekedett profit bizonyos részét ellentételezésként utólag megkapom. Ha nem csak én magam használom az előállított tudást, hanem mások is, a tudás rekombinatív tulajdonsága miatt nagyobb eséllyel áll elő belőle újabb és újabb tudás, aminek hasznaiból én is részesülhetek. Míg a tudás nyilvánosságra hozatala könnyedén megoldható, az ellentételezés már jóval nehezebben: ha már egyszer hozzájutott a tudáshoz a másik fél, miért fizetne érte. Hogyan ellenőrizhető, hogy az általam rendelkezésre bocsátott tudást ki és mennyiben használta fel, az ötletem értékesnek, termékenynek bizonyult-e? Vajon jobb eredményt érek-e el, ha megtartom magamnak és én használom fel, vagy ha inkább mások számára is felhasználhatóvá teszem, hogy kihozhassák belőle, amit tudnak, és az alapján fizessenek nekem valamennyit? A probléma itt nem a make or buy, hanem a make or sell. Ekkor 
valami kikényszeríthető kötelezettségre lenne szükség arra nézve, hogy mennyit kell utólag fizetni az eredetileg díjmentesen megszerzett tudásért. Egy potenciális lehetőség egyfajta ex ante általános royalty-fizetési megegyezés lehetne a Rawls-féle méltányossági elvek mentén. A szabadalmi védelem kiküszöböli ezt a bizalmi dimenziót. Boldrin és Levine (2005) azt mutatják be, hogy az innováció versenyzői piacon is megvalósulhat, de amennyiben mindenképpen monopoljogokat akarunk adni a feltalálóknak, elképzelhető lenne egy olyan rendszer, melyben nem az első feltaláló kapja meg a szabadalmi jogokat, hanem például aki a legalacsonyabb licencdíjat javasolja.

A szabadalom intézményének ismert hiányosságai ellenére tehát, ahogyan Machlupot idéztem korábban (Machlup 1958), felelőtlenség lenne az intézmény egészét univerzálisan eltörölni. Érdemes azonban minél több tényezőt megvizsgálni, ami befolyásolhatja ezen intézmény társadalmi szempontból értelmezett hatékonyságát. A következő fejezetekben néhány ilyen tényezőre szeretnék rámutatni, és hatásaikat elemzeni: az egyik a fogyasztók nem-exponenciális mentális diszkontálása, a másik pedig a szabadalmi védelmi rendszerek egymással kereskedő országok közötti relatív erősségbeli eltérése. 


\section{A hiperbolikus diszkontálás alkalmazása az optimális szabadalmak elméletére}

A disszertáció 2. fejezetében bemutattam, hogy a szabadalmi védelem intézménye rövid- és hosszú távú jóléti hatások kiegyensúlyozásával, a szabadalmi védelem élettartamának megfelelő meghatározásával érhet el optimális eredményt a tudás termelésének elősegítésében. A gazdaságpolitikai döntéshozók, midőn a szabadalmi védelmi rendszer erősségét és felépítését meghatározzák, időben elnyúltan realizálódó hasznokat és költségeket kell, hogy egymással összevessenek az egyensúly megtalálása, az optimális szabadalmi élettartam meghatározása érdekében. Ebben az összemérésben az idő szerepének kiemelkedően nagy jelentősége van. A neoklasszikus közgazdaságtannak megvan az eszköze az effajta döntések kezelésére: a jelen- és jövőérték-számítás, valamint a nettó jelenérték-szabály. A kísérleti közgazdaságtan oldaláról azonban az ilyen számításoknál alkalmazott exponenciális diszkontálást sok támadás érte. Kísérletek alapján pszichológiailag jobban megalapozott alternatívákat javasolnak az előző fejezetben bemutatott összes modell által használt exponenciális modellel szemben: a hiperbolikus, illetve kvázi-hiperbolikus diszkontálási modelleket. A diszkontálási viselkedés és az a mögött meghúzódó feltevések impliciten ugyan, de rendkívül fontos elemek az előző fejezetben bemutatott modellek esetében. A diszkontálási modell megváltoztatása befolyásolhatja az optimális szabadalmakra vonatkozó gazdaságpolitikai ajánlást.

Ebben a fejezetben a célom kettős. Egyrészt cél, hogy áttekintve a különböző diszkontálási modelleket és azok összefüggéseit, rávilágítsak, hogy különbözőségeik milyen eltéréseket okozhatnak még egyszeri kifizetések jelenértékének összevetésénél is, de még inkább akkor, ha ezeket az alternatív modelleket pénz(jólét)áramok jelenértékének kalkulálására használjuk - mint ahogyan ez az optimális szabadalmak elméletében szokásos. A szakirodalomban eddig nem jelent meg a hiperbolikus és kvázi-hiperbolikus diszkontálási modellek ilyen használata. Másodsorban pedig, az optimális szabadalmak elméletén belül maradva azt kívánom megmutatni, hogy egy nem-exponenciális diszkontálási modell alkalmazásával mennyiben adódik más optimális szabadalmi idő, és ilyen módon más ajánlás a gazdaságpolitika számára. 
Beruházás-gazdaságossági számítások során Irving Fisher (1930) óta a közgazdaságtan által használt normatív döntési szabály, hogy legföljebb azokat a beruházásokat érdemes megvalósítani, amelyek esetében a nettó jelenérték pozitív, vagyis amikor a beruházástól annak hasznos élettartama alatt várható összes nettó pénzáramlás jelenre diszkontált összege nullánál nagyobb. Samuelson (1937) hasonló módon normatív döntési szabályként vezeti be a diszkontált hasznosság elméletét. Később azonban magatartás-gazdaságtani kutatások (Ainslie 1992, Loewenstein - Prelec 1992) rámutattak, hogy a valóságban a döntéshozók az említett, exponenciális diszkontálást alkalmazó modellekkel össze nem egyeztethető módon hoznak intertemporális döntéseket. Magára a diszkontálási viselkedésre koncentrálva döntéseik jobban leírhatóak hiperbolikus (Loewenstein - Prelec 1992) vagy kvázi-hiperbolikus (Laibson 1996) diszkontálást feltételezve.

$\mathrm{Az}$ exponenciális diszkontálást univerzálisan alkalmazva a fogyasztói döntések esetén téves eredményekhez jutunk, viszont a nem-exponenciális diszkontálási modellek a beruházási döntések esetén vezetnek hibás következtetésre. Ha a beruházási döntéseknél az empirikusan megalapozott nem-exponenciális diszkontálást használjuk fel, akkor az ezekben a modellekben megjelenő időbeli inkonzisztencia miatt a mai terveket nem fogjuk követni a jövőben (Cropper - Laibson 1998).

Amellett fogok érvelni, hogy a diszkontálásbeli különbségek miatt bizonyos döntési szituációkban indokolt e kétféle módszer egyfajta „keverékét” alkalmazni. A kormányzat lehet az a szereplö, aki különböző elköteleződési mechanizmusokkal beavatkozhat annak érdekében hogy bizonyos projektekben a fogyasztók nem-exponenciális időbeli preferenciái érvényesülhessenek (Strotz 1956, Cropper - Laibson 1998). Az optimális szabadalmak Nordhaus (1967) által elindított elméletében az állam által meghatározott szabadalmi védelmi idő egy olyan elköteleződés ${ }^{22}$, amely pontosan meghatározza a jövőbeli cselekvési lehetőségeket: a szabadalmi védelem időtartama alatt a feltaláló elsajátíthatja az innovációból származó hasznok egy részét profitként, és csak e védelem lejárta után élvezheti a társadalom többi része a teljes hasznot. ${ }^{23}$ Nordhaus az állam által kijelölendő optimális szabadalmi hosszat az általa vizsgált tényezők függvényében 1 és 34 év közé teszi, míg a valóságban jelenleg az Egyesült Államokban és Európában a tényleges

\footnotetext{
${ }^{22}$ Czeglédi (2009) megmutatja, hogy az innovatív vállalatok számára nem csak az a fontos a tulajdonjogi kockázatuk szempontjából, hogy létezik-e az állam részéről ilyen elköteleződés, hanem az is, hogy az mennyire hihető, vagyis hogy mekkora esélyt látnak arra, hogy az állam idővel meggondolja magát. Az általam vizsgált modellekbe ennek a lehetősége nincsen benne.

${ }^{23}$ A beruházási döntéseknek további ilyen, a fogyasztók nem-exponenciális diszkontálási viselkedését figyelembe vevő területei lehetnek a környezetvédelmi vagy egészségügyi beruházások.
} 
szabadalmi időtartam iparágtól és találmánytól függetlenül, egységesen 20 év. Vajon mennyiben kell máshogyan megállapítani az államnak a szabadalmi védelem hosszát, ha figyelembe veszi a fogyasztók jövőbeli hasznokra és költségekre vonatkozó nemexponenciális diszkontálási viselkedését?

Az 1. alfejezetben áttekintem és csoportosítom a különböző diszkontálási modelleket, rámutatok kapcsolódási pontjaikra, illetve az eltérő modellek használatából eredő jelenérték-számításbeli eredmények különbözőségére. A 2. alfejezetben az első alfejezet eredményei alapján megmutatom, hogy az exponenciális és nem-exponenciális modellek használatából eredő különbségek hatványozottan érvényesülnek akkor, amikor megpróbáljuk egy olyan területen alkalmazni ezeket a modelleket, mint a pénzáramok, annuitások, de főként halasztott örökjáradékok jelenértékének kiszámítása, hiszen például egy innováció időben hosszan elnyúlóan biztosít hozamokat jelenbeli költségek árán. Ismereteim szerint az exponenciális diszkontálási modellekkel versengő alternatív modellek ilyen alkalmazásával még nem foglalkoztak. Ahogy az első alfejezetben, úgy itt is kiszámítom a különböző modellek alkalmazásával előálló különbségeket a jelenértékekben. A 3. alfejezetben a nem-exponenciális diszkontálást az optimális szabadalmak elméletére alkalmazom. Ebben a részben Duffy (2005) egyszerü modellje segítségével mutatom be, hogy a kvázi-hiperbolikus diszkontálás alkalmazása hasznos hozzájárulás lehet egy olyan gazdaságpolitikai változó, mint a szabadalmi védelmi idő megfelelő kialakításánál. Végül a 4. alfejezetben összegzem az eredményeket, és kitekintést adok további alkalmazási lehetőségekre.

\subsection{Az exponenciális diszkontálási modell és alternatívái}

A diszkontált hasznosság modellje (DU - Discounted Utility) Paul Anthony Samuelson 1937-es „A Note on Measurement of Utility” című írásával került be a közgazdasági gondolkodásba, és terjedt el rohamos sebességgel, mint a különböző időpontokban jelentkező hasznosságok összehasonlításának módszere. Azt írja: „bármely tetszőleges időszak alatt az egyén úgy viselkedik, hogy maximalizálja az összes jövőbeli hasznosságnak egy megfelelő időbeli diszkontálással azonos nagyságrendűvé csökkentett összegét. [...] Az egyén a jövőbeli hasznosságokat egy egyszerü és következetes módon számítolja le, mely módszer ismert számunkra.” (Samuelson, 1937, 156. o.) Ez az ismertnek feltételezett módszer pedig a pénz időértékének számításánál használt exponenciális diszkontálás lett. 
Samuelson eredeti értelmezésének megfelelően a diszkontálás vagy leszámítolás fogalmának tág értelmezését magyarázva Rachlin (2006, 425.o) az Oxford Enciclopedic Dictionary bejegyzését idézi, miszerint a diszkontálni szó egyik jelentése: „egy eredeti esemény hatását csökkenteni”. Általános esetben tehát arról van szó, hogy egy eredeti esemény hatása $(X)$ valamilyen együttható $(\delta)$ szerint egy kisebb hatássá $(x)$ mérséklődik. Ez a mérséklődés felírható akár $x=\delta X$, akár $x / X=\delta$ formában. Ez a $\delta$ együttható maga is más változók függvényében lehet nagyobb vagy kisebb, kifejezve, hogy milyen hatásra és milyen mértékben csökken az eredeti esemény hatása. ${ }^{24}$

Samuelson az eredetileg a beruházás-gazdaságossági számítások során a mikroökonómiában szükebb értelemben, jövőbeli pénzösszegek értékének összehasonlítására használt leszámítolást jövőbeli hasznosságok összehasonlítására is kiterjesztette. Általánosságban $X$ egy jövőben megkapható összeget (illetve annak hasznosságát) jelenti, $x$ egy jelenben megkapható összeget (illetve annak hasznosságát), $\delta$ pedig az a szorzótényező, a diszkontfaktor, amely mellett a két előbbi érték a döntéshozó számára egyforma. $\delta$ értékét két tényező határozza meg, a kamatláb, mint exogén paraméter, és az idő múlása, mint változó. Minél több idő telik el a jelen és a jövő között, $\delta_{t}$ értéke annál kisebb, így adott adott jövőbeli összegnek (hasznosságnak) annál kisebb jelenbeli felel meg, vagy adott jelenbeli összegnek (hasznosságnak) annál nagyobb jövőbeli. $\delta_{t}$ értéke szintén fordítottan arányos a kamatlábbal.

Az alfejezetben először tehát az általánosan elfogadott és alkalmazott exponenciális diszkontálási modellel, és az azt ért kritikákkal foglalkozom, melyek nyomán különféle alternatív megközelítések láttak napvilágot. Ezután pedig ezek közül a lehetséges alternatívák közül emelek ki kettőt, a hiperbolikus és a kvázi-hiperbolikus diszkontálási modelleket, és mutatom be őket részletesebben, összevetve őket a diszkonttényező időbeli alakulása szempontjából az exponenciális modellel.

\section{Az exponenciális diszkontálás és kritikái}

Az intertemporális döntések neoklasszikus elmélete a diszkontfaktor alakulását exponenciális módon kezeli. Ekkor a diszkontfaktor az alábbi módon függ az idő múlásától ( $t$ ) és a kamatlábtól $(r)$ :

$$
\delta=\delta_{t}=\frac{1}{(1+r)^{t}} .
$$

\footnotetext{
${ }^{24}$ Például a növekvő távolság csökkenti a vízbe dobott kő által vetett hullámok nagyságát.
} 
A magatartás-gazdaságtani kísérletek azonban rámutattak arra, hogy a tényleges emberi döntéshozatal során a kísérleti alanyok sorra ezzel össze nem egyeztethető döntéseket hoznak, és diszkontálási viselkedésük jobban leírható másmilyen modellekkel. A legismertebb ilyen kísérleti eredmény, anomália, a preferenciafordulás jelensége (Kirby Herrnstein, 1995), amikor az $A$ és $B$ különböző idöpontokban választható alternatívák közötti döntés minden egyéb változatlansága mellett más lesz, ha hamarabb és más, ha később kell dönteni. A fogyasztók intertemporális választásaik során időbeli inkonzisztenciát mutatnak, ami azonban az exponenciális diszkontálás mellett nem fordulhatna elö: ha $A$ jobb választás a $B$-nél, akkor ezt nem változtathatja meg az, hogy most vagy később kell választani közöttük. Ezzel az időbeli (vagy más néven dinamikus) inkonzisztencia-jelenséggel kapcsolatos a halogatás-probléma (Laibson, 1997): idén úgy gondolom, hogy racionális kalkulációk alapján megéri nekem jövőre elkezdeni erőteljesen takarékoskodni, de mikor a következö év eljön, mégsem teszem ezt, hanem elhalasztom egy évvel, nem látván előre, hogy egy év múlva is éppen így fogok gondolkodni. ${ }^{25}$

Többféle lehetséges magyarázat is született ezekre a jelenségekre. Ezek egy része, amelyekkel itt most foglalkozni szeretnék, a diszkontálási modellt változtatja meg. Ilyenek például a szakirodalom által hiperbolikus diszkontálásnak (Loewenstein - Prelec 1992), illetve kvázi-hiperbolikus diszkontálásnak (Phelps - Pollak, 1968) nevezett modellek. Ezen alternatív modellek igyekeznek a neoklasszikus diszkontálási modellbe beépíteni a kísérleti közgazdaságtan tanulságait, vagyis azt, hogy az idő múlása nem csak a diszkontfaktort csökkenti folyamatosan, hanem befolyásolja a diszkontrátát is. ${ }^{26}$ Egy időben változó diszkontrátával diszkontáló modell különböző módokon formalizálható, különböző szerzők eltérő függvényekkel próbálják az ilyen módon diszkontáló viselkedést leírni. Az ilyen módon diszkontáló nem-exponenciális diszkont-függvényeket döntési szabályként

\footnotetext{
${ }^{25}$ Az időbeli inkonzisztenciával magyarázható a fogyasztók halogatásra hajlamos viselkedése. A halogatásra hajlamos fogyasztóknak döntéseik során gyakran önkontrollt kell gyakorolniuk, hogy elkerülhessék az időbeli inkonzisztenciából fakadó, néha maguk által is felismerten nem-racionális döntést. A halogatással és ezzel összefüggésben a fogyasztói önkontrollal kapcsolatban egy jó áttekintést ad Lippai (2010).

${ }^{26}$ Számos további modell is létezik az említett jelenségek magyarázatára. Ezek közül itt azt a csoportot emeltem ki, amely az exponenciálishoz hasonlóan konkrét függvényformát ad az általa leírt diszkontálási viselkedésnek. Frederick et al. (2002) kimerítően áttekinti és csoportosítja az alternatív magyarázó elméleteket. Az ebben a cikkben is megemlített szubadditív modell, bár részben matematizált, nem ad meg az általam vizsgáltakhoz hasonló explicit diszkontfüggvényt (bővebben lásd Read 2001). Trope és Liberman (2003) a preferenciafordulás jelenségére olyan magyarázatot ad, amely pszichológiai tényezőket attitüdöket, érzelmeket, kogníciókat - használ magyarázó tényezőkként, ám ezek még kevésbé matematizáltak.
} 
használva más eredményeket fogunk kapni, mintha optimalizáló gazdasági alanyainkról exponenciális diszkontálást feltételeznénk.

Az időben csökkenő diszkontrátát alkalmazó modelleket felfoghatjuk úgy is, mint az exponenciális modell általánosításait. Az egyik irányzat abba az irányba általánosít, hogy míg az exponenciális modellben egy tetszőleges időben $\delta_{t}=\delta^{t}$ a diszkonttényező, ez általánosítható $\delta_{t}=\beta \delta^{t}$ formában - ez a diszkrét kvázi-hiperbolikus, vagy más néven béta-delta diszkontfüggvény. E szerint az irányzat szerint az eltérést az első időszak különösen erőteljes diszkontálása okozza. A másik irányzat pedig abba az irányba általánosít, hogy az exponenciális modellhez képest az általánosított modellben $\delta_{t}=\delta^{\alpha(t)}$ - ez a folytonos hiperbolikus diszkontfüggvények csoportja. Ez az irányzat az eltérést az „idő téves érzékelésével” magyarázza. Látható, hogy ezen általános képletekből a diszkontálási paraméterek megfelelő megválasztásával határesetként előállítható az exponenciális modell.

\section{A hiperbolikus diszkontálási modell}

Tekintsük először a folytonos hiperbolikus diszkontálási modelleket! Cairns (2006) az Albrecht és Weber szerzőpáros összehasonlítását idézi az exponenciális és a hiperbolikus diszkontálási modellek között. A hagyományos exponenciális diszkontálási modell eszerint az alábbi képlet szerint általánosítható:

$$
\frac{x}{X}=\delta_{t}=\frac{1}{(1+r)^{\alpha(t)}} \text {. }
$$

Ez az általánosítás azt állítja, hogy a diszkontfaktor függ a kamatlábtól és az időtől, de nem az idő tényleges múlásától, hanem az idő múlásának észlelésétől - ez az a tényező, melyet a képletben $\alpha(t)$, az idő-észlelési függvény (time perception function (Cairns 2006, 283.o.)) jelöl. ${ }^{27}$ Ezt a téves időészlelést jövőre tekintő módon kell értelmeznünk, vagyis inkább az előttünk lévő idő téves észleléséről, kezeléséről, értékeléséről van szó, semmint az elmúlt időéről.

A hagyományos exponenciális modell szerint a gazdasági alanyok pontosan úgy észlelik az idő múlását, mint ahogyan az a valóságban múlik. Ekkor $\alpha(t)=t$. Valójában nincs okunk feltételezni, hogy a gazdasági alanyok pont így viselkednének, mint ahogyan

\footnotetext{
${ }^{27}$ Albrecht és Weber a $\delta_{t}$ tényezőt döntési súlynak nevezi, utalva ezzel arra, hogy a diszkontfaktor ugyanazt a szerepet tölti be az intertemporális döntések esetén, mint amit a bekövetkezési valószínüség a kockázatos döntések elméletében.
} 
azt sem, hogy nem, de egyfajta viszonyítási alapnak ez a feltételezés kiválóan megfelel. Annál is inkább, mert a bankrendszer a kamat, illetve kamatos kamat számításánál ezt a képletet használja, így a bankba tett pénz után a várakozásért pontosan annyi kompenzációt nyújt az embereknek, mint amennyit akkor kell(ene) kapniuk, ha a valódi sebességén észlelik/észlelnék az idő múlását. Ha tehát egy gazdasági döntéshozó valamilyen oknál fogva ettől különböző gyorsasággal múlónak érzékeli (mentálisan), vagy inkább kezeli az időt, akkor a bank által ajánlott kamat őt vagy túl- vagy alul fogja kompenzálni a várakozásáért, ex ante. $\mathrm{Az}$ exponenciális képlet általánosításaként a hiperbolikus diszkontálási modellek éppen ilyen torzult időérzékelésre mutatnak példát. ${ }^{28}$

Loewenstein és Prelec (1992) a kísérletekben az intertemporális választások során megfigyelt anomáliákat úgy igyekeztek magyarázni, hogy a diszkontfüggvényt módosították. Elméleti levezetésük alapján a különböző, exponenciális modellel össze nem egyeztethető választások akkor értelmezhetőek, ha „a diszkontfüggvény egy általános hiperbola" (Loewenstein - Prelec 1992, 580. o.):

$$
\delta_{t}=\frac{1}{(1+g t)^{h / g}}, \text { amit akkor kapunk, ha } \alpha(t)=\frac{h \ln (1+g t)}{g \ln (1+r)},
$$

Ezen kívül még két további hiperbolikus diszkontfüggvényt érdemes megemlíteni. Mazur (1987) modelljében a diszkontfaktor

$$
\delta_{t}=\frac{1}{1+g t}, \text { az ehhez szükséges helyettesítés } \alpha(t)=\frac{\ln (1+g t)}{\ln (1+r)},
$$

Harvey (1995) modellje szerint pedig

$$
\delta_{t}=\frac{1}{(1+t)^{h}} \text {, amihez a megfelelő helyettesítés az } \alpha(t)=h \frac{\ln (1+t)}{\ln (1+r)} .
$$

Mindegyik fenti $\alpha(t)$-ről megmutatható, hogy $t$ szerint növekszik, tehát minél több idő telik el a valóságban, a döntéshozók is úgy észlelik, hogy több idő telik el. Mindegyik diszkontfaktor $t=0$ esetén 1 értéket vesz fel, vagyis a döntéshozók a diszkontálási viselkedéstől függetlenül a 0 időt 0 időnek érzékelik.

\footnotetext{
${ }^{28}$ Bár $\alpha(t)$-t az időészlelés torzulásaként vezettem be, a Loewenstein - Prelec, Mazur, és Harvey modelljeihez tartozó lentebbi $\alpha(t)$ összefüggések szerint viszont ezt egy a gazdasági döntéshozón kívül álló gazdasági tényező is befolyásolhatja: a kamatláb. Pszichológiai szempontból ugyanakkor irreális az a gondolat, hogy az unokáit hazaváró nagymama számára (vagy éppen egy fogyasztó számára, aki a szabadalmi védelem lejárta után megnövekedett fogyasztói többlethez juthat) gyorsabban vagy lassabban telne az idő pusztán a kamatláb megváltozása miatt. Pontosabb tehát az $\alpha(t)$-re úgy hivatkozni, mint ami azt írja le, hogy egy exponenciálisan diszkontáló aktor időészlelését hogyan kellene eltorzítani ahhoz, hogy úgy viselkedjen, mint az általunk vizsgált aktorok. Az alábbiakban $\alpha(t)$-t ebben az értelemben fogom torzult időérzékelésnek nevezni.
} 
Ha bevezetjük a $-\frac{\delta_{t}^{\prime}}{\delta_{t}}$ képlettel számítható $t$ időpontbeli pillanatnyi diszkontráta fogalmát, akkor megragadható a növekvő türelem jelensége. Ez az érték exponenciális esetben $t$-töl független állandó, míg a hiperbolikus esetekben $t$-ben csökkenő. ${ }^{29}$ Ebböl ered a modellek nevében a „hiperbolikus” kitétel.

Az említett képletek közül a legáltalánosabb a Loewenstein - Prelec képlet, a paraméterek megfelelő megválasztásával a másik kettő annak aleseteiként előáll. Az alábbi megállapításokat ezért erre a modellre teszem, de a megfelelő átalakítással érvényesek a többi modell esetére is.

A hiperbolikus modellek általában a következő képet adják az idő észlelése tekintetében (3.1. ábra)

\section{1. ábra. Az idő múlásának észlelése az eltelt idő függvényében}

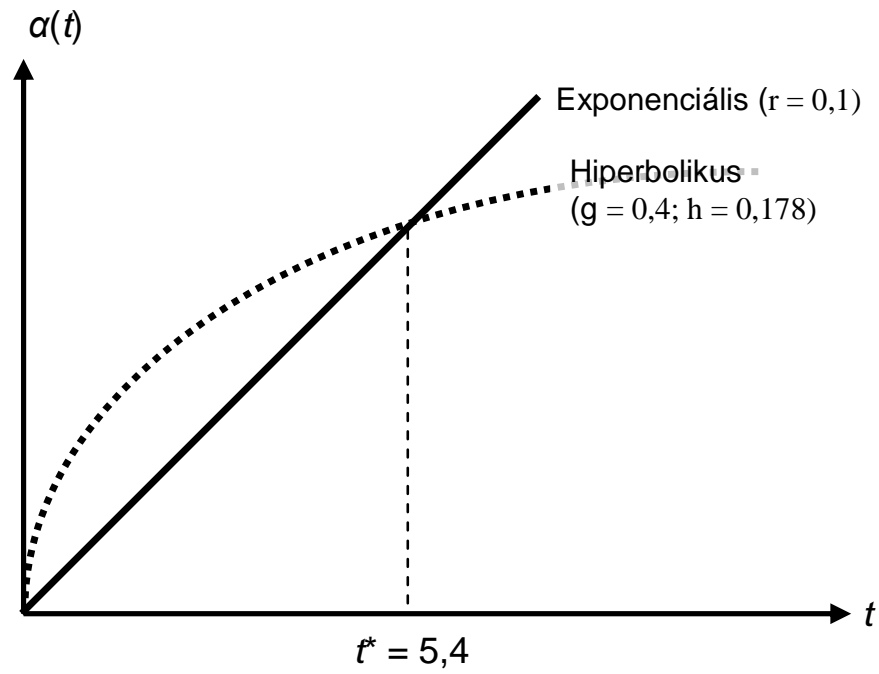

Forrás: saját szerkesztés

Meghatározható az ábrán $t^{*}$-gal jelölt pont, ahol $\alpha(t)=t$, vagy egyszerüen az exponenciális és a hiperbolikus diszkontráta egyenlőségéből:

$$
\frac{1}{(1+r)^{t}}=\frac{1}{(1+g t)^{h / g}} .
$$

A $t^{*}$ időpont elsődleges jelentése, hogy ennél korábbi időpontokban az alanyunk az idő múlását gyorsabbnak értékeli, mint amilyen az valójában, hiperbolikus diszkonttényezője kisebb az exponenciálisnál. A valóságban csak egy évet kell várakoznia, de azt ő kettőként

\footnotetext{
${ }^{29}$ Az exponenciális esetben a $t$ időpontbeli pillanatnyi diszkontrátára így a $-\ln (1 /(1+r))$ konstans adódik, míg a legáltalánosabb Loewenstein-Prelec esetre a $h /(1+g t)$, ami $t$ növekedésével csökken.
} 
értékeli. ${ }^{30}$ Ennek megfelelően a döntéshozó nagyobb kompenzációt vár el, mint amit az exponenciális modell sugall. Hasonlóan, $t^{*}$-nál későbbi időpontokban az idő múlása már a valóságosnál lassabbnak tünik a döntéshozó számára, ezért alacsonyabb kompenzációval is megelégedne a várakozásáért, mint amit az exponenciális modell leír. Ha a banktól exponenciális diszkontálás szerint kap kamatot a várakozásért, akkor tehát $t^{*}$ időpont előtt alul- utána pedig felülkompenzált. A $t^{*}$ értéke természetesen függ a modellünk paramétereitől, ${ }^{31} g, h$ és $r$ értékeitől. Bár analitikus megoldást $t^{*}$-ra ebben az esetben nem tudok adni, annyi bizonyos, hogy a $t^{*}$ értéke $r$-ben csökkenő, $h$-ban növekvő, $g$-ben pedig csökkenő. A 3.1. ábrán az $\alpha(t)$ függvényt $h$ növekedése felfelé nyújtja meg, $g$ növekedése viszont lefelé nyomja össze: ennek megfelelően látható $t^{*}$ változása.

\section{A kvázi-hiperbolikus diszkontálási modell}

Az optimális szabadalmak elméletének kiterjesztésére a jelen fejezetben a kvázihiperbolikus modellt fogom alkalmazni, két okból is. Először is az egyszerüség okán. Ez a függvényforma „visszaadja a hiperbolikus diszkontfüggvények kvalitatív vonását [miszerint a diszkontráta időben csökkenő], miközben megtartja az exponenciális diszkontfüggvény analitikus kezelhetőségét." (Laibson 1996, 8. o.). A második ok összefüggésben áll az elsővel. Laibson megfontolásához hasonlóan más szerzők is ezt a függvényformát alkalmazták, amikor laboratóriumi kísérletekben vagy valós döntések megfigyelésével a döntéshozók által használt diszkontfüggvény paramétereit becsülni igyekeztek, így a szakirodalomban fellelhetők a kvázi-hiperbolikus modell $\beta$ és $\delta$ paramétereire vonatkozó benchmark-értékek, a hiperbolikus modellek paramétereire viszont nem állnak rendelkezésre empirikus becslések. ${ }^{32}$

\footnotetext{
${ }^{30}$ A valóságban ez persze visszatekintve is működhet: „Lehet, csupán elfáradtam, rosszul látom: harminc évnek tủnik három!" - kiált fel Jézus a Jézus Krisztus Szupersztár c. rockoperában. Ez a fajta utólagos időérzékelési-torzulás szempontunkból nem lényeges, mert a jelenbeli döntések meghozatalánál a jövőbeli kültségek és hasznok értékelése fontos.

${ }^{31}$ Már ha egyáltalán létezik ilyen. A $g$, illetve $h$ paraméterek megfelelő megválasztása esetén lehet, hogy a különbözöféleképpen számított $\alpha(t)$ értékeknek csak egy közös pontjuk lesz a $t$-vel, éspedig a $t=0$. Ebben az estben döntéshozónk vagy az időhossztól függetlenül felülkompenzált (ha $\alpha(t)$ végig $t$ alatt halad), vagy épp ellenkezőleg, időhossztól függetlenül alulkompenzált. Bemutatható azonban, hogy az utóbbi eset nem állhat elő: nem létezhet olyan $g$ és $h$ paraméter, amelyek mellett valaki folyamatosan gyorsabban múlónak érezné az időt, mint ahogyan az valójában telik. Az előbbi eset pedig a 3.1. ábra szempontjából azt jelenti, hogy a hiperbolikus görbénk végig az exponenciális alatt halad. Ha például $h<r$, akkor ez a helyzet áll elő: ekkor nincsen metszéspont.

${ }^{32}$ Azokban az elméleti munkákban, melyek szemléletésként egyszerre ábrázolnak egy exponenciális és egy hiperbolikus diszkontfüggvényt, a hiperbolikus esetben a paramétereknek nagyságrendileg különbözö értékeit használják. Csak két példát említve Angeletos et al. (2001) cikkében $g=4$ és $h=1$, míg Laibson (1996) $g=10^{5}$ és $h=5 \cdot 10^{3}$ paraméterértékeket használ!
} 
Az általam használt diszkontálási modell esetében tehát egy tetszőleges időszak diszkonttényezője kiszámítható a $\delta_{t}=\beta \cdot \delta_{h}^{t}$ formában. Ha $\beta=1$, akkor megkapjuk speciális esetként az exponenciálisan diszkontáló modellt. Ha viszont, ahogyan a modell felteszi, $0<\beta<1$, akkor egy diszkrét diszkont-függvényt kapunk, melynek értékei $\left\{1, \beta \delta_{h}\right.$, $\left.\beta \delta_{h}{ }^{2}, \beta \delta_{h}{ }^{3}, \ldots\right\}$. A béta-delta diszkontálás mögött az az elképzelés húzódik meg, hogy a döntéshozó elsősorban az alapján mérlegel, hogy jelenbeli vagy későbbi fogyasztásról vane szó. A nem jelenbeli fogyasztásokat egyből egy erőteljes, $\beta$ mértékben diszkontálja. Attól kezdve viszont, hogy a nem-jelenbeliség miatt elvégezte az erőteljes leszámítolást, már ennél jóval kisebb mértékben befolyásolja az, hogy kicsivel vagy sokkal későbbi fogyasztásról van szó. A modellfeltevés szerinti $0<\beta<1$ a rövid távú erős türelmetlenségre utal. Az első időszak után a jövőt leszámítoló, időben állandó kamatláb a kvázi-hiperbolikus modell esetében a midell feltevése szerint alacsonyabb az exponenciális kamatlábnál, vagyis $r_{h}<r_{e}$ (ahonnan $0<\delta_{e}<\delta_{h}<1$ ). Ez az alacsonyabb kamatláb az exponenciális diszkontáláshoz képest értelmezett nagyobb hosszú távú türelemre utal. A „kvázi-hiperbolikus” elnevezése a modellnek arra utal, hogy a modell átmenet a hiperbolikus és az exponenciális modell között, mivel kezdetben, a 0. és az 1. időszak között mutat csökkenő diszkontrátát, akár a hiperbolikus modellek, onnantól kezdve azonban a diszkontráta időben állandó. ${ }^{33}$

Összevetve egy exponenciális és egy kvázi-hiperbolikus diszkontfüggvényt, a 3.2. ábrán látható képet kapunk. A könnyebb kezelhetőség kedvéért az egyébként diszkrét bétadelta diszkontfüggvény pontjait összekötöttem. Az ábra készítésénél a kvázi-hiperbolikus diszkontfüggvény esetében használt paraméterek az empirikus vizsgálatokból Angeletos et al. (2001) által becsült paraméterértékek. Ezekhez meglepően hasonló értékeket talált egy másik kísérletben Laibson et al. (2007).

A 3.2. ábra azt mutatja, hogy ismét létezik adott paraméterek mellett egy olyan $t^{*}$ időpont, amikor az exponenciális és a kvázi-hiperbolikus diszkonttényező megegyeznek, ennél korábbi időpont esetén a kvázi-hiperbolikus diszkonttényező kisebb az exponenciálisnál, ennél későbbi időpont esetében pedig nagyobb.

\footnotetext{
${ }^{33}$ A $t$ időpontbeli pillanatnyi diszkontráta az első időszakra nézve $-\ln (\beta \cdot 1 /(1+r))$, míg a későbbiekben, akárcsak az exponenciális modellben, $-\ln (1 /(1+r))$ (Laibson et al. 2007, 15. o.)
} 
3.2. ábra. Egy exponenciális és egy kvázi-hiperbolikus diszkontfüggvény

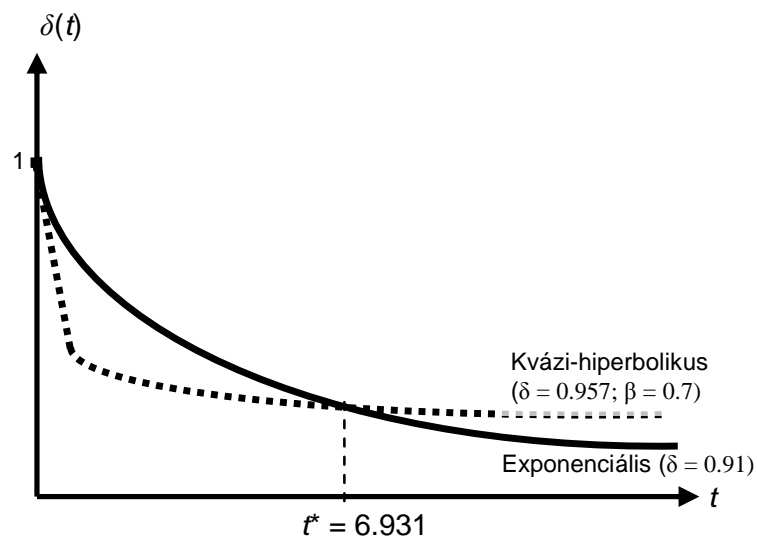

Forrás: saját szerkesztés

Az ábra szerint ha az exponenciális diszkonttényező $\delta_{e}=0,91$ (vagyis a kamatláb $10 \%$, míg a hiperbolikus esetben $\beta=0,7$, és az alacsonyabb hosszú távú kamatlábnak köszönhetően $\delta_{h}=0,957$ (azaz a „kvázi-hiperbolikus kamatláb” 4,5\%), akkor a $t$ * időpont 6,931 évnél található. Ekkor egységnyi pénzt 6,931 évnél rövidebb időre lekötve a bankban, a lekötés végén kifizetett összeget kevesebbre értékelné a kvázi-hiperbolikusan diszkontáló egyén, mint a betettet. 6,931 éven túli lekötésnél azonban az exponenciálisan kamatozó betét végső kifizetését értékesebbnek vélné, mint a betett összeget. Az egyén tehát az első 6,931 évben egységnyi jelenbeli pénzért több jövőbeli pénzt kér, mint amennyit a bank adna, illetve egységnyi jövőben kapható pénzt kevesebb jelenbelivel tart egyenértékünek. Ennél rövidebb idő alatt a bank alulkompenzálná a megtakarítót, ennél hosszabb idő esetén viszont felül. ${ }^{34}$

A kétféle módszerrel számított diszkonttényező közötti viszonyt a

$$
\frac{\beta \cdot \delta_{h}^{t}}{\delta_{e}^{t}}=\beta \cdot\left(\frac{1+r_{e}}{1+r_{h}}\right)^{t}
$$

képlet adja meg, ahol $\delta_{e}=\frac{1}{1+r_{e}}$ és $\delta_{h}=\frac{1}{1+r_{h}}$. A zárójelben lévő hányados a $r_{h}<r_{e}$ modellfeltétel miatt egynél nagyobb, vagyis a szorzat második tényezője $t$-ben növekvő. A

\footnotetext{
${ }^{34}$ Bár szemléletes összehasonlítani a gazdasági alany által elvárt hozamot és a bank által ajánlott hozamot, több szempontból sem szerencsés. Egyrészt a nem exponenciális diszkontálás időbeli inkonzisztens voltából fakadóan ez az értékelés csak a jelenböl nézve érvényes. Másrészt, Mulligan (1996) amellett érvel, hogy egy hiperbolikus diszkontáló vagy nem fér hozzá a pénzpiacokhoz, vagy nincs vagyona. Az említett példámban egy arbitrazsőr kockázatmentes nyereségre tehet szert összekapcsolva a kvázi-hiperbolikus diszkontálót és az exponenciálisan diszkontáló bankot. Bár ezt a példát még a 2. alfejezetben is használom a jövedelemáramlások összehasonlítására, a fenti két ok miatt a 3. alfejezetben már csak hasznosságok esetében használom a kvázi-hiperbolikus diszkontálást, pénzösszegek esetében nem.
} 
szorzat, vagyis a két diszkonttényező aránya egynél kisebb vagy nagyobb értéket is felvehet, ahogyan a 3.2. ábrán látszik is.

Megadható az a $t^{*}$ időpont a diszkontálási paraméterek függvényében, amikor a két diszkontfaktor fentebb kiszámított aránya éppen egy, mégpedig

$$
t^{*}=\frac{\ln \beta}{\ln \frac{1+r_{h}}{1+r_{e}}}=\frac{\ln \beta}{\ln \delta_{e}-\ln \delta_{h}} .
$$

Ha $t^{*}$-ot a diszkontálási paraméterek függvényeként értelmezzük, akkor (1) alapján megállapítható, hogy $\frac{\partial t^{*}}{\partial \beta}<0$, továbbá hogy $\frac{\partial t^{*}}{\partial r_{e}}<0$ és $\frac{\partial t^{*}}{\partial r_{h}}>0$, és mivel $r_{h}<r_{e}$, ezért $t^{*}$ a kétféle diszkontráta különbségének csökkenésében is növekvő. A deriváltak alapján látható, hogy a modellben $t^{*}$ úgy reagál $\beta$ és $r_{h}$ paraméterek változására, mint a hiperbolikus modellben $g$ és $h$ változásaira. Így azt mondhatjuk, hogy a hiperbolikus modellben $g$ paraméter mutatja a rövid távú türelmetlenség mértékét, $h$ pedig a hosszú távú türelemre utal. Lentebb láthatjuk majd, hogy milyen gyakorlati jelentőséggel bír ez a $t^{*}$ érték. A 3.1. táblázat néhány paraméterkombinációra mutatja azokat a $t *$ időket, amelyekre (1) teljesül. Az egyes sorokhoz tartoznak a kvázi-hiperbolikus függvény különböző $\delta$, az oszlopokhoz a különböző $\beta$ paraméterei Laibson (1996) alapján.

3.1a. táblázat. $t^{*}$ értéke $\delta_{\text {exp }}=0,952$

esetén (vagyis ha $r_{\exp }=0,05$ )

\begin{tabular}{|c|c|c|c|c|}
\hline 'hyp $\lceil\boldsymbol{\beta}$ & $\mathbf{0 , 2 5}$ & $\mathbf{0 , 5}$ & $\mathbf{0 , 7 5}$ & $\mathbf{0 , 8}$ \\
\hline $\mathbf{0 , 9 6}$ & 173,98 & 86,99 & 36,10 & 28,00 \\
\hline $\mathbf{0 , 9 7}$ & 75,63 & 37,81 & 15,69 & 12,17 \\
\hline $\mathbf{0 , 9 9}$ & 35,78 & 17,89 & 7,43 & 5,76 \\
\hline
\end{tabular}

Forrás: saját számítások 3.1b. táblázat. $t^{*}$ értéke $\delta_{\text {exp }}=0,909$

esetén (vagyis ha $r_{\exp }=0,1$ )

\begin{tabular}{|c|c|c|c|c|}
\hline hyp $1 \boldsymbol{\beta}$ & $\mathbf{0 , 2 5}$ & $\mathbf{0 , 5}$ & $\mathbf{0 , 7 5}$ & $\mathbf{0 , 8}$ \\
\hline $\mathbf{0 , 9 6}$ & 25,44 & 12,72 & 5,28 & 4,10 \\
\hline $\mathbf{0 , 9 7}$ & 21,38 & 10,69 & 4,44 & 3,44 \\
\hline $\mathbf{0 , 9 9}$ & 16,26 & 8,13 & 3,37 & 2,62 \\
\hline
\end{tabular}

A béta-delta diszkontálási modell legfőbb hátránya az exponenciálissal szemben, hogy folytonos esetre nem terjesztették ki, és bár a 3.2. ábrán nagyvonalúan folytonosként ábrázoltam, sőt a táblázatbeli értékek meghatározásánál is folytonosként kezeltem, a 0. és 1. periódus között még elvileg sem tisztázott, hogy hogyan lehetne folytonossá tenni.

A bankok által nyújtott kompenzáció lehet tehát túl alacsony, illetve túl magas is a döntéshozó által elvárthoz képest, az ő mentális diszkontálása során használt diszkontfüggvény paramétereitől függően. A magatartásgazdaságtan számos kísérletet végzett, melyekben éppen ilyen anomáliákra mutat rá (Thaler 1981, Ainslie 1992): két 
lehetőség közül a döntéshozónak az exponenciális modell szerint azt a lehetőséget kellett volna választania, hogy $x$ idő múlva szerez $A$ mennyiségü hasznot, ehhez képest ő azt választotta, hogy inkább $y$ idő múlva szerez $B$ mennyiségüt. Könnyen elképzelhető a helyzet, amikor ha a döntéshozónak aközött kell választania, hogy egy hónap múlva kapjon-e 20 dollárt, vagy két hónap múlva 30 dollárt a nagyobb, bár későbbi összeget választja, viszont ha azonnal kaphat 20 dollárt, vagy várhat egy hónapot a 30 dollárra, akkor inkább a korábbi, bár kisebb összeget. Az első esetben hajlandó egy hónapot várni a plussz 10 dollárra, de az azonnali jutalmazással elcsábítható (Lippai 2010, Thaler 1981), ez azonban az exponenciális diszkontálás mellett nem racionális. A harmadik alfejezetben azt mutatom be, hogy ugyanez a mentális diszkontálásbeli eltérés milyen nehézségeket okozhat több időszakon keresztül esedékes pénz, illetve hasznosságáramlások közötti választás, ilyen pénz-, illetve hasznosságáramok értékelése során.

\subsection{Nem-exponenciális diszkontálás a pénzáramok esetében}

A hiperbolikus diszkontálás irodalmának föárama az egyedi kifizetések jelenértékének meghatározásával foglalkozik. A kísérletek jó része arra irányul, hogy meghatározzák a diszkontálás paramétereit annak vizsgálatával, hogy a korábbi kisebb (sooner-smaller, SS, a fenti jelölésünk szerinti $x$ ) összeg mekkora későbbi nagyobb (later-larger, LL, korábbi jelölésünkben $X$ ) felel meg - ezek a matching-kísérletek -, illetve hogy egy adott korábbi kisebb és későbbi nagyobb közül melyiket választja az alany - ezek a choice-kísérletek.

Az optimális szabadalmak elméletében való, következő alfejezetben bemutatásra kerülő alkalmazás szempontjából viszont nem egyszeri kifizetések összehasonlítása, hanem pénzáramok értékelése a cél a nem-exponenciális modellek szerint. ${ }^{35}$ Hogyan határozza meg vajon a gazdasági szereplő a bizonyos időn keresztül, meghatározott időnként járó jövedelemáramlás (vagy bármilyen más „hasznosságáramlás”) jelenértékét? Az első alfejezetben arra mutattam rá, hogy amennyiben a gazdasági alanyok a jövőbeli eseményeket nem az exponenciális modell alapján számítolják le, hanem például a kvázihiperbolikus modell alapján, akkor az exponenciális modellel számított eredmény egyetlen időpillanat kivételével a jelenértéket vagy alul, vagy felülbecsli. Jelen szakaszban azt szándékozom bemutatni, hogy ez a hatás fokozottan torzítja az értékelést a pénzáramok

\footnotetext{
35 Bár az alábbiakban az egyszerüség és kezelhetőség kedvéért már csak a kvázi-hiperbolikus esettel foglalkozunk, a fentebb említett, a hiperbolikus modellel való minőségi egyezősége okán belátható, hogy a vizsgált probléma felvetésénél elegendő lesz ennek a modellnek a használata is. Minőségileg hasonló eredményre jutnánk a hiperbolikus modellek alkalmazásával is.
} 
jelenértékének becslése során, ami mindennemü olyan optimalizáció eredményét kérdésessé teheti, amely az exponenciális modellre épül.

A következőkben, végig a kvázi-hiperbolikus diszkontálási modellt alkalmazva, speciális pénzáramok jelenértékeit hasonlítom össze az adott pénzáramokra vonatkozó ismert exponenciális diszkontálást alkalmazó jelenértékekkel. Először az örökjáradék, mint kiindulás esetét vizsgálom meg, hogy onnan eljussak az optimális szabadalmak elméletének szempontjából nagyobb jelentőséggel bíró halasztott örökjáradékokhoz.

\section{Kvázi-hiperbolikus diszkontálás az örökjáradék esetében}

Kiindulásként vizsgáljuk meg, hogyan viszonyul egymáshoz egy $C$ összegű örökjáradék exponenciális, illetve kvázi-hiperbolikus módon diszkontált jelenértéke! Mivel

$$
P V_{p ; \exp }=\sum_{t=1}^{\infty} C \cdot \delta_{e}^{t}=\sum_{t=1}^{\infty} C \cdot \frac{1}{\left(1+r_{e}\right)^{t}}=C \cdot \frac{1}{r_{e}},
$$

illetve

$$
P V_{p ; h y p}=\sum_{t=1}^{\infty} C \cdot \beta \cdot \delta_{h}^{t}=\sum_{t=1}^{\infty} C \cdot \beta \cdot \frac{1}{\left(1+r_{h}\right)^{t}}=C \cdot \beta \cdot \frac{1}{r_{h}}
$$

ezért

$$
\frac{P V_{p ; h y p}}{P V_{p ; \exp }}=\beta \cdot \frac{r_{e}}{r_{h}} .
$$

Mivel a kvázi-hiperbolikus modell feltevése, hogy a hosszú távú kamatláb kisebb, mint az exponenciális kamatláb, és a béta egynél kisebb pozitív, ezért ez az arány egyaránt lehet egynél nagyobb vagy kisebb. Ha béta nagyobb (kisebb) a hosszú távú kamatlábak arányánál, akkor az eredmény egynél nagyobb (kisebb) lesz, vagyis a kvázi-hiperbolikus képlettel diszkontált örökjáradék értéke nagyobb (kisebb) lesz, mintha az exponenciális diszkontálást használtuk volna. Idézzük vissza az 3.2. ábrát! A fenti számításokkal a 3.2 ábrán látható két görbe alatti terület egymáshoz való viszonyát vizsgáljuk. ${ }^{36} \mathrm{Az}$ ábra alapján látható, hogy a két terület egyenlősége lehetséges, hiszen $t^{*}$ pontig a kvázihiperbolikus az exponenciális görbe alatt halad, utána pedig fölötte. Elképzelhető, hogy a béta-delta esetben amennyivel a $t^{*}$ pontig kisebb a görbe alatti terület, $t^{*}$ után pontosan annyival nagyobb, mint ahogyan az is, hogy kevesebbel vagy éppenséggel többel. A tényleges diszkontálási paraméterek határozzák meg, hogy melyik a valódi helyzet.

\footnotetext{
36 Görbe alatti területekről igazából akkor beszélhetnénk, ha folytonosnak vennénk a diszkontrátafüggvényeket. A diszkrét esetben valójában - ahogyan a számítás is mutatta - sorösszegekről van szó.
} 


\section{Kvázi-hiperbolikus diszkontálás halasztot örökjáradékok esetében}

Ennek a két területnek a $t$ szerint változó nagyságára építve meghatározható, hogy egy tetszőleges $T$ időpont esetében a $(T+1)$ időponttól a végtelenig tartó halasztott örökjáradék esetén milyen viszonyban van egymással a kvázi-hiperbolikus, illetve az exponenciális módon diszkontált jelenérték. Mivel a $t^{*}$ utáni időpontok kifizetéseit az exponenciális modell felülértékeli, így minél nagyobb $T$, annál nagyobb lesz a kvázihiperbolikus jelenérték az exponenciálishoz képest. A különböző módszerekkel diszkontált halasztott örökjáradék-jelenértékek viszonyát megadó kifejezés a

$$
\frac{P V_{T ; h y p}}{P V_{T ; \exp }}=\frac{\sum_{t=T+1}^{\infty} C \cdot \beta \cdot \frac{1}{\left(1+r_{h}\right)^{t}}}{\sum_{t=T+1}^{\infty} C \cdot \frac{1}{\left(1+r_{e}\right)^{t}}}=\frac{\frac{\beta}{r_{h} \cdot\left(1+r_{h}\right)^{T}}}{\frac{1}{r_{e} \cdot\left(1+r_{e}\right)^{T}}}=\beta \cdot \frac{r_{e}}{r_{h}} \cdot\left(\frac{1+r_{e}}{1+r_{h}}\right)^{T} .
$$

A zárójelben lévő kifejezés egynél nagyobb a kvázi-hiperbolikus diszkontáló nagyobb hosszú távú türelme miatt, ezért az utolsó tényező $T$-ben növekvő. Minél nagyobb tehát $T$ (minél későbbi időponttól kezdődő örökjáradékot vizsgálunk), annál nagyobb a kvázihiperbolikus módon számított jelenérték az exponenciálishoz viszonyítva. Mivel az első két tényező, mint fentebb láttuk, lehet egynél kisebb vagy nagyobb is, a tényleges arány szintén lehet egynél kisebb vagy nagyobb. Éppen eggyel lesz egyenlő, ha

$$
T=\frac{\ln \beta \cdot \frac{r_{e}}{r_{h}}}{\ln \frac{1+r_{h}}{1+r_{e}}}=\frac{\ln \left(\beta \cdot \frac{1-\delta_{e}}{1-\delta_{h}}\right)}{\ln \delta_{e}-\ln \delta_{h}}-1 .
$$

A 3.2. táblázat néhány kvázi-hiperbolikus béta- és deltaérték mellett mutatja $T$ értékeit, amelyekre (2) teljesül.

3.2a. táblázat. $T$ értéke $\delta_{\text {exp }}=0.952$

(azaz $\left.r_{\exp }=0,05\right)$ mellett

\begin{tabular}{|c|c|c|c|c|}
\hline hyp $1 \boldsymbol{\beta}$ & $\mathbf{0 , 2 5}$ & $\mathbf{0 , 5}$ & $\mathbf{0 , 7 5}$ & $\mathbf{0 , 8}$ \\
\hline $\mathbf{0 , 9 6}$ & 142,87 & 60,04 & 11,59 & 3,88 \\
\hline $\mathbf{0 , 9 7}$ & 47,92 & 10,91 & $-10,73$ & $-14,18$ \\
\hline $\mathbf{0 , 9 9}$ & $-5,66$ & $-23,37$ & $-33,73$ & $-35,38$ \\
\hline
\end{tabular}

3.2b. táblázat. $T$ értéke $\delta_{\text {exp }}=0.909$

( vagyis $r_{\text {exp }}=0,1$ ) mellett

\begin{tabular}{|c|c|c|c|c|}
\hline hyp $1 \boldsymbol{\beta}$ & $\mathbf{0 , 2 5}$ & $\mathbf{0 , 5}$ & $\mathbf{0 , 7 5}$ & $\mathbf{0 , 8}$ \\
\hline $\mathbf{0 , 9 6}$ & 9,34 & $-3,36$ & $-10,79$ & $-11,97$ \\
\hline $\mathbf{0 , 9 7}$ & 3,26 & $-7,41$ & $-13,66$ & $-14,65$ \\
\hline $\mathbf{0 , 9 9}$ & $-10,63$ & $-18,75$ & $-23,50$ & $-24,26$ \\
\hline
\end{tabular}

Forrás: saját számítások

A táblázatokban szereplő negatív számok azt jelentik, hogy a kvázi-hiperbolikus esetben a $t^{*}$ időponton túli jelenértékek összege annyival magasabb az exponenciális jelenértékeknél, 
hogy ezt nem tudja kiegyensúlyozni a $t^{*}$ előtti jelenértékek ellentétes irányú különbsége. Ebben az esetben a halasztott örökjáradékok kvázi-hiperbolikus módszerrel számolt jelenértéke mindig meg fogja haladni az exponenciálisan számított jelenértéket. A hosszú távú nagyobb türelem miatti távoli jövőbeli többlethaszon mindig nagyobb lesz, mint a rövid távú nagyobb türelmetlenség miatt a közelebbi jövőbeni alulkompenzáltság okozta veszteség. ${ }^{37}$

\subsection{A nem-exponenciális diszkontálás alkalmazása az optimális szabadalmak elméletében}

Az előző alfejezet tanulsága az, hogy az időtényező kezelése a diszkontálási modell megválasztásán keresztül befolyásolja bármilyen, dinamikus hatásokat is figyelembe venni igyekvő modell eredményeit. A korábbi fejezetben láthattuk, hogy a tudástermelés, az innováció éppen egy ilyen témakör: az optimális szabadalmi idő megállapításánál a mérleg egyik serpenyőjében időben később realizálódó dinamikus jóléti nyereségek jelenbeli értékét kell figyelembe venni.

A negyedik alfejezetben az innováció egy neoklasszikus mikroökonómiai modelljében szeretném alkalmazni a kvázi-hiperbolikus diszkontálást, alapozva az előző két fejezetben tett összehasonlításokra. A modell Duffy (2005) modellje, amely a szabadalmi védelem időtartama és az innováció nagysága közti összefüggést vizsgálja. Azt kívánom e modell segítségével megmutatni, hogy egyrészt elképzelhető olyan, gazdasági szempontból releváns helyzet, amikor indokolt lehet az exponenciális diszkontálás helyett más, például kvázi-hiperbolikus diszkontálási modell alkalmazása. Az innovációk esetén jelenbeli pénzberuházással jövőbeli pénzbeli többletnyereségen túl a fogyasztók által hosszú távon realizált jólétnövekményt érhetünk el, amelyek értékelésénél indokolt lehet a nem-exponenciális diszkontálási modellek használata. Hasonló természetủek lehetnek például a környezetvédelmi beruházások is. Másrészt rámutatok arra, hogy egy ilyen helyzetben a gazdaságpolitikai döntéshozók, és nem a fogyasztók vagy a vállalatok szempontjából lényeges az alkalmazott diszkontálási modell megfelelő megválasztása. Harmadrészt számszerüsítem a különböző modellválasztás eredményei közötti eltérést. Az első alfejezetben röviden bemutatom az innováció Duffy által használt alapmodelljét, a második alfejezetben felvetem a problémát és megindokolom a kvázi-hiperbolikus diszkontálás használatának szükségességét és mikéntjét, míg a harmadik alfejezet az eredményeket mutatja be.

\footnotetext{
${ }^{37}$ Ezen gondolatmenet és az örökjáradék-jelenértékek összehasonlítása mentén megmutatható, hogy ez általánosságban azokban az esetekben áll elö, amikor $\beta>\frac{r_{h y p}}{r_{\exp }}$.
} 


\subsubsection{Az alapmodell bemutatása}

Mint az előző fejezet bemutatta, a W. D. Nordhaustól kiinduló optimális szabadalmak elméletének alapgondolata, hogy mivel a technológiai tudás bizonyos közjószág-tulajdonságokkal bír, ezért az innovátor csak akkor lesz hajlandó új tudást előállítani, vagyis viselni az ezzel járó költségeket, hogyha az új tudás előállításából származó hasznokat is el tudja sajátítani. A szabadalom éppen egy olyan intézmény, ami ezt lehetővé teszi. ${ }^{38}$ A hosszabb időre szóló szabadalmi védelem az innovátor számára hosszabb időn keresztül biztosítja az innovációból származó profitok elsajátításának lehetőségét, és ezért nagyobb mértékű innovációra sarkall. A szabadalmi védelem miatt előálló monopol piaci pozíció átmeneti jóléti veszteséget okoz, a szabadalmi védelem lejáratakor viszont hosszú távon jóléti nyereség képződik, mikor mindenki szabadon hozzáférhet a találmányhoz. Míg az innovátor célja az innováicóból származó lehető legtöbb profit megszerzése, a gazdaságpolitika feladata a szabadalmi védelmi időtartam (a szabadalom élettartama) olyan megválasztása, hogy az, figyelembe véve az azonnali ideiglenes jóléti veszteséget és a későbbi hosszú távú jóléti nyereséget, maximális össztársadalmi jólétet biztosítson.

Az alternatív diszkontálási modell hatásainak bemutatásához John Fitzgerald Duffy (2005) modelljét fogom használni. Ez a modell már figyelembe vesz néhány olyan tényezőt, ami Nordhaus modelljében még nem szerepelt (versengés az innovációs piacon, innováció időzítése, elavulás), de kellően egyszerü, hogy könnyen szemléltethető legyen rajta a fó mondanivalóm.

Az alábbiakban nagy vonalakban vázolom Duffy modelljét az innováció és szabadalmi védelem összefüggéséről. Tekintsük egy közönséges jószág piacát! A piacon tökéletes verseny uralkodik, minden vállalat ugyanakkora, konstans határköltséggel tudja a termékét előállítani. A modellben vizsgált innováció folyamatinnováció, vagyis az innováció egyszerủen abból áll, hogy alacsonyabb költséggel való termelést tesz lehetővé az innovátor számára. Akárcsak a Nordhaus-modellben, az innováció itt is determinisztikus, vagyis az erőforrásráfordítás árán biztosan előáll az ismert hozamokat biztosító innováció.

A Duffy által felvetett innovációs modell három fontos ponton tér el a Nordhaus-által használttól. Először is feltételezi a termékpiacon az időben növekvő keresletet. Ez a

\footnotetext{
${ }^{38}$ Természetesen nem állítható, hogy szabadalmi védelem híján egyáltalán nem jönnének létre innovációk, hiszen az emberiség számos újítást bevezetett már a szabadalom intézményének létrejötte elött is (ami maga is egy társadalmi innováció volt!). Egy innováció hozadéka lehet például szakmai elismerés is, amely szintén motiválhatja a potenciális innovátort.
} 
növekvő kereslet időben növekvő bevételként jelenik meg az innovátor számára. A növekedés ütemét a gazdaság általános növekedésének ütemével azonosítja, és azzal a feltételezéssel él, hogy ez a növekedési ütem alatta marad az aktuális kamatlábnak. Másodszor, az egyes innovációk méretét adottnak és állandónak tekinti. Ezt azzal magyarázza, hogy az újítások egy-egy területen lépcsőzetesen történnek, és amint egy-egy újabb, kellően nagy lépést megtett egy innovátor, az innovációt máris szabadalmaztatja. Duffy modelljében tehát az innováció mindig ugyanakkora lépcsőkben történik, így a szabadalmi védelem hosszának változtatása végső soron nem a létrejövő innováció méretét (nagyobb költség árán nagyobb hozammal kecsegtető, vagy kisebb költségü, de kisebb hozamú lesz-e az innováció ${ }^{39}$ ), hanem az állandó nagyságú újítás létrejövetelének időpontját befolyásolja. A változó szabadalmi élettartalomra válaszul nem nagyobb vagy kisebb - azaz nagyobb, vagy kisebb költségcsökkentést eredményező - újítások jönnek létre, hanem a következő lépcsőfokot hamarabb vagy később lépik meg. A harmadik jellemzője a modellnek, hogy figyelembe veszi a versengést a kutatás-fejlesztés területén vagyis a már korábban említett szabadalmi versenyt -, ezért a profitmaximalizáló cégeknek mindaddig érdemes elörébb hozniuk az innováció időpontját, amíg még pozitív profitot érhetnek el. Nordhaus modelljében egyetlen cég foglalkozott innovációval, így az adott szabadalmi élettartam mellett ez az egyetlen cég a profitmaximumban elérhetett akár pozitív profitot is. A kutatás-fejlesztést végző cégek közötti verseny azonban ebben a modellben ezt a profitlehetöséget eltünteti. ${ }^{40}$

A modell szerint az innováció jóléti hozadéka elméletileg három részből állhat: egyrészt $H$ nagyságú járadékot biztosít a feltalálónak a szabadalmi élettartam alatt. Másrészt, ha a feltaláló nem tudja járadékként elsajátítani a teljes jóléti hozadékot, akkor abból $J$ nagyságú hozam csordulhat túl további külső szereplőknek extern haszonként, illetve egy $K$ része pedig a monopol-hatalom megszünését követően fogyasztói többletté alakuló korábbi holtteher-veszteség. A feltevések szerint $H_{0}, J_{0}$ és $K_{0} \geq 0$, és időben az innováció iránti kereslettel azonos $g$ ütemben növekvők, vagyis $H(t)=H_{0} \cdot e^{g t}$, $J(t)=J_{0} \cdot e^{g t}$, és $K(t)=K_{0} \cdot e^{g t}$. Az innováció $I$ költsége konstans és független az innováció időpontjától.

\footnotetext{
${ }^{39}$ A Nordhaus modellben a kutatás-fejlesztésre fordított erőforrás és az innováció mérete, fontossága közti összefüggésről korábban a 2.1. fejezetben írtam.

${ }^{40}$ Az kutatás-fejlesztési ráfordítások és az innováció „időzítése”, illetve a verseny a potenciális innovátorok között a kutatásban már korábban is megjelent kiterjesztések, lásd Loury (1979).
} 
A modell szerint tehát az innovátornak az adott $L$ szabadalmi élettartam mellett addig érdemes előbbre hozni az innováció időpontját $\left(t_{I}\right)$, amíg még pozitív profit realizálható. A szabadalmi verseny eltünteti a profitot, így az optimumban a

$$
\pi\left(t_{I}\right)=\int_{t_{I}}^{t_{I}+L} H_{0} \cdot e^{-(r-g) t} d t-I \cdot e^{-r t_{I}}=0
$$

feltétel adódik. A feltétel első tagja az innovációtól a szabadalmi élettartam lejártáig az innovátor által elsajátítható bevételek jelenre diszkontált értéke, míg a második tag az újítás megszületésekor vállalandó költség jelenértéke. A modell az exponenciális diszkontálás folytonos változatát alkalmazza, ahol az alkalmazott diszkontfaktor $\delta^{t}=e^{-r_{e} t}$. A (3) egyenletet $t_{I}$-re rendezve az innováció időpontjára az alábbi összefüggés adódik: ${ }^{41}$

$$
t_{I}=\frac{1}{g} \ln \left[\frac{I \cdot(r-g)}{H_{0} \cdot\left(1-e^{-(r-g) \cdot L}\right)}\right]
$$

Az optimális innovációs időpontról belátható, hogy $\partial t_{I} / \partial L<0$, vagyis hogy a hosszabb szabadalmi élettartam korábbra hozza az innováció időpontját. A (4) egyenlet tehát az exogén változók nagyságának függvényében megmutatja, hogy a szabadalmi versenyben a vállalatnak különböző $L$ szabadalmi élettartamokhoz milyen $t_{I}$ időpontig érdemes elöre hoznia az innováció megvalósítását.

A modellben $L$ növelése az innováció időpontját $\left(t_{I}\right)$ egyértelműen korábbra hozza, a szabadalom lejáratának időpontját $\left(t_{E}=t_{I}+L\right)$ viszont nem növeli feltétlenül. Ezt mutatja az alábbi 3.3. ábra.

3.3. ábra. A minimális optimális szabadalmi idő és az optimális szabadalmi idő

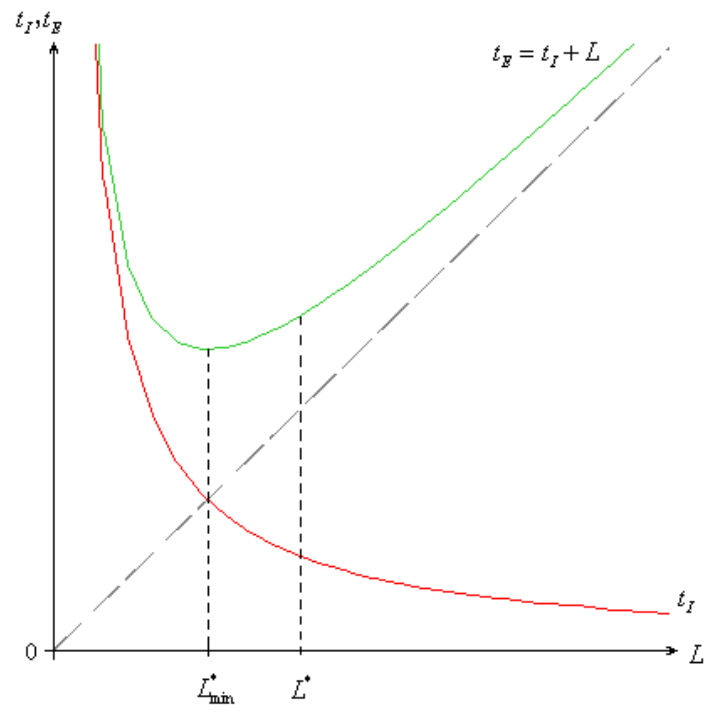

Forrás: Duffy $(2005,3$. o.)

\footnotetext{
${ }^{41}$ A fejezet levezetéseit az 1. számú melléklet tartalmazza.
} 
Az ábrán a $t_{I}$ az innováció vállalat által választott időpontját mutatja a szabadalmi élettartam függvényében (4)-nek megfelelően. A Nordhaus-modell feltételei szerint ez egybeesne az $L$ tengellyel. A $t_{E}$ függvény a szabadalom lejáratának idejét mutatja a szabadalmi élettartam függvényében. A Nordhaus-modell szerint ez az ábrán látható $45^{\circ}$ ban emelkedő függvény lenne, de Duffy modelljében ez egy eleinte csökkenő, majd növekvő függvény.

Amíg a szabadalmi védelem hosszának növelése korábbra hozza a szabadalom lejáratának időpontját is, addig feltétlenül érdemes növelni $L$-et (az ábrán $L_{\min }^{*}$ jelöli, és Duffy minimális optimális szabadalmi időnek nevezi). A fentebb említett átváltás az ideiglenes jóléti veszteségek és a hosszú távú jóléti nyereségek között csak ennél nagyobb $L$ esetében jelenik meg, és akkor is csak abban az esetben, ha az innováció már a szabadalmi védelem időszaka alatt is szerez többlethasznokat $(J)$ a társadalomnak. Az $L$ növeléséből származó hosszú távon bekövetkező jóléti nyereség, hogy a hamarabb bekövetkező innováció miatt a társadalom korábbi időponttól kezdve jut hozzá a $J$ haszonhoz. Az azonnali jóléti veszteség pedig, hogy a később megszünő monopolhatalom miatt csak későbbi időponttól kezdve jutnak hozzá a $H+K$ többlethasznokhoz. Addig érdemes növelni $L$-et tehát, amíg a növelés hasznainak diszkontált értéke meg nem egyezik a növelés költségeinek diszkontált értékével.

Ezt az ábrán $L^{*}$-gal jelölt optimális szabadalmi védelmi hosszúságot ki lehet számítani az innovációból származó összes társadalmi jólét maximalizálásával, figyelembe véve a vállalatok viselkedését. Az innovációból származó összes társadalmi jólét jelenértéke

$$
W_{e}(L)=\int_{t_{I}}^{t_{I}+L} J_{0} \cdot e^{-\left(r_{e}-g\right) t} d t+\int_{t_{I}+L}^{\infty}\left(J_{0}+H_{0}+K_{0}\right) \cdot e^{-\left(r_{e}-g\right) t} d t
$$

ahol az első tag a szabadalom élettartama alatti hozamok jelenértékét adja meg, a második tag a szabadalom lejártával szerezhető jóléti hozamok jelenértékét mutatja. A társadalmi jóléthez még hozzátartozik az innovátor által elért összes jólét, de mivel a (3) feltételböl tudjuk, hogy az innovátor által elsajátított járadékok jelenértékének és az innovációs költség jelenértékének különbsége 0, így ezeket a tagokat kihagyva kaptuk a fenti egyszerübb függvényt. A gazdaságpolitikai döntéshozónak tehát úgy kell meghatároznia $L$ értékét, hogy az innovációból származó társadalmi jólét maximális legyen. A feltételt felhasználva megoldva a $\partial W(L) / \partial L=0$ egyenletet a következő összefüggés adódik: ${ }^{42}$

$$
\frac{J_{0}}{H_{0}+K_{0}}=\frac{g-r_{e} \cdot B}{r_{e}-g}
$$

ahol $B=e^{-(r-g) \cdot L}$.

\footnotetext{
${ }^{42}$ A vonatkozó levezetést az 1. melléklet 2. pontja tartalmazza.
} 
Az egyenlet egyetlen változója $L$, amire megoldható, és megkapjuk belőle az $L^{*}$ optimális szabadalmi élettartamot. A 3.3. ábra tanúsága szerint ez az optimális szabadalmi idő nagyobb, mint $L_{\min }^{*}$. A modellben csak akkor érdemes a szabadalmi védelmi időt úgy meghatározni, hogy ennél a minimálisan optimális időnél hosszabb legyen, vagyis hogy a szabadalom végül is ne a lehető leghamarabb járjon le, ha már a szabadalmi védelmi idő alatt származnak külső szereplőknek is hasznai a találmányból, vagyis ha $J>0$.

\subsubsection{A kvázi-hiperbolikus diszkontálás beillesztése a modellbe}

Jelen alfejezetben beillesztem a hiperbolikus diszkontálást Duffy fentebb bemutatott modelljébe és bemutatom, miért lehetséges és indokolt ez a módosítás.

Az innováció által a társadalom számára generált jólétet két, minőségileg különböző részre bonthatjuk fel. Az egyik rész az innovátor vállalat számára generált, pénzben mérhető jólétnövekmény (profit), a másik pedig a fogyasztók által a (közelebbi vagy távolabbi) jövőben realizálandó, pénzben nem mérhető fogyasztóitöbblet-növekmény.

Mi oka lenne egy vállalatnak arra, hogy ne exponenciálisan diszkontálja a jövőt? Az exponenciális diszkontálási modell egyik nagy sikere abban rejlik, hogy a bankok ezt a fajta diszkontálást alkalmazzák, mikor kamatot fizetnek vagy kamatot szednek. A gazdasági realitások talaján álló vállalatoknak is így kell tehát számolniuk, amikor jövőbeli fizetési kötelezettségeiket vagy éppen elmaradt hasznaikat veszik számításba. Az exponenciális kamatlábat kellene alkalmazniuk akkor is, amikor a megszerzett profitokat a bankban elhelyezik, illetve akkor is, amikor a jövőbeli profitjuk terhére hitelt szeretnének felvenni.

A fogyasztók azonban, a magatartás-gazdaságtani kísérletek tanúsága szerint mentálisan máshogyan diszkontálják a jövőbeni hasznosságokat. Választásaik még akkor sem teljesen összeegyeztethetők az exponenciális modell előrejelzéseivel, ha tényleges jövőbeli pénzhozamok között kell dönteniük. A jövőbeli fogyasztóitöbblet-növekmény azonban ennél jóval absztraktabb, például abból a szempontból, hogy a jelenlegi fogyasztói többletet nem lehet bankba tenni és kamatoztatni, hasonlóképpen a jövőbeli fogyasztói többlet terhére sem lehet hitelt felvenni.

A nem-exponenciális diszkontálásnak a modellbe való beillesztésénél három dologra kell figyelemmel lenni. Elöször is, a nem-exponenciális diszkontálást csak olyankor használom, ha fogyasztókra vonatkozó jövőbeli hasznosságok értékeléséről van szó a modellben. Ahol azonban ténylegesen pénzben kifejezhető, a vállalat számára megjelenő 
jövőbeli bevételekről, illetve költségekről van szó, ott megtartom az eredeti exponenciális modellt.

Másodsorban, annak ellenére, hogy, mint ahogyan fentebb is jeleztem, a kvázihiperbolikus diszkontálás diszkrét, és folytonos módon nem értelmezhető, jelen tanulmányban mégis egy folytonos közelítéssel fogok élni, az exponenciális modell mintájára, vagyis a kvázi-hiperbolikus diszkontfaktort $\beta \cdot \delta_{h}^{t}=\beta \cdot e^{-r_{h} t}$ formában használom. Azért döntöttem a kvázi-hiperbolikus modell folytonossá tétele mellett, hogy az eredmények jobban összehasonlíthatóak legyenek: az optimális szabadalmak elméletében a diszkontálást mindig folytonos módon végzik el. A kvázi-hiperbolikus modell esetében azért hangoztatják, hogy nem értelmezhető folytonos változatban, mert a 0. és 1. időszak közötti erőteljes diszkontálás okán nem lehet a diszkontfüggvényt folytonossá tenni. Az első időszaktól kezdődően azonban a kvázi-hiperbolikus diszkontálás ugyanúgy működik, mint az exponenciális. Az ebből származó problémát kétféle képpen lehetne áthidalni: egyrészt értelmezhetnénk úgy a rövid távú türelmetlenséget, hogy a döntéshozó minden olyan jövőbeli hozamot azonnal $\beta$ mértékben leértékel, ami csak egy kicsivel is későbbi időpontban van: a diszkontfüggvény a $\mathrm{t}=0$ időpontban nem 1 , hanem $\beta$ értéket vesz föl. A másik megoldási lehetőség arra épül, hogy az első időszak után a kvázihiperbolikus modell ugyanúgy müködik, mint az exponenciális. Azok a tényezők ugyanis, melyek a kvázi-hiperbolikus módszerrel diszkontálandók, mind az innováció időpontja után jelentkeznek. Az említett probléma tehát csak akkor bír jelentőséggel, ha az innováció időpontja az 1. időszaknál hamarabbra esik. (4) átalakításával látható, hogy ez abban az esetben következhet be, ha

$$
L>\frac{1}{r_{e}-g} \cdot \ln \frac{e^{g}}{e^{g}-\frac{I}{H_{0}}\left(r_{e}-g\right)}
$$

Ellenőrizhető azonban, hogy a paraméterek Duffy által használt értékei mellett mind $L_{\min }^{*}$, mind pedig $L^{*}$ értékei kisebbek ennél. ${ }^{43}$

Harmadsorban pedig, mivel a döntéshozók nem maguk a fogyasztók, hanem az ö jólétüket figyelembe vevő állam, ezért a nem-exponenciális diszkontálásból adódó időbeli inkonzisztencia nem játszik szerepet a döntéshozásban. A preferenciafordulás következménye itt éppenséggel a „siettetés” - mint a halogatás ellentéte - lenne: a korábban meghatározott szabadalmi védelmi időt a fogyasztók később szeretnék

\footnotetext{
${ }^{43}$ A levezetés megtalálható az 1 . melléklet 3. pontja alatt.
} 
folyamatosan csökkenteni, a lejáratot fokozatosan elörébb hozva. Az állam azonban ebben a modellben a 0 . időpontban elkötelezi magát egy szabadalmi élettartam mellett, amit ezután az idő múlásával nem változtat meg.

A vállalatok számára továbbra is adottságként jelenik meg az állam által meghatározott $L$ értéke, és ezen adottság mellett határozzák meg az innováció optimális időpontját a nullprofit-feltevés mellett, továbbra is az exponenciális diszkontálást alkalmazva. Az állam számára ebből következő feltétel tehát továbbra is változatlanul (4).

Az állam a maximális jólét elérésére törekszik, miközben a vállalatok optimalizáló viselkedését is figyelembe kell vennie. A maximalizálandó jólét a kvázi-hiperbolikus diszkontálást használva a megfelelő (a fogyasztókra vonatkozó) tagok esetén:

$$
W_{h}(L)=\int_{t_{I}}^{t_{l}+L} J_{0} \cdot \beta \cdot e^{-\left(r_{h}-g\right) t} d t+\int_{t_{I}+L}^{\infty}\left(J_{0}+H_{0}+K_{0}\right) \cdot \beta \cdot e^{-\left(r_{h}-g\right) t} d t .
$$

Felhasználva a 2. alfejezet tanulságait a különböző diszkontálási modellekkel számított halasztott örökjáradék-jelenértékekkel kapcsolatban következtethetünk arra, hogy hogyan viszonyul egymáshoz $W_{e}(L)$ és $W_{h}(L)$. Az 1. és 2. alfejezet eredményei alapján az a feltételezésem, hogy egyrészt minden egyéb változatlansága mellett azonos $t_{I}$ függvény esetén más $L$ érték fogja maximalizálni a $W_{e}(L)$ jólétet, mint a $W_{h}(L)$ jólétet. Másrészt, hogy a $W_{e}(L)$ jólétet maximalizáló $L$ attól függően lesz nagyobb vagy kisebb, mint a $W_{h}(L)$ jólétet maximalizáló $L$, hogy az eredeti optimális szabadalmi élettartam hosszabb vagy rövidebb, mint a (2) képlettel kiszámított $T$.

\subsubsection{Eredmények}

Megoldva a $\partial W_{h}(L) / \partial L=0$ egyenletet a feltétel felhasználásával, egy, az eredetihez hasonló kifejezést kapunk: ${ }^{44}$

$$
\frac{J_{0}}{H_{0}+K_{0}}=\frac{g-r_{e} \cdot B}{r_{e}-g} \cdot \frac{B_{h}}{B},
$$

melyben ismét $B=e^{-\left(r_{e}-g\right) \cdot L}$ és $B_{h}=e^{-\left(r_{h}-g\right) \cdot L}$. A megoldás érdekessége, hogy az exponenciális diszkontáláshoz képest értelmezett nagyobb rövid távú türelmetlenségre utaló $\beta$ paraméter eltünt, a továbbiakban nem játszik szerepet.

Az egyenletböl először is azonnal adódik, hogy ha a kvázi-hiperbolikus diszkontálás paramétereit úgy választjuk meg, hogy $\beta=1$ és $r_{h}=r_{e}$, akkor az eredeti exponenciális diszkontálást kapjuk vissza, a fenti képletben a jobb oldalon szereplő második tört értéke

\footnotetext{
${ }^{44}$ A levezetéshez lásd az 1. melléklet 4. pontját.
} 
egy. Így ugyanaz az eredmény adódik az optimális szabadalmi élettartamra. Jelölje $L^{* *}$ a szabadalmi védelmi időnek azt a hosszát, amely kielégíti az egyenletet abban az esetben, ha $\beta<1$ és $r_{h}<r_{e}$ ! Zárt formulával ebben az esetben ugyan nem adható meg az optimális szabadalmi élettartam, de megvizsgálhatjuk $L^{*}$ és $L^{* *}$ viszonyát. ${ }^{45}$ (6) és (8) összevetésével adódik, hogy

$$
\frac{g-r_{e} \cdot B^{*}}{r_{e}-g}=\frac{J_{0}}{H_{0}+K_{0}}=\frac{g-r_{e} \cdot B^{* *}}{r_{e}-g} \cdot \frac{B_{h}^{* *}}{B^{* *}},
$$

ahonnan

$$
L^{*}>L^{* *} \text {. }
$$

Ha az optimális szabadalmi idő meghatározásánál figyelembe akarjuk venni, hogy a fogyasztók a jövőbeli hasznokat nem exponenciális módon diszkontálják, akkor ceteris paribus egy rövidebb szabadalmi élettartamot kell meghatározni, mintha exponenciális diszkontálást tételeznénk fel róluk. $W_{h}(L)$ jólétet más $L$ maximalizálja, mint a $W_{e}(L)$ jólétet. A kétféle módon számított optimális szabadalmi élettartam azonban mindig ugyanabba az irányba tér el egymástól. Azt kapjuk, hogy a kvázi-hiperbolikus egyenletet igazzá tevő $L^{* *}$ biztosan kisebb, mint az exponenciális egyenletet igazzá tevő $L^{*}$. A kétféle modellel kalkulált optimális szabadalmi élettartam egymáshoz való viszonya a kiinduló feltételezésemmel ellentétben nem függ a 3.2. fejezet (2) képletében kiszámított $T$-től.

A jelenség magyarázata a kvázi-hiperbolikus diszkontálás időben növekvő türelmességében rejlik. $L$ növelése $L_{\text {min }}^{*}$ fölé korábbra hozza az innováció idejét, míg távolabbra tolja a szabadalom lejártának idejét. Visszatekintve a 3.2. ábrára az $L^{*}$ értékét úgy kaptuk meg $L_{\min }^{*}$-hez képest, hogy addig növeltük a szabadalmi védelem időtartamát, amíg a növelésböl származó költségek jelenértéke meg nem egyezett a növelésből származó hasznok jelenértékével. A kvázi-hiperbolikus esetben azonban ezeket az időben később jelentkező költségeket a hosszú távú nagyobb türelem miatt gyengébben, míg az időben közelebb jelentkező hasznokat a rövid távú nagyobb türelmetlenség miatt erősebben diszkontáljuk, mint az exponenciális esetben. Ezért tehát az $L$ növeléséből származó hasznok és költségek jelenértéke csak egy $L^{*}$-nál kisebb $L^{* *}$ esetén lehet egyenlö.

\footnotetext{
${ }^{45}$ A levezetés megtalálható az 1. melléklet 5. pontjában.
} 
Az alábbi, 3.4. ábra az optimális szabadalmi időt mutatja az exponenciális, illetve a kvázi-hiperbolikus diszkontálást alkalmazva. Az ábrán $\frac{J_{0}}{H_{0}+K_{0}}$ különböző értékeihez rendeltem hozzá $L^{*}$ (piros folytonos vonallal) illetve $L^{* *}$ (zöld folytonos vonallal) értékeit, miközben rögzítettem a növekedési ütem, illetve a diszkontálási paraméterek értékeit $g=0,02, r_{e}=0,085$ és $r_{h}=0,045$ értéken.

A kétféle optimális szabadalmi élettartam közti eltérés minőségi, tehát nem csupán az alkalmazott kamatláb megváltozása okozza. A kvázi-hiperbolikus esetet, mint általános esetet véve, ha a (8) egyenletben $r_{h}$-t közelítjük $r_{e}$-hez, akkor közelítünk az exponenciális modell eredményéhez, és ha $r_{h}=r_{e}$, akkor $L^{*}=L^{* *}$. Ha viszont az exponenciális modellből adódó (6) képletben változtatjuk meg egyszerüen $r_{e}$-t, és közelítjük $r_{h}$-hoz, akkor az exponenciális módon számított optimális szabadalmi idő bármekkora társadalmi többlethányad mellett el fog térni a kvázi-hiperbolikusan számítottól: $L^{*}>L^{* *}$ (ezt a fajta változtatást mutatja a 3.4. ábra szaggatott piros vonala).

3.4. ábra. Az optimális szabadalmi élettartam hossza exponenciális, illetve kvázihiperbolikus diszkontálás mellett

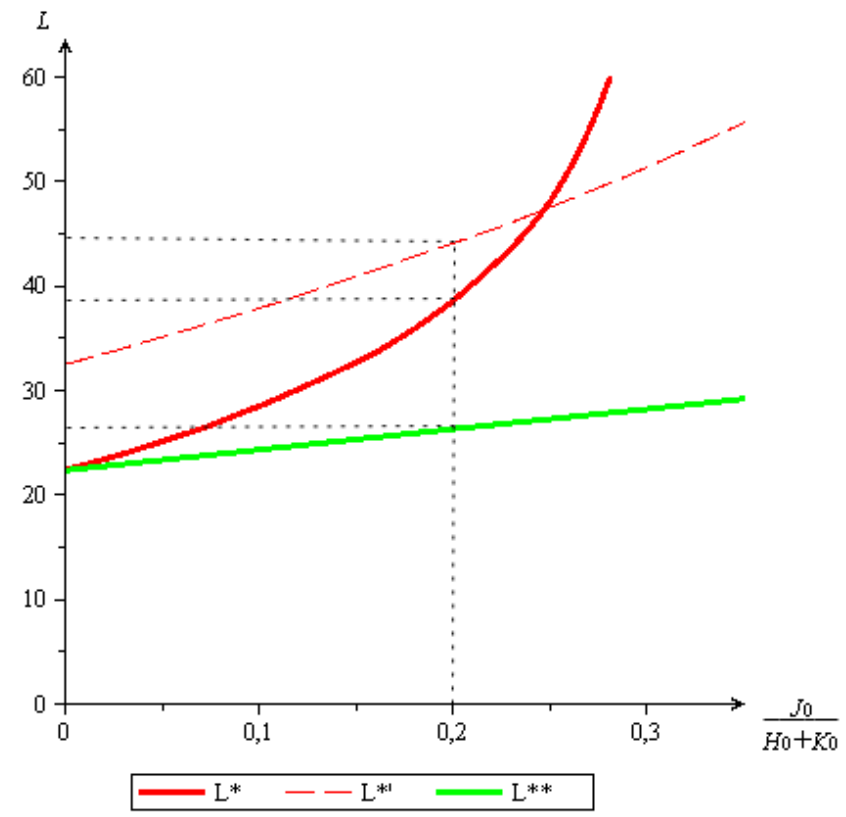

Forrás: saját szerkesztés

A 3.4. ábrán $L^{*}$ és $L^{* *}$ azonos tengelymetszettel indul: ez a már föntebb említett minimálisan optimális szabadalmi idő. Ennek nagyságát a szabadalom legkorábbi lejárata határozza meg, csak az innováció időpontjától és a szabadalmi védelem hosszától függ. 
Mivel az innováció időpontját a vállalatok döntik el, az ő viselkedésüket leíró feltételben pedig nem változtattam meg a diszkontálási modellt (ők ugyanis valós, pénzben mérhető bevételeket és költségeket vetnek össze egymással), ezért egyezik meg mindkét modell esetében ez a minimálisan optimális szabadalmi idő. Ha az exponenciális diszkontálás kamatlábát csökkentenénk, maga a minimálisan optimális szabadalmi idő is följebb tolódna: ezt mutatja az ábrán piros szaggatott vonallal jelölt $L^{*}$,

Az optimális szabadalmi idő meghatározásánál döntő tényező $\frac{J_{0}}{H_{0}+K_{0}}$, a Duffy által társadalmi többlet-hányadnak (Social surplus ratio, Duffy 2005, 13. o.) nevezett mutató. Ez az innovációból a társadalom által elsajátítható túlcsorduló hasznokkal van kapcsolatban. Az innováció időszakonként $J(t)$ többlethasznot hoz az innováció időpontjától kezdődően, és további $H(t)+K(t)$ többlethasznot a szabadalom lejártától kezdve: e kettő aránya a társadalmi többlet-hányad. Ez a mutató nulla értéket vesz föl, ha $J_{0}=0$, vagyis hogyha a találmányból extern hasznok nem származnak: az újítás a szabadalmi védelem időszaka alatt csak az innovátornál eredményez bevételeket. Ekkor az innováció összes előnye a fogyasztók számára csak a szabadalom lejárta után jelentkezik. Ennek az összes előnynek a jelenértéke pedig mind az exponenciális, mind a kvázi-hiperbolikus diszkontálást használva a fent említett $L_{\text {min }}^{*}$ minimálisan optimális szabadalmi idő esetében lesz maximális. Ez indokolja, hogy a 3.4. ábrán mindkét függvény függőleges tengelymetszete éppen a Duffy $\left(2005,12\right.$. o.) által meghatározott $L_{\text {min }}^{*}=\frac{1}{r-g} \cdot \ln \left(\frac{r}{g}\right)$, a paraméterek általam rögzített értékei mellett 22,26 év. A társadalmi többlet-hányad növekedése azt jelenti, hogy egyre nagyobb a szabadalom élettartama alatt megszerezhető hasznok nagysága a szabadalom lejárta után szerezhető többlethasznokhoz képest, vagyis annál érdemesebb siettetni az innovációt. Ennek megfelelően az ábrán a társadalmi többlethányad növekedése mind az exponenciális, mind a kvázi-hiperbolikus diszkontálás esetén növeli az optimális szabadalmi élettartamot. A társadalmi többlet-hányadról Duffy azt írja (13. o.), hogy az általa használt modellben, ahol úgynevezett „,run-of-the-mill” folyamatinnovációkat vizsgál, ennek a nagysága általában nullához közeli. Az ilyen innovációk esetében egy már létező technológián hajtanak végre valamilyen kis lépésnyi fejlesztést, és a hatékonyabb technológia verseng a már meglévővel. A kvázi-hiperbolikus modell bevezetése és a rá jellemző alacsonyabb hosszú távú kamatláb alkalmazása ceteris paribus csökkenti az optimális szabadalmi élettartamot, az exponenciális modell alkalmazásával 
kapott optimális élettartamhoz képest. Megmutatható ugyanakkor, hogy az exponenciális modellnél maradva, és abban csökkentve a kamatlábat, az optimális szabadalmi idő növekedne. A különbség tehát minőségi, nem csupán az alkalmazott alacsonyabb kamatláb okozza. A 3.4. ábrán bejelöltem a társadalmi többlet-hányad egy tetszőleges értékét, ezen értéknél a két függvényérték közti különbség mutatja meg, hogy mennyivel tér el egymástól $L^{*}$ és $L^{* *}$. Ahogyan a számítások is igazolták, tetszőleges pozitív társadalmi többlet-hányad esetén fennáll, hogy $L^{*}>L^{* * *}$.

Duffy tanulmányában (13. o.) több indokot is felsorol, amely miatt mégis érdemes a szabadalom élettartamát a minimálisan optimális szabadalmi élettartamban meghatározni a ténylegesen optimális mellett. Az egyik indoka éppen az említett társadalmi többlet-hányad nehéz meghatározása, főleg amennyiben ezt egy „átlagos” innovációra kell meghatározni. Másik érve, hogy megmutatható a modellből, hogy $L_{\min }^{*}$ esetén az elérhető társadalmi jólét legalább $70 \%$-a az $L^{*}$ esetén, tehát elvileg maximálisan elérhető társadalmi jólétnek. Ha a kvázi-hiperbolikus diszkontálást alkalmazó modell optimális szabadalmi élettartama $L^{* *}<L^{*}$, akkor ez az arány vélhetően még kedvezőbb. Ha a kvázi-hiperbolikus diszkontálási modellt pozitív és nem normatív modellként alkalmazzuk, akkor a jelen modell tanulsága az optimális szabadalmak Duffy-féle modelljére nézve az, hogy a minimálisan optimális szabadalmi élettartamot alkalmazva a tényleges társadalmi jólét maximumától kevesebbel térünk el, mint azt az exponenciális modell alkalmazása sugallná.

A dolgozatom 3. fejezetében az optimális szabadalmak esetének egy gazdaságpszichológiai kiterjesztését vizsgáltam meg. A célom egy a gazdaságpszichológia által felvetett jelenség: az időben növekvő fogyasztói türelem és az ezt modellező nemexponenciális diszkontálás integrálása az optimális szabadalmak elméletébe. Amennyiben a háztartások valójában hosszabb távon nagyobb türelemmel bírnak, mint amilyennel az exponenciális diszkontálási modell szerint bírniuk kellene, akkor ez a hosszabb távú nagyobb türelem más időtávon fogja létrehozni az egyensúlyt a szabadalmi védelem által okozott ideiglenes veszteségek és a hosszú távon realizálódó jóléti nyereségek között. Az általam felépített modell egy minőségi különbséget mutat az exponenciális diszkontálással számított optimális szabadalmi élettartam és a kvázi-hiperbolikus diszkontálással számított optimális szabadalmi élettartam közt. Ez a minőségi különbség annyit tesz, hogy a kétféle optimális élettartam közti különbség nagysága, de még csak iránya sem indokolható 
pusztán azzal, hogy alacsonyabb kamatlábat alkalmaztunk az optimális élettartam meghatározásánál. Ez annak ellenére igaz, hogy a kvázi-hiperbolikus diszkontálóknak az exponenciális diszkontálókhoz viszonyított rövid távon érvényesülő nagyobb türelmetlenségét jelző $\beta$ végül explicit módon nem is jelenik meg az optimális szabadalmi élettartamot meghatározó összefüggésben.

Az eredmény értelmezése abban rejlik, hogy egy kvázi-hiperbolikusan diszkontáló fogyasztó a jövőben később realizálódó hasznokat kisebb mértékben diszkontálja, mint egy exponenciálisan diszkontáló fogyasztó, ezért az exponenciális modell a közeli jövőbeli hasznokat felül, míg a távoli jövőbeli hasznokat alulértékeli. A szabadalmi védelem élettartamának csökkentése az innováció időpontját későbbre, míg a szabadalom lejártának idejét korábbra hozza a modell szerint. Ha a későbbi innováció miatti közeljövőbeli veszteségeket erősebben, a korábbi lejárat miatti későbbi jövőbeli nyereségeket viszont kisebb mértékben diszkontáljuk, mint az exponenciális esetben, akkor társadalmi szinten jólétnövelö a szabadalmi élettartam csökkentése.

Az alkalmazott modellben az innováció időpontja időben változó, viszont az innovatív lépcső (az innovációra fordított erőforrások és a velük elérhető eredmény) rögzített nagyságú. Érdemes lenne megvizsgálni, hogy az itt megfigyelt eredményeknek megfelelően változna-e az optimális szabadalmi hossz egy rögzített innovációs időpontot de változtatható nagyságú innovatív lépcsőt alkalmazó modell esetében is (mint amilyen például az eredeti Nordhaus-modell volt). További érdekes kutatási irány lenne az előző fejezetben bemutatott, az optimális szabadalmi időt befolyásoló tényezőket is figyelembe vevő modellekbe beépíteni a hiperbolikus diszkontálást.

Disszertációmban eddig a szabadalmi védelem egyik célját emeltem ki: az innovátorok ösztönzését az új technológiai tudás előállítására és alkalmazásba vételére. Az optimális szabadalmak elméletének keretében a szabadalmi védelem hosszának meghatározásával befolyásolni lehet az innováció előállításának és a szabadalmi védelem lejártának időpontját úgy, hogy a lehető legnagyobb társadalmi jólét áljon elő.

A szabadalmi védelem intézményének egy másik célja azonban az innovációk terjedésének elősegítése. A mi országunkban érvényes szabadalmi védelem nem ösztönzi az országhatáranikon kívüli innovátorokat arra, hogy technológiai újításokat találjanak fel és vegyenek alkalmazásba. Abban viszont fontos szerepük lehet, hogy ha már ők azokat külföldön valamilyen ösztönzésre előállították, akkor a nálunk érvényes szabadalmi 
szabályozás ezeket az innovátorokat rávegye, hogy újításaiknak a mi országunkba is behozzák, hogy azok nálunk is elterjedhessenek.

Az utolsó két fejezetében a szabadalmi védelem intézményének a tudás termelésére gyakorolt hatásainak vizsgálatáról áttérek annak tudásterjedésben betöltött szerepének vizsgálatára. A negyedik fejezetben kilépek a zárt gazdaságból, az innovátornak így lehetősége nyílik az általa feltalált újítás költségelőnyeit nem csupán a belföldi piacon, hanem egy attól elkülönült külpiacon is érvényesíteni. Mivel azonban a hazai és a külföldi piacokon nem biztos, hogy ugyanazok a játékszabályok érvényesülnek, ami a szabadalmi védelem intézményét illeti, a profitmaximalizáló vállalatnak ezen két, piaconként potenciálisan eltérő feltételrendszer mentén kell optimalizálnia akár az innovációra fordítandó erőforrásokat, akár azt, hogy megjelenjen-e egyáltalán a külpiacon, ha igen, hogyan, és mekkora részt hasítson ki magának a külföldi keresletből.

E rendkívül szerteágazó problémakört erősen leszükítve vizsgálom a következő fejezetekben. Az ötödik fejezetben még mindig a vállalati optimalizáció szintjén vizsgálódom, itt azonban már az innovációra fordított erőforrásokat, a $\mathrm{K}+\mathrm{F}$ kiadásokat adottnak veszem, és csak a külpiacon való megjelenési döntésre koncentrálok. A lehetséges külpiaci megjelenési formákon belül is vizsgálatom tárgya a termékexport: megvizsgálom, hogy az eltérő nemzeti szabadalmi intézményrendszer figyelembevételével hogyan dönt a hazai innovátor arról, hogy megjelenjen-e a külföldi piacon, és hogy milyen termékválasztékkal tegye azt.

A feltételezésem az, hogy a hazai innovátor annak függvényében határoz a külföldi piacra lépésről, hogy a külföldi szellemi tulajdonjog-védelem mennyire erős a hazaihoz képest. Kevésbé szívesen lép be egy olyan piacra, amelyen a szellemi tulajdonjog-védelem gyengébb, mint a hazai, minél közelebb esik a hazaihoz, annál szívesebben, ha pedig annál erősebb, akkor ez nem jelent korlátozó tényezőt. Az ötödik fejezetben ezt a feltételezett összefüggést vizsgálom meg empirikusan, országok egymás közti kereskedelmét mutató makroadatok alapján.

A negyedik és ötödik fejezet kulcskifejezése a nyitott gazdaságban, vagyis két egymással kereskedelmi kapcsolatban álló ország esetében már nem a szellemi tulajdonjog-védelem erőssége, hanem a relatív szellemi tulajdonjog-védelmi erősség. 


\section{A tudás terjedése és az IPR erőssége}

Az Általános Vámtarifa- és Kereskedelmi Egyezmény (GATT) 1994-ben befejeződő uruguayi fordulója hozta magával a TRIPS (Trade-Related Aspects of Intellectual Property Rights, a szellemi tulajdonjogok kereskedelemmel kapcsolatos vonatkozása) egyezmény aláírását. Az egyezmény a fejlett országok erős lobbytevékenységének eredménye volt. A fejlett országok arra a globális trendre kívántak reagálni, hogy a tudás-alapú gazdaságban megnövekedett a tudás szerepe a termelésben és a gazdasági növekedés motorjává vált. Ezt a funkcióját globálisan azonban akkor tudja csak megfelelő módon kifejteni, hogyha a megtermelt tudás védelméből minden ország egyaránt kiveszi a részét. A szellemi tulajdon megsértése, a szabadalombitorlás, a másolás, a hamisítás és a kalózkodás a fejlett országok vezető innovatív cégeinek évi milliárdos nagyságrendű bevételkiesést okoz. ${ }^{46} \mathrm{~A}$ szellemi tulajdonjog-védelem intézményének a szerepe a tudás országok közötti terjedésében nemzetközi kereskedelem, vegyes vállalatok alapítása vagy müködőtőke-beruházások által széles körben kutatott területe a közgazdaságtannak (Maskus - Penubarti 1995, Smith 1999, Ivus 2010).

A tudás közjószág-jellegü tulajdonságai (a kizárhatóság és a technikai értelemben vett rivalizálás hiánya) fontos következményekkel jártak a tudás előállításának ösztönzése esetében. A szabadalom intézménye képes volt a tudás termelésében legalább részlegesen feloldani az innovátorok és a társadalom közti érdekellentétet. Ha egy nyitott gazdaságot vizsgálunk, akkor a belföldi szellemi tulajdonjog-védelem nem óvja meg azonban a vállalatot attól, hogy termékeit a határain túl lemásolják, és ezáltal büntetlenül potyautazhassanak a hazai kutatásból származó költséges eredményeken. Mivel a határok nem zárhatóak le légmentesen, megakadályozandó, hogy emberek vagy javak, és velük együtt adott esetben gazdaságilag értékes tudás kiszivároghasson az országból, a hazai innovátorok számára fontos, hogy külföldön milyen védelmet élveznek szellemi tulajdonaik. Ha ugyanis kellően védettek, akkor hajlandóak hagyni a tudás külföldre szivárgását, talán még elő is segítik, például termékeik exportálásával, vállalataik külföldre telepítésével vagy licencszerződések által.

\footnotetext{
${ }^{46}$ A károkat természetesen meglehetősen nehéz pontosan számszerüsíteni. A National Intellectual Property Rights Coordination Center 2011 évi jelentésében (NIPRCC 2011, 19. o.) két számot idéz: a zeneipar 6,37, a filmipar 6,1 milliárd dollárnyi veszteséget szenvedett a kalóztevékenység miatt 2005-ben. Ezekben a példákban ugyan inkább a szerzői jog sérelme történt, és nem a szabadalmi védelemé, de ugyanezen tanulmány szerint például a különböző illegális weboldalakon árult gyógyszerek mintegy 50\%-a hamisítvány (u. o.).
} 
A szellemi tulajdonjogok (IPR, Intellectual Property Rights) védelmére szolgáló különbözö eszközök - mint például a szabadalmak, a védjegyek és a szerzői jogok - egyik célja az, hogy racionálissá tegyék az erőforrások beruházását a szellemi termékek termelésébe, amely „előmozdítja a tudomány és a művészetek fejlődését”. Ezt azáltal érik el, hogy „meghatározott időre a szerzőknek és feltalálóknak kizárólagos jogot biztosít[anak] írásaik illetve találmányaik felett” (David, 1992, az Egyesült Államok alkotmányát idézi). Mint a korábbi fejezetekben bemutattam, számos tanulmány vizsgálja, hogy a szabadalmi rendszer hogyan képes elősegíteni a technológiai tudás keletkezését.

A szabadalmi védelem által megteremtett mesterséges szükösség a szellemi termékek esetében azt is lehetővé tette, hogy kereskedni lehessen a szellemi termékekkel vagy éppenséggel tudást megtestesítő termékekkel, és ilyen módon a tudás térben elterjedhessen. Mint az első fejezetben bemutattam, a szabadalmi védelem korai előfutáraiként a „literae patentes" által megtestesített előjogok éppen a tudás nemzetközi terjedésére kívántak hatással lenni.

A szellemi tulajdon védelme tehát nem kizárólag az új szellemi termékek előállítóinak védelmét szolgálja, hanem az új tudás elterjedésének elősegítését is. A tisztázott tulajdonjogok elősegítik a kereskedelmet. A piaci árak, melyeket a kizárás lehetősége tesz érvényesíthetővé, nem csupán a hatékony termelést, hanem a hatékony elosztást is előállítják, és a piaci mechanizmus logikája szerint a szellemi termékek a kereskedelem segítségével megtalálják a leghatékonyabb felhasználási lehetőségüket.

Dolgozatom utolsó két fejezetében azonban nem a tudás szellemi termékek nemzetközi mozgása általi terjedése a vizsgálat célja. ${ }^{47} \mathrm{Az}$ országok között indirektebb módon, tudást megtestesítő termékek, magasan vagy speciálisan képzett munkaerő, vagy egész termelési folyamat áramlásával is terjedhet tudás. A következő két fejezetben azt kívánom megvizsgálni, hogy az eltérő nemzeti szabadalmi védelmi szabályozások, illetve azok változása hogyan befolyásolják a nemzetközi termékáramlást.

A feltételezésem az, hogy a nemzetközi termékforgalomra, és ezen keresztül az országok közötti tudásáramlásra az egyes országok szellemi tulajdonjog-védelmi szabályozása közti különbségek, illetve ezeknek a különbségeknek az időbeli változásai is hatással vannak. Ha valóban így van, akkor ez azt jelenti a tudást importálni szándékozó országok számára, hogy nemzeti szabadalmi szabályozásuk kialakításakor figyelemmel kell lenniük mind az exportőreiknél, mind pedig a más országoknál érvényes szabályozásra

\footnotetext{
${ }^{47}$ Nemzetközi licencszerződésekről lásd pl. Park - Lippoldt (2005), nemzetközi szabadalmaztatásról pedig Eaton - Kortum (1999)
} 
is. Ugyanakkor a nemzeti szabadalmi védelmi intézményrendszer finomhangolása egy új módja lehet a nemzetek közötti versenynek, és ezáltal egy új potenciális út a nemzetek, akár régiók versenyképességének növelésére. Az IPR-védelem változtatásával a tudás, mint termelési tényező mobilabbá válhat - hasonlóan a munkához vagy a tőkéhez -, vagy kevésbé mobillá - mint amilyenek a természeti kincsek. Második feltételezésem, hogy nem csak a különböző országok IPR védelmi rendszerének szigorúsága vagy engedékenysége a fontos befolyásoló tényező, hanem a kereskedelmi partnerek szabályozásának egymáshoz való viszonya: rövid elnevezéssel a relatív szellemi tulajdonjog-védelmi erősség, illetve ennek a változása. A 4. fejezetben ennek a hatását kívánom feltérképezni.

Ha bemutatható, hogy az IPR rendszer relatív erőssége, mint egy új eszköz a nemzeti kormányok kezében, képes befolyásolni a technológiák nemzetközi kereskedelmét, áramlását, akkor Ghosh szavaival élve egy “új merkantilizmusról” beszélhetünk, egy új eszközről, amely a nemzeti kormányzatokat hozzásegítheti a nemzetközi versenyben való jobb helytálláshoz (Ghosh 2003, 85.o).

A fejezet felépítése a következő: a 2. alfejezetben áttekintem a szellemi tulajdonjogvédelmi rendszerek nemzetközi termékáramlásra gyakorolt hatásának irodalmát. Itt mutatok rá arra, hogy a relatív IPR-védelem mennyire kevéssé vizsgált téma a szakirodalomban. A 3. alfejezetben felépítek egy modellt, ami ezt a paramétert beépíti a modellbe, és megmutatja hatásait. A modell által elöre jelzett hatások empirikus vizsgálatával a dolgozat következő fejezete foglalkozik majd.

\subsection{Irodalmi áttekintés}

A TRIPS megállapodás müködésének mintegy 15 éve alatt élénk elméleti vitákat indított el és táplált arról, hogy milyen módon fogja befolyásolni a tudásterjedést. A tudásátadás, ahogyan Park (2008, 299. o.) definiálja, „az a folyamat, melynek során technológiai know-how és a gyártás, illetve értékesítés joga az egyik szereplőtől a másikhoz átkerül, akár egy országon belül, akár országhatárokon átívelően”. Ebben és a következő fejezetben ezen belül a tudás országhatárokon átívelő terjedésére koncentrálok. Ahogyan Falvey - Foster (2006) megjegyzi, ez az országok közti tudásáramlás több módon is megtörténhet, a tudástranszfernek számos csatornája ismert és vizsgált: termékek nemzetközi kereskedelme, direktberuházás, joint venture, licencbe adás vagy a külföldi 
szabadalmaztatás. ${ }^{48}$ Ezek a külföldi piacra lépési formák a tudás átadója szempontjából egymás különböző kockázatokkal, költségekkel és hasznokkal bíró helyettesítői, alapos költség-haszon elemzés előzi meg a vállalat döntését a külpiacra lépési csatornák között. A disszertációmban a vizsgálódást szeretném leszükíteni a tudásterjedés egyetlen, indirekt formájára: a termékáramlásra. A magasabb vagy alacsonyabb technikai színvonalat, több vagy kevesebb tudást megtestesítő termékek nemzetközi kereskedelembe kerülésével akarva-akaratlanul a termékre vagy a gyártási eljárásra vonatkozó tudás is részben a termékkel együtt külföldre kerülhet. Bár az általam vizsgálni kívánt befolyásoló tényezők hatást gyakorolhatnak a tudásterjedés egyéb módjaira is, én csak a termékek nemzetközi kereskedelmére gyakorolt hatását kívánom elemezni.

A TRIPS megállapodások jelentősége abban rejlik, hogy bizonyos minimum követelményeket határoznak meg a tagországok számára, melyeknek azok szellemi tulajdonjog-védelmi szabályainak meg kell felelnie. Ez a megfelelési kényszer többnyire a fejlődő országokra volt hatással és azt eredményezte, hogy az addig érvényben lévő szellemi tulajdonjog-védelmi szabályaikat szigorúbbá tették, míg az új minimumkövetelmények a fejlett országok szabályozását nem jelentősen, de legalább is nem kötelezően változtatták meg. A fejlődő országok szabályozásában bekövetkezett általános erősödés pedig hatással volt ezen országoknak a fejlett országokkal való kereskedésére. Ennek a hatásnak a vizsgálatára a szakirodalomban az elmúlt csaknem két évtized alatt számos elméleti, modell-szintű, illetve empirikus vizsgálat született.

\section{Az IPR és nemzetközi kereskedelem összefüggéseit vizsgáló modellek típusai}

A témám szempontjából releváns irodalom az endogén növekedési elméletek körében vizsgálódik, amelyek megközelítése szerint a gazdasági növekedés üteme nem külső adottság, hanem vállalatok tudatos, profitorientált tevékenységének az eredménye. Ezen a körön belül is a $\mathrm{K}+\mathrm{F}$ alapú növekedési elméletek bírnak a jelen téma szempontjából jelentőséggel (Saggi 2002), amely elméletekben a növekedés fő mozgatója és meghatározója a tudástermelés és a tudásterjedés, röviden szólva a technológiai fejlődés: a gazdaság az által növekszik, hogy a vállalatok nagyobb profit reményében új technológiák kifejlesztésébe kezdenek, illetve számukra új technológiákat szereznek meg.

A modellek alapvetően két formában kezelik az innovációkat. A minőségi lépcsős (quality ladder) modellekben minden egyes iparágban a fejlesztés úgy történik, hogy a

\footnotetext{
${ }^{48}$ A tudástranszfernek további fontos csatornája lehet a képzett munkaerő nemzetközi vándorlása (Hoekman et al., 2005), ez azonban többnyire nem vállalati döntés.
} 
későbbi generációk minőségileg jobbak a korábbi generációnál, ami az alacsonyabb előállítási költségben fejeződik ki (Taylor 1993, Grossman - Helpman 1991, Glass - Wu 2007). Az $n$. generációs termék monopol eladója kiszorul a versenyből, és a terméke eltünik, ha valaki feltalálja az $n+1$. generációt, vagy pedig termékének egy imitációja születik meg. A választékbővítési modellekben (variety expansion) az innovációk bővítik a meglévő termékek számát (Chin - Grossman 1988, Glass - Wu 2007, Ivus 2011) a már meglévő termékek monopol előállítóit új innovációk nem szorítják ki a versenyből, csak az imitációk. A modellekben az IPR védelem erőssége hatással van a $\mathrm{K}+\mathrm{F}$ ráfordításokra, ezen keresztül az innováció mértékére. Az erősebb IPR védelem magasabb $\mathrm{K}+\mathrm{F}$ ráfordítást indokol, és a megnövekedett innováció a gazdasági növekedés gyorsulását eredményezi.

Zárt gazdaságokat vizsgálva világos, hogy az új technológia csak belülről, egy új innováció feltalálásával születhet meg, és a szabadalmi rendszer hatással van erre a folyamatra, mint ahogyan ezt a korábbi fejezetekben bemutattam. Egy nyitott gazdaság esetében azonban az új technológia érkezhet kívülről is, a fentebb említett valamely tudástranszfer-csatornák egyikén keresztül: ebben a fejezetben azt vizsgálom meg, hogy a szabadalmi védelem erőssége hogyan hat erre a folyamatra.

Ha az országok közötti tudásáramlásra koncentrálunk, akkor ezek a modellek általában az észak-dél kereskedelmi modellek logikáját követik, melyben egy fejlett észak és egy fejlődő dél állnak egymással kereskedelmi kapcsolatban. Az innovációk a fejlett országból származnak, a fejlődő országoknak viszont lehetőségük van a hozzájuk érkező tudást lemásolni, imitációkkal jelenhetnek meg a piacon (Chin - Grossman 1988, Zigic 1998, Ivus 2011). A modellek egy része statikus, parciális egyensúlyi környezetben vizsgálja a szellemi tulajdonjog-védelem szerepét (Chin - Grossman 1988, Deardorff 1992, Zigic 1998, Ghosh - Ishikawa 2010), míg egy másik része dinamikus és általános egyensúlyi modell (Helpman 1993, Taylor 1994, Ivus 2011). Az alábbiakban a modelleknek ezt a két csoportját mutatom be.

\section{Parciális egyensúlyi kereskedelmi modellek}

A parciális egyensúlyi modellek a vállalati döntésekre illetve az északi és déli vállalatok közötti stratégiai interakciókra koncentrálnak. Chin és Grossman (1988) modelljében az északi és a déli országot is egy-egy vállalat szimbolizálja, akik egy korábbi technológiával elő tudnak állítani egy terméket, amelyre mindkét országban kereslet van. Az északi vállalat tud csak innoválni, amivel költségcsökkenést érhet el. A modell a szabadalmi védelmet kétértékủ változóként tekinti: vagy van szabadalmi védelem vagy 
nincsen. Ha van, akkor nem lehetséges az imitálás, ha viszont nincsen, akkor a költségmentes imitálás biztosan megtörténik. A $\mathrm{K}+\mathrm{F}$ hatékonyság döntő tényezőnek bizonyul a modellben, amely azt mutatja meg, hogy egységnyi $\mathrm{K}+\mathrm{F}$ ráfordítás mekkora mértékben csökkenti a termelési költségeket. A modell azt jósolja, hogy a déli jólétet csökkenti a szabadalmi védelem bevezetése, kivéve hogyha a déli piac a teljes piac jelentős része, vagy hogyha a $\mathrm{K}+\mathrm{F}$ meglehetősen nagy hatékonyságú (12. o.). A déli szabadalmi védelem növekvő mértékü innovációra sarkallja az északi vállalatot, viszont torzítja a versenyt (monopol helyzetet, vagy legjobb esetben aszimmetrikus duopóliumot eredményez), és ezek együttes hatása a déli jólétre általában negatív. Az északi jólét mindenképpen nő a déli szabadalmi védelem bevezetésével, és leszámítva a meglehetősen alacsony $\mathrm{K}+\mathrm{F}$ hatékonyságú esetet, a globális jólét is növekszik.

Deardorff (1992) modelljében ha van délen szabadalmi védelem, akkor az északi innovátor monopol helyzetbe kerül, ha viszont nincs, akkor egy tökéletesen versenyző helyzetben találja magát. A modell szerint a lakosság észak és dél közti megoszlásának ismét jelentős szerepe van. Ha a lakosság kellően nagy része északon lakik, akkor a dél veszít a szabadalmi védelem bevezetésével, és általában a globális jólét viszont növekszik. A szabadalmi védelem még mindig kétértékü lehet csak, vagyis vagy van, vagy nincsen délen védelem, erőssége viszont mégis változónak tekinthető a modellben. Megmutatja ugyanis, hogy ha a lakosság átrendeződik, és kellően nagy hányada kerül északra, akkor a déli szabadalmi védelem már a globális jólétet is csökkenti. Globális jóléti szempontból tehát a szabadalmi védelmet érdemes a világ több és több országára kiterjeszteni egy bizonyos határig (a lakosság egyre nagyobb hányada kerül át a szabadalommal védett északra), de nem érdemes minden országra.

Zigic (1998) már explicit módon folytonos változóként tekint a déli szabadalmi védelem erősségére. A szabadalmi védelem erőssége azt határozza meg, hogy az északi költségcsökkentő innováció mekkora része fog túlcsorduló hatásként délen is megjelenni költségcsökkenésként. Hasonlóan Deardorffhoz, itt is lényeges szerepe van a lakosság megoszlásának, a túlcsorduló hatások modellbe építésével azonban megmutatható, hogy bizonyos határok között nemcsak a globális jólét nöhet, hanem a dél is nyerhet a szabadalmi védelem szigorításával. Bár ezek a modellek explicite a $\mathrm{K}+\mathrm{F}-\mathrm{re}$, és ezáltal az új innovációk megjelenésére adnak magyarázatot, nem pedig a kereskedelemre, úgy kell értelmeznünk ezeket, hogy amely innovációk előállnak, azok el is jutnak a fejlett feltaláló országból a fejlődő felhasználó országba. Ha a fejlődő országban nincsen szabadalmi 
védelem, akkor az ottani fogyasztók „minden újonnan feltalált termékhez kompetitív kínálatból jutnak hozzá" (Deardorff, 1992, 44. o.).

Ghosh és Ishikawa (2010) parciális egyensúlyi duopol modellje már explicit módon az északi innovátor vállalat azon döntésére koncentrál, hogy hogyan jelenjen meg innovatív termékével a déli piacon. A megjelenés két lehetséges fajtája az exportálás és a külföldi direktberuházás (FDI). Modelljében az FDI esetében áll fenn a lemásolás kockázata, export esetében nem. Két legfontosabb különbség a korábbiakhoz képest, hogy költséges imitálást tételeznek fel, valamint hogy a déli IPR védelem erösségét folytonos változóként kezelik. A déli vállalat számára a lemásolás nem egy automatikus folyamat, hanem költségekkel jár. Minél magasabb költséget vállal, annál jobban le tudja utánozni az északi költségcsökkentő innovációt. Ezt a lemásolási képességet, mely a déli vállalattól beruházást igényel, abszorptív kapacitásnak nevezik (Ghosh - Ishikawa 2010, 7. o.). Az innováció leutánzásának hatékonysága azonban nemcsak az endogén módon meghatározódó abszorptív kapacitástól függ, hanem a szellemi tulajdonjog-védelem erősségétől is. A szellemi tulajdonjog-védelmi erősség és az abszorptív kapacitás együttesen ugyanazt a szerepet töltik be, mint Zigic (1998) esetében a túlcsorduló hatások. A modell eredményeképpen az adódik, hogy ha az exportálással járó tranzakciós költségek nagyon alacsonyak, vagy nagyon magasak, akkor a délnek nem áll érdekében szigorítani az IPR védelmét. Mérsékelt tranzakciós költségek mellett azonban a dél nyerhet azon, hogyha szigorítja a szellemi tulajdonjog-védelmi rendszerét. Ez által nagyobb beruházásokra ösztönzi a déli vállalatot az abszorptív kapacitásba, az északi céget pedig a direktberuházás irányába mozdítja el.

\section{Általános egyensúlyi kereskedelmi modellek}

Az észak-déli kereskedelmi modellek másik nagy csoportjába a dinamikus, általános egyensúlyi modellek tartoznak. Ezek a modellek többnyire a nemzetközi kereskedelem ricardoi modelljére építenek, vagyis a specializáció és a kereskedelem az alternatív költségekbeli különbözőségek függvénye is. A modellek dinamikus volta következtében a termékek egy életciklust követnek. Miután megjelenik egy innováció északon, északról megfelelő körülmények között a termék eljut a déli országba. Ha ott sikerül lemásolni, akkor a termelés átkerül délre az alacsonyabb termelési költségek miatt, így végül az eredeti exportáló innovátor válik a termék importálójává. A termékek, és a termelés országok közötti áthelyeződése megváltoztatja az alternatív költségeket és a specializációt is. A dinamikus általános egyensúlyi modellek lehetőséget adnak arra, hogy az IPR 
védelem kereskedelemre gyakorolt hatásának különböző összetevőit elkülönítésük, és olyan hatásokat is azonosítani tudnak, melyek a parciális egyensúlyi modellekben nem jelenhettek meg.

Helpman (1993) általános egyensúlyi modelljében hasonló eredményre jut, mint a Chin - Grossman (1988) parciális modell: „Ki nyerhet a kevésbé fejlett országok szellemi tulajdonjogának szigorításával?” - teszi fel a kérdést. „ha bárki nyerhet, az nem a dél lesz” (Helpman 1993, 1274. o.). Modelljében konstans innovációs rátát feltételezve a déli IPR védelem szigorítása a cserearányokat egyértelmüen észak javára változtatja meg. A termelés ezért átrendeződik a magasabb árú északi termékek irányába, ez pedig csökkenti a déli jólétet és egyben a hatékonyságot is. Ha az innovációs ütem lassú, akkor mind a dél, mind pedig észak jólétét csökkenti a déli védelem szigorítása. Ha viszont gyors az innovációs ütem, akkor észak nyerhet a szigorúbb déli védelemmel, bár dél továbbra is veszít.

Taylor (1994) minőségi lépcsős általános egyensúlyi modelljében a két ország szellemi tulajdonjog-védelme lehet aszimmetrikus vagy szimmetrikus. Az elöbbi eset azt jelenti, hogy minden ország csupán a nála előállt kutatási eredményeket részesíti védelemben, a szimmetrikus esetben pedig a másik országban előállított tudás ugyanolyan védelemben részesül, mint az otthoni. Az otthoni ország szempontjából tehát az áttérés az aszimmetrikus védelemről a szimmetrikusra az IPR védelem külföldi erősödésével egyenértékü. Az aszimmetrikus védelemről a szimmetrikus védelemre áttérés az exportlehetőségek bővülését jelenti. A fejlett országnak lehetősége nyílik arra, hogy jobban kihasználja a $\mathrm{K}+\mathrm{F}$ területén a komparatív elönyét, mert a kutatás-fejlesztés eredményeit a szimmetrikus védelem mellett nyugodtan exportálhatja külföldre. A szimmetrikus védelem a tényezőárak kiegyenlítődéséhez vezet, elősegíti a specializációt a kutatás-fejlesztésben és a termelésben, hozzájárul a technológia és a termékek nemzetközi áramlásához, és nagyobb mértékü globális K+F-re ad lehetőséget.

Ivus (2011) modelljében a déli IPR szigorítás már nem egyértelmüen hátrányos a dél szempontjából. Az IPR védelem déli erősödése Ivus (2011) alapján négyféle jól elkülöníthető hatáson keresztül befolyásolja az északi exportot délre. Az első hatás a piackiterjesztő hatás (market expansion effect). Ha délen szigorodik a szabadalmi védelem, akkor az északi innovátor vállalatnak lehetősége nyílik egy a korábbinál nagyobb piacon monopol profithoz jutni. A piackiterjesztő hatás az északi vállalatot az export növelésére ösztönzi. A második hatás a piacierő-hatás (market power effect). Ha szigorodik a déli szabadalmi védelem, akkor csökken a lemásolás valószínüsége, az északi exportőr 
nagyobb biztonságban érezheti az általa birtokolt tudást. A kereslet nemcsak hogy növekszik, hanem árrugalmatlanabbá válik. A rugalmatlanabb kereslet mellett az északi vállalatnak megéri az árakat növelni, az exportot pedig csökkenteni. Ezt a két hatást már korábban Maskus és Penubarti (1995) is azonosították empirikus vizsgálataik során. Azt találták, hogy a két ellentétes hatás közül a piackiterjesztő hatás dominál, ha délen sok nagyobb imitációs képességü és versenyképes cég van jelen, míg kisebb, kevésbé versenyképes és alacsonyabb imitációs képességgel bíró dél esetén inkább a piacierö-hatás a jelentősebb (Maskus - Penubarti 1995, 230. o.). Ez a két hatás a parciális egyensúlyi modellekben is megjelenik. Az IPR védelem erösítésével kapcsolatos harmadik hatás a piachígulási hatás (market dilution effect). Ahogyan nő a délen megjelenő északi termékek száma, úgy dél költségvetésének egyre kisebb hányadát fordítja északi termékekre, ami az északi termékek iránti keresletet végső soron csökkenti. A negyedik hatás pedig a cserearány-hatás (terms of trade effect), ami az előző három együttes hatása a relatív bérekre. Mivel dinamikus és általános egyensúlyi modellről van szó, a termelés és annak időbeli áthelyeződése hat a bérszínvonalra mind északon, mind pedig délen. Az erősödő IPR védelemnek a relatív bérszínvonalra gyakorolt hatása nem egyértelmü. Ha az egyensúlyi relatív északi bér csökken, akkor ez növeli az exportot, ha nő, akkor az export visszaesik (Ivus 2011). Modelljéből azt a következtetést vonja le, hogy amennyiben az egyes iparágak különböznek imitációs képességük szerint, akkor a déli IPR védelem szigorítása növelheti összességében véve az északi exportot, méghozzá úgy, hogy azokban az iparágakban, ahol az imitáció veszélye magasabb, az export növekszik, míg az alacsonyabb imitációs kockázatú iparágakban az export csökken (Ivus 2011, 203. o.).

Az ebben a fejezetben felépítendő modell a parciális egyensúlyi modellek logikáját követi, vagyis a vállalati export-döntésre koncentrál. Chin - Grossman (1988) és Deardorff (1992) modelljeihez hasonlóan én is költségmentes imitációt feltételezek, és egy változatosság-bővítő modellben keresem az IPR védelem hatását. Különbözöm tőlük azonban annyiban, hogy az innovációt exogénnek tekintem, vagyis azt feltételezem, hogy az IPR védelem nem gyakorol hatást a $\mathrm{K}+\mathrm{F}$ ráfordításokra, csupán arra a döntésre, hogy az elóállt innovációt elviszem-e a déli országba, vagy sem. A K+F-re gyakorolt hatás kiiktatásával a modell a nemzetközi kereskedelemre gyakorolt hatásra tud fókuszálni. Az IPR védelem erőssége ezektől a modellektől eltérően többértékü lehet. A megközelítésem hasonlít Zigic (1998) és Ghosh - Ishikawa (2010) megközelítéséhez, amennyiben az én modellemben sem automatikus a találmányok lemásolása, hanem egy olyan, a déli 
országra jellemző tényezőtől függ, mint amit Zigic tudás-túlcsordulásnak, Ghosh Ishikawa pedig abszorptív kapacitásnak nevez. Az én modellemben azonban ez a tényező exogén, de iparág-függő. Ez utóbbi két modelltől eltérően az én modellemben nem jelenítem meg a külföldi direkt-beruházást, mint az exportálás alternatíváját, így ismét csak nem biztos, hogy az innovátor északi országban elöállt minden innováció eljut a déli országba. Hasonlóan Taylor (1994) és Ivus (2011) modelljeihez, azt a határon lévő iparágat keresem, ameddig érdemes elmennie az északi országnak az exportálásban. Az ezt befolyásoló tényező azonban nem pusztán a déli IPR védelmi erősség, mint a fentebb említett modellek mindegyikében, hanem a déli védelem relatív erőssége az északi védelemhez képest. Goenner - Silva (2009) szintén a nemzetközi kereskedelem befolyásoló tényezőinek kereskedelmi partnerek közötti relatív különbségére koncentrál, mint a kereskedelem volumenének meghatározójára, bár nem az IPR védelmi rendszer erősségét használja befolyásoló változónak. Modelljükben azt találják, hogy a tényezőellátottság nemzetközi egyenlőtlensége csökkenti a nemzetközi kereskedelmet (15.o.). Ebben a fejezetben a déli ország relatív IPR védelmi erősségét északi kereskedelmi partneréhez képest, mint relatív tényezőellátottságot, magyarázó változóként használva kívánom megmutatni, hogy a fejlődő déli országok relatív felzárkózása vagy éppen lemaradása az IPR védelem szempontjából a fejlett északhoz képest hogyan befolyásolja a termékáramlást északról délre.

Mint ahogyan az előző alfejezetben bemutattam, a szellemi tulajdonjog-védelem és nemzetközi kereskedelem összefüggéseit vizsgáló modellekben az IPR védelem erőssége úgy jelenik meg, mint annak a valószínűsége, hogy a fejlett országban előállt tudás „kiszivárog”, a technológia ismertté válik a fejlődő országban, és a termelés végül is a fejlődő országba vándorol. Amikor a fejlett országbeli termelő az exportálás profitabilitását latolgatja, akkor a várható haszonnal szembeállítja ennek a kiszivárgásnak a valószínűségét. Amennyiben azonban a fejlett országbeli szellemi tulajdonjog-védelem sem tökéletes, akkor ez a „kiszivárgás” bizonyos valószínűséggel exportálás nélkül is megtörténhet, a használt technológia kitudódhat és így a termelés ugyanúgy elvándorolhat a fejlődő országba.

A nem tökéletes szellemi tulajdonjog-védelemmel rendelkező déli országban egy innovatív terméket oda exportálva, mondjuk, $60 \%$ eséllyel megjelenik egy nem jogsértő imitációja, ami csökkenti az északi ország profitját. Ha a déli országban szigorodik a szabályozás, ez a valószínűség lecsökkenhet mondjuk 50\%-ra. A déli ország IPRvédelmének erősödése csökkenti az innovatív termék lemásolásának az exportálásból származó többletkockázatát. Tegyük fel azonban, hogy a védelem északon, bár jobb ugyan, 
mint délen, de nem tökéletes. A kiszivárgás esélye exportálás nélkül is fennáll, mondjuk 40\%, ami szintén változhat. Ha északon drasztikus szigorítás történik, és az imitálás esélye 20\%-ra csökken, akkor a délre történő exportálásból származó többletkockázat valójában növekedett, a déli szabályozás abszolút erősödésének ellenére is. A többletkockázat mértéke tehát nem csupán a déli vagy az északi szabályozás abszolút erősségétől függ, hanem kettőjük viszonyától, illetve annak változásától is. Dél akkor kerülhet kedvezőbb helyzetbe északhoz képest, ha a szabályozás nem csak, hogy szigorodott, de nagyobb mértékben szigorodott, mint északon. Ezt értem a relatív IPR-védelem erösödése alatt.

A szellemi tulajdon eltérő szerepet játszik a különböző termékek termelésében, nagyobb jelentősége van a high tech mint a low tech termékek esetében. A szellemi tulajdonjogvédelem erősödésének is eltérő módon kell hatással lennie a különböző féle termékek nemzetközi kereskedelmére.

A következőkben felépítek egy modellt, amely ennek a relatív IPR-védelemnek a szerepét mutatja meg.

\subsection{A modell}

A modellben két ország szerepel: egy fejlett észak és egy fejlődő dél. Északon egy innovátor vállalat van, aki high és low tech termékeket gyárt, egyszerűség $(z)$ szerint rendezve $(z=0$ : legbonyolultabb, $z=1$ : legegyszerübb). Az ő exportálási döntését akarjuk megvizsgálni. A kereslet legyen mindkét országban lineáris: $p_{e}=a-\frac{b}{m_{e}} \cdot q_{e}$ az északi, exportáló országban, illetve $p_{i}=a-\frac{b}{m_{i}} \cdot q_{i}$ a déli, importőr országban, ahol $a ; b ; m_{e} ; m_{i}>$ 0 konstansok, és $m_{e}>m_{i}$ az exportáló és az importáló ország jövedelemszintjét jelölik! Egy adott áron tehát azt feltételezem, hogy a fejlett országban mindig nagyobb a kereslet az egyes termékek iránt, mint a fejletlen országban. A termékek előállítási költsége $M C=c>$ 0 . Az északi termelő monopólium, így meghatározható a monopolprofitja északon és amennyiben megjelenik ott - a déli piacon $\left(\Pi_{\mathrm{e}}\right.$ és $\left.\Pi_{\mathrm{i}}\right)$. A monopolhatalma az innovatív termékeire lévő szabadalmainak következménye.

A déli ország vállalatai lemásolhatják az északi termékeket, amelyekkel az északi vállalat megjelenik náluk, feltéve, hogy képesek rá, illetve hogy jogilag kivitelezhető. Amennyiben a termékét lemásolják, imitálják, akkor elveszítheti ezt a profitot. Tételezzük fel, hogy amennyiben sikeres imitáció történik, akkor az északi vállalat egy tökéletesen 
versenyző helyzetben találja magát egy olyan piacon, ahol immár mindenki $M C=c$ határköltséggel termel.

Tegyük fel, hogy imitáció csak délen történhet, továbbá, hogy a déli imitáció nem veszélyezteti az északi profitlehetőségeket (délen még el lehet adni az „Adiadas”, a „Plima” vagy a „Nikei” márkájú hamisított Adidas, Puma és Nike cipőket, de északon nem lehetne)!

Legyen $G$ a déli ország abszorptív kapacitása, vagyis hogy milyen könnyen tudja lemásolni az északról érkező termékeket $(G=0$ : biztos nem képes lemásolni, $G=1$ : biztosan sikerül lemásolnia).

Rendezzük a termékeket bonyolultság szerint csökkenően! Feltételezhetjük, hogy a high tech termékek bonyolultabbak, mint a low tech termékek. Az általam felépített modellben azonban az egyszerüséget vagy bonyolultságot folytonos változóként kezelem, és e dimenzió mentén megengedem a két termékcsoport keveredését: a high tech termékek között is lehetnek egyszerübbek, és a low tech termékek között is lehetnek bonyolultabbak. A bonyolultság növelésével tehát nem elvágólagosan különül el egymástól a két termékcsoport, hanem az egyre bonyolultabb termékek között egyre nagyobb arányban találunk high tech termékeket.

Mind a high tech, mind pedig a low tech termékek esetén tegyük fel, hogy a $z=0$ egyszerüségü (legbonyolultabb) terméket biztosan nem sikerül lemásolni, míg a $z=1$ egyszerüségü (legegyszerübb) terméket pedig biztosan képesek lemásolni. Minél kevésbé bonyolult egy termék, annál könnyebb lemásolni, vagyis $G z$-ben növekvő. Egy tetszőleges $z$ egyszerüség kijelöl egy $G$ lemásolási valószínűséget úgy, hogy a $(0 ; z)$ egyszerüségü termékeket csak ennél kisebb, a $(z ; 1)$ egyszerüségü termékeket viszont ennél nagyobb valószínűséggel tudják lemásolni. Ha a bonyolultság nő ( $z$ csökken), akkor ez csökkenti $G$ értékét. Nő tehát azoknak a termékeknek a köre, melyeket valószínűleg sikerül lemásolni. Mivel a high tech termékek között inkább bonyolult, a low tech között pedig inkább egyszerü termékek vannak, ezért azt feltételezem, hogy a legegyszerűbb terméktől kezdve a termékbonyolultság növelése erősebben csökkenti a lemásolási valószínűséget a high tech termékek esetében, mint a low tech termékeknél.

A lemásolás technikai lehetősége (képes vagyok-e lemásolni egy a piacomon megjelenő új terméket?) tehát függ a termék jellegétől (high tech vagy low tech), valamint a bonyolultságától. A fejlődő déli importör ország esetében $G(j, z)=z^{r_{j}}$, ahol $j=H ; L$ 
(high tech vagy low tech), továbbá $r_{H}>1>r_{L}>0$. A lemásolás valószínüsége és a termékbonyolultság összefüggését az 5.1. ábra mutatja grafikusan.

4.1. ábra. A déli abszorptív kapacitás a termékbonyolultság függvényében

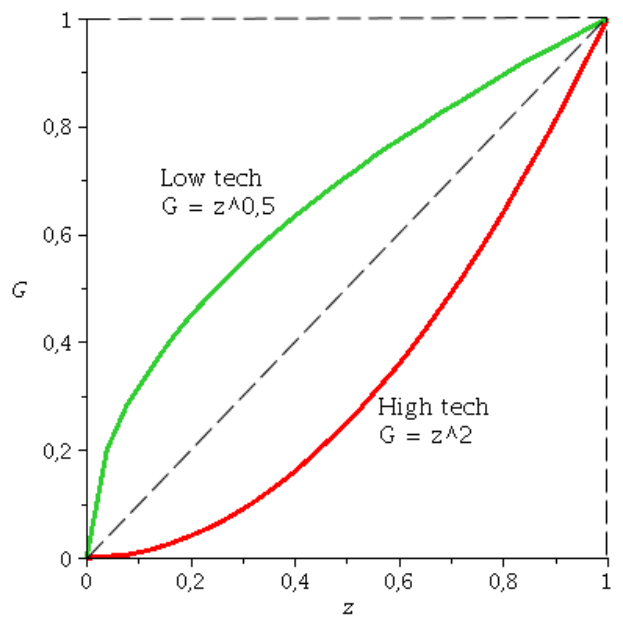

Forrás: saját szerkesztés

A déli imitáció megjelenése azonban nem csak az innovatív északi termék lemásolásának technikai lehetségességétől függ, hanem attól is, hogy az imitáció nem szabadalom-bitorló termék-e, vagyis, hogy jogilag kivitelezhető-e, hogy egy déli cég legálisan megjelenjen a piacon egy imitációval. Jelölje $\alpha_{i}$ a termék déli lemásolásának jogi lehetőségét! Ha tehát $\alpha_{i}=0$, akkor jogilag egyáltalán nem lehetséges a lemásolás, ha pedig $\alpha_{i}=1$, akkor egyáltalán nincsen jogi akadálya. Az imitáció levédethető, vagyis nem szabadalom-bitorló a déli országban $1>\alpha_{\mathrm{i}}>0$ valószínüséggel. Az $\alpha_{\mathrm{i}}=0$ tehát egyben a tökéletes szabadalmi védelmet is jelenti $\left(1-\alpha_{i}=1\right), \alpha_{i}=1$ esetében pedig egyáltalán nincsen szabadalmi védelem a déli országban. A modellben tehát $1-\alpha_{i}$ a déli szellemi tulajdonjogi (IPR) védelmi rendszer erősségét jelöli. A fejlődő országbeli IPR védelem szigorodásával $\alpha_{i}$ csökken, vagyis $1-\alpha_{i}$ emelkedik.

\subsubsection{Imitációs kockázat délen}

A déli vállalat sikeres imitációt tud végrehajtani, hogyha képes az innovatív termék lemásolására, ugyanakkor jogilag sincs akadálya, hogy megjelenjen a piacon: ennek valószínüsége a fentiek alapján $G \cdot \alpha_{i}$. A sikeres déli imitáció az északi innovatív vállalatot tökéletesen versenyző helyzetbe hozza a déli piacon, és a profitját eltünteti. Az imitáció veszélye csak azon termékek esetén fenyegeti északot, amelyeket exportál délre. 
Ha az északi cég úgy dönt, hogy egy tetszőleges $z$ egyszerüségü termékével megjelenik a déli piacon, akkor mérlegelnie kell ennek várható hasznait és költségeit. A várható haszon a déli monopolprofit, csökkentve a piacra lépés költségeivel, melyet most fix költségnek tételezek fel, mindez súlyozva a sikertelen déli imitáció valószínüségével: $\left(\Pi_{i}-F C\right) \cdot\left(1-G \alpha_{i}\right)$. Várható költségként az innováció költségét nem tekinthetjük, mivel az innovatív termék már létezik, és az északi piacon már be van vezetve. A várható veszteség ezért a sikeres lemásolás valószínűségével súlyozott piacra lépési fix költség $F C \cdot G \cdot \alpha_{i}$. Akkor érdemes tehát exportálni, ha

$$
\left(\Pi_{i}-F C\right) \cdot\left(1-G \cdot \alpha_{i}\right) \geq F C \cdot G \cdot \alpha_{i},
$$

ahonnan adódik, hogy

$$
G \cdot \alpha_{i} \leq \frac{\Pi_{i}-F C}{\Pi_{i}}
$$

Az egyenlőtlenség bal oldalán a sikeres déli imitáció valószínűsége áll. Átrendezve az (9) egyenlőtlenséget azt kapjuk, hogy azokat a termékeket érdemes exportálni az egyes iparágakban, amelyekre teljesül, hogy

$$
G \leq \frac{\Pi_{i}-F C}{\Pi_{i}} \cdot \frac{1}{\alpha_{i}} .
$$

Meghatározható az „imitációs határkockázat”, $G^{*}$, amelyet még éppen érdemes vállalni az exportőrnek, melyre (9), illetve (10) egyenlőséggel teljesül. Mivel $G$ szigorúan monoton növekvő $z$-ben, valamint folytonos, ezért meghatározható az a $z^{*}$ bonyolultság (a high és a low tech iparágakban külön-külön), amelynél bonyolultabb (azaz nehezebben imitálható) termékeket még érdemes exportálni, egyszerübbeket azonban már nem. Ez a határon lévő termékbonyolultság a

$z_{H}^{*}=\alpha_{i}^{-\frac{1}{r_{H}}} \cdot \sqrt[r_{H}]{\frac{\Pi_{i}-F C}{\Pi_{i}}}$ a high-tech, és $z_{L}^{*}=\alpha_{i}^{-\frac{1}{r_{L}}} \cdot \sqrt[r_{L}]{\frac{\Pi_{i}-F C}{\Pi_{i}}} \quad$ a low-tech termékek esetében. $^{49}$

Érdemes szót ejteni a $\frac{\Pi_{i}-F C}{\Pi_{i}}$ hányadosról, mint a modell egyik fontos eleméről. Nevezzük el ezt az arányt П-hányadnak! A hányados számlálójában az exportálásból származó potenciális nettó profit (termelői többlet) szerepel, míg a hányadosban a bruttó monopolprofit. Minél nagyobb az exportálás fix költsége a várható profithoz képest, ez a

\footnotetext{
${ }^{49}$ Az iparágak bonyolultság szerinti éles szétválasztása azt eredményezné, hogy egy bizonyos imitációs határkockázat alatt csak high tech termékeket lenne érdemes exportálni, és az imitációs határkockázat emelkedésével lenne csak érdemes áttérni a low tech termékekre.
} 
mutató annál alacsonyabb lesz. Két okom van feltételezni, hogy a modellnek ezen mutatója valójában meglehetősen alacsony értékeket vesz fel. Egyrészt a külpiacon szerezhető profit $\left(\Pi_{i}\right)$ a modell szerint fordított arányban áll az importőr ország jövedelmi szintjével. Mivel az importáló országok a fejlődő országok, ezért ott alacsony jövedelmi szintet feltételezünk. Ha az exportpiacra lépés fix költsége országtól független, akkor minél szegényebb ország piacán kíván megjelenni a fejlett országbéli termelő, annál alacsonyabb lesz a várható profit, és így a fenti mutató értéke is. Másodsorban, hosszú távon ugyan a monopolhelyzet a fix költségeket jóval meghaladó profitokat is eredményezhet (feltéve persze, ha tartósan fennmarad a monopolhelyzet, azaz nincsen sikeres imitáció), a modellt viszont egy egyperiódusos modellként építettem fel, vagyis csak egy időszakbeli profit ellentételezheti a fix költségeket. Ebben az esetben azonban ezek nagyságrendje vélhetően jóval közelebb esik egymáshoz, ami ismét csak abba az irányba mutat, hogy a fenti mutatószám alacsony értékeket vesz fel. Fontos tulajdonsága a П-hányadnak, hogy a vállalat számára adottságként kezelendő a modellben, ország- illetve piacfüggő, hogy mekkora értéket vesz fel.

Nézzük most meg a modellben, hogyan hat az északi vállalat exportálási döntésére a déli IPR védelem szigorodása! Visszatérve a (9) egyenlethez, a déli IPR védelem szigorítása (vagyis $\alpha_{\mathrm{i}}$ csökkentése) minden egyéb változatlansága mellett csökkenti annak valószínüségét, hogy délen elő tudnak állni egy nem szabadalom-bitorló imitációval. Ez növeli a várhatóan profitabilisan exportálható termékek körét, tehát $z^{*}$ emelkedik: $\frac{\partial z^{*}}{\partial \alpha_{i}}<0$

Tekintsük a (9) egyenlet bal oldalát valószínűségként, és ábrázoljuk $G$ függvényében! A déli IPR-erösödés hatására a függvény meredeksége csökken, laposabban emelkedik. A $G$-től függelten aktuális П-hányad jelöli ki az imitációs határkockázatot $\left(G^{*}\right)$, amiből a határon lévő termékbonyolultság $\left(z^{*}\right)$ rögtön következik. Tekintsük meg a 4.2. ábrát! 
4.2. ábra. A déli IPR védelem erősödésének hatása

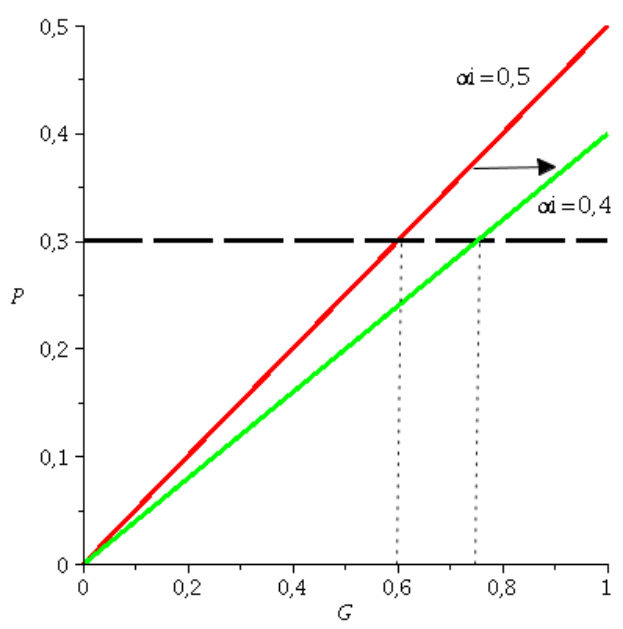

Forrás: saját szerkesztés

Az ábrán szaggatott vonallal jelölt függvény a П-hányad, az ábrán ennek értékét 0,3ra vettem. Az eredeti helyzetben az ábrán a déli IPR-védelem $\alpha_{i}=0,5$, emellett a vállalható imitációs határkockázat $G^{*}=0,6$, ebből pedig rögtön adódnak a határbonyolultságok a két iparág esetére az $r_{H}$ és az $r_{L}$ ismeretében. Ha a déli védelem szigorodik, és $\alpha_{\mathrm{i}}^{\prime}=0,4$, akkor az imitációs határkockázat emelkedik $G^{*}=0,75$-re.

\subsubsection{Kettős imitációs kockázat: északon és délen is megjelenhet imitáció}

Tételezzük most fel, hogy az IPR védelem északon sem tökéletes. Előfordulhat, hogy a déli piacot nem egy sikeres déli, hanem egy sikeres északi imitáció miatt veszíti el az eredeti monopol vállalat. ${ }^{50}$ Tegyük fel továbbá, hogy fordítva továbbra sem fordulhat elő, a déli imitáció nem fenyegeti a cég északi monopolhelyzetét. Az imitációt úgy értelmezem, hogy szabadon hozzáférhetővé válik a technológiai tudás egy közeli helyettesítő termék gyártásához. Az imitátor vállalat nem szabadalmaztatja ugyan a saját imitációját, viszont az nem is szabadalom-bitorló. A tudás „kiszivárog”, szabadon elérhetővé válik északon, és így a gyengébb védelemmel rendelkező délen is. Feltételezem, hogy északon, bár már nem tökéletes a szabadalmi védelem, azért szigorúbb, mint délen, tehát $0<\alpha_{\mathrm{e}}<\alpha_{\mathrm{i}}<1$. Az

\footnotetext{
${ }^{50}$ Egy sikeres északi imitációval természetesen az északi monopolprofitot is elveszti. Az északi imitáció hatása az északi piacon az exportálási döntéstöl függetlenül érvényesül, vagyis az exportálási döntést csak annyiban befolyásolja, amennyiben az exportálás várható hasznaira és költségeire hatással van.
} 
észak-dél kereskedelmi modellek mind úgy kezelik az északi országot, mint ahol a szellemi tulajdonjog-védelem tökéletes, vagyis $\alpha_{e}=0$.

A fejlett észak, az exportáló ország esetében feltételezem a nagyobb abszorptív kapacitást is a déli, importőr országhoz képest. Az egyszerüség kedvéért tegyük fel, hogy északon technikailag biztosan képesek lemásolni egy innovációt, vagyis hogy $G_{e}=1$ ! Az északi vállalatnak most azokat a termékeket éri meg exportálni délre, amelyek esetében

$$
\left(\Pi_{i}-F C\right) \cdot\left(1-G \cdot \alpha_{i}\right) \cdot\left(1-\alpha_{e}\right) \geq F C \cdot\left(G \cdot \alpha_{i}+\alpha_{e}-G \cdot \alpha_{i} \alpha_{e}\right) .
$$

A bal oldal most is az exportálásból szerezhető nettó monopolprofit, súlyozva annak a valószínűségével, hogy sem észak, sem dél nem áll elő nem-szabadalombitorló imitációval. A jobb oldalon pedig ismét az exportálás fix költsége található súlyozva ezúttal annak a valószínűségével, hogy vagy az észak, vagy a dél sikeres imitációt hajt végre. Bár az export-döntéstől nem függ egy sikeres északi imitáció elöállásának valószínűsége, fordítva viszont igen. A (8) egyenlethez képest a bal oldalon szereplö várható monopolprofit csökken, mivel nő a sikeres imitáció megjelenésének valószínűsége: már nem csak déli, hanem északi imitátorok is beszállnak az imitációk piacán zajló versenybe. A várható költség ugyanakkor növekszik, ugyanezen okból. A fenti egyenlőtlenség alapján az imitációs határkockázatot most az alábbi egyenlet megoldásaként kapjuk:

$$
G \cdot \alpha_{i}+\alpha_{e}-G \cdot \alpha_{i} \alpha_{e}=\frac{\Pi_{i}-F C}{\Pi_{i}} .
$$

Egy hasonló kifejezés adódott a déli imitációt megengedő (9) összefüggéshez. Az egyenlőség bal oldalán a sikeres imitáció megjelenésének valószínüsége található. Most azonban, hogy északon és délen is megjelenhet az imitáció, ez a valószínüség nőtt. Hogy láthassuk miért, alakítsuk át a bal oldalt:

$$
G \cdot \alpha_{i}+\alpha_{e}-G \cdot \alpha_{i} \alpha_{e}=G \cdot \alpha_{i} \cdot\left(1-\alpha_{e}\right)+\alpha_{e}=\alpha_{e} \cdot\left(1-G \cdot \alpha_{i}\right)+G \cdot \alpha_{i}>G \cdot \alpha_{i} .
$$

Látható, hogy a kifejezés mind az importőr, mind pedig az exportőr ország IPR védelmének csökkenő függvénye. Akárcsak annál az esetnél, amikor csupán a déli IPR védelem változását engedtük meg, most is ábrázoljuk külön a két oldalt! A bal oldalon lévő kifejezés mind G-ben, mind $\alpha_{i}$-ben, mind pedig $\alpha_{e}$-ben növekvő. Változatlan П-hányad mellett tehát $\alpha_{i}$ és $\alpha_{e}$ egyidejü csökkenését $G$ emelkedése ellensúlyozhatja. Rendezzük a (12) egyenletet, emeljük ki G-t belőle!

$$
\alpha_{e}+G \cdot\left(\alpha_{i}\left(1-\alpha_{e}\right)\right)=\frac{\Pi_{i}-F C}{\Pi_{i}}
$$


Ismét egy $G$-ben lineáris függvény adódik. Ábrázoljuk ismét a sikeres imitáció valószínüségét (az egyenlet bal oldalát) rögzített $\alpha_{i}$ és $\alpha_{e}$ mellett, $G$ függvényében, és nézzük meg, hogyan hat a paraméterek változása! A déli védelem változása továbbra is csak a meredekséget változtatja meg, az északi védelem változása azonban a tengelymetszetet és a meredekséget egyaránt.

4.3. ábra. A déli és az északi IPR védelem együttes erősödésének hatása

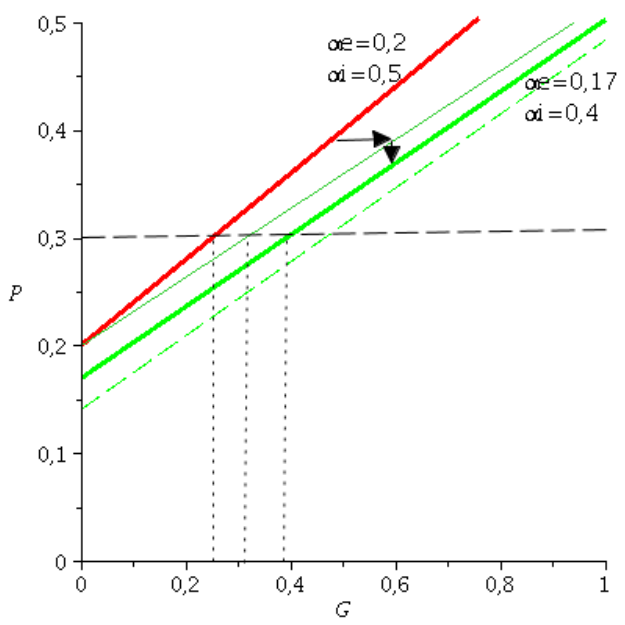

Forrás: saját szerkesztés

A legfelső függvény a kiinduló helyzet, legyen $\alpha_{i}=0,5$ és $\alpha_{e}=0,2$ ! Ismét bejelöltem ugyanazt a 0,3-es П-hányadot, hogy megkapjam az ábrán a vállalható imitációs határkockázatot: $G^{*}=0,25$. Változatlan erősségü északi védelem mellett a déli védelem erősödése $\alpha_{i}^{\prime}=0,4-$ re a függvényt jobbra elfordítja (mint ahogyan a 4.2. ábrán is), az új imitációs határkockázat tehát magasabb az eredetinél: $G^{*}=0,31$. Az északi védelem a függvény tengelymetszete. A modell azt mutatja, hogy a külföldi IPR védelem erősségén kívül a belföldi is befolyásolja az exportálási döntést. A hazai védelmi erősségnek olyannyira fontos szerepe van a modell szerint, hogy amennyiben $\alpha_{e}$ magasabb a Пhányadnál, akkor egyáltalán nem érdemes exportálni. Az északi védelem szigorodása, az ábrán $\alpha_{e}{ }^{\prime}=0,17$-re, megváltoztatja a tengelymetszetet és a meredekséget is. Az alsó vastagított függvény jelöli a déli és északi szimultán szabadalmi szigorodás hatásaként előálló új imitációs határkockázatot: $G^{* ”}=0,39$. A legalsó szaggatott vonal azt mutatja, mi történt volna adott mértékủ déli szigorodás mellett egy erősebb északi szigorítás esetén. Az erősebb északi szigorítás (mondjuk $\alpha_{e}{ }^{\prime}=0,14-$ re) még jobban kitolná az imitációs határkockázatot, $G^{*}$ ' $=0,47$-re. 


\subsubsection{A relatív IPR védelem}

A modell azt mutatja, hogy az exportálási döntés szempontjából nem csupán az importáló országbeli IPR védelem erőssége fontos, hanem az exportőr országbeli erősség is. A következőkben megvizsgálom, hogy a két ország védelmének nem csak az abszolút nagysága, hanem a viszonyuk, illetve ennek változása milyen hatással van a termékáramlásra.

A relatív IPR védelmi erősséget a modellben egyszerűen csak úgy definiálom, mint

$$
\omega=\frac{\alpha_{e}}{\alpha_{i}} .
$$

A szabadalmi védelemre vonatkozó eredeti feltétel miatt $\left(0<\alpha_{e}<\alpha_{i}<1\right)$ a kiindulásnál $0<\omega<1$. Ha mindkét országban megengedjük a szabadalmi védelem szigorodását egymástól függetlenül, akkor megkülönböztethetjük a fejlődő exportőr országok két csoportját az $\omega$ viselkedése alapján. Az egyik csoportot nevezhetnénk felzárkózóknak. Ilyennek minősítünk egy fejlődő országot akkor ha IPR védelme nagyobb mértékben nő, mint fejlett kereskedelmi partneréé úgy, hogy $0<\omega_{0}<\omega_{1}<1$. Lemaradónak nevezhetnénk azokat a fejlődő országokat, ahol az IPR védelem kisebb mértékben nő, mint fejlett kereskedelmi partnerénél, vagyis $0<\omega_{1}<\omega_{0}<1 .^{51}$ Vizsgáljuk meg, hogy mit eredményez a $\omega$ változása $G^{*}$ tekintetében, vagyis hogy máshogyan kell-e kezelni a felzárkózó, mint a lemaradó országokat!

Hogy ennek a relatív tulajdonjog-védelmi erősségnek, vagy változásának hatását meg tudjuk vizsgálni a modellben, térjünk vissza a (4) egyenlethez! Átírva az egyenletet, az alábbi összefüggés adódik:

$$
\alpha_{e}=1+\frac{\frac{\Pi_{i}-F C}{\Pi_{i}}-1}{1-G \cdot \alpha_{i}}
$$

Ha lerögzítjük a profithányadot, akkor meg tudjuk nézni, hogy különböző $G$ értékek mellett mely $\alpha_{i}$ és $\alpha_{e}$ értékekre teljesül az egyenlet. Ekkor az $\alpha_{i}$ ( $x$ tengely) és $\alpha_{e}$ (y tengely) terében az adott П-hányadhoz tartozó szintvonalakat kapunk (4.4. ábra).

\footnotetext{
${ }^{51}$ Képezhetnénk akár egy harmadik csoportot is. Ebbe azok a fejlődő országok kerülnének, akik nem csak, hogy jobban szigorítják IPR védelmüket, mint fejlett kereskedelmi partnerük, de végül még egy náluk is szigorúbb szabályozás lesz az eredmény: $0<\omega_{0}<1<\omega_{1}$. Ezek az országok a beelözők.
} 
4.4. ábra. Az importőr és az exportőr IPR-védelmi erősségének hatásai

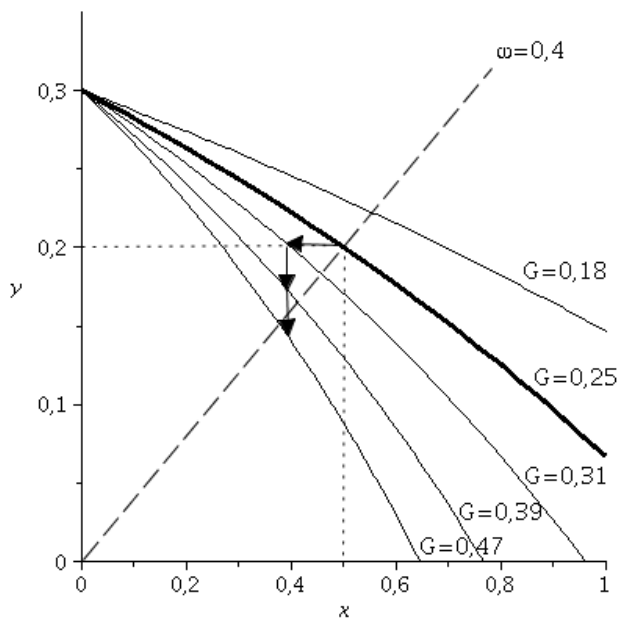

Forrás: saját szerkesztés

Az ábrán az origótól távolodva egyre kisebb $G$ értékek mellett teljesül (4).

Vegyünk az előző pontban említett paraméterértékeket, vagyis 0,3-as П-hányad mellett legyen $\alpha_{i}=0,5$ és $\alpha_{e}=0,2$, amit az ábrán be is jelöltem kiindulópontként. Az ábrán a kezdeti $\left(\alpha_{i} ; \alpha_{e}\right)$ kombinációt szaggatott vonallal összekötöttem az origóval. Ezen egyenes mentén a déli relatív szabadalmi védelmi erősség változatlan, $\omega=\frac{\alpha_{i}}{\alpha_{e}}=\frac{0,2}{0,5}=0,4$. Az egyenes alatt a déli relatív szabadalmi védelem romlik, míg az egyenes fölötti kombinációk a déli relatív szabadalmi védelem javulását jelzik.

Az ábra azt mutatja, hogy bármely tengely mentén mozdulunk az origó irányába, rögzített П-hányadot egyre nagyobb $G$ mellett érünk el (ahogyan azt a 4.3. ábrán is láthatjuk). A déli IPR védelem szigorodása a kiidnulópontból a vízszintes tengely mentén mozdít el, és ceteris paribus növeli $G^{*}$ értékét (jelen példában 0,25-ről 0,31-re). Az északi védelem szigorodása szintén növeli ezt. Ha az északi védelem szigorodása kisebb mértékü a délinél, akkor a déli védelem relatív erőssége nő: a déli ország felzárkózik. Ha az észak védelem szigorodása azonban nagyobb mértékü, akkor a relatív déli védelem relatív erőssége csökken: a déli ország lemarad.

A modell azt mutatja, hogy a déli ország szabadalmi védelmi szabályozásának adott mértékủ szigorítása mellett a relatív védelmi erősség változása $G^{*}$ változásának irányát nem, csak nagyságát befolyásolja. Rögzített nagyságú déli szigorodás mellett a relatív erősödés kisebb mértékben növeli $G^{*}$ értékét, mint a relatív lemaradás. 


\subsubsection{Az IPR szigorodásának iparáganként eltérő hatása}

Az IPR védelem szigorítása bár $G^{*}$ értékét egyértelműen növeli, nem egyforma mértékben érinti azonban a high tech és a low tech termékeket. Mint bemutattam, az IPR védelem szigorodásával a határon lévő bonyolultság $\left(z^{*}\right)$ egy magasabb $G$ mellett áll elő. Mivel azonban a modellfeltevés szerint $G(H)$ konvex, $G(L)$ pedig konkáv, így alacsony $G$ esetben $G$ növekedése jobban növeli a high tech, mint a low tech termékek körét, míg kellően magas $G$-k esetében pedig a low tech termékek köre jobban növekszik, mint a high tech termékeké. Meghatározhatjuk azt a $G$ értéket, melytől lefelé $G$ növekedése a high tech termékek körét jobban növeli, mint a low tech termékekét. A

$\frac{\partial z}{\partial G(H)}=\frac{\partial z}{\partial G(L)}$ egyenletet megoldva az alábbi $\hat{G}$ határértéket kapjuk:

$$
\hat{\mathrm{G}}=\left(\frac{\mathrm{r}_{\mathrm{L}}}{\mathrm{r}_{\mathrm{H}}}\right)^{\frac{\mathrm{r}_{\mathrm{H}} \cdot \mathrm{r}_{\mathrm{L}}}{\mathrm{r}_{\mathrm{H}}-\mathrm{r}_{\mathrm{L}}}} .
$$

Az alábbi táblázat mutatja a kritikus $\hat{G}$ értéket különböző $r_{L}$ (oszlopokban) és $r_{H}$ (sorokban) értékek mellett.

4.1. táblázat. A kritikus $\hat{G}$ értéke különböző $\mathrm{r}_{\mathrm{H}}$ és $\mathrm{r}_{\mathrm{L}}$ mellett

\begin{tabular}{|r|rrrrrrrr|}
\hline $\mathrm{rH} \backslash \mathrm{rL}$ & 0,001 & 0,01 & 0,05 & 0,1 & 0,2 & 0,5 & 0,75 & 0,99 \\
\hline 1,001 & 0,993 & 0,955 & 0,854 & 0,774 & 0,669 & 0,500 & 0,422 & 0,370 \\
1,01 & 0,993 & 0,954 & 0,854 & 0,774 & 0,668 & 0,498 & 0,420 & 0,368 \\
1,5 & 0,993 & 0,951 & 0,839 & 0,748 & 0,628 & 0,439 & 0,354 & 0,298 \\
2 & 0,992 & 0,948 & 0,828 & 0,730 & 0,599 & 0,397 & 0,308 & 0,252 \\
5 & 0,992 & 0,940 & 0,792 & 0,671 & 0,511 & 0,278 & 0,188 & 0,135 \\
10 & 0,991 & 0,933 & 0,766 & 0,628 & 0,450 & 0,207 & 0,122 & 0,079 \\
\hline
\end{tabular}

Forrás: saját számítások

A fenti táblázatnak megfelelően akár a 4.2, akár a 4.3 ábrába bejelölhetjük $\hat{G}$ értékét, a függőleges tengellyel párhuzamosan, hiszen az imitáció valószínűségétől független. Amennyiben $G^{*}<\hat{G}$, akkor a szabadalmi rendszerek szigorúságában bekövetkező változás erőteljesebben fogja érinteni a high tech, mint a low tech termékeket. Minden egyéb változatlansága mellett tehát egy felzárkózó országban inkább a high tech, míg egy lemaradó országban inkább a low tech termékek körének bővülését jelzi előre a modell.

Ahogyan a vállalható imitációs határkockázat nő, érdemes lesz egyre kevésbé bonyolult, vagyis egyre könnyebben lemásolható termékekkel is megjelenni a külpiacon. Az immár expotálásra érdemes csökkenő bonyolultságú termékek között eleinte még több high tech, mint low tech termék lesz. Ahogyan folyamatosan csökkentjük a bonyolultságot, 
egyre kevesebb új high tech, de egyre több új low tech termék kerül be azok közé, melyeket exportálni érdemes.

Valójában az $r_{H}$ és $r_{L}$ értékeinek változtatásával a déli ország abszorptív kapacitásán változtatunk, vagyis azon, hogy mennyire képesek egy adott bonyolultságú terméket lemásolni. Az $r$ értékei a déli ország technikai színvonalától függnek: minél fejlettebb a déli ország, annál alacsonyabb értékeket vesznek fel az $r$-ek. Az alábbi, 4.5. ábrán két különböző másolási képességű déli országot ábrázoltam, szaggatott vonallal jelöltem egy az imitációban kevésbé ügyes országot (gyenge imitatív képesség, ld. Smith 1999), míg folytonos vonallal egy ügyesebb országot.

4.5. ábra. Országok abszorptív kapacitásai közti különbségek a modellben

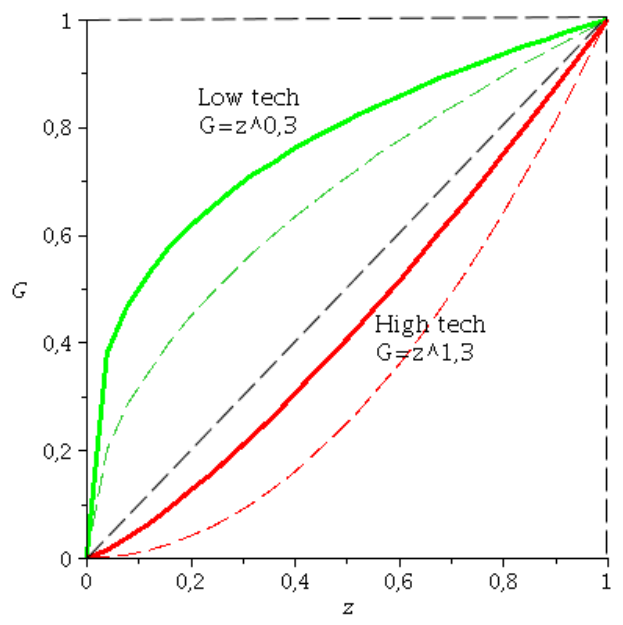

Forrás: saját szerkesztés

A 4.1 táblázat szerint $\hat{G}$ magasabban van a nagyobb imitatív képességű országok esetében. Ha megvizsgáljuk, $G^{*}$ emelkedése az ábrán mit eredményezne, akkor azt találjuk, hogy mindkét féle országba növelné mindkét féle termékböl a kereskedésre érdemes termékek körét. Ugyanakkor a kevésbé hatékonyan másoló országokba azonos $G^{*}$ mellett jobban megéri exportálni a termékeket. Ahogyan $G^{*}$ emelkedik, alacsony értékei mellett a növekedés jobban ösztönzi az északi vállalatot high tech termékkínálatának bővítésére, magasabb értékek mellett pedig a low tech termékek exportjára.

A felzárkózás-lemaradás hatása a különböző iparágakban tehát attól is függhet, hogy a kérdéses fejlődő ország milyen imitatív képességekkel rendelkezik. Mint láttuk, egy lemaradó ország esetében $G^{*}$ jobban növekszik, mint egy felzárkózó esetében. Tegyük fel, hogy a lemaradó ország egyben ügyesebb imitáló is, a felzárkózó pedig gyenge imitáló, tehát $\hat{G}$ alacsonyabb a lemaradó országban, mint a felzárkózóban. Ebben a speciális helyzetben a lemaradó országban fog nagyobb mértékben nőni a high tech 
termékbehozatal. Ha azonban a felzárkózás nagyobb imitációs képességgel párosul, akkor ez a két tényező erősíti egymást a high tech termékimport bevonzásában.

Hasonlóan, a felzárkózás-lemaradás hatását befolyásolhatja az exportálással elérhető, a modell szerint országoktól, iparágaktól és bonyolultságtól független profithányad is. Minél magasabb a profithányad, annál valószínübb, hogy $G^{*}>\hat{G}$. Azaz, ha importőr országonként különböző lehet a profithányad, akkor elképzelhető, hogy a felzárkózók esetében a profithányad rendkívül magas, míg a lemaradók esetében pedig alacsony. Ekkor is előfordulhatna, hogy a felzárkózó országban bővül nagyobb mértékben a low tech termékek köre.

A fent bemutatott modell rendkívül egyszerü következtetésre vezetett. Először is azt mutatja, hogy a szellemi tulajdon jogvédelem megváltoztatásának (szigorításának) hatása egy fejlődő országra más lesz annak függvényében, hogy kereskedelmi partnerénél eközben hogyan változik a szellemi tulajdonjog-védelmi erősség. Adottnak tekintve a déli országban érvényes IPR szigorodásának mértékét, a modell azt mutatta eredményül, hogy a fejlett országból a fejlődő ország felé áramló termékek köre más ütemben bővül a fejlett országban érvényes IPR-védelem szigorodásának mértékétől függően.

A modell elörejezése szerint bármely országban következzék is be a szabadalmi védelmi rendszer szigorítása, az mindenképpen csökkenti annak a kockázatát, hogy valamely versenytárs egy imitatív termékkel jelenjen meg, és ezáltal az eredeti innovátor egyeduralmát megtörve a monopolprofitját eltűntesse. A déli országban bekövetkező szigorítás adott mértéke mellett az egyidejü északi szigorítás minél nagyobb, az annál jobban növeli az északi exportőrök által viselhető imitációs határkockázatot. Ha az északi szigorodás mértéke kisebb, mint a délié, akkor a déli védelem végső soron relatíve erősödik, a déli ország felzárkózik. Ha azonban az északi szigorodás nagyobb mértékü, akkor a déli országban érvényes szabadalmi védelelem relatíve gyengül, a déli ország lemarad. Az imitációs határkockázat növekedése tehát a lemaradó országok esetében nagyobb, mint a felzárkózó országok esetében.

A déli szabályozás relatív erősödése vagy gyengülése tehát a délre irányuló export válozásának irányát nem befolyásolja, csak a mértékét. Ha azonban azt feltételezzük, hogy a termékek lemásolhatósága máshogyan függ a bonyolultságuktól a high-tech mint a lowtech termékek esetében, akkor az imitációs határkockázat emelkedése másmilyen hatást gyakorol a high- és a low- tech termékek volumenére a lemaradó és a felzárkózó déli országok esetében.

A következő fejezetben empirikusan vizsgálom meg, hogy fedezhetö-e fel összefüggés egy fejlődő importőr ország relatív IPR-védelmi erősségének változása, és annak hatása között a high-, illetve low tech termékimportjára fejlett kereskedelmi partnerétöl. 


\section{A relatív szabadalmi védelmi erősség változás hatása a termékáramlásra}

Az előző fejezetben modell-szintủ elemzésben mutattam meg a TRIPS megállapodások, és általában véve a szellemi tulajdonjog-védelmi szabályozás relatív erősítésének hatásait. Ahogyan látszódott is, a 90-es évek elején az elméleti irodalom egyértelmủen azon az állásponton volt, hogy a fejlődő országok (az észak-déli kereskedelmi modellek déli országai, ahol innováció nem történik) egyértelműen rosszul járnak, ha fokozottan védik a szellemi tulajdont. A fejlődő országok érvelése az IPR védelem szigorítása ellen az volt, hogy amennyiben szigorúan védik az innovátor országok szellemi tulajdonjogait, akkor azok behozzák ugyan innovatív termékeiket a fejlődő országba, viszont túlzottan magas monopol áron fogják csak értékesíteni azokat. A fejlődő országok alacsonyabb imitációs képessége miatt a piacierő-hatás fog dominálni (Maskus - Penubarti, 1995), a magas áron viszont az egyébként is alacsony jövedelmű fejlődő országokban viszont csak kevesen fognak tudni hozzájutni a már egyébként is előállt tudást megtestesítő termékhez. Ez az érvelés különösen a szabadalmi védelemre amúgy is erősen támaszkodó gyógyszeripar esetében kapott erős hangsúlyt. Az ezredfordulóra azonban az elméleti irodalomban is kezdtek olyan modellek megjelenni, melyekben megfelelő peremfeltételek mellett az erősödő déli IPR védelem előnyökkel járhatott a fejlődő országok számára is.

Az előző fejezetben ezen elméleti irodalmi háttérre támaszkodva igyekeztem bemutatni, hogy a fejlődő országok IPR védelmének relatív erősödése vagy gyengülése milyen hatással lehet a fejlett és fejlődő országok közötti kereskedelemre. A TRIP megállapodások megkötésével sok kutató empirikusan is górcső alá vette az erősödő fejlődő országbeli IPR védelem hatását a nemzetközi tudásáramlásra (akár termékek, akár direktberuházások, vegyes vállalatok vagy licencszerződések által). Az empirikus eredmények sem teljesen egyértelmüek a tekintetben, hogy a fejlődő országok az IPR védelmi rendszerük erösítésével vajon jobban, vagy éppen kevésbé juthatnak hozzá fejlett technológiákhoz, általánosabban fogalmazva tudáshoz. Az eltérő eredmények, ahogyan az irodalmi áttekintésben bemutatom, származhatnak az eltérő vizsgálati módszerekből, eltérő csoportosításokból vagy nem azonos fogalomhasználatból. Ebben a fejezetben a korábbi empirikus vizsgálatokra építve építem be ismét a relatív IPR védelem erősségét, illetve 
annak változását, mint magyarázó változót, a nemzetközi tudásáramlás (illetve annak megfelelően leszükítendő szegmense) magyarázására. Az előző fejezetben bemutatott modellem eredményeiből azt a feltételezést teszem, hogy a fejlett országok szellemi tulajdonjogi védelmi rendszerének erősödése nagyobb hatással van a high-thech termékimportjukra, hogyha (a kereskedelmi partnereikhez képest értelmezett) relatív erősödéssel párosul - ezek a korábban említett felzárkózó országok -, mint ha relatív gyengüléssel ezek a fentebb említett lemaradó országok. Statisztikai módszerekkel vizsgálom tehát meg, hogy az IPR védelem tekintetében felzárkózó fejlődő országok valóban több high-tech termékhez jutnak-e a fejlett kereskedelmi partnereiktől, mint a lemaradók.

Az első alfejezet irodalmi áttekintést ad a szellemi tulajdonjog-védelmi rendszer erőssége és a nemzetközi kereskedelem eddigi empirikus eredményeiről. A második alfejezetben hármas problémakörben mutatom be a saját empirikus vizsgálatom elméleti hátterét: először is megvizsgálom, hogyan mérhető (immár nem modell-szinten, hanem a valóságban) az egyes országokban érvényes IPR védelmi rendszer erőssége. Másodszor lehatárolom azt a mutatót, melynek segítségével az empirikus vizsgálatban a tudásterjedést mérni fogom. Harmadszor pedig ismertetem az alkalmazott statisztikai módszert és annak elméleti hátterét. A harmadik alfejezetben azt mutatom be, hogy az elemzéshez milyen adatokat használtam fel, és azok honnan származnak. A negyedik alfejezetben bemutatom empirikus vizsgálatom eredményeit. Végül az ötödik részben összefoglalom a kutatás korlátait, és további lehetséges kutatási irányokat vetek fel.

\subsection{Irodalmi áttekintés}

A szellemi tulajdonjog-védelem hatását az áruk és szolgáltatások nemzetközi forgalmára empirikus módon is vizsgálták. A különböző módokon, különböző időpontokban elvégzett vizsgálatok, akárcsak az elméleti irodalom, nem jutottak egyértelmü következtetésre az IPR védelem erősség szigorodásának a nemzetközi termékforgalomra gyakorolt hatását illetően. Az empirikus irodalom e szempontból tehát négy nagyobb részre osztható: amely kutatások nem találtak szignifikáns kapcsolatot, amelyek szignifikáns pozitív kapcsolatot, amelyek szignifikáns de negatív kapcsolatot illetve amelyek vegyek kapcsolatot találtak az IPR változás és nemzetközi termékáramlás között. 


\section{Nincs szignifikáns kapcsolat az IPR változás és a kereskedelem közt}

A legkorábban említendő ilyen vizsgálat Ferrantino (1993) cikkéhez kötődik, aki nem talált szignifikáns kapcsolatot az IPR védelem erőssége és a nemzetközi termékáramlás között. Empirikus vizsgálatának a témakörben később irányadó szerzők által leginkább kritizált hiányossága az volt, hogy egyrészt a termékáramlást nem vizsgálta szektorális bontásban, így nem derülhetett ki, hogy egyes szektorok valójában reagálhatnak az IPR védelem erősségére. Másrészt a szellemi tulajdonjog-védelem erősségének is egy kezdetleges formáját használta.

\section{Pozitív kapcsolat az IPR erősödés és a termékimport közt}

Ezeket a hibákat küszöbölte ki az IPR erősség és nemzetközi kereskedelem összefüggésének empirikus irodalmában írt leggyakrabban idézett Maskus és Penubarti nevéhez füződő 1995-ös vizsgálat. A szerzők azt találták, hogy lineáris regressziós modelljükben az effektív szabadalmi védelem erősségét mutató index regressziós együtthatója az országok közötti termékáramlásra pozitív és erősen szignifikáns. Ebből arra következtettek, hogy „minden országra és minden iparágra nézve az effektív szabadalmi védelem erősítése átlagosan növeli a bilaterális importot” (Maskus - Penubarti 1995, 241.o.). Jelentős különbséget találtak ugyanakkor a kisebb és a nagyobb fejlődő importőr országokra gyakorolt hatás között: az erősebb szabadalmi védelemnek nagyobb volt a hatása a nagy importőr országok esetében, mint a kisebbek esetében. A szektoronkénti bontás pedig az egyes szektorokra gyakorolt hatás között mutat különbséget: a „szabadalmakra a-priori kevésbé érzékeny” (Maskus - Penubarti 1995, 238. o.) iparágakban (pl. vas- és acélipar, bőráruk, italok) erősebben növeli az importot a szabadalmi védelem erősödése, mint a „magas a-priori szabadalom-érzékenységűekben” (pl. elektronikus berendezések, műanyagáruk, gyógyszerek). Mind az országok közti, mind a szektorok közti különbséget a szerzők a már korábban említett piacierő-hatás és a piackiterjesztő hatás együttes eredményeként magyarázzák: a szabadalmakra erőteljesebben építő iparágakban az imitáció veszélye kisebb, ezért a piacierő-hatás dominál, nagyobb országok esetében pedig a nagyobb kereslet miatt a piackiterjesztő hatás érvényesül erőteljesebben.

Park és Lippoldt (2008) szintén egy lineáris regressziós modellben vizsgálták az IPR védelem erősségének a hatását a technológiatranszferre, a direktberuházásokon illetve a termék- és szolgáltatás-importon keresztül. Modelljükben pozitív, statisztikailag szignifikáns kapcsolatot találtak az IPR védelem erőssége és az összes termékimport között 
az összes vizsgált országot tekintve. A regressziós együttható nagyobb pozitív értéket vesz fel a fejlett országok esetében. A fejlődő és legkevésbé fejlett országok esetében szintén pozitív ugyan az IPR védelem erősségének együtthatója, de egyre kisebb az értéke és a szignifikanciája. A szektorális bontásból azt találták a szerzők, hogy a technológia-intenzív (Park - Lippoldt 2008, 19. o.) iparágakban (gyógyszerek és vegyszerek, irodai készülékek, elektronikai és precíziós berendezések) a fejlődő országokba az IPR védelem pozitív hatása az importra az átlagosnál erösebben érvényesül.

Ivus (2010) empirikus vizsgálatában fejlett országok fejlődő országokba irányuló termékexportjának időbeli alakulását vizsgálta szabadalom-érzékeny és nem szabadalomérzékeny iparágakban a fejlődő országok IPR védelmének erőssége függvényében. Azt találta, hogy az IPR védelem erősítése a fejlődő országokban növeli a fejlett országok szabadalom-érzékeny termékexportját ezekbe, méghozzá nagyobb mértékben, mint a nem szabadalom-érzékeny termékek exportját.

\section{Negatív kapcsolat az IPR erősödés és az import közt}

Smith (1999) vizsgálatában a fentiekkel ellentétben negatív, statisztikailag szignifikáns kapcsolatot talált a szellemi tulajdonjog-védelem erőssége és a fejlődő országokba irányuló termékimport között. Ez tehát azt jelenti, hogy az országcsoporton belül a szigorúbb IPR védelemmel rendelkező országok kevesebb teremék-importot vonzanak be. Ez a kapcsolat mind a magas, a közepesen magas és az alacsony jövedelmü országokban fennállt, pozitív kapcsolat csak a közepesen alacsony jövedelmü országok esetében látszik. A negatív kapcsolatot a Maskus - Penubarti (1995) szerzőpáros által is feltárt piacierő-hatás és piackiterjesztő hatás segítségével magyarázza: a negatív kapcsolat a piacierő-hatás dominanciáját jelzi, míg a pozitív pedig a piackiterjesztő hatásét. Smith azonban explicit módon figyelembe veszi az országok imitációs képességét, ${ }^{52}$ és azt találja, hogy a gyenge imitációs képesség a piacierő-hatással társul, és negatív regressziós együtthatót eredményez az IPR védelem erősségének hatására, míg a nagy imitációs veszély esetén a piackiterjesztő hatás érvényesül, és az IPR védelmem erősségének regressziós együtthatója pozitív. Az a-priori szabadalom-érzékeny iparágak tekintetében az IPR védelem erősségének hatása erőteljesebb, mint az összes iparág aggregátumának esetében (vagyis, ha eleve a piacierő-hatás dominál, akkor kisebb negatív, ha eleve a piackiterjesztő hatás, akkor nagyobb pozitív regressziós együtthatót kap eredményül).

\footnotetext{
${ }^{52} \mathrm{Az}$ imitációs képesség erősségének mérésére olyan mutatókat használ, mint a kutatás fejlesztésben részt vevők száma 10000 lakosra vetítve, vagy a GNP-arányos kutatás fejlesztési kiadások.
} 
Co (2004) vizsgálatának eredményéül azt állapítja meg, hogy az IPR védelem időbeli változása önmagában nincs hatással a termékáramlásra, csak az imitatív képesség változásának figyelembe vételével együtt. A K+F intenzív iparágak esetében negatív, de nem szignifikáns hatása van az IPR védelem erösödésének a termékforgalomra, a nem $\mathrm{K}+\mathrm{F}$ intenzív iparágak esetében pedig negatív és szignifikáns hatása. A szabadalmi védelem erösödése javítja az importőr ország imitatív kapacitását, ami viszont visszafogja az oda érkező importot. Az imitatív képességnek lehet azonban egy olyan szintje, amely mellett a szabadalmi védelem erősödése már növeli a termékbehozatalt (akárcsak Smith (1999) esetében).

\section{Vegyes eredmények}

Fink és Primo Braga (1999) eredményei vegyes képet mutatnak. Az IPR védelem erősödésének pozitív és szignifikáns hatását találták az összes nem üzemanyag jellegü termék importjára, a high-tech iparágak esetében azonban a hatás enyhén negatív, de nem szignifikáns. Magyarázatul részben ők is a piacierő-hatást említik, ami a high-tech iparágak esetében túlkompenzálhatja a piackiterjesztő hatást, másrészt pedig a külpiac kiszolgálásának más alternatív lehetőségeit (például direktberuházásokon keresztül), amelyek ezen iparág esetében dominálhatnak. Tanulmányuk érdekessége, hogy exportot és importot egyaránt vizsgálnak, de befolyásoló tényezőként mindig csak az importáló ország IPR védelmi erősségét használják a statisztikai modelljükben: „az IPR-nek a termékforgalmat bevonzó szerepére vagyunk kíváncsiak, és nem pedig a termékforgalmat generáló szerepére" (Fink - Primo Braga 1999, 8. o.).

Összefoglalva azt láthatjuk, hogy az empirikus irodalom is föleg a fejlődő országok abszolút IPR-védelmének kereskedelemre, termékimportra gyakorolt hatását vizsgálja, de a kutatások eredményei nem egyértelmüek, akárcsak az elmélet előrejelzései. Amint a fenti áttekintésből kiderül, az empirikus vizsgálatok egy része az IPR védelem erőssége és a termékáramlás között nem mutatott ki szignifikáns kapcsolatot (Ferrantino 1993), míg mások pozitív (Maskus - Penubarti 1995, Park - Lippoldt 2008, Ivus 2010), vagy éppen negatív kapcsolatot találtak (Smith 1999). Felderítetlen terület azonban az a kérdés, hogy a kereskedelmi partnerek közötti relatív IPR-védelem megváltozása hogyan befolyásolja a termékek és szolgáltatások nemzetközi áramlását. 


\subsection{Vizsgálati kérdés és módszer}

A disszertációm ezen utolsó részében a célom, hogy megvizsgáljam egy fejlett exportáló és egy fejlődő importáló ország viszonyában, hogy egy fejlődő ország szellemi tulajdonjog védelmének alakulása nem önmagában véve, hanem a kereskedelmi partneréhez képest értékelve hogyan befolyásolja a tudás-intenzív termékek exportját a fejlődő országba.

Az előző fejezet modelljét empirikusan vizsgálva bármely két, egymással kereskedelmi kapcsolatban álló fejlett, északi, innovátor $A$ ország és fejlődő, déli, imitátor $B$ ország esetében megállapítható, hogy szellemi tulajdonjog-védelmi szabályozásuk abszolút értelemben véve külön-külön szigorodott vagy enyhült-e, illetve ezek alapján hogyan változott kettőjük között a relatív IPR védelem erőssége. Az előző fejezet modellje alapján megfogalmazott hipotéziseim, melyeket jelen fejezetben tesztelni kívánok, a következők:

Hipotézis 1: A relatív szellemi tulajdonjog-védelmi erősség változása alapján definiált felzárkózó és lemaradó országokban nem egyforma mértékben változik az import a tudás-érzékeny és a nem tudás-érzékeny termékek esetében.

Hipotézis 2: A felzárkózó országok esetében nagyobb mértékü tudásintenziv termékimport-növekedés figyelhetö meg, mint nem tudás-intenzív, a lemaradó országokhoz képest.

Ennek vizsgálatához három dolgot szükséges specifikálni: először is, miként mérhető az egyes országokban a szellemi tulajdonjog-védelem erőssége, illetve hogyan operacionalizálható a fejlődő ország felzárkózása vagy lemaradása fejlett kereskedelmi partneréhez képest. Másodsorban szükséges mérni a tudástranszfer nagyságát is a két ország között. Harmadrészt az összefüggések vizsgálatához szükséges egy statisztikailag megalapozott módszer. 


\subsubsection{A szellemi tulajdonjog-védelem erősségének mérése}

A téma korai vizsgálatánál Ferrantino (1993) a szellemi tulajdonjogi védelmi rendszer erősségét az alapján mérte mindössze, hogy az adott ország milyen nemzetközi szellemi tulajdonjog-védő egyezményekben vesz részt: minél több ilyen egyezmény aláirója az adott ország, a védelem ott annál erősebbnek tekinthető.

$\mathrm{Az}$ egyes országok a nemzeti szellemi tulajdonjog-védelmi rezsimen belül a különbözőféle szellemi tulajdont különbözöképpen és különböző erősséggel védhetik. A szellemi tulajdonon belül beszélhetünk szabadalmakról, szerzői jogokról, védjegyekröl, eredetmegjelölés-oltalomról vagy üzleti titokról. A későbbiekben a szakirodalom nem a szellemi tulajdonjog-védelmi intézményrendszer, mint komplex egész erősségét, szigorúságát méri, hanem különválasztja annak egyes részeit. Dolgozatomban, ahogyan eddig is a szabadalmakkal foglalkoztam, a továbbiakban is csak a szabadalmi rendszerrel, és a szabadalmi védelem erősségével, ennek mérésével és hatásaival kívánok foglalkozni. ${ }^{53}$

A szabadalmi védelem erősségének, szigorúságának mérésére is többfajta módszert alkalmaznak. A legkorábban kidolgozott ilyen mutatószám a Rapp-Rozek Index (Rapp Rozek 1990). Ez az index az egyes nemzeti szabadalmi szabályok megfelelésének mértékét adja meg az Egyesült Állami Kereskedelmi Kamarájának ajánlásaihoz, olyan dimenziók mentén, mint a szabadalmaztatható újitások köre, a védelem idötartama, jogok átruházhatósága, kötelező licencbe adás szabályai és a szabadalmi jogsértés elleni effektív védelem. Az index az egyes nemzeti szabályok 1984-es állapotát méri fel, és minden dimenzió esetében 1-es értéket ad a megfelelés és 0-t a nem megfelelés esetén, így az index 0-5 közti intervallumban vesz fel egész értékeket. Ezt az indexet használja például ökonometriai modelljében (egyik) magyarázó változóként Maskus és Penubarti (1995).

Ginarte és Park (1997) egy másik fajta indexet dolgoz ki. A Ginarte-Park index, más néven a szabadalmi jogi index (Index of Patent Rights) szintén öt dimenzió mentén mér: mikre terjedhet ki a szabadalmi védelem, milyen nemzetközi egyezményeknek tagja az adott ország, milyen esetekben veszíthető el a védelem, milyen időre szól a védelem és milyen szabályai vannak a végrehajtatásnak. Az öt dimenzió további al-dimenziókra oszlik, minden dimenzió értéke 0 és 1 közé esik, a végső indexérték pedig ezek súlyozatlan összege. ${ }^{54}$ Smith (1999) erős pozitív korrelációt mutat ki a Rapp-Rozek és a Ginarte-Park

\footnotetext{
${ }^{53}$ A szabadalmakon kívül a szellemi tulajdonjogok más területeinek védelmi erősségét is lehet mérni, ezekre is kidolgoztak indexszámokat. A később bemutatandó szabadalmi védelmi index mellett számítható szerzői jogvédelmi index, védjegy védelmi index is. Ezen indexek mind országonként pozitívan korrelálnak egymással (Park - Lippoldt 2008).

${ }^{54} \mathrm{Az}$ index összetételét részletesebben lásd a 2. mellékletben.
} 
mutató között, a szakirodalom azonban szívesebben alkalmazza a Ginarte-Park indexet, mivel ennek az indexnek az értéke öt éves periódusonként, tehát több időpontra is ismert 1960-tól kezdődően, és folytonos változóként inkább kezelhető. ${ }^{55}$ Ezt a mutatószámot használja az egyes országok IPR védelmi erősségének mérésére ökonometriai modelljében például Park és Lippoldt (2008) vagy Ivus (2010) is.

Ezen két mutató közös hátránya, hogy csupán a törvény betüjét veszik figyelembe, a törvények betartásának szigorúságát nem. A nagyobb tulajdonjogi biztonság szempontjából az innovátor vállalatok ugyanis nem csak azt veszik figyelembe, hogy milyen szabályozás van életben, melyet be lehet tartatni, hanem annak a valószínüségét is, hogy azokat valóban be is fogják tartatni (Czeglédi 2009). A szabályok megléte és hatékonysága problémáját Hu és Png (2009) úgy oldják meg, hogy kombinálják a GinartePark indexet a Fraser Intézet által összeállított indexszel, amely az egyes országok jogrendszerét és tulajdonjogi szabályait értékeli. Az általuk javasolt effektív szabadalmi index a Ginarte-Park index és a Fraser index szorzata. Egy másik lehetséges módszer az empirikus vizsgálatoknál valamilyen kontrolváltozó beépítése a törvények betartatásának mérésére (például a Fraser index beépítése (Zuniga - Aboites 2003), vagy a World Economic Forum által végzett felmérés adataié, ahol vállalati felsővezetőket kérdeztek az IPR védelem általuk észlelt erősségéről (Park - Lippoldt 2008)).

Az empirikus vizsgálatom során a relatív IPR védelem erősségének kiszámítására és változásának mérésére én is a szakirodalomban leggyakrabban használt Ginarte-Park indexet fogom alkalmazni.

\subsubsection{A tudásáramlás mérése}

A tudástranszfer számos fentebb említett dimenziója közül jelen fejezetben a termékek nemzetközi kereskedelme csatornáját fogom vizsgálni, mint ahogyan ezt a leszükítést már az előző fejezet modelljében is megtettem. A vizsgálatom tárgya a fejlett országokból a fejlődő országokba áramló termékexport alakulása.

A termékexporton belül is feltételezhető azonban, hogy a szabadalmi védelem szabályainak megváltozása az importáló országban nem egyformán érint minden iparágat. Ez az iparáganként eltérő hatás a TRIPS-vitában már a kiindulástól kezdve ismert és vizsgált körülmény (Maskus - Penubarti 1995, Smith 1999, Ivus 2010). Nincs azonban

\footnotetext{
${ }^{55}$ A Ginarte-Park index valódi folytonos változónak nem tekinthető, mert nem vehet fel tetszőleges értéket a 0-5 intervallumon. Mivel azonban felvehet bizonyos nem egész értékeket is, az empirikus szakirodalom mégis mindig folytonosként kezeli.
} 
egyetértés a tekintetben, hogy mely iparágakat tekintsük a szabadalmi védelmi szabályozással jobban, illetve kevésbé összefüggőnek. Még az iparág-csoportok megnevezésében is nagy a heterogenitás: vizsgálnak szabadalom-intenzív, K+F-intenzív, szabadalom-érzékeny, és tudás-intenzív iparágakat.

Maskus és Penubarti (1995) az általuk vizsgált 28 iparágat három csoportra osztják: a priori leginkább szabadalom-érzékeny, a priori legkevésbé szabadalom-érzékeny és egyéb iparágak. Az első csoportba tartozónak olyan iparágakat tekintenek, ahol az USA-beli kutatás-fejlesztés a legnagyobb mértékben függ attól, hogy kaphatnak-e az előálló eredményért amerikai szabadalmat, illetve amely iparágak képviselői a felmérésekben leginkább úgy nyilatkoznak, hogy jelentős veszteségeik vannak a külföldön érvényesülő korlátozottabb szabadalmi védelemből (241. o.). A leginkább szabadalom-érzékeny iparágak közé ezek alapján olyanokat sorolnak, mint az elektromos berendezéseket, műanyag termékeket vagy élelmiszert előállító iparágak. Hasonló módszert követ Smith (1999) is.

Cohen et al. (2000) 34 iparágban vizsgálta meg kérdőívek segítségével, hogy mely mechanizmus (köztük a szabadalom, az üzleti titok vagy a lead time) a leghatásosabb az egyes iparágakban tevékenykedő vállalatok számára az újítások védelmében. Termékinnováció esetén például a szabadalmakat a legfontosabbnak az orvosi berendezéseket gyártó iparágban valamint a gyógyszeriparban ítélték. Ivus (2010) erre a kutatásra épít, amikor szabadalom-érzékeny és nem szabadalom-érzékeny iparágakat különböztet meg. Nála Cohen et al. (2000) alapján olyan iparágak kerülnek a szabadalom-érzékenyek közé, mint például az ipari vegyszerek és az egyéb vegyszerek.

Yang (2006) egy szabadalom-intenzitási mutatót számol az egyes iparágakra, mégpedig az elnyert szabadalmak és az árbevétel hányadosaként (18. o.). Ebben a csoportosításban a leginkább szabadalom-intenzív iparágak az ipari gépeket, berendezéseket, illetve az elektronikus berendezéseket előállító iparágak.

A United Nations Industrial Development Organization (UNIDO) Industrial Development Reportjaiban háromféle iparág-kategóriát különböztet meg: Low Technology, Medium Technology és High Technology iparágakat. A kiadvány rendszeresen jelenik meg, a legkorábbi elérhető változata 2002/2003, a legfrissebb pedig 2011-es kiadású. Az iparágak csoportosítását az SITC (Standard International Trade Classification) szerinti bontásban adja meg a kiadvány, eredetileg az SITC Rev. 2. nomenklatúra szerint, majd 2009-től kezdődően már a Rev. 3. szerint. Jelen kutatásomban az UNIDO (2002) csoportosítást veszem alapul mivel az általam vizsgált időszakban 
(1995-2005) ez a csoportosítás a releváns (a 2004 és 2005-ös kiadványok is ugyanezt alkalmazzák), számottevő változtatás csak később következett be. A 3. melléklet tartalmazza, hogy az alkalmazott csoportosítás szerint mely iparágak tartoznak a High, Medium és Low Technology iparágak közé.

\subsubsection{Vizsgálati módszer}

Harmadik fontos kérdés, hogy empirikusan milyen módszerrel vizsgálható a nemzetközi termékáramlás. Empirikus vizsgálatokban gyakorta alkalmazott eszköz a gravitációs modell. Ebben a modellben az országok közötti termékáramlást főleg az országok mérete és egymástól való távolsága határozza meg, de az elméleti megalapozottsága nem teljesen egyértelmü (Feenstra et al. 2001). Ezzel a nemzetközi kereskedelem empirikus vizsgálatára alkalmazott gravitációs modellel hozta össze Bergstrand (1989) az elméletben alkalmazott magyarázó modelleket. Bemutatja, hogy a gravitációs modellben egyaránt kezelhető a Hekscher-Ohlin modellben lényeges szerepet betöltő tényezőellátottság és a Helpman-Krugman modellben alkalmazott országonként különböző termékváltozatok.

Az IPR és a nemzetközi kereskedelem összefüggésének vizsgálatánál Maskus és Penubarti (1995) a kibővített Helpman-Krugman modell alapján 1984-es adatokból vizsgálják a szabadalmi védelem erősségének hatását a bilaterális importra 22 OECD ország és 71 különböző fejlettségi szintű partnerország között 28 iparágban. A partnerországokat a szerzők a piacuk mérete szerint nagy és kis országokra bontották a GDP-jük alapján. ${ }^{56}$ Az említett Helpman-Krugman modell nem vesz figyelembe olyan, kereskedelmet korlátozó tényezőket, mint például a szabadalmi védelem az egyes országokban, így ezek hatása a kereskedelemre a megfigyelt adatok és a modell előrejelzéseinek összevetéséből származtathatók.

Smith (1999) az USA 51 államára szúkíti a vizsgálódást, 96 partnerországgal szemben, akiket azonban már fejlettségi szint szerint csoportosít. 1992-es adatok alapján, és a gravitációs modellt használva vizsgálja az IPR hatását a kereskedelemre. Fink - Primo Braga (1999) szintén a gravitációs modellt alkalmazza 89 ország 1989-es bilaterális kereskedelmi adataira, iparági aggregátumokra nézve.

\footnotetext{
56 Nagy piacnak számítottak azok az országoknak ahol 18 milliárd dollárnál magasabb volt a GDP. Ezek között voltak nagyobb szegény, és kisebb, de magasabb jövedelmü országok.
} 
Park - Lippoldt (2008) egy egyszerü regressziós modellben vizsgálja az IPR és a nemzetközi kereskedelem közötti kapcsolatot számos kontroll változóval. A vizsgálatban 25 fejlett ország, 68 fejlődő és 27 kevésbé fejlett ország kereskedelmi és IPR adatai közti regressziót állít fel, ${ }^{57}$ az adatok azonban nem egyetlen évből származnak, hanem az 19902005 időszakot ölelik fel.

Co (2004) szintén a gravitációs modellre építve már keresztmetszeti és idősoros adatokat használ az 1970-1992 közötti időszakra az USA-ból 71 partnerországba irányuló export vizsgálatánál.

Ivus (2010) a korábbiaktól eltérően a különbségek különbsége (difference-indifferences) statisztikai módszerével vizsgálja 24 OECD ország és 55 fejlődő ország között a kereskedelmet mind keresztmetszeti adatok (szabadalom-érzékeny és nem szabadalomérzékeny iparágak) és idősorok (1960-2000) segítségével, hogy azonosítsa a szabadalmi védelemi szabályok változásának hatását. A módszer nem regressziót állít fel a független és a függö, valamint kontrollváltozók között, hanem azt mutatja meg, hogy a független változó szempontjából szignifikánsan különböző csoportok a függő változó szempontjából is szignifikánsan máshogyan viselkednek. A módszer a regressziótól eltérően nem a változók összetartozó nagyságai közötti összefüggést fejezi ki, hanem kategóriákat és ezek alapján esetkombinációkat képez, és ezek között lévő összefüggéseket vizsgál.

Az én empirikus kutatásom Ivus (2010) módszerére épül. Az eredeti statisztikai modellben az iparági szintű kereskedelem a befolyásoló tényezők függvényében az alábbi egyszerü módon adható meg:

$$
X_{i ; t}^{j}=f\left(\beta^{j} ; I P R_{i ; t} ; \alpha_{i} ; \alpha_{i ; t} ; \gamma^{j} ; \gamma_{t}^{j} ; \varphi_{t} ; u_{i, t}^{j}\right),
$$

amely összefüggésben $\mathrm{X}_{\mathrm{i}, \mathrm{t}}^{\mathrm{j}}$ az export aggregált nagysága $j$ iparágban $i$ importőr országba a $t$ időpontban; $\operatorname{IPR}_{\mathrm{i}, \mathrm{t}}$ az $i$ fejlődő országban érvényes szabadalmi védelmi szabályok erőssége $t$ időpontban; $\beta^{\mathrm{j}}$ koefficiens pedig az országonként állandó, de iparáganként különböző érzékenysége az exportnak az IPR védelem erősségére; $\alpha_{i}+\alpha_{i ; t}$ ország, illetve ország és időpont-specifikus befolyásoló tényezők vektora, például a távolság a kereskedelmi partnertől vagy az egy főre jutó GDP; $\gamma^{\mathrm{j}}+\gamma_{\mathrm{t}}^{\mathrm{j}}$ iparág, illetve iparág és

\footnotetext{
${ }^{57}$ Magyarázó változóként a regresszióban felhasználja az országban érvényes szabadalmi védelmi indexet, a szerzői jogvédelmi indexet és egy hogy managerek az adott országban egy felmérés alkalmával milyen erősnek mondták a szellemi tulajdonjogvédelmet. A kontrollváltozók közt szerepel az adott országbeli egy före jutó GDP, a jogrendszer hatékonysága (legal effectiveness), a vállalkozási szabadság mértéke (freedom to engage in trade), az üzletvitel költségessége (cost of doing business).
} 
időpont-specifikus tényezők; $\varphi_{t}$ az időpontokra vonatkozó dummy-változó, míg $u_{\mathrm{i} ; \mathrm{t}}^{\mathrm{j}} \mathrm{a}$ sztochasztikus hibatag. Az állandó tényezőket $\left(\alpha_{i} ; \gamma^{j}\right)$ a modell az által küszöböli ki, hogy változási, növekedési ütemet vizsgál függő változóként egy $T$ időszakra $\left(\Delta \mathrm{X}_{\mathrm{i} ; \mathrm{T}}^{\mathrm{j}}\right)$, a változások logaritmusbeli változások. Az országok és az iparágak közti különbségek kiszürésére használja Ivus (2010) a különbségek különbsége (difference in differenes, DiD) módszert.

A vizsgált országokat két csoportra osztja, intuitív módon volt gyarmatokra és nem volt gyarmatokra. Erről az egyszerü felosztásról F-teszt segítségével mutatja meg, hogy jól tükrözi az országok IPR változásában mutatkozó különbségeket: a volt gyarmatok esetében jobban nőtt az IPR-védelem, mint a nem volt gyarmatok esetében. A két csoport a fontos befolyásoló tényező tekintetében, ami az IPR védelem erősödése, szignifikánsan eltérően viselkedik. Ezek után a termékeket is két részre osztja, szabadalom-érzékeny, illetve nem szabadalom-érzékeny termékekre. Mindkét országcsoport esetében kiszámítva a növekedési ütemet adódik az alábbi, 5.1. táblázat.

5.1. táblázat. A különbségek különbsége módszer kimenete

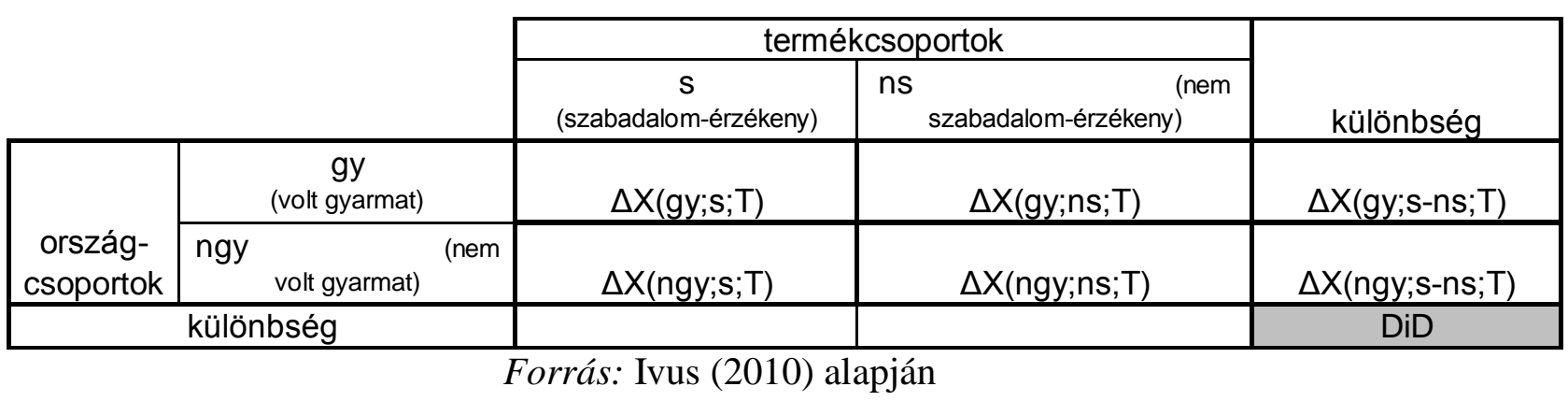

A táblázat felső sorának cellái közül $\Delta X_{g y ; T}^{s}$ a szabadalom-érzékeny termékexport növekedése a volt gyarmati országokba, $\Delta X_{g y ; T}^{n s}$ a nem-szabadalom-érzékeny termékek exportjának növekedése a volt gyarmati országokba. Ha az időszak alatt nőtt az export, akkor a táblázatban pozitív számok találhatók. Az alsó sor hasonlóan értelmezendő. A különbség-oszlopban található szám, $\Delta X_{g y, T}^{s-n s}=\Delta X_{g y ; T}^{s}-\Delta X_{g y ; T}^{n s}$ azt mutatja meg, hogy a szabadalom-érzékeny és a nem szabadalom-érzékeny termékexport egymáshoz képest hogyan változott a volt gyarmati országokban. Ha ez a különbség pozitív, akkor ez azt jelenti, hogy a szabadalom-érzékeny termékek exportja nagyobb mértékben nőtt, vagy kisebb mértékben csökkent, mint a nem szabadalom-érzékeny termékeké. Az alsó sor 
hasonlóan értelmezendő. A táblázat alján lévő mutató pedig $D i D=\Delta X_{g y, T}^{s-n s}-\Delta X_{n g y, T}^{s-n s}$ azt mutatja meg, hogy ez a különbség hogyan alakul a volt gyarmati és a nem volt gyarmati országok között. Ha a volt gyarmati országokban nagyobb mértékű a növekedés a szabadalom-érzékeny iparágakban a nem szabadalom-érzékenyekhez képest, mint a nem volt gyarmati országokban, akkor a mutató éréke pozitív. A mutató nullától való szignifikáns eltérését T-teszttel lehet tesztelni.

A módszer segítségével én az előző fejezetben modellezett összefüggéseket szeretném tesztelni. Az általam használt modell ezért annyiban lényegesen különbözik az Ivus (2010) tanulmányban alkalmazott modelltől, hogy míg ott a független változó az adott országra számított IPR védelem erőssége $\left(\operatorname{IPR}_{\mathrm{i}, \mathrm{t}}\right)$, illetve annak változása $\left(\Delta \mathrm{IPR}_{\mathrm{i} ; \mathrm{T}}\right)$ volt, addig az én vizsgálatomnál a lényeges az exportőr relatív IPR védelmi erőssége az importőréhez képest, amely a korábbiaknak megfelelően $\left(\operatorname{IPR}_{\mathrm{i} ; \mathrm{e} ; \mathrm{t}}=\frac{\operatorname{IPR}_{\mathrm{i} ; \mathrm{t}}}{\mathrm{IPR}_{\mathrm{e} ; \mathrm{t}}}\right)$ módon számítható ki, illetve ennek változása $\left(\Delta \mathrm{IPR}_{\mathrm{i}, \mathrm{e} ; \mathrm{T}}\right)$. A csoportok képzését ez alapján teszem meg.

\subsection{Empirikus adatok és forrásaik}

A vizsgálat célja, hogy összefüggést találjon a fejlődő országok IPR védelmének relatív erőssége és a fejlett országokból a fejlődőkbe irányuló termék export között. Az előző fejezet bontásának megfelelően bemutatom a használt adatokat, illetve azok forrását, és kiszámítását.

\subsubsection{A szabadalmi védelmi erősség relatív változásának mérése}

A szabadalmi védelem relatív erőssége alatt tehát két, egymással kereskedelmi kapcsolatban álló ország Ginarte-Park szabadalmi indexei közötti arányt értem. Legyen egy vizsgált fejlődő ország Thaiföld! Az IPR index értéke 1995-ben Thaiföldön 2,41, ami egy meglehetősen enyhe szabadalmi védelmet jelent. Egyik kereskedelmi partnere Belgium, ahol a védelem sokkal erősebb, 1995-ben 4,54. A thaiföldi szabadalmi védelem

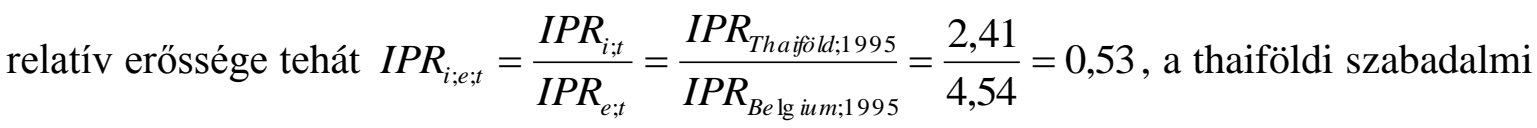


védelem tehát 0,53 -szor olyan erös (azaz csaknem fele olyan gyenge), mint a belga. ${ }^{58}$ 2000-re azonban mindkét országban szigorodott a szabadalmi védelem: Thaiföldön az index új értéke 2,53, míg Belgiumban 4,67. A thaiföldi védelem új relatív erőssége tehát $I P R_{\text {Tha iồ ld } ; B \text { lg } \operatorname{lium} ; 2000}=\frac{2,53}{4,67}=0,54$. Mivel a későbbi érték nagyobb, mint a korábbi, ez azt jelenti, hogy Thaiföld szabadalmi védelmének erőssége közelít Belgiuméhoz, vagyis a relatív szabadalmi jogvédelmi erősség nő, Thaiföld felzárkózik, legalábbis Belgiumhoz képest. Thaiföldön a szabályozás szigorodása nagyobb mértékű volt az adott időszak alatt, mint Belgiumban. Ez könnyen ellenőrizhető: $\Delta I P R_{i ; T}=\Delta I P R_{\text {Thaijo ld; } 1995-2000}=\frac{2,53}{2,41}=1,05$, az abszolút erősödés (szigorodás) tehát $5 \%$ Thaiföld esetében, míg Belgium esetében pedig csupán 3\%. A modellben a relatív IPR védelem változásának mérésére használt mutatószám pedig

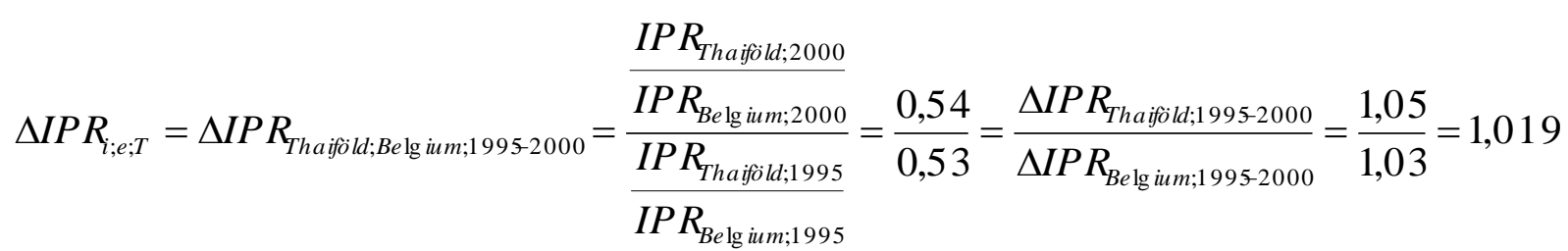

A relatív IPR védelem változását mérő mutató értéke nagyobb egynél, vagyis Thaiföld relatíve felzárkózik Belgiumhoz. A relatív védelem változása kiszámítható egyrészt a két időszak relatív védelmi erősségének hányadosaként, vagy átrendezve, a két ország IPR védelmi erősségének növekedési ütemei hányadosaként. A fejlődő ország tehát felzárkózik, ha az IPR védelem gyorsabban erösödik, mint a fejlett kereskedelmi partnerénél (az importőr lemaradása csökken, akár meg is elözheti az exportőrt). Egy másik példának azonban vegyük Németországot! Ott a szabadalmi védelem 4,17-ről 4,5-re nőtt a vizsgált időszakban, ami egy 8\%-os növekedés. Az exportőrnél nagyobb mértékben szigorodott a szabadalmi védelem, mint az importőrnél, így a fenti gondolatmenet értelmében az importőr lemaradt az exportőrtől (ha eredetileg előnye volt az exportőrrel szemben, ez az előny csökken, akár negatívvá is válhat). ${ }^{59}$ Thaiföldröl, mint országról, bár egyértelmüen eldönthető, hogy a szabadalmi védelem szigorodott vagy enyhült-e, nem

\footnotetext{
${ }^{58}$ Az előző fejezetben használt modellben az exportőr ország védelmi erőssége szerepelt a számlálóban, és az importőré a nevezőben. Az itt alkalmazott számítási mód az elöző fejezet jelölései szerint $\frac{1-\alpha_{i}}{1-\alpha_{e}}$.

${ }^{59}$ A statisztikai vizsgálatban valójában logaritmusok szerepelnek, így a relatív erősödést (felzárkózást) pozitív, a relatív gyengülést (lemaradást) negatív értékek jelzik a $\triangle I P R_{i: e ; T}$ tekintetében.
} 
mondható meg, hogy felzárkózó vagy lemaradó ország-e. A felzárkózás vagy lemaradás csak két ország viszonyában értelmezhető.

A különbségek-különbsége módszerhez szükséges csoportképzést tehát nem országokra (mint az eredeti Ivus (2010) tanulmányban), hanem országpárokra kell megtenni. Egy exportőr és egy importőr ország viszonyában három dolgot lehet a relatív IPR védelemmel kapcsolatban vizsgálni. Megnézhetjük az importőr relatív IPR védelmi erősségét a vizsgált időszak elején, a vizsgált időszak végén, és nézhetjük a két ország IPR védelmi erősségében bekövetkező változások arányát. Ez alapján elméletileg nyolc csoport képezhető, melyeket az 5.2. táblázat foglal össze.

5.2. táblázat. Az országpárok lehetséges csoportjai a relatív IPR védelmi erősség szempontjából

\begin{tabular}{|c|c|c|c|c|}
\hline \multicolumn{2}{|c|}{$\begin{array}{c}\text { az importör relatív IPR } \\
\text { védelme az exportörhöz } \\
\text { képest * }\end{array}$} & \multirow{2}{*}{\begin{tabular}{|c} 
importőt relatív \\
IPR védelmi \\
erősségének \\
változása
\end{tabular}} & \multirow{2}{*}{$\begin{array}{c}\text { példa országpár: } \\
\text { exportőr (IPR1995 } \rightarrow \text { IPR2000) és importör (IPR1995 } \rightarrow \text { IPR2000) }\end{array}$} & \multirow{2}{*}{ elnevezés } \\
\hline $\begin{array}{l}\text { az időszak } \\
\text { elején }\end{array}$ & $\begin{array}{l}\text { az időszak } \\
\text { végén }\end{array}$ & & & \\
\hline gyengébb & gyengébb & csökken & Ausztria $(4,21 \rightarrow 4,33)$ és Thaiföld $(2,41 \rightarrow 2,53)$ & lemaradók \\
\hline gyengébb & erősebb & csökken & matematikailag nem lehetséges ilyen eset & \\
\hline erösebb & gyengébb & csökken & Görögország $(3,47 \rightarrow 3,97)$ és Románia $(3,52 \rightarrow 3,72)$ & visszaesők \\
\hline erösebb & erösebb & csökken & Csehország $(2,96 \rightarrow 3,21)$ és Románia $(3,52 \rightarrow 3,72)$ & lelassulók \\
\hline erösebb & erősebb & növekszik & Csehország $(2,96 \rightarrow 3,21)$ és Bulgária $(3,23 \rightarrow 4,42)$ & elhúzók \\
\hline gyengébb & erösebb & növekszik & Csehország $(2,96 \rightarrow 3,21)$ és Argentína $(2,73 \rightarrow 3,98)$ & beelőzők \\
\hline erösebb & gyengébb & növekszik & matematikailag nem lehetséges ilyen eset & \\
\hline gyengébb & gyengébb & növekszik & Csehország $(2,96 \rightarrow 3,21)$ és Kína $(2,12 \rightarrow 3,09)$ & felzárkózók \\
\hline
\end{tabular}

* a gyengébb relatív IPR védelem azt jelenti, hogy $I P R_{i, e ; t}<1$, az erősebb pedig, hogy $I P R_{i, e ; t}>1$.

Forrás: saját szerkesztés

Bár az országpárok összesen hat csoportba lennének sorolhatóak, a kutatásban használt legnagyobb elemszámú specifikáció esetében is a vizsgált elemek 36,5 százaléka a legelső, míg 59,5 százaléka a legutolsó kategóriába esett, a többi kategória csak kis százalékban szerepelt. Ezért a kisebb arányban megjelenő kategóriákat összevontam a nagyobb arányban megjelenőkkel, és az országcsoportokat összesen két részre osztottam szét, méghozzá a relatív IPR védelmi erősség változása alapján: amely országpároknál az importőr relatív IPR védelmi erőssége csökkent, azok lettek a lemaradók (a táblázat első három létező kategóriája), míg ahol a relatív IPR védelem nőtt, azok lettek a felzárkózók. Feltételezésem szerint az első csoport esetében nagyobb lesz a High Technology iparágakban az import növekedése, mint a második csoport esetében. Ebben az esetben, 
bár kevésbé intuitív csoportosításról van szó, mint a volt gyarmat / nem volt gyarmat esetben, az F-teszt gyakorlatilag fölöslegessé válik annak vizsgálatára, hogy a csoportok jól szelektálnak-e a relatív IPR-változás alapján, hiszen eleve ez a rendező elv. Ennek ellenére az F-tesztet mindegyik későbbi vizsgálat esetében végrehajtottam, és az igazolta a csoportok relatív IPR-változás szerinti szignifikáns különbözőségét. ${ }^{60}$

Az IPR-indexek 1960-2005 intervallumban 5 évenkénti bontásban hozzáférhetőek. Én a három legutolsó időpont által jelöltem ki két időszakot a vizsgálatokhoz: 1995-2000 és 2000-2005.

A minta kiválasztásánál az alábbi szempontok vezéreltek. Elsősorban csak olyan országokat vehettem be a vizsgálatba, amelyek esetén a Ginarte-Park féle IPR-védelmi erősség mutatószáma ismert. Ez összesen 121 országot jelent. ${ }^{61}$ Ezeket szétválasztottam fejlett és fejlődő országokra, és a termékáramlást a fejlettektől (ők tehát az exportőrök) a fejlődők felé (ők pedig az importőrök) vizsgáltam. Ivus (2010) alapján azokat az országokat tekintettem fejletteknek, amelyek OECD tagországok. Ez összesen 32 országot jelentett, a többi 89 ország pedig a fejlődő volt. A fejlődőek közül egy további szempont volt a vizsgálatnál, szintén Ivus (2010) alapján, hogy csak azok kerültek be a mintába, amelyek WTO tagállamok, így 80 ország maradt. Az országok listáját a 4. számú melléklet tartalmazza. A vizsgálatokhoz még két további paraméter alapján szürtem a mintát. Egyrészt az importőr ország jövedelmi szintje szerint, másrészt az exportőr ország jövedelmi szintje szerint, harmadrészt pedig kereskedelmi volumen alapján. A Világbank négy jövedelmi kategóriába sorolja az országokat, úgy mint (1) alacsony, (2) alacsonyközép, (3) felső-közép és (4) magas jövedelmü. ${ }^{62}$ A szürést a mindenkori időszak elején érvényes jövedelemszint alapján végeztem.

\footnotetext{
${ }^{60}$ Egy másik, talán kevésbé direkt csoportosítás a Legal Origin elméletre épül (La Porta et al. 1998). Az elmélet lényege, hogy az egyes országok jogrendszerei néhány alapvetö közös eredetre vezethetőek vissza, úgy, mint angol, francia, német, szocialista és skandináv jogrendszer. Az országpárokat az alapján is képezhetjük, hogy az exportör és az importör azonos jogi eredettel bírnak-e, feltételezve, hogy a közös eredet nagyobb relatív IPR-erősödést fog eredményezni az importálónál, mint a különbözö. Az F-tesztet elvégezve azonban kiderült, hogy ez a fajta felosztás nem mutatja jól a két csoport közti különbséget a kérdéses változóban. Az instrumentális változó erősségét az F-teszttel mértem. Az instrumentum gyenge, ha az F-teszt értéke 8,96 alatt van (Stock et al., 2002). Ennél a fajta csoportosításnál azonban az F-teszt következetesen azt jelezte, hogy a közös jogi eredet gyenge csoportosító instrumentum.

${ }^{61} \mathrm{Az}$ indexek Walter G. Park honlapjáról származnak: http://www.american.edu/cas/faculty/wgp.cfm.

${ }^{62}$ Az egyes országok történelmi besorolására vonatkozó adatok a www.worldbank.org oldalról.
} 


\subsubsection{A tudásáramlás mérése}

Mint fentebb bemutattam, a nemzetközi tudásáramlás számos csatornán keresztül valósulhat meg. Ezek közül én csak az egyikre, az országok közötti termékáramlásra, illetve az azon keresztül végbemenő tudásáramlásra szükítem le a vizsgálódási keretet. Az exportőr és importőr országok azonosítása után az országpárokhoz tartozó kereskedelmi adatokat a COMTRADE adatbázisából szereztem be. Itt SITC Rev. 2 alapján szürhetőek a termékek, vagyis országpáronként lekértem a High Technology (HI), a Medium Technology (MED) és a Low Technology (LO) iparágakba tartozó bilaterális kereskedelmi értéket. Az iparágak csoportosítását a 3. számú melléklet tartalmazza. Nemcsak ezen három kategóriában hasonlítottam össze bármely kettőből a kereskedelem változását, hanem képeztem két összefoglaló kategóriát, a High és a Medium (HIMED), valamint a Medium és a Low (MEDLO) összegének változásait - ezeket is rendre összevetem a komplementer kategóriabeli kereskedelmi volumen alakulásával. Így minden időszakra 5 összehasonlítás tehető: HI vs MED, HI vs LO, MED vs LO, HIMED vs LO és HI vs. MEDLO.

Mivel az egyes országokban a szabadalmi jogszabályok változása nem egyszerre és egy időben, hanem fokozatosan és eltérő időpontokban valósul meg, ezért az exportban való alkalmazkodás is valószínüleg országonként különböző idő alatt következik be. A felhasznált export-adatok nem feltétlenül kell, hogy ugyanarra az időperiódusra vonatkozzanak, mint a szabadalmi index változása. A szakirodalom több helyen (Ivus 2010, Qiu - Yu 2010, Ginsberg 2006) alkalmaz egy vagy két éves késleltetést. Ennek oka egyrészt az, hogy időbe telhet, amíg a megváltozott IPR szabályozások kifejtik a hatásukat, a gazdasági szereplőknek időre van szükségük az alkalmazkodáshoz. A késleltetés másik oka, hogy ezzel kívánják kiküszöbölni az endogenitás problémáját, vagyis hogy az okokozati kapcsolat az IPR védelem erösödése és a termékforgalom alakulása között éppen fordított irányú, mint a feltételezések szerint: nem az IPR védelem erőssége határozza meg a termékforgalmat, hanem éppen a termékforgalom alakulása alapján alakítják az IPR védelmi szabályaik erősségét az egyes országok. A vizsgálatokat én 0 , 1 és 2 éves késleltetéssel egyaránt elvégeztem, továbbá a háromféle késleltetéssel mért adatok átlagára is. Így mind a két időszakhoz négyféle vizsgálat is tartozhat: az időszak átlagos kereskedelmi volumenének változása, vagy az időszak 0,1 vagy 2 évvel késleltetett kereskedelmi volumenének változásai.

Egy potenciális módszertani probléma lehet, hogy High Technology termékek nagy értékben kerülhetnek egy országba nemcsak végső fogyasztás, hanem további feldolgozás, 
majd a származási országba való visszajuttatás céljával is. A szakirodalom azonban következetesen az összes beáramlást tekinti mérvadónak a megfelelő iparágakból. E mögött az a feltételezés húzódhat meg, hogy ezek a termékek, amennyiben egyszer az országba bekerültek, már az ottani szabályok szerint néznek szembe az imitáció veszélyével.

Fontos probléma lehet még, hogy a nagyon alacsony kereskedelmi volumen torzíthatja a vizsgálatot, mivel egy nagyon kis abszolút változás az exportban nagyon nagy relatív változást eredményez. Ezért a vizsgálatokban a minta elemeit tovább szürtem kereskedelmi volumen alapján. Elvégeztem a vizsgálatokat bármely évre való kereskedelmi volumenre vonatkozó kikötés nélkül, valamint úgy is, hogy a mintába kerülö országok egyes évekre vonatkozó kereskedelmi volumenének minimumát 0 (legyen egyáltalán termékáramlás a két ország között), 5000, 20000, 50000 illetve 100000 euróban szabtam meg.

\subsection{Eredmények}

Vizsgáljuk meg kiindulási pontként azt a helyzetet, amikor az exportálók a magas jövedelemmel rendelkező OECD tagországok, az importálók pedig alacsony vagy alsóközepes jövedelmü WTO tagországok. Példaként csak azokat az országpárokat veszem be a vizsgálatba, ahol a kereskedelmi volumen minden vizsgált időszakban legalább 20000 euró. A kereskedelmi adatok késleltetése az IPR védelmi adatokhoz képest legyen az irodalomban gyakori 2 év (vagyis az első időszakban az 1997-2002, a második időszakban a 2002-2007 közti termékáramlást vizsgálom)! Ez 482 országpárt jelent az 1995-2000 időszakból, és 644 országpárt a 2000-2005 időszakból, összesen tehát egy 1126 országpárból álló mintát.

A mindkét időszakot egyaránt tartalmazó összevont elemzés kapcsán nincs értelme megvizsgálni az egyes csoportok időszak eleji, illetve végi IPR értékeit, azt viszont megvizsgálhatjuk, hogy a relatíve lemaradók esetében az átlagos IPR védelmi erősség az importőr országban az exportőr országénak csak 0,56-szorosa volt, míg a relatíve felzárkózók esetében 0,52-szöröse az időszak elején, a végén pedig 0,56-szoros, illetve 0,65-szörös. A relatíve IPR védelemben bekövetkező változás a felzárkózók esetében 0,2821, a lemaradók esetében pedig -0,0054, a (a különbség szignifikáns 1\% szignifikancia-szint mellett is). Az eredményeket az 5.3. táblázat mutatja be. 
5.3. táblázat. Különbségek különbsége kimeneti tábla: mindkét időszak együtt

\begin{tabular}{|c|c|c|c|c|}
\hline & \multicolumn{2}{|c|}{ termékcsoportok } & \multirow[b]{2}{*}{ különbség } \\
\hline & & $\begin{array}{c}\text { High Technology } \\
\text { (HI) }\end{array}$ & LowTechnology (LO) & \\
\hline \multirow{2}{*}{$\begin{array}{l}\text { országpár- } \\
\text { csoportok }\end{array}$} & relatíve felzárkózók & 0,5207 & 0,1478 & 0,3729 \\
\hline & relatíve lemaradók & 0,4037 & 0,2076 & 0,1961 \\
\hline \multicolumn{2}{|r|}{ különbség } & 0,1170 & $-0,0598$ & $0,17688_{0,057}$ \\
\hline
\end{tabular}

Megjegyzés: N = 1126, ebből relatíve felzárkózó 811 és relatíve lemaradó pedig 315.

Forrás: saját számítások

A különbségek különbségét két független mintás t-teszt segítségével vizsgáltam meg. A sötétített cellában található érték pozitív és szignifikáns (sig $=0,057)$, tehát a vizsgált országpárok között kijelenthetjük, hogy a relatíve felzárkózók esetében jobban nőtt a high technology iparágakban a behozatal, mint a relatíve lemaradók esetén, méghozzá $10^{0,1768}=$ 1,1934 szeresen, vagyis mintegy 19\%-kal nagyobb mértékben.

Csak az első időszakot vizsgálva a relatíve felzárkózók relatív IPR védelmi erőssége magas jövedelmü kereskedelmi partnereikhez képest az időszak elei 0,47-szeresről 0,60szorosra javult, míg a relatíve lemaradók esetében ugyanez az arány 0,50-szeresről változatlan maradt. A két csoport esetében a különbség szignifikáns 1\%-os szignifikancia szint mellett, a javulás a relatíve felzárkózók esetében 0,2954, míg a relatíve lemaradók esetében -0,0084. Ami a relatív felzárkózás vagy lemaradás hatását illeti a termékáramlásra, ismét pozitív, de nem szignifikáns különbség adódik (5.4. táblázat):

5.4. táblázat. Különbségek különbsége kimeneti tábla: az 1. időszak (1997-2002)

\begin{tabular}{|c|c|c|c|c|}
\hline & \multicolumn{2}{|c|}{ termékcsoportok } & \multirow[b]{2}{*}{ különbség } \\
\hline & & $\begin{array}{c}\text { High Technology } \\
(\mathrm{HI})\end{array}$ & LowTechnology (LO) & \\
\hline \multirow{2}{*}{$\begin{array}{l}\text { országpár- } \\
\text { csoportok }\end{array}$} & relatíve felzárkózók & 0,0738 & $-0,2206$ & 0,2944 \\
\hline & relatíve lemaradók & 0,1388 & $-0,0594$ & 0,1982 \\
\hline & különbség & $-0,0650$ & $-0,1612$ & $\begin{array}{c}0,0962 \\
\text { sig: } 0,485\end{array}$ \\
\hline
\end{tabular}

Megjegyzés: N = 482, ebből relatíve felzárkózó 329 és relatíve lemaradó pedig 153.

Forrás: saját számítások 
A második időszakot vizsgálva a relatíve felzárkózók relatív IPR védelmi erőssége magas jövedelmü kereskedelmi partnereikhez képest az időszak elei 0,55-szörösről 0,69szeresre javult. A relatíve lemaradók esetében ugyanez az arány 0,61-szeresről közel változatlan maradt. A különbség 1\%-os szignifikancia szint mellett szignifikáns, a javulás a relatíve felzárkózók esetében 0,2714, míg a relatíve lemaradók esetében -0,0014.

A második időszakban, ahogyan az 5.5. táblázat mutatja, ismét szignifikánsan (sig. = 0,067) jobban, 26\%-kal nagyobb mértékben nőtt a high tech termékimport a relatíve felzárkózó országpárok esetében, mint a relatíve lemaradóknál.

5.5. táblázat. Különbségek különbsége kimeneti tábla: a 2. időszak (2002-2007)

\begin{tabular}{|c|c|c|c|c|}
\cline { 3 - 4 } \multicolumn{2}{c|}{} & \multicolumn{2}{c|}{ termékcsoportok } & \multirow{2}{*}{ különbség } \\
\cline { 3 - 4 } \multicolumn{2}{c|}{$\begin{array}{c}\text { High Technology } \\
(\mathrm{HI})\end{array}$} & LowTechnology (LO) & \\
\hline \multirow{2}{*}{\begin{tabular}{c} 
országpár- csoportok \\
\cline { 2 - 4 }
\end{tabular}} & relatíve felzárkózók & 0,8258 & 0,3992 & 0,4266 \\
\cline { 2 - 5 } & relatíve lemaradók & 0,6539 & 0,4597 & 0,1942 \\
\hline \multicolumn{2}{|c|}{ különbség } & 0,1719 & $-0,0605$ & $\begin{array}{c}0,2324 \\
\text { sig: } 0,067\end{array}$ \\
\hline
\end{tabular}

Megjegyzés: N = 644, ebből relatíve felzárkózó 482 és relatíve lemaradó pedig 162.

Forrás: saját számítás

Ugyanilyen eredmények adódnak (szignifikáns pozitív különbség az összesített adatok és a második időszak esetében, pozitív, de nem szignifikáns különbség az első időszakban), ha a kereskedelmi volumen alsó határát 50000 vagy 100000 euróban állapítom meg. Ugyanez az összefüggés adódik, hogyha az importáló országok körét bővítem a felső-közepes jövedelmű országokkal, eltünik viszont, ha az exportáló országok közé beveszem a felső-közepes jövedelmü országokat. Legkövetkezetesebben az első időszak esetében jár együtt az IPR védelemben bekövetkező relatív erősödés a partnerországhoz képest és az erőteljesebben növekvő high tech import.

Egy nagyobb kép érdekében egy olyan specifikáció eredményeit szeretném bemutatni, melyben a vizsgált országok közé bevettem mindazokat az országokat, akik jelenleg OECD illetve WTO tagok, függetlenül a csatlakozás dátumától (így kezelte ezt Ivus (2010) is), valamint a jövedelmi szint alapján pedig azokat a párosításokat, amelyeknél az exportőr országok csak a magas jövedelmü fejlett országok, az importőrök pedig az alacsony, alsó-közép vagy felső-közepes jövedelmű fejlődő országok.

Az alábbi 5.6. táblázat mutatja az eredményeket (a táblázatban T1 és T2 az első-, illetve a második időszakot jelöli). A táblázatban már csak a különbségek különbsége értékek vannak feltüntetve (az 5.2-5.4. táblázatokban a sötétített cellában szereplő érték). A 10\%-os szignifikancia szint mellett szignifikáns különbségeket vastag betüvel szedtem. 
5.6. táblázat. Különbségek különbségei fontosabb eredmények.

\begin{tabular}{|c|c|c|c|c|c|c|c|c|c|c|c|c|}
\hline & \multicolumn{3}{|c|}{ kereskedelmi érték > 0} & \multicolumn{3}{|c|}{ kereskedelmi érték > 20000} & \multicolumn{3}{|c|}{ kereskedelmi érték > 50000} & \multicolumn{3}{|c|}{ kereskedelmi érték > 100000} \\
\hline & összevont & T1 & T2 & összevont & T1 & T2 & összevont & T1 & T2 & összevont & T1 & T2 \\
\hline & \multicolumn{12}{|c|}{ Különbségek a High Tech és a Medium Tech iparágak között } \\
\hline $\begin{array}{r}0 \text { év } \\
\text { késleltetés }\end{array}$ & 0,0995 & 0,0995 & 0,1172 & 0,0533 & 0,0916 & 0,0341 & 0,0858 & 0,1428 & 0,0510 & 0,0845 & 0,1560 & 0,0370 \\
\hline _sig & 0,14 & 0,27 & 0,21 & 0,33 & 0,24 & 0,65 & 0,11 & 0,07 & 0,48 & 0,11 & 0,04 & 0,61 \\
\hline $\begin{array}{r}1 \text { év } \\
\text { késleltetés }\end{array}$ & 0,0698 & 0,1278 & 0,0277 & 0,0671 & 0,0602 & 0,0922 & 0,0994 & 0,0985 & 0,1164 & 0,0961 & 0,1151 & 0,0886 \\
\hline __sig & 0,29 & 0,15 & 0,77 & 0,23 & 0,44 & 0,25 & 0,07 & 0,20 & 0,12 & 0,07 & 0,13 & 0,23 \\
\hline $\begin{array}{r}2 \text { év } \\
\text { késleltetés }\end{array}$ & $-0,0342$ & $-0,0099$ & $-0,0414$ & $-0,0084$ & $-0,0179$ & 0,0209 & $-0,006$ & 0,0076 & 0,0032 & $-0,0019$ & 0,0364 & $-0,0264$ \\
\hline$\ldots$ sig & 0,60 & 0,91 & 0,68 & 0,89 & 0,81 & 0,79 & 0,99 & 0,92 & 0,97 & 0,97 & 0,61 & 0,72 \\
\hline $\begin{array}{r}\text { időszak } \\
\text { átlag }\end{array}$ & 0,0844 & 0,0674 & 0,0969 & 0,1007 & 0,0915 & 0,1140 & 0,1109 & 0,1182 & 0,1071 & 0,0849 & 0,0658 & 0,1046 \\
\hline$\ldots$ sig & 0,06 & 0,28 & 0,11 & 0,02 & 0,15 & 0,05 & 0,01 & 0,06 & 0,06 & 0,06 & 0,30 & 0,08 \\
\hline & \multicolumn{12}{|c|}{ Különbségek a High Tech és a Low Tech iparágak között } \\
\hline $\begin{array}{r}0 \text { év } \\
\text { késleltetés }\end{array}$ & 0,0817 & 0,2691 & $-0,0862$ & 0,0204 & 0,1880 & $-0,1354$ & 0,0598 & 0,2155 & $-0,0866$ & 0,0483 & 0,1906 & $-0,0866$ \\
\hline$\ldots$ sig & 0,31 & 0,02 & 0,45 & 0,76 & 0,06 & 0,15 & 0,38 & 0,03 & 0,35 & 0,49 & 0,06 & 0,37 \\
\hline $\begin{array}{r}1 \text { év } \\
\text { késleltetés }\end{array}$ & 0,1594 & 0,1202 & 0,1942 & 0,1563 & 0,0987 & 0,2120 & 0,2191 & 0,2485 & 0,1927 & 0,1774 & 0,1766 & 0,1796 \\
\hline _sig & 0,05 & 0,29 & 0,10 & 0,02 & 0,32 & 0,02 & 0,00 & 0,01 & 0,03 & 0,01 & 0,07 & 0,04 \\
\hline $\begin{array}{r}2 \text { év } \\
\text { késleltetés }\end{array}$ & 0,0934 & 0,0264 & 0,1536 & 0,2201 & 0,1886 & 0,2489 & 0,1476 & 0,0925 & 0,1991 & 0,1358 & 0,1087 & 0,1613 \\
\hline _sig & 0,25 & 0,82 & 0,19 & 0,00 & 0,06 & 0,01 & 0,02 & 0,33 & 0,03 & 0,04 & 0,25 & 0,07 \\
\hline $\begin{array}{r}\text { időszak } \\
\text { átlag }\end{array}$ & 0,1066 & 0,1637 & 0,0556 & 0,1172 & 0,1829 & 0,0574 & 0,1166 & 0,1988 & 0,0411 & 0,1073 & 0,1478 & 0,0695 \\
\hline _ sig & 0,07 & 0,06 & 0,50 & 0,04 & 0,03 & 0,47 & 0,04 & 0,02 & 0,60 & 0,06 & 0,08 & 0,38 \\
\hline & \multicolumn{12}{|c|}{ Különbségek a High Tech és az összevont Medium és Low Tech iparágak között } \\
\hline $\begin{array}{r}\text { időszak } \\
\text { átlag }\end{array}$ & 0,0938 & 0,0798 & 0,1039 & 0,1089 & 0,0992 & 0,1220 & 0,1202 & 0,1379 & 0,1063 & 0,0958 & 0,0769 & 0,1150 \\
\hline _sig & 0,03 & 0,21 & 0,09 & 0,01 & 0,12 & 0,04 & 0,01 & 0,03 & 0,07 & 0,03 & 0,22 & 0,05 \\
\hline$N^{*}$ & 2171 & 1025 & 1146 & 1996 & 953 & 1043 & 1816 & 870 & 946 & 1639 & 789 & 850 \\
\hline ...ebböl & & & & & & & & & & & & \\
\hline $\begin{array}{r}\text { relatíve } \\
\text { felzárkózók }\end{array}$ & 1468 & 695 & 773 & 1346 & 638 & 708 & 1235 & 589 & 646 & 1127 & 541 & 586 \\
\hline $\begin{array}{r}\text { relatíve } \\
\text { lemaradók }\end{array}$ & 703 & 330 & 373 & 650 & 315 & 335 & 581 & 281 & 300 & 512 & 248 & 264 \\
\hline
\end{tabular}

Megjegyzés: az elemszám az időszaki átlagokra vonatkozik, az egyes késleltetések különböző, ennél nagyobb elemszámmal dolgoznak.

Forrás: saját számítások 
A táblázat néhány általánosan megfigyelhető tendenciát mutat be. Elöször is megfigyelhető, hogy jelentősen több esetben mutatható ki szignifikánsan különbözö viselkedés a lemaradó és felzárkózó országok között a high tech és a low tech iparágak kereskedelmi volumenjeinek alakulása között, mint a high tech és a medium tech iparágak között (és ez még inkább igaz a medium tech és low tech közti különbségekre). Csupán a high tech és a low tech iparágakra koncentrálva a vizsgálatok inkább megerösiteni látszanak a hipotézist. Érdekes módon éppen a késleltetés nélküli, elsö időszakra vonatkozó különbségek különbsége érték az, amely minden specifikációban pozitív és szignifikáns. Az, hogy a késleltetés nélküli értéket találtam rendre ilyennek, természetesen nem jelenti azt, hogy a gazdasági szereplők azonnal alkalmazkodnak a szabadalmi szabályozás változásához. A szabályozások változhatnak különböző időpontokban is, a szabadalmi védelmi index értékei azonban csak pillanatfelvételként mutatnak egy aktuális helyzetet: a tényleges változás elképzelhető, hogy az ötéves intervallum legelején következett be, de az is, hogy csupán az utolsó évben. Az pedig, hogy az első időszak mutat következetesebb képet, köszönhető lehet annak, hogy, mint ahogyan az 5.3-5.5. táblázat magyarázatainál írtam, a lemaradók és a felzárkózók nagyobb mértékű relatív IPR változásokon mentek keresztül az első, mint a második időszakban.

\subsection{Diszkusszió és az empirikus kutatás korlátai}

Ez a fejezet arra a kérdésre kereste a választ, hogy erőteljesebben hat-e a fejlődő országnak egy fejlett országból származó szabadalom érzékeny-termékimportjára, ha az importáló fejlett országban nem csak erősödik a szellemi tulajdonjog-védelem, hanem az adott konkrét kereskedelmi partneréhez képest relatíve erősödik. A kérdést a különbségek különbsége statisztikai módszerrel vizsgáltam. Az 5.6. táblázatban bemutatott specifikáció mellett azonban még más specifikációkban is megvizsgáltam a kérdést, mely specifikációk jelzik, mennyire robusztusak a vizsgálat eredményei.

Az első megvizsgálandó lehetőség, ahogyan az az 5.3-5.5. táblázatok és az 5.6. táblázat közti különbségben is megjelenik: hogyan vegyük figyelembe a kereskedelmi partnerek OECD, illetve WTO-beli tagságát? Elvégeztem a vizsgálatokat egyrészt úgy, hogy csak azok az országok legyenek az exportőrök (importőrök) között, akik a kérdéses időszak elején már OECD (WTO) tagok voltak (A specifikáció). Megnéztem az eredményeket úgy is, hogy csak annyi volt a feltételem, hogy az exportőr (importőr) ország jelenleg OECD (WTO) tagország legyen (B specifikáció). Végül megnéztem az országok 
OECD és WTO tagságára tekintet nélkül is az eredményeket (C specifikáció). Így minden specifikációhoz 840, összesen 840·3 = 2520 DiD eredmény tartozik. A specifikációk közti különbségeket az 5.7. táblázat mutatja be.

5.7. táblázat. Szignifikáns DiD értékek száma OECD/WTO tagság szerint

\begin{tabular}{|c|c|c|c|}
\hline késleltetés & A spec. & B spec. & C spec \\
\hline \multicolumn{4}{|c|}{ High tech és Medium tech közti különbségek } \\
\hline 0 év & 8 & 12 & 27 \\
\hline 1 év & 8 & 14 & 41 \\
\hline 2 év & 3 & 8 & 21 \\
\hline időszaki átlag & 4 & 22 & 37 \\
\hline összesen & 23 & 56 & 126 \\
\hline \multirow{2}{*}{\multicolumn{4}{|c|}{ High tech és Low tech közti különbségek }} \\
\hline & & & \\
\hline 0 év & 23 & 28 & 28 \\
\hline 1 év & 11 & 30 & 30 \\
\hline 2 év & 9 & 27 & 22 \\
\hline időszaki átlag & 0 & 29 & 29 \\
\hline összesen & 43 & 114 & 109 \\
\hline \multicolumn{4}{|c|}{ Medium tech és Low tech közti különbségek } \\
\hline 0 év & 19 & 24 & 18 \\
\hline 1 év & 6 & $4 \mid$ & 1 \\
\hline 2 év & 0 & 9 & 2 \\
\hline időszaki átlag & 4 & 13 & 3 \\
\hline összesen & 29 & 50 & 24 \\
\hline \multicolumn{4}{|c|}{$\begin{array}{l}\text { High és Medium tech összevontan és Low tech } \\
\text { közti különbségek }\end{array}$} \\
\hline idészaki átlag & 3 & 15 & 8 \\
\hline \multicolumn{4}{|c|}{$\begin{array}{c}\text { High tech és Összevont Medium és Low tech } \\
\text { közti különbségek }\end{array}$} \\
\hline időszaki átlag & 7 & 27 & 38 \\
\hline TOTAL & 105 & 262 & 305 \\
\hline
\end{tabular}

Magyarázat: A spec.: exportőrök (importőrök) a vizsgált időszakban OECD (WTO) tagok.

B spec.: exportőrök (importőrök) jelenleg OECD (WTO) tagok.

C spec.: minden exportörrel és importőrrel.

Forrás: saját számítások

A legtöbb szignifikáns különbséget (305 eset, a lehetséges esetek 36,3\%-a) a C specifikáció mutatja felzárkózók és lemaradók között, vagyis ha az országok körét a nemzetközi szervezetekben való tagságuktól függetlenül a lehető legszélesebben 
definiáljuk. ${ }^{63}$ A legrosszabbul pedig az a specifikáció teljesített (105 esetben, 12,5\%-ban találtam csak szignifikáns különbséget felzárkózó és lemaradó országok között), ahol csak olyanokat vettem be a mintába, akik a vonatkozó időszakban voltak a megfelelö nemzetközi szervezetek tagjai. A különbség egy lehetséges magyarázata a várakozásokban rejlik. Minthogy a TRIPS megállapodások a WTO tagországokat kötelezik, ezért az ő esetükben elöre lehetett látni a szabadalmi szabályozás megváltozását, míg a nem aláíró országokban pedig nem, így a tényleges változás eröteljesebben hathatott a kereskedelemre.

Az eredményeket befolyásolhatja a kereskedelmi partner országok jövedelemszintje is. Az exportáló és az importáló országok körére a jövedelemszint alapján szürve, összesen négy kombináció méltó említésre. Az I. kombináció esetében az exportáló országok közé csak a magas jövedelműeket, az importálók közé viszont az alacsony, alsó közepes és felső közepes jövedelműeket egyaránt bevettem. A II. kombinációnál ezt módosítottam úgy, hogy az importőrök közül kivettem a felső-közepes jövedelműeket. A III. kombináció esetében a bővítettem a II-hoz képest az exportálók körét felső-közepes jövedelmü exportőr országokkal, míg a IV. kombinációban pedig az exportálók magas és felsőközepes jövedelmủek, az importálók pedig alacsony, alsó- vagy felső-közepes jövedelműek. További lehetőségek adódnak, hogyha az exportálók körét bármely kombináció esetében bővíteném az alsó-közepes jövedelmi szintü exportőrökkel, vagy ha az importőrök közé venném be a felső-közepes jövedelmi kategóriájú fejlődő országokat is. Ezekben az esetekben azonban jóval kevésbé erős összefüggések adódtak, ezért csak azokra koncentrálok, amelyek az eredeti tendenciákat megtartották. Általánosságban elmondható, hogy a legkövetkezetesebben akkor mutatható ki a szignifikánsan különböző viselkedés a felzárkózó és lemaradó országok között, hogyha az exportőrök csak a magas jövedelemkategóriájú fejlett országok, az importőrök viszont az alsó három jövedelemkategóriából kerülnek ki, mint ahogyan az 5.6. táblázatban is ez a kombináció szerepelt. Minden specifikációnál összesen 630 DiD érték adódik, összesen tehát $630 \cdot 4=$ 2520. Az eredményeket az 5.8. táblázat mutatja be.

\footnotetext{
${ }^{63}$ Két nagy horderejú különbséget említenék meg. Oroszország nem WTO tag, így nem szerepelhet az A és B specifikációban, míg a C-ben pedig igen. Kína, minthogy 2001-ben csatlakozott, szintén csak a C specifikációban jelenhet meg.
} 
5.8. táblázat. Szignifikáns DiD értékek száma jövedelemcsoportok szerint

\begin{tabular}{|c|c|c|c|c|}
\hline késleltetés & k. I. & k. II. & k. III. & k. IV. \\
\hline \multicolumn{5}{|c|}{ High tech és Medium tech közti különbségek } \\
\hline 0 év & 11 & 3 & 12 & 21 \\
\hline 1 év & 33 & 11 & 8 & 11 \\
\hline 2 év & 12 & 11 & 3 & 6 \\
\hline időszak átlag & 26 & 9 & 11 & 17 \\
\hline összesen & 82 & 34 & 34 & 55 \\
\hline \multicolumn{5}{|c|}{ High tech és Low tech közti különbségek } \\
\hline 0 év & \begin{tabular}{r|}
14 \\
\end{tabular} & \begin{tabular}{r|}
16 \\
\end{tabular} & 23 & 26 \\
\hline 1 év & 31 & 17 & 9 & 14 \\
\hline 2 év & 19 & 25 & 11 & 3 \\
\hline időszak átlag & 19 & 18 & 11 & 10 \\
\hline összesen & 83 & 76 & 54 & 53 \\
\hline \multicolumn{5}{|c|}{ Medium tech és Low tech közti különbségek } \\
\hline 0 év & 19 & 11 & 8 & 23 \\
\hline 1 év & 1 & 5 & 3 & 2 \\
\hline 2 év & 0 & 9 & 2 & 0 \\
\hline időszak átlag & 2 & 11 & 3 & 4 \\
\hline összesen & 22 & 36 & 16 & 29 \\
\hline \multicolumn{5}{|c|}{$\begin{array}{l}\text { High és Medium tech összevontan és Low tech közti } \\
\text { különbségek }\end{array}$} \\
\hline időszak átlag & 3 & 14 & 6 & 3 \\
\hline \multicolumn{5}{|c|}{ High tech és Összevont Medium és Low tech közti különbségek } \\
\hline időszak átlag & \begin{tabular}{r|}
30 \\
\end{tabular} & 13 & \begin{tabular}{r|}
12 \\
\end{tabular} & 17 \\
\hline TOTAL & 220 & 173 & 122 & 157 \\
\hline
\end{tabular}

Magyarázat: $k$. I.: exportőr (importőr) jövedelemszint: 4 (1-3).

k. II.: exportőr (importőr) jövedelemszint: 4 (1-2).

k. III: exportőr (importőr) jövedelemszint: 3-4 (1-2).

k. $I V$ : exportőr (importőr) jövedelemszint: 3-4 (1-3).

\section{Forrás: saját számítások}

A legalsó sor mutatja, hogy a legtöbb esetben szignifikáns különbséget (220 eset, az adott specifikáció lehetséges eseteinek 34,9\%-a) a felzárkózók és lemaradók között az I. kombinációnál találtam. A legkevesebb esetben (122 eset, 19,4\%) akkor mutatható ki szignifikánsan különböző viselkedés felzárkózók és lemaradók között, ha a III. kombináció szerint vizságlódunk. Az I. kombináció a legígéretesebb, és ha ceteris paribus szúkítem az importálók, vagy bővítem az exportálók körét, kevesebb esetben találok szignifikáns különbséget a felzárkózók és lemaradók között.

Bár a hipotézis csak a high tech és a low tech iparágakat érintette, az adatgyüjtés során a medium tech iparágakban zajló kereskedelemre is gyüjtöttem adatokat, és ezeket is 
beemeltem az elemzésbe. Az 5.9. táblázatban az összes lehetséges fent említett specifikációval és jövedelmi kombinációkkal képzett eset szerepel, kétféle bontásban: egyrészt iparágak, másrészt időszakok szerint. Összesítve mindösszesen 2520 DiD mutatószámot kaptam, amelyek közül 672 (26,4\%) esetben lett szignifikáns a különbségek különbsége. Az összes specifikációt tekintve az alábbi 5.9. táblázat mutatja, hogy az egyes iparágak között hány alkalommal mutatható ki szignifikáns különbség a felzárkózók és a lemaradók között.

5.9. táblázat. Szignifikáns DiD értékek száma időszakok és iparágak szerinti bontásban

\begin{tabular}{|c|c|c|c|c|}
\hline \multirow[b]{2}{*}{ késleltetés } & \multicolumn{3}{|c|}{ időszak } & \multirow[b]{2}{*}{$\begin{array}{l}\text { mindösz- } \\
\text { szesen }\end{array}$} \\
\hline & összevont & T1 & $\mathrm{T} 2$ & \\
\hline \multicolumn{5}{|c|}{ High tech és Medium tech közti különbségek } \\
\hline 0 év & 18 & 27 & 2 & 47 \\
\hline 1 év & 27 & 21 & 15 & 63 \\
\hline 2 év & 14 & 5 & 13 & 32 \\
\hline időszak átlag & 24 & 29 & 10 & 63 \\
\hline Össesen & & & & 205 \\
\hline & & & & \\
\hline \multicolumn{5}{|c|}{ High tech és Low tech közti különbségek } \\
\hline 0 év & 0 & 55 & 24 & 79 \\
\hline 1 év & 29 & 34 & 8 & 71 \\
\hline 2 év & 26 & 14 & 18 & 58 \\
\hline időszak átlag & 18 & 40 & 0 & 58 \\
\hline összesen & & & & 266 \\
\hline \multirow{2}{*}{\multicolumn{5}{|c|}{ Medium tech és Low tech közti különbségek }} \\
\hline & & & & \\
\hline 0 év & 8 & 18 & 35 & 61 \\
\hline 1 év & 6 & 4 & 1 & 11 \\
\hline 2 év & 4 & 6 & 1 & 11 \\
\hline időszak átlag & 3 & 13 & 4 & 20 \\
\hline összesen & & & & 103 \\
\hline & & & & \\
\hline \multicolumn{5}{|c|}{$\begin{array}{c}\text { High és Medium tech összevontan és Low tech közti } \\
\text { különbségek }\end{array}$} \\
\hline időszak átlag & 4 & 19 & 3 & 26 \\
\hline \multicolumn{5}{|c|}{$\begin{array}{c}\text { High tech és Összevont Medium és Low tech közti } \\
\text { különbségek }\end{array}$} \\
\hline időszak átlag & 27 & 32 & 13 & 72 \\
\hline TOTAL & 208 & 317 & 147 & 672 \\
\hline
\end{tabular}

Magyarázat: T1: az első időszak (1995-2000). T2: a második időszak (2000-2005).

Forrás: saját számítások

Ha azt akarom megvizsgálni, hogy melyik iparág-párosítás vezet a legtöbb alkalommal szignifikánsan különböző eredményre a felzárkózók és lemaradók között, akkor az egyes szimpla iparág-összevetések esetében (HI vs MED, HI vs LO és MED vs LO) 720 DiD érték adódik. A legtöbb alkalommal (266 eset, az összes lehetséges eset 
36,9\%-a) szignifikáns különbséget a High tech és a Low tech iparágak tekintetében lehet felfedezni a felzárkózók és lemaradók között. Erre vonatkozott a hipotézis is, ileltve a 4. fejezet modellje. A legkevésbé ,sikeres” párosítás a Medium tech és a Low tech: mindössze 103 esetben (14,3\%) különbözik szignifikánsan a felzárkózó és a lemaradó országok importja: ezek az iparágak a vizsgálat szempontjából közel állnak egymáshoz. Ami a két öszevont kategóriát illeti (HIMED vs LO és HI vs MEDLO), itt 180-180 eset lehetséges. A két lehetőség közül jóval nagyobb arányban mutat szignifikáns különbséget a felzárkózók és a lemaradók viselkedése, ha a Medium techet a Low techhel vonom össze, és úgy vetem össze a High Tech iparágakkal (72 eset, 40\%).

A kutatás egy lehetséges továbbfejlesztési iránya az iparágak választott csoportosításának megváltoztatása. Ivus (2010) például a high tech iparágak közül kihagyja a vizsgálatából azokat, melyeket más szellemi tulajdonjogi mechanizmusok védenek (pl. szerzői jog). Érdemes lehet továbbá az irodalomban fellelhető további csoportosításokban is megvizsgálni, hogy hogyan reagál a fejlett országokból a fejlődőekbe irányuló szabadalom érzékeny, vagy szabadalom intenzív vagy high-tech termékexport a relatív IPR védelem változására.

Ami az 5.9. táblázatban szintén jelölt időszakokat illeti, egy-egy időszakhoz (összevont, T1 és T2) 840 DiD érték tartozik. Megvizsgálva, hogy mely időszakban mutatható ki legtöbbször szignifikánsan különböző viselkedés a lemaradó és a felzárkózó országcsoportok között, az 5.9. táblázat azt mutatja, hogy a legtöbb esetben (317 esetben, ami az összes lehetséges eset 37,7\%-a) szignifikáns különbség az első időszakban mutatható ki, a legkevesebb esetben pedig $(17,5 \%)$ a második időszakban. A különbséget én abban látom, hogy a második időszakra lelassult a szabadalmi védelmi index változása az első időszakhoz képest. A Ginarte - Park féle szabadalmi index 5 évenként kerül kiszámításra, legutóbbi publikált állapota a 2005-ös helyzetről ad képet. Ha publikálásra kerülnek a 2010-es adatok, akkor egy újabb vizsgálat megmutathatja, hogy tovább lassult-e a relatív szabadalmi védelmi erősség változása, és ez tovább mérsékelte-e a szignifikáns különbségeket az iparágankénti termékáramlásban a lemaradók és felzárkózók között.

Mindenesetre érdekes, hogy az időszakonkénti és az iparágankénti összefüggések, melyeket az 5.9. táblázat mutat, jól megmaradnak a fentebb említett különböző specifikációk és jövedelmi kombinációk esetében is, ami ezen eredmények megbízhatóságát erősíti.

További lehetséges továbbfejlesztési irány, hogy található-e olyan instrumentum, mely megfelelőbben válogatja szét az ország-párokat a relatív IPR védelem erősödése 
szempontjából, mint például a közös eredetü jogrendszer, ugyanakkor szignifikánsabb különbséget mutat a kereskedelmi volumen alakulásában a felzárkózó és lemaradó országok között.

A rendelkezésre álló adatok lehetővé teszik egy-egy exportáló ország vagy országcsoportra leszükíteni a vizsgálódást, és megnézni, hogy az általam feltételezett hatás erősebben vagy kevésbé erősen érvényesül, mint ha aggregáltan kezelném az exportálókat. Kézenfekvő választás lenne elsőként Magyarország, mint fejlett exportőr (legalábbis jelenlegi kutatásom szóhasználata szerint fejlett, vagyis OECD tagország) esetében megvizsgálni, érvényesek a fenti összefüggések. Magyarország mindkét vizsgált időszakban csak felső-közepes szintü jövedelmü ország. Az összevont elemzés azt mutatta ki, hogy a felső-közepes jövedelmű exportőrök bevétele a mintába rontja az eredmények szignifikanciáját, ami arra enged következtetni, hogy ha csak egyetlen ilyen országot vizsgálunk, akkor nem lesz kimutatható jelentős különbség az egyes iparág-csoportok exportjának alakulásában az importőr relatív szellemi tulajdonjogvédelmi erőssége függvényében. 


\section{A disszertáció eredményei}

A disszertáció központi témája a szabadalmaknak az innovációban, tudástermelésben és tudásterjedésben betöltött hatása. Az innovációs irodalomnak egy specializált szegmense foglalkozik kifejezetten a szabadalmi intézményrendszerrel. Mikromodellek egész sora épült fel arra, hogy tanulmányozza a szabadalmi erősség hatását a kutatásfejlesztésre, innovációra, és közvetetten a jólétre. A szabadalmi erősség persze nem egy egydimenziós fogalom, így a szakirodalom részletesen tárja fel a különböző szabadalmakkal kapcsolatos jogi szabályozásoknak a hatásait az egészen egyszerű statikus és determinisztikus modellektől a legbonyolultabb dinamikus és sztohasztikus modellekben. A szabadalmi védelem hossza mindezen elemzésekben egy kulcsfontosságú változó.

Disszertációmban először az optimális szabadalmak elméletének megállapításaihoz kívántam hozzájárulni. Az optimális szabadalmak elmélete azzal foglalkozik, hogy megállapítsa a szabadalmi védelmi rendszer optimális felépítését. A szabadalmi védelem paramétereit úgy igyekszik meghatározni, hogy a vállalatokat, azokról profitmaximalizáló viselkedést feltételezve, társadalmi szempontból optimális mennyiségü kutatás-fejlesztési erőforrásráfordításra ösztönözze. A szabadalmi védelmi rendszer erősségének egy kulcsfogalma a szabadalmi élettartam. A szabadalmi élettartam azért kap nagy szerepet, mert a kutatás-fejlesztés és innováció időben korábban jelentkező költségek árán egy időben a vállalat számára később realizálódó többlet-hasznot, a fogyasztók számára pedig egy időben még később jelentkező fogyasztói többlet-növekedést eredményez. Ezeknek a más-más időben keletkező hasznoknak és költségeknek a megfelelö összevetése szükséges ahhoz, hogy a szabadalmi védelem optimális időtartama meghatározható legyen.

Gazdaságpszichológiai tanulmányaim során azonban találkoztam a kísérleti közgazdaságtan azon felvetésével, hogy az emberek mentális diszkontálási viselkedése valójában nem olyan, mint amilyennek a pénz időértékének kiszámításakor azt feltételezzük. Ezt a - nem-exponenciális - mentális diszkontálási modellt építettem be a dolgozatomban az optimális szabadalmak elméletébe. A szakirodalom ezt a fajta modellt eddig még pénzáramok jelenértékének kiszámítására nem használta. Amellett érveltem, hogy amennyiben jövőbeli pénzhozamok jelenértékének számítása a feladat, akkor továbbra is az exponenciális diszkontálási modell az adekvát. A nem-exponenciális 
diszkontálást ezzel szemben olyan esetekben kell alkalmazni, amikor „mentális hozamok” (mint amilyen például a jövőben potenciálisan megszerezhető fogyasztói többletnövekmény) jelenértékét kell meghatározni. A diszkontfüggvényeket összehasonlítva azt találtam, hogy az exponenciális diszkontálás a nem-exponenciálishoz képest a valamilyen $T$ időponttól a végtelenig jelentkező halasztott örökjáradékokat többnyire alulértékeli. Az általam felhasznált modellben az innováció időpontja változtatható volt. A szabadalmi hosszúság növelése mindig korábbra hozza az innováció időponját, a szabadalom lejártának időpontját viszont egy ideig csökkenti, majd növeli. A nem exponenciálisan diszkontáló fogyasztókra jellemző rövid távú nagyobb türelmetlenség és hosszú távú nagyobb türelem (az exponenciális diszkontáláshoz képest) mindenképpen csökkenti a szabadalom optimális élettartamát. Az élettartam csökkenése a modellben korábbra hozza a szabadalom lejáratát, viszont későbbre tolja magát az innovációt, az exponenciálishoz képest.

A lehetséges leghamarabbi lejáratot eredményező szabadalmi hosszhoz képest addig érdemes növelni a szabadalom élettartamát, amíg a növelésből származó költségek jelenértéke meg nem egyezik a növelésből származó hasznok jelenértékével. Az időben később keletkező költségek jelenértékét azonban a kvázi-hiperbolikusan diszkontáló fogyasztó gyengébben diszkontálja a hosszú távú nagyobb türelem miatt, ugyanakkor az időben közelebb jelentkező hasznokat pedig a rövid távú nagyobb türelmetlenség okán erősebben - mindezt az exponenciális esethez viszonyítva. A költségek és hasznok így már egy a minimális fölötti kisebb élettartam-növelésnél kiegyenlítődnek. A hosszú távú nagyobb türelem ugyanakkor nem egyszerüen a kamatláb csökkenése miatt mutatja ezt a hatást: a diszkontálási modellt megtartva és abban csökkentve a kamatlábat nem az optimális szabadalmi idő csökkentése lenne a modell előírása. A diszkontálási modell megváltoztatása minőségi különbséget eredményezett az optimális szabadalmi élettartamot illető gazdaságpolitikai ajánlásban.

A későbbiekben érdemes lehet akár bonyolultabb modellekbe is beépíteni ezeket az alternatív diszkontálási modelleket, vagy a nem optimális szabadalmak által okozott jóléti veszteségeket ilyen diszkontálás mellett számszerüsíteni. A további modell-változatokba való beépítés megmutathatja, mennyire robusztus a bemutatott összefüggés.

Az optimális szabadalmak elmélete azonban csak egy a számos lehetséges alkalmazási terület közül. A tanulmányban felvetett optimalizációs probléma egy általánosabb tárgykör, a Ramsey-problémák egy fajtája. A Ramsey-problémák során a kormányzat úgy igyekszik valamilyen cselekvési paraméter optimális nagyságának 
meghatározására, hogy bizonyos korlátozó feltételek mellett maximális társadalmi jólét legyen elérhető. Az általam bemutatotthoz hasonlóan tehát a kvázi-hiperbolikus diszkontálás beépíthető akár olyan területeken is, mint az optimális adópolitika vagy a zsúfoltságra hajlamos javak optimális szabályozása.

Disszertációm második nagy vizsgálódási területe a szabadalmi védelmi erösség hatása volt a termékek nemzetközi kereskedelmére. A szakirodalomban a szabadalmi intézményrendszer erősségét nem egy mutatószám határozza meg (mint amilyen az optimális szabadalmak elmélete esetében a szabadalmi védelem hossza volt), hanem egy komplex mutatószám, amely a szabadalmi védelem hosszán túl más tényezőket is figyelembe vesz. A szakirodalomban széles körben kutatott téma, hogy a fejlődő országok szabadalmi védelmi rendszerének erősítése milyen hatással lesz az ezen országokba érkező termékimportra (és ezen keresztül az ottani jólétre, közvetetten pedig az innovációra és gazdasági növekedésre). Az elméleti és empirikus irodalom azonban csak a szellemi tulajdonjogi rendszerek erősségének abszolút változására, illetve ennek hatásaira koncentrál. Ebben a szemléletmódban egyértelműen megállapítható, hogy egy importáló ország helyzete javult-e vagy romlott. A helyzetének javulását a szabadalmi védelmi index növekedésével, romlását pedig annak csökkenésével azonosítja az irodalom.

Én azonban amellett érveltem, hogy az ország helyzetének változása abszolút értelemben nem, hanem relatívan értelmezendő: valamely kereskedelmi partneréhez képest. Így a nemzetközi termékáramlás magyarázó tényezőjeként bevezettem a relatív szabadalmi védelmi erősség, és annak változása fogalmait. A relatív szellemi tulajdonjogvédelmi erősség változásának hatása a szakirodalomban nem vizsgált téma. Egy fejlődő ország szabadalmi védelme relatíve erősödik, ha a védelem erőssége időben közelít a fejlett kereskedelmi partnerénél érvényben lévő védelem erősségéhez.

A relatív védelmi erősség változásának hatásait vizsgálandó először egy modellbe építettem be. A modell tanúsága szerint egy fejlett országból egy fejlődő országba irányuló termékforgalom nem csupán az importőr ország szabadalmi védelmi erőssége által befolyásolt, hanem hatással van rá az exportôr országban érvényes IPR védelem is. A modellben mind a két ország szabadalmi védelmi erőssége befolyásolta az imitációk megjelenésének valószínűségét, így mindkettő hatással volt a fejlett országbeli termelők exportálási döntésére. Másodszor a modell megmutatta, hogy az IPR erősödés önmagában véve mindenképpen exportbevonzó hatással bír, bármelyik országban történjék is meg a szabályok szigorodása. A fejlődő országbeli szabályozás erősségének relatív változása 
(relatív erősödése, felzárkózása, vagy relatív gyengülése, lemaradása) így a termékforgalom változásának irányát nem, csak a nagyságát befolyásolta. A fejlődő importőr ország adott nagyságú szabadalmi védelmi szigorodása mellett az exportőr ország szabályozása ha kisebb mértékben szigorodott, vagyis az importőr felzárkózott, akkor az imitációs határkockázat, vagyis a beáramló termékek köre kisebb mértékben nőtt, mintha az exportőr ország szabályozása nagyobb mértékben szigorodott volna, az importőr ország lemaradását eredményezve. Harmadszor a modell azt mutatta, hogy az exportőr országbeli IPR védelem relatív erősödése nagyobb mértékben hat a high-tech termékekre, mint a lowtech termékekre. A relatív gyengülés esetében pedig a low-tech termékek forgalmában következik be nagyobb mértékű változás, mint a high-techben.

A disszertáció végén a modellem alapján empirikusan is megvizsgálom, hogy a modell által elörejelzett összefüggések valóban kimutathatóak-e. Feltételezésem szerint azoknál az országpároknál, ahol az importőrnél érvényes IPR védelem relatíve erősödött a fejlett exportőr kereskedelmi partneréhez képest, a low-tech termékek behozatalához képest a high-tech termékek behozatala nagyobb mértékben fog nőni, mint a relatíve gyengülő importőr-exportőr kereskedelmi pároknál. A vizsgálatom nem mutat ki egyértelmü összefüggést. Mindazonáltal a hipotézisemet elvetnem sem érdemes: a specifikáló tényezők bizonyos kombinációi mellett egész jól mutatja a statisztikai modell a feltételezett különbségeket. Ha az exportáló országok körét a jelenlegi magas jövedelemmel rendelkező OECD tagokban határozom meg, míg az importálók pedig azok az alacsony, alsó-közepes és felső-közepes jövedelemmel bíró jelenlegi WTO tagországok, amelyekre a Ginarte-Park szabadalmi index elérhetö, akkor a high-tech és a low-tech iparágakbeli termékek áramlásában szignifikáns különbséget mutatnak a relatíve lemaradók és a relatíve felzárkózók. A relatíve felzárkózók esetében ugyanis a high-tech import nagyobb mértékben nőtt a low-tech importnál, a relatíve lemaradókhoz képest.

Mindenesetre mind a modell, mind pedig az empíria alapján érdekes további kutatási iránynak tünik a lemaradás-felzárkózás mint befolyásoló tényező vizsgálatat. Fontos lehet a mellette ható jelentősebb tényezők azonosítása (imitációs képesség, abszorptív kapacitás mérése, jövedelmi különbségek). A relatív szabadalmi védelmi erősség változásának hatását érdemes lehet megvizsgálni bizonyos országcsoportokra, vagy a tudásterjedés más csatornáira (pl. FDI) is. 


\section{Irodalomjegyzék}

Ács, Z. J. - Varga Attila (2000) Térbeliség, endogén növekedés és innováció. Tér és Társadalom, 4., 23-38. o.

Aghion, P. - Howitt, P. (1998) Endogenous Growth Theory. MIT Press, Cambridge, Massachusetts

Ainslie, G. (1992) Picoeconomics: The Strategic Inteaction of Successive Motivational States within the Person. Cambridge University Press, New York

Angeletos, G-M. - Laibson, D. - Repetto, A. - Tobacman, J. - Weinberg, S. (2001) The Hyperbolic Consumption Model: Calibration, Simulation and Empirical Evaluation. Journal of Economic Perspectives, 3., 47-69. o.

Antonelli, C. (1999) The evolution of the industrial organisation of the production of knowledge. Cambridge Journal of Economics, 23., 243-260. o.

Antonelli, C. (2004) The Governance of Localized Technological Knowledge and the Evolution of Intellectual Property Rights. In Colombatto, E. (ed.) The Elgar Companion to the Economics of Property Rights. Edward Elgar, Cheltenham, 414437. o.

Arrow, K. J. (1962a) The economic implications of learning by doing. Review of Economic Studies, 29., 155-173. o.

Arrow, K. J. (1962b) Economic welfare and the allocation of resources for invention. In Nelson, R. R. (ed.) The Rate and Direction of Inventive Activity. Princeton University Press, Princeton, 609-625. o.

Asheim, T. B. - Coenen, L. - Moodysson, J. - Vang, J. (2005) Regional Innovation System Policy: a Knowledge-based Approach. CIRCLE (Lund University) Working Paper, WP2005/13. online: http://www.circle.lu.se/upload/CIRCLE/workingpapers/ 200513_Asheim_et_al.pdf, letöltve: 2012. augusztus 16.

Asheim, T. B. - Coenen, L. (2006) Tudásbázisok és regionális innovációs rendszerek: skandináviai klaszterek összehasonlítása. Információs Társadalom, 3., 114-141. o.

Bajmócy Zoltán (2008) A regionális innovációs képesség értelmezése és számbavétele a tanulás-alapú gazdaságban. In Lengyel Imre - Lukovics Miklós (szerk.) Kérdőjelek a régiók gazdasági fejlödésében, JATEPress, Szeged, 26-46. o. 
Boettke, P. J. (2002) Information and Knowledge: Austrian Economics in Search of its Uniqueness. The Review of Austrian Economic, 4., 263-274. o.

Boisot, M. - Canals, A. (2004) Data, information and knowledge: have we got it right? Journal of Evolutionary Economics, 14., 43-67. o.

Boldrin, M. - Levine, D. K. (2005) Innováció - a verseny szemszögéből. Közgazdasági Szemle, 6., 537-555. o.

Boulding, K. (1966) The Economics of Knowledge and the Knowledge of Economics. American Economic Review, 1., 1-13. o.

Bozkirloglu, B. B. (2006) The Characteristics of Knowledge in Evolutionary Economics. Science and Technology Policy Studies Working Paper No. 603.

Cairns, J. (2006) Developments in discounting: with special reference to future health events. Resource and Energy Economics, 3., 282- 297. o.

Chin, J. C. - Grossman, G. M. (1988) Intellectual Property Rights and North-South Trade. NBER working paper No. 2769.

Co, C. Y. (2004) Do Patent Rights Regimes Matter? Review of International Economics, 3., 359-373. o.

Coase, R. H. (1960) The problem of the sotial costs. Journal of Law and Economics, 3., 144. 0 .

Cohen, W. M. - Nelson, R. R. - Walsh, J. P. (2000) Protecting their Intellectual Assets: Appropriability Conditions and Why U.S. Manufacturing Firms Patent (or Not). NBER Working Paper no. 7552.

Cropper, M. - Laibson, D. (1998) The Implications of Hyperbolic Discounting for Project Evaluation. Wold Bank, Policy Research Working Paper No. 1943.

Czeglédi P. (2009) A tulajdonjogi biztonság szerepe a technológia elterjedésében. Közgazdasági Szemle, 9., 790-813. o.

David, P. A. (1992) The Evolution of Intellectual Property Institutions and the Panda's Thumb. Online: http://www.compilerpress.atfreeweb.com/Anno\%20David\%20Evolu tion\%20of\%20IP\%20Institutions\%201992.htm, letöltve: 2008.6.26.

Deardorff, A. (1992) Welfare effects of global patent protection. Economica, 59., 35-51. o.

Denicoló, V. (1996) Patent Races and Optimal Patent Breadth and Length. The Journal of Industrial Economics, 3., 249-265. o.

Denicoló, V. (2000) Two-stage Patent Race and Patent Policy. RAND Journal of Economics, 3., 488-501. o. 
Dornbusch, R. - Fischer, S. - Samuelson, P. A. (1977) Comparative Advantage, Trade, and Payments in a Ricardian Model with a Continuum of Goods. American Economic Review, 67., 823-839. o.

Duffy, J. F. (2005) A Minimum Optimal Patent Term. Law and Technology Scholarship, elérhető online: http://www.escholarship.org/uc/item/9zs6f4cv

Eaton, J. - Kortum, S. (1999) International Technology Diffusion: Theory and Measurement. International Economic Review, 3., 537-570. o.

Falvey, R. - Foster, N. (2006) The Role of Intellectual Property Rights in Technology Transfer and Economic Growth: Theory and Evidence. UN Industrial Development Organisation, Vienna

Faulkner, W. (1994) Conceptualizing Knowledge Used in Innovation: A Second Look at the Science-Technology Distinction and Industrial Innovation. Science, Technology \& Human Values, 4., 425-458. o.

Feenstra, R., C. - Markusen, J., R. - Rose, A., K. (2001) Using the Gravity Equation to Differentiate among Alternative Theories of Trade. The Canadian Journal of Economics, 2., 433-447. o.

Ferrantino, M., J. (1993) The effect of intellectual property rights on international trade and investment. Weltwirtschaftliches Archiv, 129., 300-333. o.

Fink, C. - Primo Braga, C. A. (1999) How Stronger Protection of Intellectual Property Rights Affects International Trade Flows. World Bank, Policy Research Working Paper No. 2051.

Fisher, I. (1930) The Theory of Interest. Macmillan, New York

Foray, D. (2004) The Economics of Knowledge. MIT Press, Cambridge

Frederick, S. - Loewenstein, G. - T. O’Donoghue, T. (2002) Time Discounting and Time Preference: A Critical Review. Journtal of Economic Literature, 6., 351-401. o.

Garud, R. (1997) On the Distinction Between Know-How, Know-Why and Know-What. Advances in Strategic Management, 14., 81-101. o.

Gallini, N. (1992) Patent Policy and Costly Imitation. RAND Journal of Economics, 1., 5263. 0

Ghosh, S. (2003) Globalization, Patents and Traditional Knowledge. Columbia Journal of Asian Law, 1., 73-120. o.

Ghosh. A. - Ishikawa, J. (2010) IPR protection and absorptive capacity in north-south trade. Preliminary draft, online: http://staff.cbs.dk/prm/Ishikawa.pdf, letöltve: 2012. június 11. 
Gilbert, R. - Shapiro, K. (1990) Optimal Patent Length and Breadth. RAND Journal of Economics, 1., 106-112. o.

Ginarte, J. C. - Park, W. G. (1997) Determinants of patent rights: A cross-national study. Research Policy, 26., 283-301. o.

Ginsberg, M. (2006) The Effects of Intellectual Property Protection on Growth in Transition Economies. BA thesis, online: https://www.amherst.edu/media/view/ 7739/original/ Ginsberg05.pdf .

Glass, A. J. - Wu, X. (2007) Intellectual Property Rights and Quality Improvement. Journal of Development Economics, 82., 393-415. o.

Goenner, C. F. - Silva, P. (2009) The effect of asymmetries in relative factor endowments on international trade. mimeo, Department of Economics, University of North Dakota

Grossman, G. M. - Helpman, E. (1991a) Quality Ladders in the Theory of Growth. The Review of Economic Studies, 1., 43-61. o.

Grossman, G. M. - Helpman, E. (1991b): Quality Ladders and Product Cycles. Quarterly Journal of Economics, 106., 557-586. o.

Hámori Balázs (2005) „Globális bazár” vagy digitális monopólium? Külgazdaság, 1-2., 58-79. o.

Hámori Balázs (2012) Tanulás - invenció - innováció: elméleti dilemmák és gyakorlati nézőpontok. In Hámori B. - Szabó K. (szerk.) Innovációs verseny. Esélyek és korlátok. Aula Kiadó, Budapest, 47-72. o.

Hayek, F. A. (1954) The Use of Knowledge in Society. American Economic Review, 4., 519-531. o.

Helpman, E. (1993) Innovation, Imitation and Intellectual Property Rights. Econometrica, 6., 1247-1280. o.

Hoekman, B. - Maskus, K. E. - Saggi, K. (2005) Transfer of technology to developing countries: Unilateral and multilateral policy options. World Development, 10., 15871602. o.

Hopenhayn, H. - Llobet, G. - Mitchell, M. (2006) Rewarding Sequential Innovations: Prizes, Patents and Buyouts. Journal of Political Economy, 6., 1041-1068. o.

Hu, A. G. Z. - Png, I. P. L. (2009) Patent Rights and Economic Growth: Evidence from Cross-Country Panels of Manufacturing Industries. National Universtiy of Singapore Business School, kézirat, elérhető online: http://www.wipo.int/edocs/ mdocs/mdocs/en/wipo_ip_econ_ge_5_10/wipo_ip_econ_ge_5_10_ref_huandpng.pdf 
Inzelt Annamária (2011) Innováció és nemzetköziesedés a kicsik világában. Egy e-felvétel eredményei. Külgazdaság, 9-10., 122-154. o.

Ivus, O. (2010) Do stronger patent rights raise high-tech exports to the developing world? Journal of International Economics, 81., 38-47. o.

Ivus, O. (2011) Trade-related intellectual property rights: industry variation and technology diffusion. Canadian Journal of Economics, 1., 201-226. o.

Katz, M. L. - Shapiro, C. (1985) Network Externalities, Competition, and Compatibility. The American Economic Review, 3., 424-440. o.

Kirby, K. - R. J. Herrnstein (1995) Preference Reversals Due to Myopic Discounting of Delayed Reward. Psychological Science, 2., 83-89. o.

Klemperer, P. (1990) How Broad Should the Scope of Patent Protection Be? RAND Journal of Economics, 1., 113-130. o.

La Porta, R. - Lopez-de-Silanes, F. - Shleifer, A. - Vishny, R. (1998) The Quality of Government. NBER Working Paper No. 6727.

Laibson, D. (1996) Hyperbolic Discount Functions, Undersaving and Saving Policy. NBER working paper No. 5635.

Laibson, D. (1997) Golden Eggs and Hyperbolic Discounting. Quarterly Journal of Economics, 2., 443-477. o.

Laibson, D. - Repetto, A. - Tobacman, J. (2007) Estimating Discount Functions with Consumption Choices over the Lifecycle. NBER working paper No. 13314

Lamoreaux, N. - Sokoloff, K. (2001) Market Trade in Patents and the Rise of a Class of Specialized Inventors in the $19^{\text {th }}$-Century United States. American Economic Review, 2., 39-44. o.

Lemos, N. (2007) An Introduction to the Theory of Knowledge. Cambridge University Press, Cambridge, UK

Lengyel Balázs (2012) Tudásalapú regionális fejlődés. L’Harmattan Kiadó, Budapest

Lengyel Imre - Fenyővári Zsolt - Nagy Benedek (2012) A közelség szerepének újraértelmezése az innovatív üzleti kapcsolatokban. Vezetéstudomány, 3., 19-29. o.

Lerner, J. - Tirole, J. (2002) Some Simple Economics of Open Source. The Journal of Industrial Economics, 2., 197-234. o.

Lippai László (2009) Az intertemporális diszkontálási folyamatok jelentősége a fogyasztói döntésekben. Közgazdasági Szemle, 7-8., 689-708. o.

Lippai László (2010) Fogyasztói önkontrollt igénylő döntések empirikus vizsgálata. Közgazdasági Szemle, 7-8., 700-714. o. 
Loewenstein, G. - Prelec, D. (1992) Anomalies in Intertemporal Choice: Evidence and an Interpretation. Quarterly Journal of Economics, 2., 573-597. o.

Loury, G. C. (1979) Market Structure and Innovation. The Quarterly Journal of Economics, 3., 395-410. o.

Machlup, F. (1958) An Economic Review of the Patent System. Washington D.C.: US Government Printing Office. Online: http://mises.org/document/1182/An-EconomicReview-of-the-Patent-System, letöltve: 2012. jún. 5.

Mackaay, E. (1999) On Property Rights and their Modification. In Fase, M. M. G. - W. Kanning, W. - Walker, D. A. (eds.) Economics, Welfare Policy and the History of Economic Thought - Essays in Honour of Arnold Heertje. Edward Elgar, Cheltenham, UK, 245-264. o.

Maskus, K. E. - Penubarti, M. (1995) How trade-related are intellectual property rights? Journal of International Economics, 39., 227-248. o.

Matsumura, T. - Matsushita, N. (2008) On patent licensing in spatial competition with endogenous location choice. Online: jww.iss.u-tokyo.ac.jp/ matsumur/LI.pdf, letöltve: 2012. aug. 29.

May, C. (2005) Between Commodification and "Openness": The Information Society and the Ownership of Knowledge. The Journal of Information, Law and Technology, Online: http://www2.warwick.ac.uk/fac/soc/law/elj/jilt/2005_2-3/may/, letöltve: 2008. szept. 7.

Menell, P. - Scotchmer S. (2007) Intellectual Property. In Polinsky. M. - Shavell, S. (eds.) Handbook of Law and Economics. Elsevier, Amsterdam. Preprint, online: http://papers.ssrn.com/sol3/papers.cfm? abstract_id=741424, letöltve: 2008. júl. 18.

Meyer Dietmar (1995) Az új növekedéselmélet. Vázlatos áttekintés. Közgazdasági Szemle, 4., 387-398. o.

Monore, P. - Taylor, R. (2010) Knowledge Diffusion and Innovation. Edward Elgar

Mulligan, C. B. (1996) A logical economist's argument against hyperbolic discounting. Working Paper, University of Chicago

Naghavi, A. (2007) Strategic Intellectual Property Rights Policy and North-South Technology Transfer. Review of World Economics, 1., 55-78. o.

NIPRCC (2011) Intellectual Property Rights Violation: A Report on Threats to United States Interests at Home and Abroad. Online: http://www.iprcenter.gov/reports/iprcenter-reports/IPR Center Threat Report and Survey.pdf/view, letöltve: 2012. július 19. 
Nordhaus, W. D. (1967) The Optimal Life of a Patent. Cowles Foundation Discussion Papers 241., New Haven

OECD (2005) Oslo Manual. Guidelines for Collecting and Interpreting Innovation Data (3rd ed.). OECD, Paris

Park, W. G. - Wagh, S. (2002) Index of Patent Rights, 2000 Updade. In Gwartney, J. Lawson, R. (eds.) Economic Freedom of the World Annual Report 2002. Chapter 2. Fraser Institute, Vancouver, BC, 33-42. o.

Park, W. G. - Lippoldt, D. C. (2003) The Impact of Trade-related Intellectual Property Rights on Trade and Foreign Direct Investment in Developing Countries. OECD Working Paper. online: http://www.oecd.org/dataoecd/59/46/2960051.pdf, letöltve: 2008. okt. 7.

Park, W. G. - Lippoldt, D. C. (2005) International Licensing and the Strengthening of Intellectual Property Rights in Developing Countries During the 1990s. OECD Economic Studies No. 40.

Park, W. G. - Lippoldt, D. C. (2008) Technology Transfer and the Economic Implications of the Strengthening of Intellectual Property Rights in Developing Countries. OECD Trade Policy Working Papers No. 62, OECD Publishing. doi:10.1787/244764462745

Park, W. G. (2008) International Patent Protection: 1960-2005. Research Policy, 4., 761766. o.

Phelps, E. S. - Pollak, R. A. (1968) On second-best national saving and game-equilibrium growth. Review of Economic Studies, 35., 185-199. o.

Polányi Mihály (1966) The Tacit Dimension. Routledge \& Kegan Paul, London

Poddar, S. - Sinha, U. B. (2004) On Patent Licensing in Spatial Competition. The Economic Record, 249., 208-218. o.

Putnam, J. (2008): The Law and Economics of International Intellectual Property: a Primer In Maskus, K. E. (ed.) Frontiers of Economics and Globalization 2, Intellectual Property, Growth and Trade. Elsevier, Amsterdam, 19-86. o.

Qiu, L. D. - Yu, H. (2010) Does the Protection of Foreign Intellectual Property Rights Stimulate Innovation in the US? Review of International Economics, 5., 882-895. o.

Rachlin, H. (2006) Notes on discounting. Journal of the Experimental Analysis of Behaviour, 3., 425-435. o.

Rafiquzzaman, M. (2002) The Impact of Patent Rights on International Trade: Evidence from Canade. Canadian Journal of Economics, 35., 307-330. o. 
Rapp, R. T. - Rozek, R. P. (1990) Benefits and Costs of Intellectual Property Protection in Developing Countries. Journal of World Trade, 24., 75-102. o.

Read, D. (2001) Is Time-Discounting Hyperbolic or Subadditive? Journal of Risk and Uncertainty, 1., 5-32. o.

Read, D. (2003) Intertemporal Choice. Working Paper. Internetcím: http://eprints.lse.ac.uk/ 22769/1/03058.pdf. letöltve: 2010. okt. 20.

Risch, M. (2008) Everything is Patentable. Tennessee Law Review, 75., 591-658. o.

Rogers, E. G. (2003) Diffusion of Innovations. 5th edition, Free Press, New York

Romer, P. (1990) Endogenous Technological Change. Journal of Political Economy, 98., S71-S102. o.

Saggi, K. (2002) Trade, Foreign Direct Investment, and International Technology Transfer: A Survey. The World Bank Research Observer, 2., 191-235. o.

Samuelson, P. A. (1937) A Note on Measurement of Utility. The Review of Economic Studies, 4., 155-161. o.

Scherer, F. M. (1972) Nordhaus' Theory of Optimal Patent Life: a Geometric Reinterpretation. American Economic Review, 62., 422-427. o.

Schreyögg, G. - Geiger, D. (2002) Knowledge, Narrations and Könnerschaft. Freie Universitaet Berlin, Institute für Management

Scotchmer, S. (1991) Standing on the Shoulders of Giants: Cumulative Research and the Patent Law. Journal of Economic Perspectives, 1., 29-41. o.

Smith, P. J. (1999) Are weak patent rights a barrier to U.S. exports? Journal of International Economics, 48., 151-177. o.

Stiglitz, J. (1999) Knowledge As a Global Public Good In Kaul, I. - Grunberg, I. - Stern, M. A. (eds) Global Public Goods. Oxford University Press, Oxford, UK

Stock, J. H. - Wright, J. H. - Yogo, M. (2002) A Survey of Weak Instruments and Weak Identification in Generalized Method of Moments. Journal of Business \& Economic Statistics, 4., 518-529.o.

Strotz, R. H. (1956) Myopia and Inconsistency in Dynamic Utility Maximization. The Review of Economic Studies, 3., 165-180. o.

Szabó Katalin (2012) Az invenciótól az innovációig. In Hámori Balázs - Szabó Katalin (szerk.) Innovációs verseny. Esélyek és korlátok. Aula kiadó, Budapest, 21-46. o.

Szabó Katalin - Hámori Balázs (2006) Információgazdaságtan. Akadémia Kiadó, Budapest 
Takalo, T. (1998) Innovatin and Imitation under Imperfect Patent Protection. Journal of Economics, 3., 229-241. o.

Takalo, T. (1999) Essays on the Economics of Intellectual Property Protection. Academic thesis, University of Helsinki. Online: http://ethesis.helsinki.fi/julkaisut/val/kansa/vk/ takalo/essayson.pdf, letöltve: 2009. szept. 10.

Taylor, M. S. (1993) 'Quality Ladders' and Ricardian Trade. Journal of International Economics, 34., 225-243. o.

Taylor, M. S. (1994) TRIPS, Trade and Growth. International Economic Review, 2., 361381. 0 .

Thaler, R. (1981) Some Empirical Evidence on Dynamic Inconsistency. Economic Letters, 3., 201-207. o.

Trope, Y. - Liberman, N. (2003) Temporal Construal Theory of Time-Dependent Preferences. In Brocas, I. - Carrillo J. D. (eds) The Psychology of Economic Decisions. Volume I. Oxford University Press, Oxford, 235-249. o.

UNIDO (2002) Industrial Development Report 2002/2003: Competing through Innovation and Learning. online: www.unido.org. Letöltve: 2011. okt. 30.

Varga Attila (2006) Térszerkezet, technológiai fejlödés és makrogazdasági növekedés. Habilitációs előadások 7. online: http://www.rphd.ktk.pte.hu/files/tiny_mce/File/ Kiadvanyok/Eloadasok/habil_varga_attila.pdf, letöltve: 2012. aug. 20.

Weber, M. (1979) Gazdaságtörténet. Közgazdasági és Jogi Könyvkiadó, Budapest

Witt, U. (2002) How Evolutionary is Schumpeter's Theory of Economic Development? Industry and Innovation, 1-2., 7-22. o.

Wright, B. D. (1983) The Economics of Invention Incentives: Patents, Prizes and Research Contracts. American Economic Review, 4., 691-707. o.

Wright, D. J. (1999) Optimal patent breadth and length with costly imitation. International Journal of Industrial Organisation, 3., 419-436. o.

Zahra, S. A. - George, G. (2002) Absorptive Capacity: A Review, Reconceptualization and Extention. Academy of Management Review, 2., 185-203. o.

Zigic, K. (1998) Intellectual property rights violations and spillovers in Norht-South trade. European Economic Review, 42., 1779-1799. o.

Zuniga, M. P. - Aboites, J. (2003) Patent reforms and pharmaceutical innovation: A crosscountry study using European data. Conference on innovation in honor of Keith Pavitt, November 13-15, Brighton, England 


\section{Mellékletek}

1. számú melléklet: Az optimális szabadalmi hossz kvázi-hiperbolikus diszkontálás esetén

1. Meghatározandó az innováció időpontja $\left(t_{I}\right)$. A tI időpontban végrehajtott innováció profitja:

$$
\Pi_{I}\left(t_{I}\right)=\int_{t_{I}}^{t_{I}+L} H_{0} \cdot e^{-\left(r_{e}-g\right) \cdot t} d t-I \cdot e^{-r_{e} t_{I}}
$$

Ahol L a szabadalmi védelem hossza, $H_{0}$ az első időszakban, mely időszakonként $g$ ütemben nő, $r_{e}$ az exponenciális kamatláb, $I$ a beruházás költsége.

A vállalatok közti verseny (szabadalmi verseny, patent race) eltünteti az innovációból származó profitot, tehát

$$
\Pi_{I}\left(t_{I}\right)=H_{0} \cdot \frac{1}{r_{e}-g} \cdot\left(1-e^{-\left(r_{e}-g\right) \cdot L}\right) \cdot e^{-\left(r_{e}-g\right) \cdot t_{I}}-I \cdot e^{-r_{e} \cdot t_{I}}=0,
$$

ahonnan meghatározható az innováció időpontja ${ }^{64}$ :

$$
t_{I}=\frac{1}{g} \ln \frac{I \cdot\left(r_{e}-g\right)}{H_{0} \cdot\left(1-e^{-\left(r_{e}-g\right) \cdot L}\right)} \cdot
$$

2. Meghatározható a szabadalmi védelem optimális hossza $(L)$. Ehhez elöször is fel kell írnunk a maximálandó társadalmi jólétet.

$$
W_{e}(L)=\int_{t_{I}}^{t_{I}+L}\left(H_{0}+J_{0}\right) \cdot e^{-\left(r_{e}-g\right) \cdot t} d t+\int_{t I+L}^{\infty}\left(H_{0}+K_{0}+J_{0}\right) \cdot e^{-\left(r_{e}-g\right) \cdot t} d t-I e^{-r_{e} \cdot t_{I}} .
$$

A kifejezést szétbontva az alábbi képlet adódik

$$
W_{e}(L)=\int_{t_{I}}^{t_{I}+L} J_{0} \cdot e^{-\left(r_{e}-g\right) \cdot t} d t+\int_{t I+L}^{\infty} J_{0} \cdot e^{-\left(r_{e}-g\right) \cdot t} d t+\int_{t I+L}^{\infty}\left(H_{0}+K_{0}\right) \cdot e^{-\left(r_{e}-g\right) \cdot t} d t+\int_{t_{I}}^{t_{I}+L} H_{0} \cdot e^{-\left(r_{e}-g\right) \cdot t} d t-I e^{-r_{e} \cdot t_{I}}
$$

A két utolsó tag valójában $\Pi_{I}\left(t_{I}\right)$, amiröl fentebb tettük fel, hogy zérus, ők tehát elhagyhatóak. Az első két tag, az innovációból származó extern hasznok a szabadalmi védelem időtartama alatt, illetve annak lejárta után, pedig összevonhatóak, így a maximalizálandó jólét

$$
W_{e}(L)=\int_{t_{I}}^{\infty} J_{0} \cdot e^{-\left(r_{e}-g\right) \cdot t} d t+\int_{t I+L}^{\infty}\left(H_{0}+K_{0}\right) \cdot e^{-\left(r_{e}-g\right) \cdot t} d t
$$

Elvégezve az integrálást, és egyszerübb alakra hozva:

$W_{e}(L)=\frac{J_{0} \cdot e^{-\left(r_{e}-g\right) \cdot t_{I}}}{r_{e}-g}+\frac{\left(H_{0}+K_{0}\right) \cdot e^{-\left(r_{e}-g\right) \cdot\left(t_{I}+L\right)}}{r_{e}-g}=\frac{1}{r_{e}-g} \cdot e^{-\left(r_{e}-g\right) \cdot t_{I}} \cdot\left[J_{0}+\left(H_{0}+K_{0}\right) \cdot e^{-\left(r_{e}-g\right) \cdot L}\right]$

A képletbe helyettesítsük be a nullprofit-feltételből adódó $t_{I}$-re kapott kifejezést. Ezután, néhány kiemelést elvégezve a maximalizálandó jólét

\footnotetext{
${ }^{64}$ Duffy $(2003,10$. o.) alapján
} 


$$
W_{e}(L)=\left(\frac{H_{0}}{I \cdot\left(r_{e}-g\right)}\right)^{\frac{r_{e}-g}{g}} \cdot \frac{1}{r_{e}-g} \cdot\left(1-e^{-\left(r_{e}-g\right) \cdot L}\right)^{\frac{r_{e}-g}{g}} \cdot\left(J_{0}+\left(H_{0}+K_{0}\right) \cdot e^{-\left(r_{e}-g\right) \cdot L}\right)
$$

Az egyszerüség kedvéért vezessünk be egy új paramétert az első (konstans) tag jelölésére:

$$
C_{e}=\left(\frac{H_{0}}{I \cdot\left(r_{e}-g\right)}\right)^{\frac{r_{e}-g}{g}}
$$

A jólét egyetlen befolyásoló változója a szabadalmi védelem hossza $(L)$. A jólét maximuma ott van, ahol az $L$-szerinti első derivált értéke zérus, tehát

$$
\begin{aligned}
\frac{d W_{e}(L)}{d L}=C_{e} & \cdot \frac{1}{r_{e}-g}\left\{\left[\left(\frac{\left(r_{e}-g\right)^{2} \cdot e^{-\left(r_{e}-g\right) \cdot L} \cdot\left(1-e^{-\left(r_{e}-g\right) \cdot L}\right)^{\frac{r_{e}-2 g}{g}}}{g}\right) \cdot\left(J_{0}+\left(H_{0}+K_{0}\right) \cdot e^{-\left(r_{e}-g\right)}\right)\right]+\right. \\
& \left.+\left[\left(\left(1-e^{-\left(r_{e}-g\right) \cdot L}\right)^{\frac{r_{e}-g}{g}}\right) \cdot\left(-\left(r_{e}-g\right) \cdot\left(H_{0}+K_{0}\right) \cdot e^{-\left(r_{e}-g\right) \cdot L}\right)\right]\right\}=0 .
\end{aligned}
$$

Vezessük be a $B=e^{-\left(r_{e}-g\right) \cdot L}$ jelölést! Egyszerüsítések és kiemelések után:

$$
\frac{d W_{e}(L)}{d L}=C_{e} \cdot(1-B)^{\frac{r_{e}-2 g}{g}} \cdot\left\{\left[\frac{r_{e}-g}{g} \cdot B \cdot\left(J_{0}+\left(H_{0}+K_{0}\right) \cdot B\right)\right]-\left[(1-B) \cdot B \cdot\left(H_{0}+K_{0}\right)\right]\right\}=0 \text {. }
$$

Mivel $r_{e}>g$, ha $L>0$, akkor az első két tag nem lehet 0 . A derivált értéke tehát csak akkor lehet nulla, ha az utolsó, kapcsos zárójelbeli tag 0:

$$
\begin{aligned}
& \frac{r_{e}-g}{g} \cdot B \cdot\left(J_{0}+\left(H_{0}+K_{0}\right) \cdot B\right)-(1-B) \cdot B \cdot\left(H_{0}+K_{0}\right)=0 \\
& \frac{r_{e}-g}{g} \cdot J_{0}+\left(H_{0}+K_{0}\right) \cdot\left(\frac{\left(r_{e}-g\right) \cdot B}{g}-\frac{(1-B) \cdot g}{g}\right)=0,
\end{aligned}
$$

ahonnan

Q.E.D. ${ }^{65}$

$$
\frac{J_{0}}{H_{0}+K_{0}}=\frac{g-r_{e} \cdot B}{r_{e}-g}
$$

3. Az innováció (4) szerinti időpontja akkor tolódik az 1. időszaknál korábbra, ha

$$
\begin{gathered}
t_{I}=\frac{1}{g} \ln \frac{I \cdot\left(r_{e}-g\right)}{H_{0} \cdot\left(1-e^{-\left(r_{e}-g\right) \cdot L}\right)}<1 \\
\frac{I \cdot\left(r_{e}-g\right)}{H_{0} \cdot\left(1-e^{-\left(r_{e}-g\right) \cdot L}\right)}<e^{g} \\
\frac{I}{H_{0}} \cdot\left(r_{e}-g\right)<e^{g}-e^{g} \cdot e^{-\left(r_{e}-g\right) \cdot L} \\
\frac{e^{g}}{e^{g}-\frac{I}{H_{0}} \cdot\left(r_{e}-g\right)}<e^{\left(r_{e}-g\right) \cdot L},
\end{gathered}
$$

Ahonnan adódik, hogy

\footnotetext{
${ }^{65}$ Duffy $(2003,34-35$. o.) nyomán
} 


$$
L>\frac{1}{r_{e}-g} \cdot \ln \frac{e^{g}}{e^{g}-\frac{I}{H_{0}}\left(r_{e}-g\right)} .
$$

Vizsgáljuk meg, mikor lesz ez az idő nagyobb, mint a minimálisan optimális szabadalmi idő, illetve az optimális szabadalmi idő! Duffy tanulmányából tudjuk, hogy az optimális szabadalmi idő mindig nagyobb, mint a minimálisan optimális, ha $\frac{J_{0}}{H_{0}+K_{0}}>0$, ha tehát ez a fönti szabadalmi védelmi idö hosszabb az optimálisnál, akkor biztosan hosszabb a minimálisan optimális szabadalmi időnél is. Nézzük meg tehát, hogy mikor lehet

$$
\frac{1}{r_{e}-g} \cdot \ln \frac{e^{g}}{e^{g}-\frac{I}{H_{0}}\left(r_{e}-g\right)}>\frac{1}{r_{e}-g} \cdot \ln \frac{r}{g \cdot\left(1-\frac{J_{0}}{H_{0}+K_{0}} \frac{r_{e}-g}{g}\right)},
$$

ahol az egyenlőtlenség jobb oldala (6) alapján az optimális szabadalmi élettartam!

ahonnan

$$
\frac{e^{g}}{e^{g}-\frac{I}{H_{0}}\left(r_{e}-g\right)}>\frac{r}{g \cdot\left(1-\frac{J_{0}}{H_{0}+K_{0}} \frac{r_{e}-g}{g}\right)},
$$

$$
\frac{I}{H_{0}}>\frac{e^{g}}{r_{e}} \cdot\left(1+\frac{J_{0}}{H_{0}+K_{0}}\right)
$$

A vállalatok - szabadalmi versenyböl következő - nullprofit-feltételéből kiindulva adhatunk egy alsó korlátot $I / H_{0}$ értékére, mivel $I$ legföljebb $L^{*}$-szerese lehet $H_{0}$-nak. ekkor

$$
\frac{I}{H_{0}}>L^{*}>\frac{e^{g}}{r_{e}} \cdot\left(1+\frac{J_{0}}{H_{0}+K_{0}}\right) \text {. }
$$

Ez pedig a Duffy által használt $r_{e}$ és $g$ értékekre tetszőleges társadalmi többlet-hányad esetében fennáll.

4. A kvázi-hiperbolikus diszkontálás bevezetésével megváltozik az alkalmazandó, maximalizálandó társadalmi jóléti függvény:

$W_{h}(L)=\int_{t_{I}}^{t_{I}+L} J_{0} \cdot \beta \cdot e^{-\left(r_{h}-g\right) \cdot t} d t+\int_{t I+L}^{\infty} J_{0} \cdot \beta \cdot e^{-\left(r_{h}-g\right) \cdot t} d t+\int_{t I+L}^{\infty}\left(H_{0}+K_{0}\right) \cdot \beta \cdot e^{-\left(r_{h}-g\right) \cdot t} d t+\int_{t_{I}}^{t_{I}+L} H_{0} \cdot e^{-\left(r_{e}-g\right) \cdot t} d t-I e^{-r_{e} \cdot t_{I}}$

ahol a képletben megjelenik a kvázi-hiperbolikus diszkontálás $0<\beta<1$ paramétere, és a kamatláb $0<g<r_{h}<r_{e}<1$. Mivel még mindig áll a vállalatokra vonatkozó nullprofit feltétel, az utolsó két tag ismét nulla, az első két tag pedig összevonható:

$$
W_{h}(L)=\int_{t_{I}}^{\infty} J_{0} \cdot \beta \cdot e^{-\left(r_{h}-g\right) \cdot t} d t+\int_{t I+L}^{\infty}\left(H_{0}+K_{0}\right) \cdot \beta \cdot e^{-\left(r_{h}-g\right) \cdot t} d t .
$$

Az integrálást elvégezve és egyszerübb alakra hozva:

$$
W_{h}(L)=\beta \cdot \frac{1}{r_{h}-g} \cdot e^{-\left(r_{h}-g\right) \cdot t_{I}} \cdot\left[J_{0}+\left(H_{0}+K_{0}\right) \cdot e^{-\left(r_{h}-g\right) \cdot L}\right] .
$$

A képletbe ismét helyettesítsük be a nullprofit-feltételböl $t_{I}$-re kapott kifejezést. Ezután, néhány kiemelést elvégezve a maximalizálandó jólét 


$$
W_{h}(L)=\left(\frac{H_{0}}{I \cdot\left(r_{e}-g\right)}\right)^{\frac{r_{h}-g}{g}} \cdot \frac{1}{r_{h}-g} \cdot \beta \cdot\left(1-e^{-\left(r_{e}-g\right) \cdot L}\right)^{r_{h}-g} \cdot\left(J_{0}+\left(H_{0}+K_{0}\right) \cdot e^{-\left(r_{h}-g\right) \cdot L}\right)
$$

A könnyebb kezelhetőség miatt ismét vezessünk be egy új paramétert az első (konstans) tag jelölésére:

$$
C_{h}=\left(\frac{H_{0}}{I \cdot\left(r_{e}-g\right)}\right)^{\frac{r_{h}-g}{g}}
$$

A jólét egyetlen befolyásoló változója ismét a szabadalmi védelem hossza $(L)$. A jólét maximuma ott van, ahol az $L$-szerinti első derivált értéke zérus, tehát

$$
\begin{aligned}
\frac{d W_{h}(L)}{d L}=C_{h} & \cdot \frac{1}{r_{e}-g} \cdot \beta \cdot\left\{\left(\left[\frac{\left(r_{e}-g\right) \cdot\left(r_{h}-g\right) \cdot e^{-\left(r_{e}-g\right) \cdot L} \cdot\left(1-e^{-\left(r_{e}-g\right) \cdot L}\right)^{\frac{r_{h}-2 g}{g}}}{g}\right) \cdot\left(J_{0}+\left(H_{0}+K_{0}\right) \cdot e^{-\left(r_{h}-g\right)}\right)\right]+\right. \\
& \left.+\left[\left(\left(1-e^{-\left(r_{e}-g\right) \cdot L}\right)^{\frac{r_{h}-g}{g}}\right) \cdot\left(-\left(r_{h}-g\right) \cdot\left(H_{0}+K_{0}\right) \cdot e^{-\left(r_{h}-g\right) \cdot L}\right)\right]\right\}=0 .
\end{aligned}
$$

Használjuk ismét a $B=e^{-\left(r_{e}-g\right) \cdot L}$ jelölést, továbbá vezessünk be egy $B_{h}=e^{-\left(r_{h}-g\right) \cdot L}$ jelölést is! Egyszerüsítések és kiemelések után:

$$
\frac{d W_{h}(L)}{d L}=C_{h} \cdot(1-B)^{\frac{r_{h}-2 g}{g}} \cdot \beta \cdot \frac{r_{h}-g}{r_{e}-g} \cdot\left\{\left[\frac{r_{e}-g}{g} \cdot B \cdot\left(J_{0}+\left(H_{0}+K_{0}\right) \cdot B_{h}\right)\right]-\left[(1-B) \cdot B_{h} \cdot\left(H_{0}+K_{0}\right)\right]\right\}=0
$$

Mivel $r_{e}>\mathrm{r}_{\mathrm{h}}>g$, ha $L>0$, akkor az első két tag nem lehet 0 , és az újonnan megjelent harmadik és negyedik tag sem, a feltételekből következően. A derivált értéke tehát ismét csak akkor lehet nulla, ha az utolsó, kapcsos zárójelbeli tag 0:

$$
\begin{aligned}
& \frac{r_{e}-g}{g} \cdot B \cdot\left(J_{0}+\left(H_{0}+K_{0}\right) \cdot B_{h}\right)-(1-B) \cdot B_{h} \cdot\left(H_{0}+K_{0}\right)=0 \\
& \frac{r_{e}-g}{g} \cdot J_{0} \cdot B+\left(H_{0}+K_{0}\right) \cdot B_{h} \cdot\left(\frac{\left(r_{e}-g\right) \cdot B}{g}-\frac{(1-B) \cdot g}{g}\right)=0,
\end{aligned}
$$

ahonnan

$$
\frac{J_{0}}{H_{0}+K_{0}}=\frac{g-r_{e} \cdot B}{r_{e}-g} \cdot \frac{B_{h}}{B}
$$

Q.E.D.

5. A következő jelöléseket használjuk: $B=e^{-\left(r_{e}-g\right) L}$ és $B_{h}=e^{-\left(r_{h}-g\right) L}$. Legyen $L^{*}$ olyan, hogy $B^{*}=e^{-\left(r_{e}-g\right) L^{*}}$ esetén teljesül, hogy

$$
\frac{J_{0}}{H_{0}+K_{0}}=\frac{g-r_{e} \cdot B^{*}}{r_{e}-g}
$$

Ugyanakkor legyen $L^{* * *}$ olyan, hogy $B^{* * *}=e^{-\left(r_{e}-g\right) L^{* * *}}$, illetve $B_{h}^{* * *}=e^{-\left(r_{h}-g\right) L^{* * *}}$ esetén teljesül, hogy 


$$
\frac{J_{0}}{H_{0}+K_{0}}=\frac{\left(g-r_{e} \cdot B^{* *}\right)}{r_{e}-g} \cdot \frac{B_{h}^{* *}}{B^{* *}}
$$

Az $L^{*}$ és az $L^{* *}$ viszonyát vizsgáljuk. Mivel $\frac{J_{0}}{H_{0}+K_{0}}$ értéke független az $L$ értékének megválasztásától, így fennáll a

$$
\frac{g-r_{e} \cdot B^{*}}{r_{e}-g}=\frac{g-r_{e} \cdot B^{* *}}{r_{e}-g} \cdot \frac{B_{h}^{* *}}{B^{* *}}
$$

egyenlőség.

Tekintve, hogy $\frac{B_{h}^{* *}}{B^{* *}}$ mindenképpen nagyobb egynél, hisz $\frac{B_{h}^{* *}}{B^{* *}}=e^{\left(r_{e}-r_{h}\right) L^{* *}}$, így fennáll a következő egyenlőtlenség:

vagy egyszerübben

$$
g-r_{e} \cdot B^{*}=\left(g-r_{e} \cdot B^{* *}\right) \frac{B_{h}^{* *}}{B^{* *}}>\left(g-r_{e} \cdot B^{* * *}\right) \cdot 1,
$$

$$
g-r_{e} \cdot B^{*}>g-r_{e} \cdot B^{* *}
$$

ahonnan

$$
\begin{aligned}
-r_{e} \cdot B^{*} & >-r_{e} \cdot B^{* *} \\
B^{*} & <B^{* * *}
\end{aligned}
$$

Azt kapjuk tehát, hogy $e^{-\left(r_{e}-g\right) L^{*}}<e^{-\left(r_{e}-g\right) L^{* *}}$, ami csak úgy adódhat, ha a jobb oldali kitevő nagyobb mint a bal oldali, azaz

$$
-\left(r_{e}-g\right) L^{*}<-\left(r_{e}-g\right) L^{* *}
$$

ahonnan

$$
L^{*}>L^{* *}
$$

Összefoglalva tehát azt kapjuk, hogy az exponenciális egyenletet igazzá tevő $L^{*}$ mindenképpen nagyobb, mint a kvázi-hiperbolikus egyenletet igazzá tevő $L^{* *}$. 
2. számú melléklet: A szabadalmi védelmi index összetevői

(Park - Lippoldt, 2008, 33. o. és Ginarte - Park, 1997 alapján)

1.) Nemzetközi egyezményekben való tagság

- Párizsi Uniós Egyezmény

- Szabadalmi Együttműködési Szerződés

- Növényfajták oltalmára létesült nemzetközi egyezmény

- Budapesti Szerződés

- Szellemi Tulajdonjogok Kereskedelmi Vonatkozásairól Szóló Egyezmény (TRIPS)

(Ezek közül ahány egyezménynek aláírója az adott ország, annyiszor 1/5 pont, összesen maximum 1 pont a kategóriára.)

2.) Hatáskör

- gyógyszerek szabadalmaztathatósága

- vegyszerek szabadalmaztathatósága

- élelmiszerek szabadalmaztathatósága

- sebészeti eszközök szabadalmaztathatósága

- mikroorganizmusok szabadalmaztathatósága

- hasznossági modellek (utility model) szabadalmaztathatósága

- szoftverek szabadalmaztathatósága

- növény- és állatfajták szabadalmaztathatósága

(A fentiek közül ahány védelem elérhetö, annyiszor 1/8 pont, összesen maximum 1 pont a kategóriában)

3.) Szabadalmakra vonatkozó megkötések

- „elérhetőségi” megkötések

- kötelező licencbe adás

- szabadalom visszavonása

(Ahány megkötés ezek közül létezik az adott ország szabályozásában, annyiszor 1/3 pont) 
4.) Kikényszerítés, végrehajtás

- ideiglenes tiltó intézkedések

- kiegészítő szabadalom-sértés

- bizonyítási kényszer megfordítása

(Ahány módszer a fentiek közül létezik az adott ország szabályozásában, annyiszor 1/3 pont)

5.) Védelem időtartama.

(0-1 terjedö szám annak függvényében, hogy az adott országban adható szabadalmi védelem a benyújtástól számított 20 év, illetve a szabadalom odaitélésétöl számitott 17 év mekkora hányada.)

Mind az 5 kategóriában maximum 1 pont adható, a szabadalmi védelem erősségét jellemző Ginarte-Park index ennek az 5 részpontszámnak az összege. 
A csoportosítás SITC Rev. 2 kódok alapján történik UNIDO (2004) szerint

High Technology: 524, 54,

$712,716,718,75,761,764,771,774,776,778,792$, $871,874,881$.

Medium Technology: 266, 267,

$512,513,533,552,553,56,57,58,591,598$,

$653,671,672,678$,

711, 713, 714, 72, 73, 74, 762, 763, 772, 773, 775, 78, 791, 793,

$81,872,882,883,884,885$,

95.

Low Technology: $\quad 61,642,651,652,654,655,656,657,658,659,665,666,673,674$, $675,676,677,679,69$,

$82,83,84,85,893,894,895,897,898,899$. 
4. számú melléklet: A vizsgálatban részt vevő országok

\begin{tabular}{|c|c|c|c|c|c|c|c|c|}
\hline No. & $\begin{array}{l}\text { WB } \\
\text { code }\end{array}$ & $\begin{array}{c}\text { Országnév } \\
\text { (OECD tagság kezdete, ha } \\
\text { exportőr, WTO tagság } \\
\text { kezdete, ha importőr) }\end{array}$ & Jelölés & $\begin{array}{l}\text { IPR } \\
\text { '95 }\end{array}$ & $\begin{array}{l}\text { IPR } \\
\text { '00 }\end{array}$ & $\begin{array}{l}\text { IPR } \\
\text { '05 }\end{array}$ & $\begin{array}{l}\text { Jövedelmi } \\
\text { szint '95 * }\end{array}$ & $\begin{array}{l}\text { Jövedelmi } \\
\text { szint '00 * }\end{array}$ \\
\hline \multicolumn{9}{|c|}{ Exportőrök } \\
\hline 1 & 36 & Ausztrália (1961) & $A U$ & 4,17 & 4,17 & 4,17 & 4 & 4 \\
\hline 2 & 40 & Ausztria (1961) & AT & 4,21 & 4,33 & 4,33 & 4 & 4 \\
\hline 3 & 56 & Belgium (1961) & BE & 4,54 & 4,67 & 4,67 & 4 & 4 \\
\hline 4 & 124 & Kanada (1961) & $\mathrm{CA}$ & 4,34 & 4,67 & 4,67 & 4 & 4 \\
\hline 5 & 152 & Chile (2010) & $\mathrm{CL}$ & 3,91 & 4,28 & 4,28 & 3 & 3 \\
\hline 6 & 203 & Csehország (1995) & CZ & 2,96 & 3,21 & 4,33 & 3 & 3 \\
\hline 7 & 208 & Dánia (1969) & DK & 4,54 & 4,67 & 4,67 & 4 & 4 \\
\hline 8 & 246 & Finnország (1961) & $\mathrm{FI}$ & 4,42 & 4,54 & 4,67 & 4 & 4 \\
\hline 9 & 251 & Franciaország (1961) & FR & 4,54 & 4,67 & 4,67 & 4 & 4 \\
\hline 10 & 276 & Németország (1961) & $\mathrm{DE}$ & 4,17 & 4,50 & 4,50 & 4 & 4 \\
\hline 11 & 300 & Görögország (1961) & GR & 3,47 & 3,97 & 4,30 & 3 & 4 \\
\hline 12 & 348 & Magyarország (1969) & $\mathrm{HU}$ & 4,04 & 4,04 & 4,50 & 3 & 3 \\
\hline 13 & 352 & Izland (1961) & IS & 2,68 & 3,38 & 3,51 & 4 & 4 \\
\hline 14 & 372 & Írország (1961) & IE & 4,14 & 4,67 & 4,67 & 4 & 4 \\
\hline 15 & 376 & Izrael (2010) & IL & 3,14 & 4,13 & 4,13 & 4 & 4 \\
\hline 16 & 381 & Olaszország (1962) & IT & 4,33 & 4,67 & 4,67 & 4 & 4 \\
\hline 17 & 392 & Japán (1964) & JP & 4,42 & 4,67 & 4,67 & 4 & 4 \\
\hline 18 & 442 & Luxemburg (1961) & LU & 3,89 & 4,14 & 4,14 & 4 & 4 \\
\hline 19 & 484 & Mexikó (1994) & MX & 3,14 & 3,68 & 3,88 & 3 & 3 \\
\hline 20 & 528 & Hollandia (1961) & NL & 4,54 & 4,67 & 4,67 & 4 & 4 \\
\hline 21 & 554 & Új-Zéland (1973) & NZ & 4,01 & 4,01 & 4,01 & 4 & 4 \\
\hline 22 & 579 & Norvégia (1961) & $\mathrm{NO}$ & 4,00 & 4,13 & 4,29 & 4 & 4 \\
\hline 23 & 616 & Lengyelország (1996) & PL & 3,46 & 3,92 & 4,21 & 2 & 3 \\
\hline 24 & 620 & Portugália (1961) & PT & 3,47 & 4,13 & 4,50 & 4 & 4 \\
\hline 25 & 410 & Korea (1996) & $\mathrm{KR}$ & 3,89 & 4,13 & 4,33 & 4 & 3 \\
\hline 26 & 703 & Szlovákia (2000) & SK & 2,96 & 2,96 & 4,21 & 2 & 3 \\
\hline 27 & 724 & Spanyolország (1961) & ES & 4,21 & 4,33 & 4,33 & 4 & 4 \\
\hline 28 & 752 & Svédország (1961) & SE & 4,42 & 4,54 & 4,54 & 4 & 4 \\
\hline 29 & 757 & Svájc (1961) & $\mathrm{CH}$ & 4,21 & 4,33 & 4,33 & 4 & 4 \\
\hline 30 & 792 & Törökország (1961) & TR & 2,65 & 4,01 & 4,01 & 2 & 3 \\
\hline 31 & 842 & USA (1961) & US & 4,88 & 4,88 & 4,88 & 4 & 4 \\
\hline 32 & 826 & UK (1961) & GB & 4,54 & 4,54 & 4,54 & 4 & 4 \\
\hline
\end{tabular}




\begin{tabular}{|c|c|c|c|c|c|c|c|c|}
\hline \multicolumn{9}{|c|}{ Importörök } \\
\hline 1 & 24 & Angola (1996) & $\mathrm{AO}$ & 0,88 & 1,08 & 1,20 & 1 & 1 \\
\hline 2 & 32 & Argentína (1995) & AR & 2,73 & 3,98 & 3,98 & 3 & 3 \\
\hline 3 & 50 & Bangladesh (1995) & BD & 1,87 & 1,87 & 1,87 & 1 & 1 \\
\hline 4 & 204 & Benin (1996) & BJ & 1,78 & 2,10 & 2,93 & 1 & 1 \\
\hline 5 & 68 & Bolívia (1995) & $\mathrm{BO}$ & 2,73 & 3,43 & 3,43 & 2 & 2 \\
\hline 6 & 72 & Botswana (1995) & BW & 2,08 & 3,32 & 3,52 & 2 & 3 \\
\hline 7 & 76 & Brazil (1995) & BR & 1,48 & 3,59 & 3,59 & 3 & 3 \\
\hline 8 & 100 & Bulgária (1996) & $B G$ & 3,23 & 4,42 & 4,54 & 2 & 2 \\
\hline 9 & 854 & Burkina Faso (1995) & $\mathrm{BF}$ & 0,20 & 0,20 & 2,93 & 1 & 1 \\
\hline 10 & 108 & Burundi (1995) & $\mathrm{BI}$ & 2,15 & 2,15 & 2,15 & 1 & 1 \\
\hline 11 & 120 & Kamerun (1995) & $\mathrm{CM}$ & 2,10 & 2,23 & 3,06 & 1 & 1 \\
\hline 12 & 140 & Közép-Afrikai Közt. (1995) & CF & 1,98 & 2,10 & 2,93 & 1 & 1 \\
\hline 13 & 148 & Csád (1996) & TD & 1,78 & 2,10 & 2,93 & 1 & 1 \\
\hline 14 & 156 & Kína (2001) & $\mathrm{CN}$ & 2,12 & 3,09 & 4,08 & 1 & 2 \\
\hline 15 & 344 & Hong Kong (1995) & HK & 2,90 & 3,81 & 3,81 & 4 & 4 \\
\hline 16 & 170 & Kolumbia (1995) & $\mathrm{CO}$ & 2,74 & 3,59 & 3,72 & 2 & 2 \\
\hline 17 & 178 & Kongó, Rep. (1997) & CG & 1,90 & 2,23 & 3,06 & 1 & 1 \\
\hline 18 & 188 & Costa Rica (1995) & CR & 1,56 & 2,89 & 2,89 & 2 & 3 \\
\hline 19 & 384 & Elefántcsontpart (1995) & $\mathrm{Cl}$ & 1,90 & 2,36 & 3,06 & 1 & 1 \\
\hline 20 & 196 & Ciprus (1995) & $\mathrm{CY}$ & 2,78 & 3,48 & 3,48 & 4 & 4 \\
\hline 21 & 180 & Zaire (1997) & $C D$ & 1,58 & 1,78 & 2,23 & 1 & 1 \\
\hline 22 & 214 & Dominikai Közt. (1995) & DO & 2,32 & 2,45 & 2,82 & 2 & 2 \\
\hline 23 & 218 & Equador (1996) & EC & 2,04 & 3,73 & 3,73 & 2 & 2 \\
\hline 24 & 818 & Egyiptom (1995) & EG & 1,73 & 1,86 & 2,77 & 2 & 2 \\
\hline 25 & 222 & El Salvador (1995) & SV & 3,23 & 3,36 & 3,48 & 2 & 2 \\
\hline 26 & 242 & Fiji (1996) & FJ & 2,20 & 2,40 & 2,40 & 2 & 2 \\
\hline 27 & 266 & Gabon (1995) & GA & 2,10 & 2,23 & 3,06 & 3 & 3 \\
\hline 28 & 288 & Ghana (1995) & $\mathrm{GH}$ & 2,83 & 3,15 & 3,35 & 1 & 1 \\
\hline 29 & 308 & Grenada (1996) & GD & 1,76 & 2,48 & 3,02 & 2 & 3 \\
\hline 30 & 320 & Guatemala (1995) & GT & 1,08 & 1,28 & 3,15 & 2 & 2 \\
\hline 31 & 328 & Guyana (1995) & GY & 1,13 & 1,33 & 1,78 & 1 & 2 \\
\hline 32 & 332 & Haiti (1996) & HT & 2,58 & 2,90 & 2,90 & 1 & 1 \\
\hline 33 & 340 & Honduras (1995) & $\mathrm{HN}$ & 1,90 & 2,86 & 2,98 & 1 & 2 \\
\hline 34 & 699 & India (1995) & IN & 1,23 & 2,27 & 3,76 & 1 & 1 \\
\hline 35 & 360 & Indonézia (1995) & ID & 1,56 & 2,47 & 2,77 & 2 & 1 \\
\hline 36 & 388 & Jamaika (1995) & JM & 2,86 & 3,06 & 3,36 & 2 & 2 \\
\hline 37 & 400 & Jordánia (2000) & $\mathrm{JO}$ & 1,08 & 3,03 & 3,43 & 2 & 2 \\
\hline 38 & 404 & Kenya (1995) & KE & 2,43 & 2,88 & 3,22 & 1 & 1 \\
\hline 39 & 440 & Litvánia (2001) & LT & 2,69 & 3,48 & 4,00 & 2 & 2 \\
\hline 40 & 450 & Madagaszkár (1995) & MG & 1,85 & 2,31 & 2,31 & 1 & 1 \\
\hline 41 & 454 & Malawi (1995) & MW & 2,03 & 2,15 & 2,15 & 1 & 1 \\
\hline 42 & 458 & Malaysia (1995) & MY & 2,70 & 3,03 & 3,48 & 3 & 3 \\
\hline
\end{tabular}




\begin{tabular}{|c|c|c|c|c|c|c|c|c|}
\hline 43 & 466 & Mali (1995) & ML & 1,98 & 2,10 & 2,93 & 1 & 1 \\
\hline 44 & 470 & Málta (1995) & MT & 1,60 & 3,18 & 3,48 & 3 & 4 \\
\hline 45 & 478 & Mauritánia (1995) & MR & 1,98 & 2,43 & 3,27 & 1 & 1 \\
\hline 46 & 480 & Mauríciusz (1995) & MU & 1,93 & 1,93 & 2,57 & 3 & 3 \\
\hline 47 & 504 & Marokkó (1995) & MA & 1,78 & 3,06 & 3,52 & 2 & 2 \\
\hline 48 & 508 & Mozambik (1995) & MZ & 0,20 & 1,06 & 2,52 & 1 & 1 \\
\hline 49 & 104 & Burma (1995) & MM & 0,20 & 0,20 & 0,20 & 1 & 1 \\
\hline 50 & 524 & Nepál (2004) & NP & 1,79 & 1,79 & 2,19 & 1 & 1 \\
\hline 51 & 558 & Nicaragua (1995) & $\mathrm{NI}$ & 1,12 & 2,16 & 2,97 & 1 & 1 \\
\hline 52 & 562 & Niger (1996) & $\mathrm{NE}$ & 1,78 & 2,10 & 2,93 & 1 & 1 \\
\hline 53 & 566 & Nigéria (1995) & NG & 2,86 & 2,86 & 3,18 & 1 & 1 \\
\hline 54 & 586 & Pakisztán (1995) & PK & 1,38 & 2,20 & 2,40 & 1 & 1 \\
\hline 55 & 591 & Panama (1997) & PA & 1,46 & 3,64 & 3,64 & 2 & 3 \\
\hline 56 & 598 & Pápua-Újguinea (1996) & $P G$ & 0,10 & 1,40 & 1,60 & 2 & 2 \\
\hline 57 & 600 & Paraguay (1995) & PY & 1,53 & 2,39 & 2,89 & 2 & 2 \\
\hline 58 & 604 & Peru (1995) & PE & 2,73 & 3,32 & 3,32 & 2 & 2 \\
\hline 59 & 608 & Fülöp-szk. (1995) & $\mathrm{PH}$ & 2,56 & 3,98 & 4,18 & 2 & 2 \\
\hline 60 & 642 & Románia (1995) & $\mathrm{RO}$ & 3,52 & 3,72 & 4,17 & 2 & 2 \\
\hline 61 & 646 & Ruanda (1996) & RW & 1,95 & 2,28 & 2,28 & 1 & 1 \\
\hline 62 & 682 & Szaúd-Arábia (2005) & SA & 1,83 & 1,83 & 2,98 & 3 & 3 \\
\hline 63 & 686 & Szenegál (1995) & SN & 1,98 & 2,10 & 2,93 & 1 & 1 \\
\hline 64 & 694 & Sierra Leone (1995) & $\mathrm{SL}$ & 2,45 & 2,98 & 2,98 & 1 & 1 \\
\hline 65 & 702 & Szingapúr (1995) & SG & 3,88 & 4,01 & 4,21 & 4 & 4 \\
\hline 66 & 710 & Dél-Afrikai Közt. (1995) & $\mathrm{ZA}$ & 3,39 & 4,25 & 4,25 & 3 & 3 \\
\hline 67 & 144 & Sri Lanka (1995) & LK & 2,98 & 3,11 & 3,11 & 1 & 2 \\
\hline 68 & 748 & Szváziföld (1995) & SZ & 1,98 & 2,43 & 2,43 & 2 & 2 \\
\hline 69 & 764 & Thaiföld (1995) & $\mathrm{TH}$ & 2,41 & 2,53 & 2,66 & 2 & 2 \\
\hline 70 & 768 & Togo (1995) & TG & 1,98 & 2,10 & 2,93 & 1 & 1 \\
\hline 71 & 780 & Trinidad és Tobago (1995) & TT & 2,33 & 3,63 & 3,75 & 3 & 3 \\
\hline 72 & 788 & Tunézia (1995) & $\mathrm{TN}$ & 1,65 & 2,32 & 3,25 & 2 & 2 \\
\hline 73 & 800 & Uganda (1995) & UG & 2,85 & 2,98 & 2,98 & 1 & 1 \\
\hline 74 & 804 & Ukrajna (2008) & UA & 3,68 & 3,68 & 3,68 & 2 & 1 \\
\hline 75 & 834 & Tanzánia (1995) & $\mathrm{TZ}$ & 2,32 & 2,64 & 2,64 & 1 & 1 \\
\hline 76 & 858 & Uruguay (1995) & UY & 2,07 & 2,27 & 3,39 & 3 & 3 \\
\hline 77 & 862 & Venezuela (1995) & VE & 2,82 & 3,32 & 3,32 & 2 & 3 \\
\hline 78 & 704 & Vietnam (2007) & VN & 2,90 & 2,90 & 3,03 & 1 & 1 \\
\hline 79 & 894 & Zambia (1995) & ZM & 1,62 & 1,74 & 1,94 & 1 & 1 \\
\hline 80 & 716 & Zimbabwe (1995) & ZW & 2,28 & 2,60 & 2,60 & 1 & 1 \\
\hline
\end{tabular}

Forrás: Walter G. Park honlapja, www.american.edu/cas/faculty/wgp.cfm, és www.worldbank.org

* a jövedelmi csoportok esetében 1 - Low income, 2 - Lower-middle income, 3 - Upper middle income, 4 - High income 